FERNANDO GIRARDI DE ABREU

ANÁLISE DA INFLUÊNCIA DA DISTRIBUIÇÃO TEMPORAL DAS CHUVAS INTENSAS E DE CENÁRIOS DE USO E OCUPAÇÃO DO SOLO NA QUANTIFICAÇÃO DOS PREJUÍZOS ECONÔMICOS DIRETOS PROVOCADOS PELAS INUNDAÇÕES URBANAS

\author{
VERSÃO CORRIGIDA \\ SÃO CARLOS - SP \\ 2013
}




\section{FERNANDO GIRARDI DE ABREU}

Análise da influência da distribuição temporal das chuvas intensas e de cenários de uso e ocupação do solo na quantificação dos prejuízos econômicos diretos provocados

pelas inundações urbanas

Dissertação apresentada à Escola de Engenharia de São Carlos, da Universidade de São Paulo, como parte dos requisitos para obtenção do título de Mestre em Ciências: Engenharia Hidráulica e Saneamento

Orientador: Prof. Dr. João Luiz Boccia Brandão 
AUTORIZO A REPRODUÇÃO TOTAL OU PARCIAL DESTE TRABALHO, POR QUALQUER MEIO CONVENCIONAL OU ELETRÔNICO, PARA FINS DE ESTUDO E PESQUISA, DESDE QUE CITADA A FONTE.

\footnotetext{
Abreu, Fernando Girardi de
A162a Análise da influência da distribuição temporal das chuvas intensas e de cenários de uso e ocupação do solo na quantificação dos prejuízos econômicos diretos provocados pelas inundações urbanas / Fernando Girardi de Abreu; orientador João Luiz Boccia Brandão. São Carlos, 2013.

Dissertação (Mestrado) - Programa de Pós-Graduação e Área de Concentração em Hidráulica e Saneamento - Escola de Engenharia de São Carlos da Universidade de São Paulo, 2013.
}

1. inundações urbanas. 2. distribuição temporal de chuvas. 3. prejuízos econômicos. I. Título. 
Candidato: Bacharel FERNANDO GIRARDI DE ABREU.

Título da dissertação: "Análise da influência da distribuição temporal das chuvas intensas e de cenários de uso e ocupação do solo na quantificação dos prejuízos econômicos diretos provocados pelas inundações urbanas".

Data da defesa: $18 / 10 / 2013$

\section{Comissão Julgadora:}

Prof. Dr. João Luiz Boccia Brandão (Orientador)

(Escola de Engenharia de São Carlos/EESC)

Prof. Associado Rodrigo de Melo Porto

(Escola de Engenharia de São Carlos/EESC)

Prof. Dr. Jefferson Nascimento de Oliveira
Resultado:
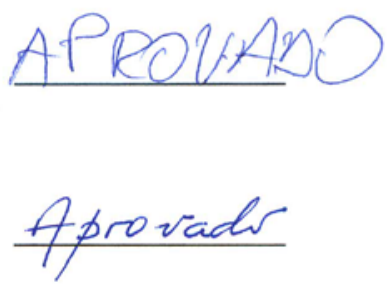

(Universidade Estadual Paulista "Júlio de Mesquita Filho"/UNESP-Ilha Solteira)

Coordenadora do Programa de Pós-Graduação em Engenharia Hidráulica e Saneamento:

Profa. Associada Maria Bernadete A. Varesche Silva

Presidente da Comissão de Pós-Graduação:

Prof. Titular Denis Vinicius Coury 


\section{AGRADECIMENTOS}

Agradeço a minha família por todo o amor incondicional e apoio nos rumos de minha vida.

Ao Prof. Dr. João Luiz Boccia Brandão pela paciência, companheirismo e pelos ensinamentos e direcionamentos proporcionados a pesquisa.

Ao Thiago pela amizade e contribuição com os dados fundamentais para a elaboração do projeto.

Aos bons momentos partilhados com os amigos com que fui agraciado.

A Lôide pelo amor, companheirismo, dedicação e por toda a ajuda nesta jornada de mestrado.

A CAPES pela concessão da bolsa de pesquisa. 


\section{RESUMO}

ABREU, F. G. - análise da influência da distribuição temporal das chuvas intensas e de cenários de uso e ocupação do solo na quantificação dos prejuízos econômicos diretos provocados pelas inundações urbanas. 2013. 162 f. Dissertação (Mestrado em Engenharia Hidráulica e Saneamento) - Escola de Engenharia de São Carlos, Universidade de São Paulo, São Carlos, 2013.

Como já sabemos, as inundações urbanas no Brasil são decorrentes principalmente do processo de urbanização desordenado que se acentuou a partir da década de 50. As inundações causam problemas tais como: perdas humanas, problemas de saúde pública, degradação da qualidade das águas e prejuízos econômicos da ordem de bilhões de reais. Para tanto, a pesquisa objetivou analisar os prejuízos decorrentes de inundações urbanas na bacia do Córrego do Gregório no município de São Carlos - SP, sob duas formas de distribuição temporal de chuvas intensas, considerando seis cenários alternativos de ocupação da bacia e períodos de retorno de 25, 50 e 100 anos. A pesquisa ocorreu em etapas: foram aplicados os métodos de distribuição temporal de chuvas de Huff $1^{\circ}$ quartil e blocos alternados para análise dos hidrogramas de cheia na região central da cidade, próxima ao mercado municipal, área sujeita a inundações frequentes. Na sequência, foram traçadas as manchas de inundação resultantes por meio de Sistema de Informação Geográfica (SIG); cadastrados os imóveis residenciais e comerciais (objetos de estudo) presentes na mancha de inundação; desenvolvido um banco de dados em plataforma SIG com as informações dos imóveis; definidas as profundidades de submersão dos imóveis cadastrados para as condições de contorno do estudo. Finalmente, foram calculados os prejuízos aos imóveis cadastrados decorrentes das profundidades de submersão para os cenários estudados pelos diferentes métodos de distribuição das chuvas. Conclui-se que a alteração do método de distribuição temporal das chuvas pode trazer incertezas quanto à transformação da chuva em vazão e, dessa forma, introduzir diferenças significativas nos resultados. Porém, percebeu-se que essas diferenças possuem correlação direta com o processo de infiltração da água no solo, que por sua vez influi no volume da precipitação efetiva, a qual gerará o escoamento superficial. A variação dos resultados em relação aos métodos de distribuição temporal da chuva para os prejuízos econômicos diretos alcançaram valores da ordem de R\$750.000,00 pelo método de Huff $1^{\circ}$ quartil e da ordem de $\mathrm{R} \$ 5.200 .000,00$ pelo método dos blocos alternados com pico na metade da duração da chuva para o mesmo tempo de retorno e cenário de uso e ocupação do solo.Dessa forma, além da forte influência dos métodos de distribuição temporal das chuvas, os resultados obtidos demonstraram que os prejuízos diretos das inundações urbanas são também afetados pelos cenários de ocupação vislumbrados para a bacia hidrográfica e pelos valores do período de retorno adotado para a tormenta de projeto. Levando em consideração esses três fatores observou-se que, para certas situações, houve uma grande sensibilidade frente aos eventos simulados a qual foi constatada em uma análise das variáveis estatísticas aplicadas ao estudo.

Palavras-chave: inundações urbanas, distribuição temporal de chuvas, prejuízos econômicos. 


\begin{abstract}
ABREU, F. G. - Economic analysis of urban stormwater under two methods of temporal distribution of rainfall. 2013. 162p. Dissertation (Master in Hydraulics and Sanitary Engineering) - School of Engineering of São Carlos, University of São Paulo, São Carlos, 2013.
\end{abstract}

Urban flooding in Brazil is mainly caused by urban development that has increased since 60's decade. Floods cause problems such as: human loss, public health problems, degradation of water quality and economic loss of billions of reais. Therefore, this research aimed to examine the damage caused by flooding in the Gregory watershed located in São Carlos - SP, by two methods of temporal distribution of intense rainfall. The area of study is located in an area subject to flooding, in the central region of the city, next to the municipal market. It was considered six alternative scenarios of land use and return period of 25, 50 and 100 years. First it were applied the methods of temporal distribution of rainfall from Huff 1st quartile and alternating blocks for analysis of runoff hydrographs. In the sequence, it was traced the resulting flooding spots by the Geographic Information System (GIS); it was registered the residential and commercial properties (objects of study) in the flooding spot; it was generated a database on GIS platform with the properties information; it was defined the submersion depths of the registered properties for the studied boundary conditions. Finally the damage was calculated for the registered properties arising from the submersion depths and the scenarios studied by different methods of distribution of rainfall. It was concluded that the change in the method of temporal distribution of rainfall may introduce uncertainties on the transformation of rainfall to flow and, thus, introduce significant differences in the results. However, it was noticed that these differences are directly correlated to the soil infiltration process. That process influences the net storm rainfall volume, which generates the runoff. The direct economic damage reached values of $\mathrm{R} \$ 750,000.00$ using the temporal distribution of rainfall from the Huff 1 st quartile method. On the other hand, the alternating blocks method estimated the damages of $\mathrm{R} \$ 5,200,000.00$, with a peak in the mid of the rain duration for the same return period adopted to the rainfall project. Considering these three factors, it was observed that for certain situations there was a great sensitivity of the simulated events which were identified in a statistical analysis of the variables applied to the study.

Keywords: urban storm water, temporal distribution of rainfall, economic damages. 


\section{LISTA DE FIGURAS}

Figura 1 - Leitos de inundação de um rio 26

Figura 2 - Fluxograma simplificado do plano diretor de drenagem de águas pluviais 30

Figura 3 - Distribuição de Huff nos quatro quartis e probabilidades de ocorrência 47

Figura 4 - Distribuição relativa das precipitações em relação ao tempo aos quatro quartis de distribuição pelo método de Huff com 50\% de probabilidade de ocorrência em cada quartil 47 Figura 5 - Comparação entre a chuva observada na região metropolitana de São Paulo em 1983 e a distribuição de Huff $1^{\circ}$ quartil. 49

Figura 6 - Distribuição temporais da chuva pelo método de Huff. 49

Figura 7 - Comparação entre distribuições temporais de chuva para amortecimento de bacias de detenção. 50 Figura 8 - Hidrogramas característicos para TR=25anos; $\mathrm{CN}=86$; $\mathrm{P}=75,8 \mathrm{~mm}$; e d= 2 horas. 51 Figura 9 - Resultados obtidos por Brandão et. al (2001) para os postos de Portugal e comparação dos resultados com os obtidos por Huff (1967) com 10\% de probabilidade de excedência 53

Figura 10 - Resultados dos eventos de precipitação com pico no $1^{0}$ quartil para chuvas localizadas no Córrego do Gregório - São Carlos/SP . 54

Figura 11 - Resultados dos eventos de precipitação com pico no $2^{0}$ quartil para chuvas localizadas no Córrego do Gregório - São Carlos/SP 54

Figura 12 - Resultados dos eventos de precipitação com pico no $3^{\circ}$ quartil para chuvas localizadas no Córrego do Gregório - São Carlos/SP 54

Figura 13 - Resultados dos eventos de precipitação com pico no $4^{0}$ quartil para chuvas localizadas no Córrego do Gregório - São Carlos/SP ... .55

Figura 14 - Mapa georreferenciado com a delimitação da bacia do Córrego do Gregório....... 65 Figura 15 - Localização da região urbanizada de São Carlos incidente de inundações analisadas neste estudo. 66

Figura 16 - Configuração das sub-bacias presentes na bacia do Córrego do Gregório 67

Figura 17 - Uso do solo na bacia do Córrego do Gregório 68

Figura 18 - Curvas intensidade-duração-frequência para o município de São Carlos/SP ....... 70 Figura 19 - Distribuição temporal da chuva pelo método dos blocos alternados e Huff $1^{\circ}$ quartil .

Figura 20 - Comparação entre o percentual acumulado de chuva em relação ao tempo entre a chuva de projeto de São Carlos/SP e a distribuição de Huff 73 
Figura 21 - Variáveis do método SCS .....

Figura 22 - Uso e ocupação do solo nas macrozonas descritas no plano diretor

Figura 23 - Mapa de logradouros do município de São Carlos - SP

Figura 24 - Mancha de inundação com tempo de retorno de 100 anos no cenário 6 - sem plano diretor. 80

Figura 25 - Delimitação das áreas por setores censitários objeto do estudo 83

Figura 26 - Mapa com os imóveis residenciais e comerciais cadastrados .87

Figura 27 - Índice de ameaça da inundação ao conteúdo dos domicílios - IA $\mathrm{M}_{\mathrm{M} 2}$. 87

Figura 28 - Danos por profundidade de submersão das empresas contidas na mancha de inundação no cenário 6 (sem plano diretor) e TR=100 anos

Figura 29 - Exemplo de gráfico boxplot

Figura 30 - Exemplo de gráfico boxplot construído sem a exclusão dos outliers 91

Figura 31 - Gráfico boxplot com todos os elementos (empresas) presentes 92

Figura 32 - Gráfico boxplot com detalhes das empresas acima do valor máximo na $1^{\text {a }}$ análise 92

Figura 33 - Gráfico boxplot com detalhes das empresas acima do valor máximo na 2aa análise 93

Figura 34 - Gráfico boxplot após a exclusão dos outliers

Figura 35 - Exemplo hidrograma de cheia obtido pelo software Hec-HMS para a sub-bacia 12 no cenário atual com tempo de retorno de 100 anos sob método de distribuição temporal blocos alternados 95

Figura 36 - Exemplo hidrograma de cheia obtido pelo software Hec-HMS para a sub-bacia 12 no cenário atual com tempo de retorno de 100 anos sob método de distribuição temporal Huff $1^{\circ}$ Quartil 96

Figura 37 - Comparação entre as vazões pelos métodos de distribuição de Huff $1^{\circ}$ quartil e blocos alternados no cenário 1 (atual) 97

Figura 38 - Comparação entre as vazões pelos métodos de distribuição de Huff $1^{\circ}$ quartil e blocos alternados no cenário 5 (plano diretor, medidas estruturais e não estruturais) 97

Figura 39 - Comparação entre as vazões pelos métodos de distribuição de Huff $1^{\circ}$ quartil e blocos alternados no cenário 3 (Plano diretor e medidas estruturais) 98

Figura 40 - Comparação entre as vazões pelos métodos de distribuição de Huff $1^{\circ}$ quartil e blocos alternados no cenário 4 (Plano diretor e medidas não estruturais)...... .98

Figura 41 - Comparação entre as vazões pelos métodos de distribuição de Huff $1^{\circ}$ quartil e blocos alternados no cenário 2 (Plano diretor) 
Figura 42 - Comparação entre as vazões pelos métodos de distribuição de Huff $1^{\circ}$ quartil e blocos alternados no cenário 6 (Sem plano diretor). 99 Figura 43 - Comparação entre a vazão máxima obtida pelos métodos de Huff $1^{\circ}$ quartil e blocos alternados. 100

Figura 44 - Comparação entre a área de abrangência da mancha de inundação pelos métodos de distribuição temporal blocos alternados e Huff $1^{\circ}$ quartil. 102 Figura 45 - Mancha de inundação para o tempo de retorno de 25 anos no cenário atual pelo método de distribuição temporal das chuvas Huff $1^{\circ}$ quartil 104 Figura 46 - Mancha de inundação para o tempo de retorno de 25 anos no cenário atual pelo método de distribuição temporal das chuvas blocos alternados 104 Figura 47 - Mancha de inundação para o tempo de retorno de 50 anos no cenário atual pelo método de distribuição temporal das chuvas Huff $1^{\circ}$ quartil ..... 105 Figura 48 - Mancha de inundação para o tempo de retorno de 50 anos no cenário atual pelo método de distribuição temporal das chuvas blocos alternados 105 Figura 49 - Mancha de inundação para o tempo de retorno de 100 anos no cenário atual pelo método de distribuição temporal das chuvas Huff $1^{\circ}$ quartil. 106 Figura 50 - Mancha de inundação para o tempo de retorno de 100 anos no cenário atual pelo método de distribuição temporal das chuvas blocos alternados 106 Figura 51 - Valor do prejuízo ao conteúdo dos imóveis comerciais pelo método dos blocos alternados e tempo de retorno de 25 anos 108 Figura 52 - Valor do prejuízo ao conteúdo dos imóveis comerciais pelo método dos blocos alternados e tempo de retorno de 50 anos 108 Figura 53 - Valor do prejuízo ao conteúdo dos imóveis comerciais pelo método dos blocos alternados e tempo de retorno de 100 anos 109 Figura 54 - Prejuízo acumulado dos imóveis comerciais pelo método de distribuição temporal blocos alternados. 109 Figura 55 - Valor do prejuízo ao conteúdo dos imóveis residenciais pelo método dos blocos alternados e tempo de retorno de 25 anos 110 Figura 56 - Valor do prejuízo ao conteúdo dos imóveis residenciais pelo método dos blocos alternados e tempo de retorno de 50 anos ....

Figura 57 - Valor do prejuízo ao conteúdo dos imóveis residenciais pelo método dos blocos alternados e tempo de retorno de 100 anos.... 111

Figura 58 - Prejuízo acumulado das residências - método blocos alternados. 112 
Figura 59 - Valor do prejuízo ao conteúdo dos imóveis comerciais sob o método de Huff $1^{\circ}$ quartil para o tempo de retorno de 25 anos

Figura 60 - Valor do prejuízo ao conteúdo dos imóveis comerciais sob o método de Huff $1^{\circ}$ quartil para o tempo de retorno de 50 anos

Figura 61 - Valor do prejuízo ao conteúdo dos imóveis comerciais sob o método de Huff $1^{\circ}$ quartil para o tempo de retorno de 100 anos

Figura 62 - Prejuízo acumulado das empresas contidas na mancha de inundação utilizando o método de Huff $1^{\circ}$ quartil

Figura 63 - Valor do prejuízo ao conteúdo dos imóveis residenciais sob o método de Huff $1^{\circ}$ quartil para o tempo de retorno de 25 anos

Figura 64 - Valor do prejuízo ao conteúdo dos imóveis residenciais sob o método de Huff $1^{\circ}$ quartil para o tempo de retorno de 50 anos

Figura 65 - Valor do prejuízo ao conteúdo dos imóveis residenciais sob o método de Huff $1^{\circ}$ quartil para o tempo de retorno de 100 anos

Figura 66 - Profundidade de submersão e Índice de ameaça da inundação ao conteúdo $\left(\mathrm{IA}_{\mathrm{M} 2}\right)$ para um evento hidrológico com tempo de retorno de 25 anos pelo método blocos alternados.

Figura 67 - Profundidade de submersão e Índice de ameaça da inundação ao conteúdo $\left(\mathrm{IA}_{\mathrm{M} 2}\right)$ para um evento hidrológico com tempo de retorno de 50 anos pelo método blocos alternados.

Figura 68 - Profundidade de submersão e Índice de ameaça da inundação ao conteúdo ( $\left.\mathrm{IA}_{\mathrm{M} 2}\right)$ para um evento hidrológico com tempo de retorno de 100 anos pelo método blocos alternados.

Figura 69 - Profundidade de submersão e Índice de ameaça da inundação ao conteúdo $\left(\mathrm{IA}_{\mathrm{M} 2}\right)$ para um evento hidrológico com tempo de retorno de 25 anos pelo método de Huff $1^{0}$ quartil

Figura 70 - Profundidade de submersão e Índice de ameaça da inundação ao conteúdo ( $\mathrm{IA}_{\mathrm{M} 2}$ ) para um evento hidrológico com tempo de retorno de 50 anos pelo método de Huff $1^{\mathrm{o}}$ quartil.

Figura 71 - Profundidade de submersão e Índice de ameaça da inundação ao conteúdo ( $\mathrm{IA}_{\mathrm{M} 2}$ ) para um evento hidrológico com tempo de retorno de 100 anos pelo método de Huff $1^{\mathrm{O}}$ quartil 
Figura 72 - Comparação entre o índice $\mathrm{IA}_{\mathrm{M} 2}$ e o prejuízo acumulado entre o cenário atual e o cenário Plano Diretor com medidas estruturais e não estruturais pelo método de Huff $1^{\circ}$ quartil

Figura 73 - Comparação entre as variáveis estatísticas pelo método blocos alternados e Huff $1^{0}$ quartil.

Figura 75 - Danos por profundidade de submersão por categoria de atividade comercial para a distribuição temporal blocos alternados TR 100 anos cenário sem plano diretor 125 Figura 76 - Curva de Danos por Profundidade de Submersão (DPS) pelo método dos blocos alternados 126

Figura 77 - Curva de danos por profundidade de submersão (DPS) pelo método de Huff $1^{\circ}$ quartil

Figura 78 - Comparação entre as curvas DPS para Huff $1^{0}$ quartil e blocos alternados para o tempo de retorno de 25 anos 128

Figura 79 - Comparação entre as curvas DPS para Huff $1^{\circ}$ quartil e blocos alternados para o tempo de retorno de 50 anos

Figura 80 - Comparação entre as curvas DPS para Huff $1^{0}$ quartil e blocos alternados para o tempo de retorno de 100 anos 130

Figura 81 - Curva de prejuízo acumulado das empresas presentes na mancha de inundação por profundidade de submersão pelo método dos blocos alternados 131

Figura 82 - Curva de prejuízo acumulado das empresas presentes na mancha de inundação por profundidade de submersão pelo método de Huff $1^{\circ}$ quartil.

Figura 83 - Comparação entre as curvas de prejuízo acumulado por altura de submersão para o tempo de retorno de 25 anos

Figura 84 - Comparação entre as curvas de prejuízo acumulado por altura de submersão para o tempo de retorno de 50 anos 134

Figura 85 - Comparação entre as curvas de prejuízo acumulado por altura de submersão para o tempo de retorno de 100 anos 134 Figura 86 - Número de empresas contidas na mancha de inundação utilizando o método de distribuição temporal das chuvas pelos métodos de Huff $1^{\circ}$ quartil e blocos alternados ..... 135 Figura 87 - Comparação entre os prejuízos das empresas pelo método de distribuição temporal blocos alternados e Huff $1^{\circ}$ quartil..... 136 Figura 88 - Comparação entre os prejuízos acumulados das empresas pelos métodos de distribuição temporal das chuvas blocos alternados e Huff $1^{\circ}$ quartil 137 


\section{LISTA DE TABELAS}

Tabela 1 - Crescimento populacional em áreas urbanas e rurais 25

Tabela 2 - Percentual de chuva acumulada no tempo para a distribuição de Huff $1^{\circ}$. Quartil com 50 \% de probabilidade de ocorrência.

Tabela 3 - Relação duração da chuva - quartil - frequência ....................................................50

Tabela 4 - Volume de chuva precipitado por tempo de retorno de acordo com a curva IDF ..72

Tabela 5 - Chuva de projeto adimensional de São Carlos - SP .............................................. 72

Tabela 6 - Valores de CN médio para cada sub-bacia nos respectivos cenários ......................78

Tabela 7 - Caracterização dos moradores presentes nos setores censitários ............................83

Tabela 8 - Caracterização dos domicílios contidos na mancha de inundação..........................83

Tabela 9 - Dados desagregados de rendimento mensal domiciliar ........................................84

Tabela 10 - Classificação das residências brasileiras quanto à classe econômica.....................84

Tabela 11 - Relação da quantidade de bens de uma residência de acordo com sua classe social 85

Tabela 12 - Índice de ameaça da inundação ao conteúdo 88

Tabela 13 - Comparação entre as vazões máximas $\left(\mathrm{m}^{3} / \mathrm{s}\right)$ dos hidrogramas calculados para a área de estudo 100

Tabela 14 - Área das manchas de inundação de acordo com o tempo de retorno, cenário e método de distribuição temporal da precipitação 


\section{LISTA DE QUADROS}

Quadro 1 - Localização dos córregos do município de São Carlos nas macrozonas................ 37

Quadro 2 - Frequência de precipitações ocorridas em três postos de Portugal e os respectivos

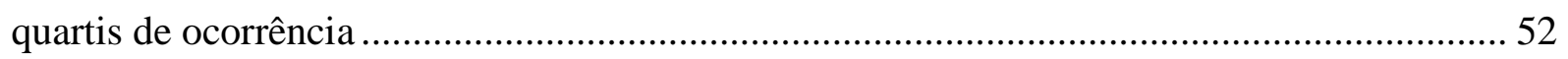

Quadro 3 - Classificação do tipo de atividade e equação utilizada para calcular os danos por profunidade de submersão das empresas contidas na mancha de inundação 81

Quadro 4 - Descrição dos setores censitários contidos na mancha de inundação da área central de São Carlos 
ACISC - Associação Comercial e Industrial de São Carlos

AEI - Áreas de Especiais Interesses

AIDC - Área Impermeável Diretamente Conectada

AINC -Área Impermeável Não Conectada

APA - Área de Proteção Ambiental

AP - Área Permeável

APP - Área de Preservação Permanente

BMP - Best Management Practices

CA - Coeficiente de Aproveitamento

CAB- Coeficiente de Aproveitamento Básico

CAM- Coeficiente de Aproveitamento Máximo (),

CDCC - Centro de Divulgação Científica e Cultural

CEAT - Centro Empresarial de Alta Tecnologia

$\mathrm{CN}$ - Curve Number

CO - Coeficientes de Ocupação

CP - Coeficiente de Permeabilidade

DPS - Danos por profundidade de Submersão

EESC - Escola de Engenharia de São Carlos

EUA - Estados Unidos da América

GEA- Grupo Especial de Análise

GIS - Geographic Information System

GTO - Grupo de Trabalho Técnico e Operacional

HEC - Hydrologic Engineering Center

HMS - Hydrologic Modeling System

$\mathrm{IA}_{\mathrm{M} 2}$-Índice de ameaça da inundação ao conteúdo dos domicílios

IBGE - Instituto Brasileiro de Geografia e Estatística

IDF - Intensidade-Duração-Frequência

IPTU - Imposto Predial e Territorial Urbano

LID - Low Impact Development

MDT - Modelo Digital do Terreno

NIBH - Núcleo Integrado de Bacias Hidrográficas

ONG - Organização Não Governamental 
PD - Plano Diretor

PMSC - Prefeitura Municipal de São Carlos

RAS - River Analysis System

$\mathrm{S}$ - retenção potencial do solo

SCS - Soil Conservation Service

SIG - Sistema de Informação Geográfica

SIGA SC - Sistemas de Informações Geográficas de São Carlos

SMHDU - Secretaria Municipal de Habitação e Desenvolvimento Urbano

TR - Tempo de Retorno

UFSCar - Universidade Federal de São Carlos

USACE - United States Army Corps of Engineers

USDA - United States Department of Agriculture

USP - Universidade de São Paulo

VE - Valor de existência

VEAA - Valoração Econômica de Ativos Ambientais

VET - Valor Econômico Total

VO - Valor de Opção

VNU -Valor de Não-Uso

VU - Valor de Uso 


\section{SUMÁRIO}

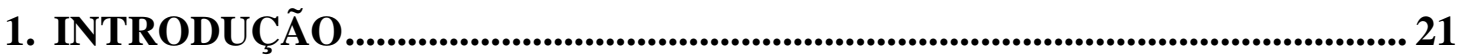

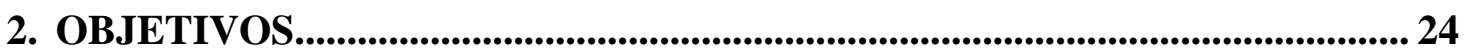

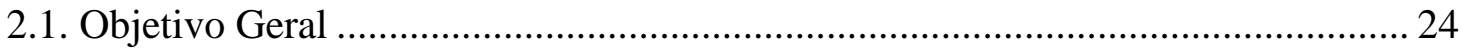

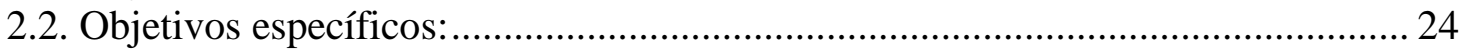

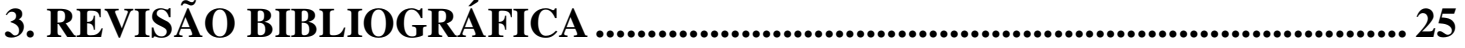

3.1. Processo de urbanização no Brasil ...................................................................... 25

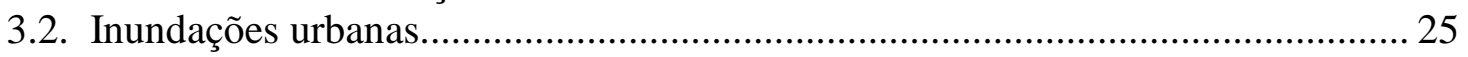

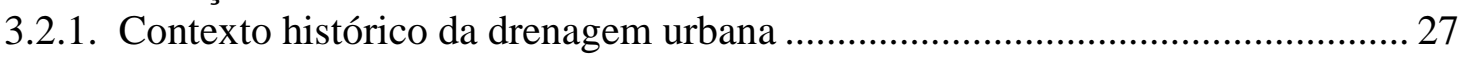

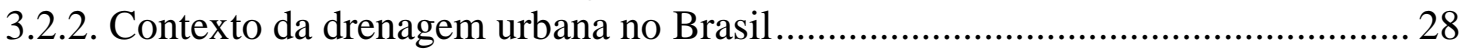

3.2.3. Conceitos relativos á gestão de drenagem urbana sustentável de águas pluviais29

3.3. Plano Diretor de Desenvolvimento Urbano ....................................................... 31

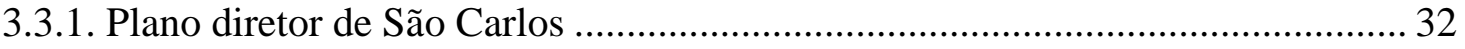

3.4. Plano Diretor de drenagem ambientalmente sustentável do município de São

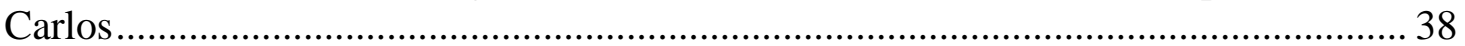

3.5. Conceitos Relativos ao Controle de Enchentes ..................................................... 39

3.5.1. Medidas estruturais de drenagem urbana...................................................... 41

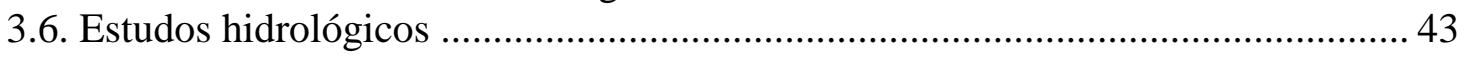

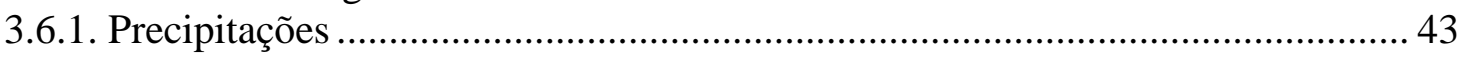

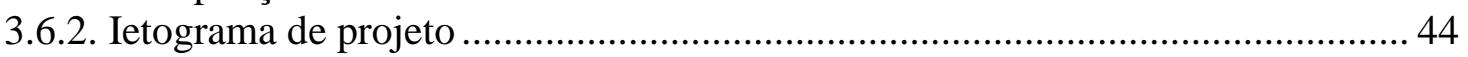

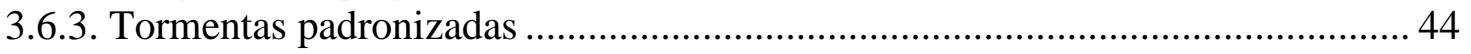

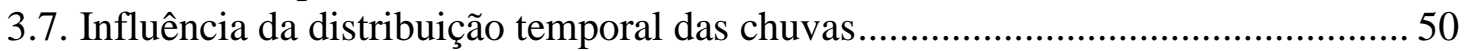

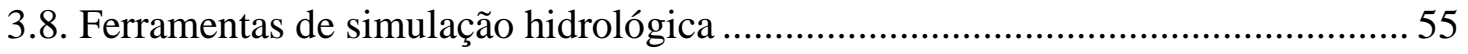

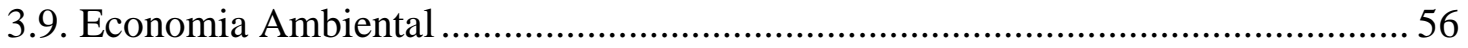

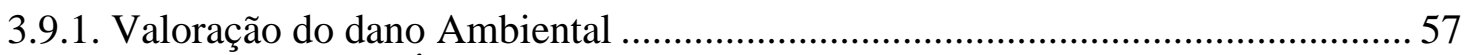

4.0.MATERIAIS E MÉTODOS ............................................................................ 64

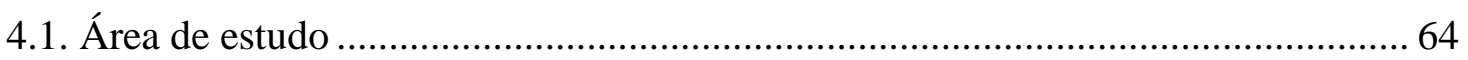

4.2.3. Delimitação das sub-bacias para obtenção dos CN médios.................................. 66

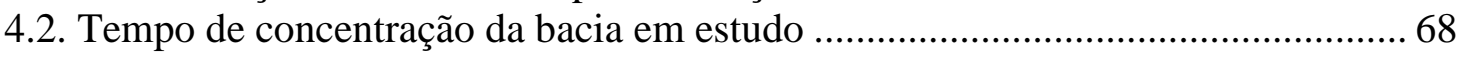

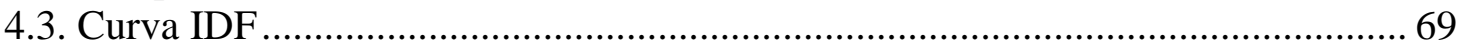

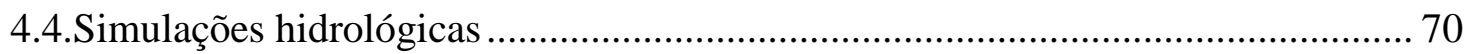

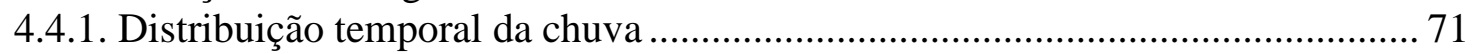

4.3. Medidas compensatórias consideradas na simulação hidrológica .......................... 74

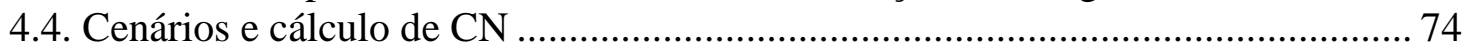

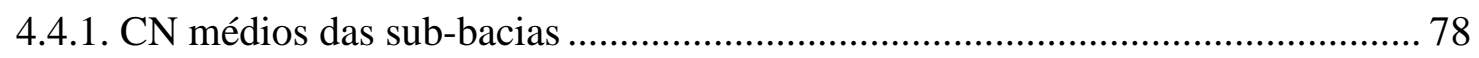

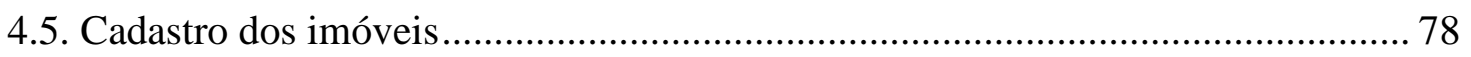

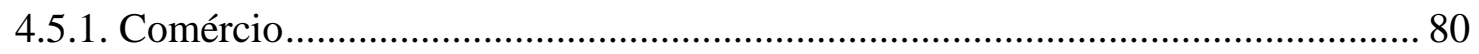

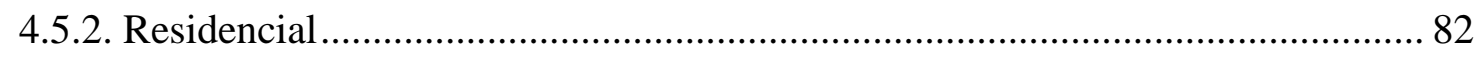

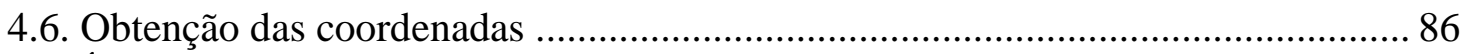

4.7. Índice de ameaça da inundação ao conteúdo dos domicílios ................................. 87

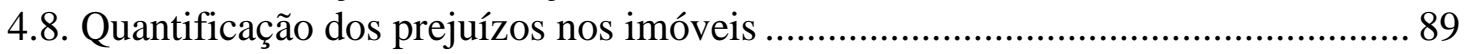

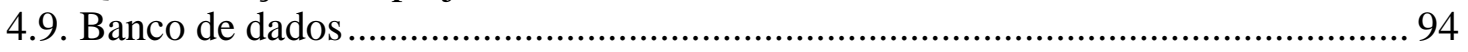

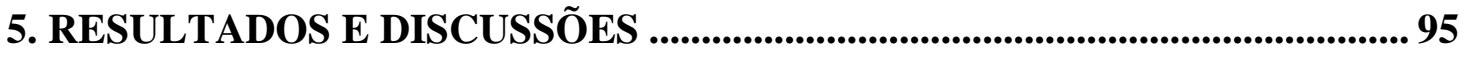

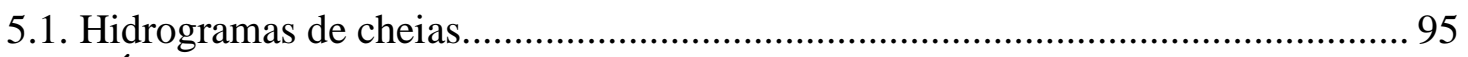

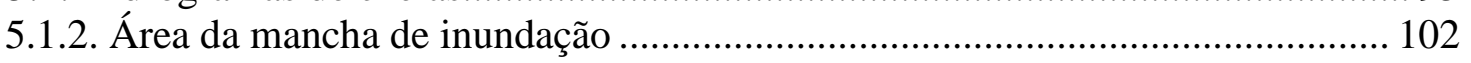

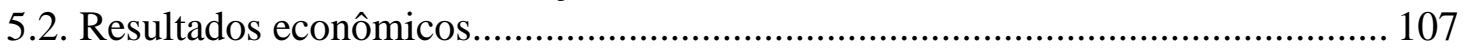

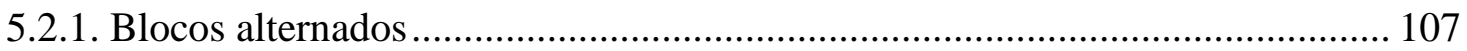

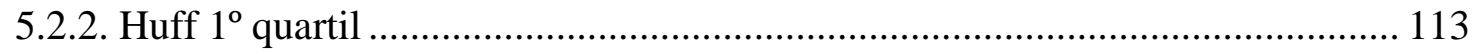


5.3. Análise da profundidade de submersão e relação com o Índice de ameaça da inundação ao conteúdo $\left(\mathrm{IA}_{\mathrm{M} 2}\right)$

5.4. Curvas de danos por profundidade de submersão (DPS)...................................124

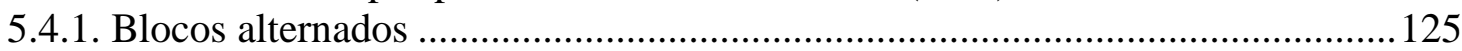

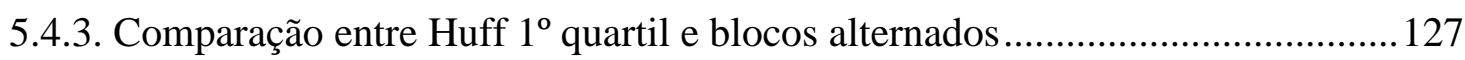

5.5. Curva de prejuízo acumulado por altura de submersão .......................................130

6. CONCLUSÕES E RECOMENDAÇÕES.......................................................139

6.1. Aplicação dos métodos de distribuição temporal para analise dos hidrogramas de cheia 139

6.2. Obtenção das manchas de inundação pelos métodos de distribuição temporais de chuvas aplicados por meio de SIG

139

6.3. Cadastramento dos imóveis residenciais e comerciais presentes na mancha de inundação e banco de dados em plataforma SIG

6.4. Obtenção das profundidades de submersão dos imóveis cadastrados sob as duas formas de distribuição temporal das chuvas em diferentes cenários e tempo de retorno ........140

6.5. Quantificação dos prejuízos nos imóveis decorrentes das profundidades de submersão para diferentes cenários e métodos de distribuição de chuvas

6.6. Analisar as diferenças nos resultados obtidos em função dos três fatores influentes: distribuição temporal das tormentas de projetos, cenários de ocupação e períodos de retorno

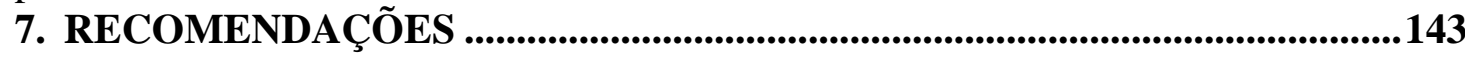

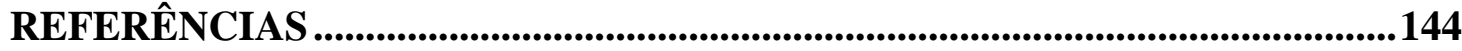

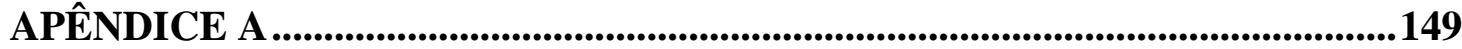

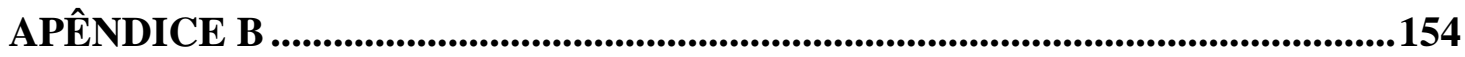

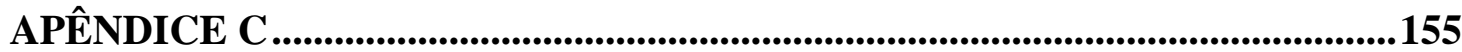

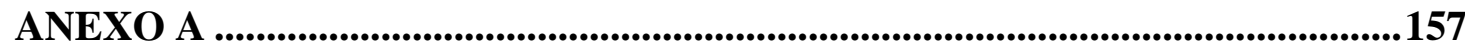

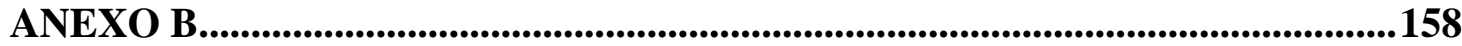

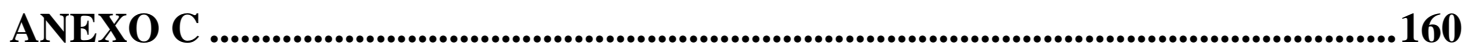

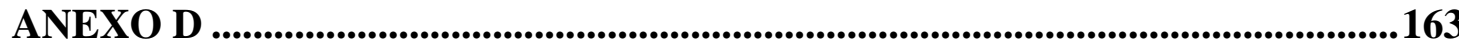




\section{INTRODUÇÃO}

As inundações urbanas no Brasil são decorrentes principalmente do processo de urbanização que se acentuou a partir da década de 50 . As inundações causam problemas como perdas humanas, problemas de saúde pública, degradação da qualidade de vida, poluição das águas e prejuízos econômicos, entre outros.

As perdas econômicas geram prejuízos da ordem de bilhões de reais acarretando em gastos por parte do poder público e da população. Segundo Baptista e Nascimento (1996) e Tucci et al.(2003) os gastos com inundações urbanas no Brasil foram estimados entre US\$ 1 bilhão e US\$ 2 bilhões por ano.

Uma pesquisa da Faculdade de Economia e Administração (FEA) da Universidade de São Paulo (USP) constatou prejuízos anuais decorrentes de alagamentos de R\$ 336 milhões ao ano na cidade de São Paulo, destacando que a cidade já possui 749 pontos de alagamentos e que cada ponto formado após uma chuva forte provoca um prejuízo diário de mais de R\$ 1 milhão ao país. Há projeções realizadas com base no ano de 2008 de prejuízos da ordem de R\$ 762 milhões em escala nacional decorrentes dessas inundações (ARANTES, 2013).

Na cidade de São Carlos - SP, ao analisar as notícias históricas de jornais com base nos anos de 1940 a 2004, foram encontrados 82 eventos de inundações ou alagamentos. Somente na Bacia do Córrego do Gregório, onde se localiza o centro da cidade, foram constatados 64 casos de inundações e 38 intervenções e obras relacionadas à drenagem da malha urbana; porém, o problema ainda persiste nesta região (MENDES e MENDIONDO, 2006). Também nesta bacia foram encontrados valores de prejuízos potenciais decorrentes de cheias severas da ordem de R\$ 20.000.000,00 em um cenário atual com tempo de retorno de 100 anos e de R\$28.000.000,00 para cenários futuros de ocupação para o mesmo TR (GRACIOSA, 2010).

O Plano Diretor de Drenagem Urbana Ambientalmente Sustentável do Município de São Carlos foi elaborado em 2011 para fornecer diretrizes e auxiliar a prefeitura municipal a gerenciar a drenagem urbana do município, de modo a subsidiar a tomada de decisão quanto à redução dos impactos causados pelas inundações.

Na elaboração do plano foram estudadas as condições atuais da drenagem urbana e proposta a adoção de medidas controle de inundação: estruturais e não estruturais. Como medidas estruturais, foram previstos 21 reservatórios de detenção in-line ao longo de diversas bacias da cidade. Em relação às medidas não estruturais, foi proposta a obtenção de recursos 
financeiros, treinamento dos técnicos envolvidos na gestão da drenagem urbana, educação ambiental, orientação para projetos de engenharia e a elaboração de um manual de drenagem urbana que até o momento não ocorreram.

Partindo da análise de que as inundações urbanas são cada vez mais frequentes e que o sistema gestor é, via de regra, defasado e atrasado, e ainda, devido ao fato que há uma carência de pesquisas que relacionem estudos hidrológicos e prejuízos econômicos, esta pesquisa objetivou analisar os prejuízos econômicos diretos decorrentes das inundações urbanas na bacia do Córrego do Gregório no município de São Carlos - SP, considerando duas formas de distribuição temporal para as tormentas projeto e cenários alternativos de ocupação futura da bacia.

Visto que as distribuições temporais das chuvas influenciam de forma significativa os valores dos prejuízos decorrentes das inundações, buscou-se analisar o método dos blocos alternados e o método de Huff com pico de vazão no primeiro quartil.

Deve-se ressaltar que normalmente, no Brasil e em diversos outros países subdesenvolvidos ou em desenvolvimento, as pequenas e médias bacias urbanas ou rurais não contam com dados hidrometeorológicos em quantidade e qualidade que permitam a avaliação de tormentas de projeto para cada local específico. Dessa forma, é comum a aplicação de equações de chuvas intensas na forma de relações I-D-F (Intensidade-Duração-Frequência) que fornecem o valor da intensidade máxima da precipitação para uma dada cidade ou região ao longo da duração da tormenta selecionada e em função do período de retorno adotado.

A partir desse valor, é necessário definir o ietograma de projeto que irá alimentar um modelo de simulação do tipo chuva-vazão para se obter o hidrograma de projeto desejado. Para tanto, torna-se necessário distribuir o total precipitado ao longo da duração escolhida para cada intervalo de tempo do ietograma.

Como a priori, não se conhece essa distribuição temporal — que pode variar tanto no espaço como no tempo e também em relação ao tipo de precipitação — é comum adotar-se distribuições empíricas que procuram representar as condições mais críticas possíveis da evolução temporal da tormenta e assim definir um hidrograma igualmente crítico.

Além da aplicação dos diferentes métodos de distribuições temporais de chuva para geração dos hidrogramas de cheia através do uso de modelo chuva-vazão, foram realizadas simulações hidráulicas por meio de modelo hidrodinâmico, através de simulações hidráulicas com HEC-RAS sob regime de escoamento permanente, que forneceram resultados para definição de manchas de inundação obtidas a partir de software de Sistema de Informações Geográficas - SIG. 
Para cálculo dos prejuízos econômicos, realizou-se o cadastramento dos imóveis residenciais e comerciais (objeto do estudo) presentes na mancha de inundação e gerou-se um banco de dados em plataforma SIG. Como resultado obteve-se a quantificação dos prejuízos dos imóveis cadastrados decorrentes das profundidades de submersão para diversos cenários de uso e ocupação do solo e diferentes períodos de retorno.

Espera-se que esta pesquisa contribua para o avanço dos estudos acerca de análises das distribuições temporais das chuvas relacionadas a prejuízos econômicos, já que foram encontrados poucos trabalhos que abordaram o tema em questão. Esse aspecto é de fundamental importância para se avaliar com eficácia o desempenho de medidas de controle de inundações, quer sejam estruturais ou não estruturais, que realmente resultem em benefícios para a população afetada. 


\section{OBJETIVOS}

\subsection{Objetivo Geral}

O objetivo geral desta pesquisa consiste em analisar os prejuízos econômicos decorrentes de inundações urbanas na bacia do Córrego do Gregório no município de São Carlos - SP, sob duas formas de distribuição temporal de chuvas, para cenários alternativos de ocupação futura da bacia e diversos períodos de retorno.

\subsection{Objetivos específicos:}

$\checkmark$ Aplicar os métodos de distribuição temporal de chuvas de Huff $1^{0}$ quartil e blocos alternados para geração dos hidrogramas de cheia na região próxima ao mercado municipal situado no centro da cidade de São Carlos - SP, dentro da bacia do Córrego do Gregório;

$\checkmark$ Obter as manchas de inundação pelos métodos de distribuição temporal de chuvas aplicando modelagem hidráulica e Sistema de Informação Geográfica (SIG);

$\checkmark$ Cadastrar os imóveis residenciais e comerciais presentes na mancha de inundação e gerar um banco de dados em plataforma SIG;

$\checkmark$ Obter as profundidades de submersão dos imóveis cadastrados sob as duas formas de distribuição temporal das chuvas em diferentes cenários e tempos de retorno;

$\checkmark$ Quantificar os prejuízos nos imóveis cadastrados decorrentes das profundidades de submersão para os cenários estudados pelos métodos de Huff $1^{\circ}$ quartil e blocos alternados.

$\checkmark$ Analisar as diferenças nos resultados obtidos em função dos três fatores influentes: distribuição temporal das tormentas de projetos, cenários de ocupação e períodos de retorno. 


\section{REVISÃO BIBLIOGRÁFICA}

\subsection{Processo de urbanização no Brasil}

O processo de urbanização no Brasil se deu principalmente devido ao êxodo rural (1950 a 1980) decorrente da metropolização da urbanização brasileira, em que as cidades com mais de 500 mil habitantes passaram de 7,7\% para 16,2\% da população total (SCHMIDT e FARRET, 1986).

No período de 1980 a 1991, a população urbana cresceu de 68\% para mais de 75\%, enquanto as áreas rurais enfrentavam um decréscimo de $0,6 \%$ ao ano, representando um crescimento absoluto de mais 30 milhões de residentes urbanos (MARTINE, 1994).

Entre os anos 1991 a 2000 a população urbana passou a ser de 7,3 para 9,5 vezes maior que a população rural, o que ocasionou a redução da população rural na ordem de quatro milhões de pessoas (IBGE, 2001).

Em 2010, a população brasileira era composta de 190.732.694 habitantes, e destas 84,36\% viviam em áreas urbanas e apenas 15,64\% da população residiam em áreas rurais. O aumento da população no período de 1950 a 2010 é apresentado na Tabela 1.

Tabela 1 - Crescimento populacional em áreas urbanas e rurais

\begin{tabular}{c|c|c|c|c}
\hline Ano & $\begin{array}{c}\text { População Rural } \\
\text { (habitantes) }\end{array}$ & $\begin{array}{c}\text { População Urbana } \\
\text { (habitantes) }\end{array}$ & $\begin{array}{c}\text { Percentual da } \\
\text { população urbana }\end{array}$ & $\begin{array}{c}\text { Percentual da } \\
\text { população rural }\end{array}$ \\
\hline $\mathbf{1 9 5 0}$ & 33.161 .506 & 18.782 .891 & 36,16 & 63,84 \\
\hline $\mathbf{1 9 6 0}$ & 38.987 .526 & 32.004 .817 & 45,08 & 54,92 \\
\hline $\mathbf{1 9 7 0}$ & 41.603 .839 & 52.904 .744 & 55,98 & 44,02 \\
\hline $\mathbf{1 9 8 0}$ & 39.137 .198 & 82.013 .375 & 67,70 & 32,30 \\
\hline $\mathbf{1 9 9 1}$ & 36.041 .633 & 110.875 .826 & 75,47 & 24,53 \\
\hline $\mathbf{1 9 9 6}$ & 33.993 .332 & 123.076 .831 & 78,36 & 18,75 \\
\hline $\mathbf{2 0 0 0}$ & 31.845 .211 & 137.953 .959 & 81,25 & 15,64 \\
\hline $\mathbf{2 0 1 0}$ & 29.830 .007 & 160.925 .792 & 84,36 & \\
\hline $\begin{array}{c}\text { População } \\
\text { Total }\end{array}$ & $\mathbf{1 9 0 . 7 5 5 . 7 9 9}$ & & $\mathbf{1 0 0 \%}$ \\
\hline
\end{tabular}

Fonte: Adaptado de IBGE (2011)

\subsection{Inundações urbanas}

De acordo com Tucci (1995), as inundações em áreas urbanas são consequência de dois processos: inundações em áreas ribeirinhas e inundações provocadas pela urbanização. As inundações em áreas ribeirinhas ocorrem principalmente pelo processo natural no qual o rio ocupa o seu leito maior de acordo com eventos chuvosos extremos. 
As várzeas, embora estejam com menor frequência alagadas, fazem parte dos cursos d’água naturais, tanto quanto a sua calha principal. Por esta razão, em geomorfologia a várzea também recebe a denominação de leito maior ou secundário. As características dos leitos de inundação são apresentadas na Figura 1.

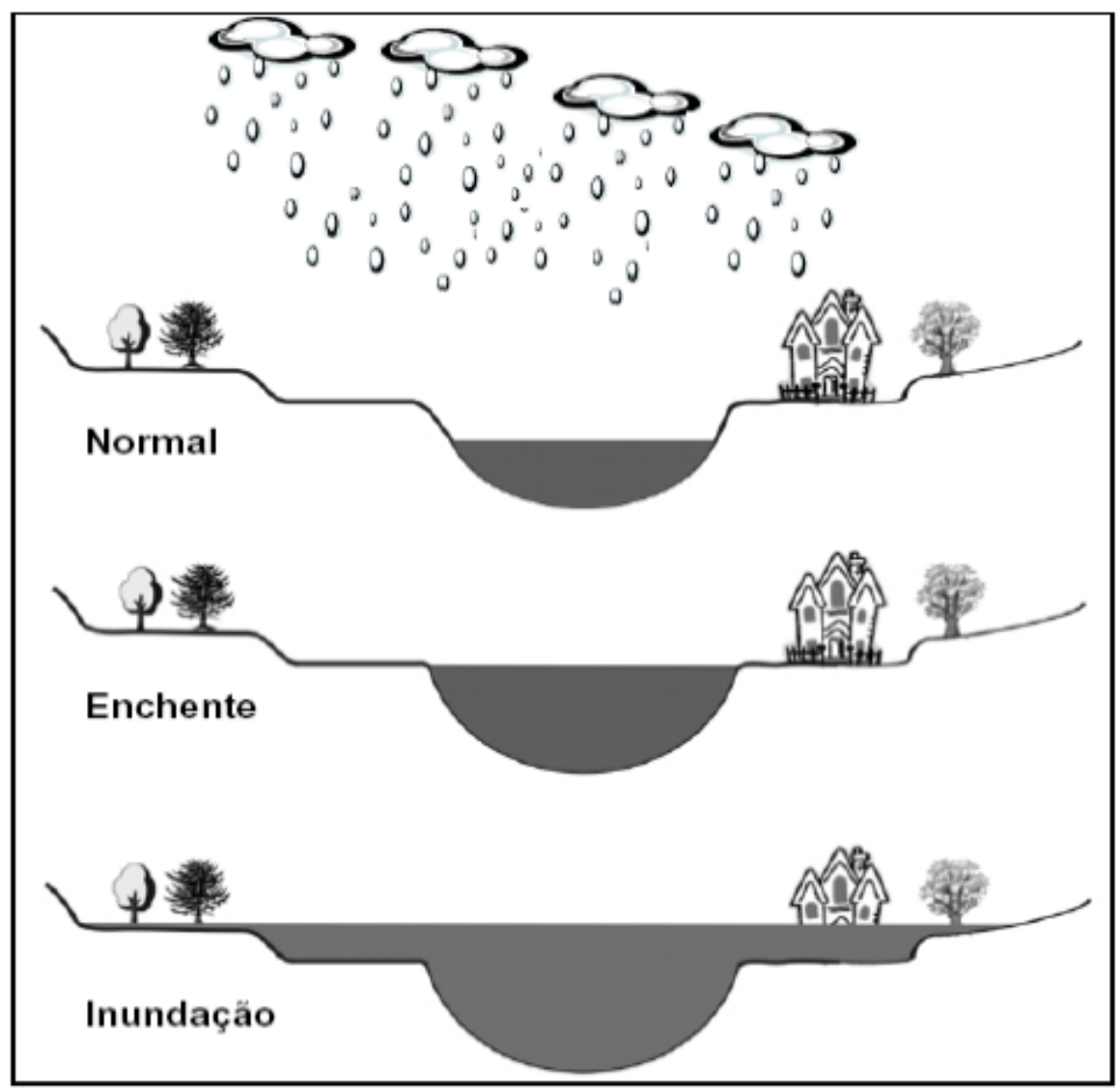

Figura 1 - Leitos de inundação de um rio Fonte: Goerl e Kobyiama (2005)

As funções primárias de um curso d'água e de sua várzea associada são a coleta, armazenamento e veiculação das vazões de cheias. Essas funções não podem ser relegadas a um plano secundário em favor de outros usos, sem a adoção de medidas compensatórias normalmente onerosas. Respeitada essa restrição, as várzeas têm a potencialidade de contribuir para a melhoria da qualidade da água e do ar, a manutenção de espaços abertos, a preservação de ecossistemas importantes e acomodação de redes de sistemas urbanos adequadamente planejados.

A urbanização tem potencial para aumentar tanto o volume quanto as vazões do escoamento superficial direto. A influência da ocupação de novas áreas deve ser analisada no contexto da bacia hidrográfica na qual estão inseridas, de modo a se efetuarem os ajustes necessários para minimizar a criação de futuros problemas de inundações. 
A simples canalização de um trecho de córrego, por exemplo, poderá reduzir os riscos de inundação de uma determinada área por certo tempo. Essa solução, entretanto, causará sérios impactos. A aceleração do escoamento agravará as inundações a jusante, aumentará o transporte de lixo e sedimentos, que se acumularão nos trechos de menor velocidade, e aumentará a erosão no trecho subsequente ao trecho canalizado. A falsa sensação de segurança provocada pela obra atrairá a população e as atividades econômicas para as áreas mais próximas ao córrego, reduzindo o espaço natural das enchentes. Além disso, se juntamente com a obra não houver o controle da impermeabilização da bacia, as vazões aumentarão gradativamente até que a capacidade do canal seja superada.

Para contornar esses impactos, dentro desta mesma visão tradicional, amplia-se mais ainda a capacidade e a extensão do trecho canalizado instalando-se aí um círculo vicioso, que levará à necessidade de investimentos cada vez maiores para solucionar um problema que poderia ter sido evitado na origem.

Os impactos sobre a população são causados pela ocupação inadequada do espaço urbano, condicionada aos seguintes fatores: inexistência nos Planos Diretores Urbanos e restrições ao loteamento de áreas com risco de inundações; invasão pela população de baixa renda de áreas ribeirinhas pertencentes ao poder público; ocupação de áreas de médio risco, que são atingidas com frequência menor; e pela falta de um Plano Municipal de Saneamento Básico.

As inundações provocadas pela urbanização ocorrem pelo aumento da frequência e magnitude das enchentes devido à ocupação do solo com superfícies impermeáveis e às redes de condutos de escoamento. Além disso, obstruções ao escoamento nos condutos e canais, e projetos de drenagem inadequados podem causar alagamentos.

\subsubsection{Contexto histórico da drenagem urbana}

O desenvolvimento da drenagem urbana está estritamente ligado ao crescimento das populações nas áreas urbanas. As obras de evacuação das águas pluviais surgiram na Roma Antiga, esta denominada “cloaca máxima” (termo latim utilizado para designar drenagem urbana), foi umas das primeiras obras de grandes dimensões a propiciar uma melhoria da qualidade de vida das populações. As redes romanas são classificadas como sistemas unitários de drenagem, pois transportam as águas residuais domésticas e as águas pluviais em um mesmo canal (BAPTISTA, NASCIMENTO e BARRAUD, 2005). 
Segundo os autores supracitados, na Idade Média as áreas urbanas eram ocupadas de forma estratificada e as populações mais desfavorecidas ocupavam as áreas baixas propensas às inundações periódicas. Além disso, os sistemas de evacuação das águas pluviais e esgotamento sanitário caíram em desuso pela falta de manutenção, fato que levou ao conceito denominado “tout à La rue” acarretando em condições de vida humana insalubres, já que as águas residuais e pluviais não eram coletadas, sendo simplesmente lançadas na rua.

Essa situação deu origem ao termo "cidade pútrida”, em que a lama misturada com esgoto tomava conta do sistema viário e deixava um odor desagradável perceptível a distância, tendo como consequências epidemias de cólera e tifo, levando a Europa a levantar as questões de insalubridade pública que só foram questionadas durante o Renascimento, quando os cursos de água foram transformados em esgotos com a realização de obras de regularização de canalização dos rios (BAPTISTA, NASCIMENTO e BARRAUD, 2005).

Não muito diferente dos dias de hoje, as populações economicamente menos favorecidas habitam as áreas mais baixas e ficam sujeitas às inundações que carregavam toda a água contaminada lançada nas ruas.

\subsubsection{Contexto da drenagem urbana no Brasil}

No Brasil colonial, as soluções sanitárias (abastecimento público de água e evacuação dos dejetos) ficavam sob encargo dos indivíduos, como por exemplo, a captação de água em mananciais e as ações de saneamento voltadas à drenagem. No século XVII surgem as primeiras obras de drenagem: implantação de diques, canais e ancoradouros, aterramento e drenagem.

Já no século XVIII os serviços de infraestrutura eram feitos por intermédio de concessão à iniciativa privada e, embora tenha se construído algumas redes para abastecimento e esgotamento sanitário, estes serviços abrangiam apenas os núcleos centrais urbanos,que atendiam uma pequena parcela da população. Em 1850, devido ao surgimento da febre amarela, comissões de saúde e engenharia foram criadas para unificar os serviços sanitários do Império e instituir o Conselho Superior de Saúde Pública com funções normativas (SILVA, 2000).

No século XIX, surge na Europa como medida de saúde pública o conceito higienista. Este visa afastar as águas pluviais e residuais dos centros urbanos e eliminação sistemática das águas paradas ou empoçadas nas cidades. No Brasil, as primeiras canalizações de esgoto ocorreram em 1864 no Rio de Janeiro, porém o conceito higienista só foi aplicado 
efetivamente a partir do ano de 1889 com a implantação do sistema separador absoluto, que diferente da Europa, conduzia as águas residuais e pluviais através de tubulações separadas e exclusivas (SANTOS, 1928 apud SILVEIRA, 1998).

O conceito de tecnologias alternativas de drenagem urbana surgiu na Europa e América do Norte em meados da década de 70, juntamente com técnicas de remediação conhecidas como medidas compensatórias de drenagem, ou Best Management Practices (BMPs), enquanto que no Brasil ainda se iniciava a implantação das redes de drenagem nas cidades.

As BMPs contrapõem a abordagem higienista de livrar-se das águas o mais rápido possível, mantendo o conceito de neutralizar os efeitos do processo de urbanização sobre os processos hidrológicos. Essas técnicas buscam tratar o escoamento pluvial no local em que é gerado, através dos processos de armazenamento, detenção e infiltração das águas pluviais.

Assim como as BMPs, surge em meados de 1990 uma nova abordagem de gestão sustentável de drenagem conhecida como Desenvolvimento de Baixo Impacto (Low Impact Development - LID). Esta busca compatibilizar projetos hidrologicamente funcionais e esteticamente agradáveis para controlar as águas pluviais e minimizar seus impactos sobre as superfícies urbanas (PRINCE GEORGE, 1999).

\subsubsection{Conceitos relativos á gestão de drenagem urbana sustentável de águas pluviais}

A gestão sustentável das águas pluviais urbanas tem como fundamento o conceito de desenvolvimento urbano de baixo impacto (LID), que se traduz em soluções mais eficazes e econômicas quando comparadas às soluções tradicionais de drenagem urbana.Este conceito consiste na preservação do ciclo hidrológico natural, a partir da redução do escoamento superficial adicional gerado pelas alterações da superfície do solo decorrentes do desenvolvimento urbano (PRINCE GEORGE, 1999).

A denominação Plano Diretor de Drenagem Sustentável é dada como referência ao plano que estabelece as diretrizes e objetivos relativos à drenagem urbana. Este é uma ferramenta de planejamento que possibilita implantar soluções efetivas de baixo impacto que trazem ao município benefícios tangíveis e duradouros. O plano tem como unidade de planejamento cada bacia hidrográfica do município (MINISTÉRIO DAS CIDADES, 2012).

Para implantação do plano é necessário que este seja articulado com demais políticas de desenvolvimento urbano, tais como: zoneamento, habitação, infraestrutura, entre outros. $\mathrm{O}$ fluxograma do plano diretor de drenagem de águas pluviais é apresentado na Figura 2. 


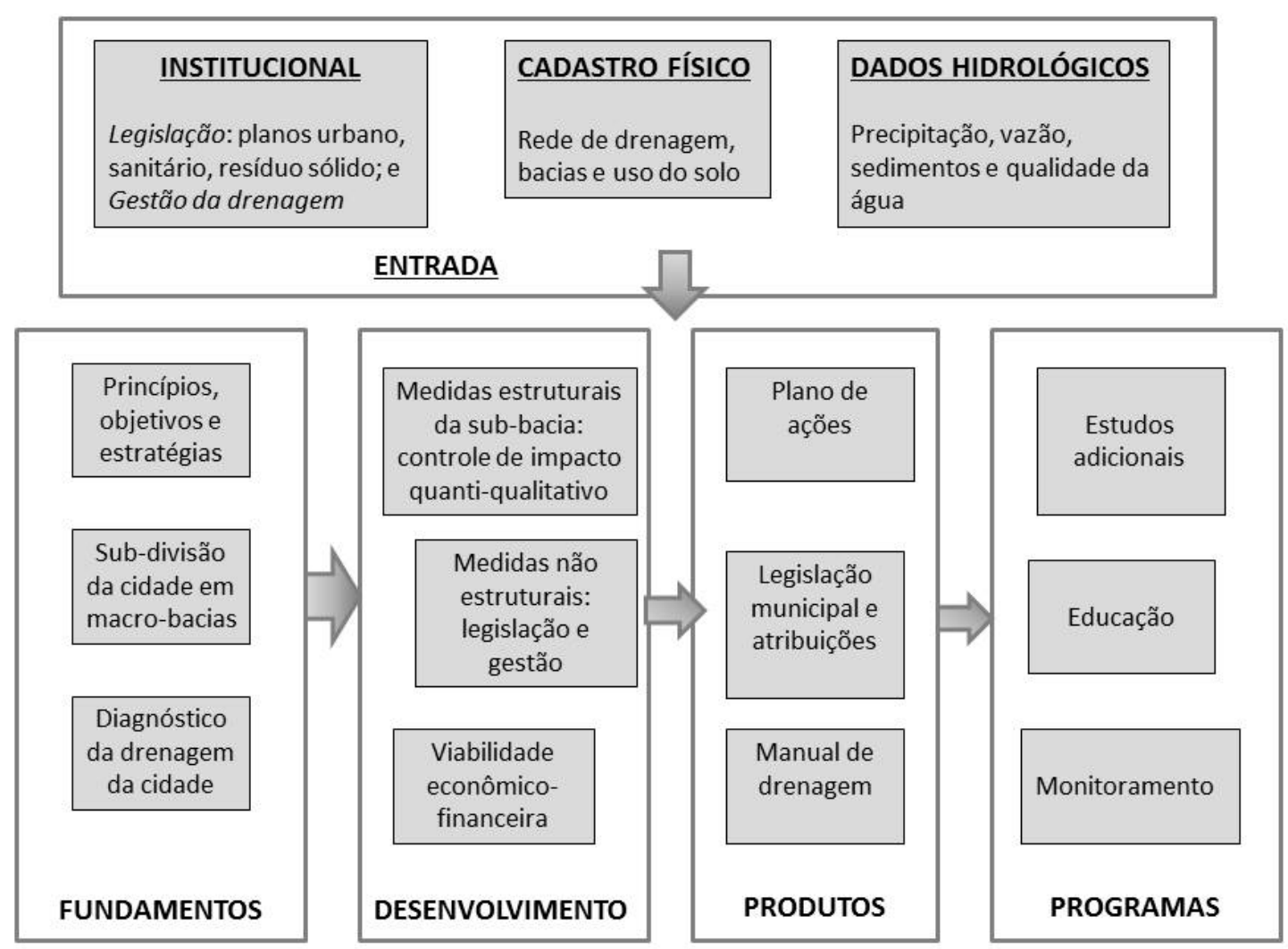

Figura 2 - Fluxograma simplificado do plano diretor de drenagem de águas pluviais Fonte: Adaptado de TUCCI(2002)

Segundo o Ministério das Cidades (2012), os princípios que regem o plano, na visão do desenvolvimento urbano sustentável, são interdisciplinares no diagnóstico e na solução dos problemas de inundação. Dentre os princípios, podem ser destacados:

$\checkmark$ O escoamento pluvial não pode ser ampliado pela ocupação urbana da bacia;

$\checkmark$ Cada empreendimento urbano deve implantar medidas de controle para que a cheia natural não aumente;

$\checkmark$ As medidas de controle propostas para uma bacia não devem transferir impactos para outra bacia;

$\checkmark$ O sistema de águas pluviais deve ser integrado ao sistema de saneamento ambiental;

$\checkmark$ O plano deve propor medidas para o controle do material sólido e a redução da carga poluente das águas pluviais.

Para que os parâmetros de escoamento superficial planejados não sejam superados, o plano de águas pluviais deve regulamentar a ocupação do território por meio do controle das áreas de expansão e da limitação do adensamento das áreas ocupadas. 


\subsection{Plano Diretor de Desenvolvimento Urbano}

O Plano Diretor é uma lei municipal pautado pelo Estatuto da Cidade (Lei Federal 10.257/01), ou seja, é ele que diz como o Estatuto da Cidade será aplicado no município. Já o Estatuto da Cidade diz como deve ser feita a política urbana em todo o país. Este tem o objetivo de garantir o direito à cidade para todos e, para isso, traz algumas regras para se organizar o território do município. É ele que detalha e desenvolve os artigos 182 e 183 do capítulo II referente à política urbana da Constituição Federal.

O artigo 183 da Constituição Federal trata do usucapião das propriedades urbanas, com exceção de propriedades públicas. Já o artigo 182 diz respeito à política de desenvolvimento urbano, executada pelo poder público municipal, que tem por objetivo ordenar o pleno desenvolvimento das funções sociais da cidade e garantir o bem-estar de seus habitantes. Nos incisos deste capítulo destacam-se:

A obrigatoriedade do plano diretor para cidades com mais de vinte mil habitantes, sendo este o instrumento básico da política de desenvolvimento e de expansão urbana;

$\checkmark$ A importância do plano diretor, destacando que a propriedade urbana cumpre sua função social quando atende às exigências fundamentais de ordenação da cidade expressas no plano diretor;

$\checkmark$ Destaca que as desapropriações de imóveis urbanos serão feitas com prévia e justa indenização em dinheiro;

A exigência mediante lei federal que o proprietário do solo urbano não edificado, subutilizado ou não utilizado de promover seu adequado aproveitamento, sob pena de: parcelamento ou edificação compulsórios; imposto sobre a propriedade predial e territorial urbana progressivo no tempo; e desapropriação com pagamento mediante títulos da dívida pública de emissão previamente aprovada pelo Senado Federal, com prazo de resgate de até dez anos, em parcelas anuais, iguais e sucessivas, assegurados o valor real da indenização e os juros legais.

O Estatuto da Cidade regulamenta os artigos citados acerca da política urbana e dispõe sobre o conteúdo mínimo de um Plano Diretor, estabelecendo que o processo de sua formulação seja necessariamente participativo. Também introduz cinco instrumentos para o ordenamento territorial: 1 - o parcelamento, edificação ou utilização compulsória (que podem vir a gerar o IPTU progressivo no tempo); 2 - o direito de preempção; 3 - a outorga onerosa do direito de construir e de alteração de uso do solo; 4 - as operações urbanas consorciadas; 5 - a transferência do direito de construir. 
Segundo Braga (1995) os Planos Diretores são instrumentos políticos que objetivam tornar transparente e democratizar a política urbana e possuem três aspectos básicos: o aspecto político, o aspecto da transparência e o aspecto da democratização.

Sobre o aspecto político Braga (1995) destaca que os planos diretores de desenvolvimento urbano não podem ser um produto eminentemente técnico, sem participação efetiva do agente político, pois assim exclui-se a parcela da população do jogo político e ainda justificam-se, pela suposta neutralidade científica a tomada de decisões que favorecem determinadas parcelas da sociedade. No aspecto da transparência, destaca-se a importância de tornar público as diretrizes e prioridades do crescimento urbano de maneira transparente. Já o aspecto da democratização é o que garante a transparência do processo e garante a participação de entidades representativas da sociedade no processo de planejamento municipal.

\subsubsection{Plano diretor de São Carlos}

\section{Processo de elaboração do Plano Diretor}

O processo de elaboração contou com as Assessorias da ONG Instituto Pólis e da Prof $^{a}$ Sarah Feldman do Programa de Pós Graduação do Curso de Arquitetura e Urbanismo da EESC - USP. Este se deu em cinco etapas, sendo estas:

$\checkmark$ Realização de plenárias públicas para debate e divulgação da evolução dos trabalhos realizados;

$\checkmark$ Constituição de um comitê consultivo, com representantes da sociedade civil organizada que debateram o diagnóstico, identificando problemas e potencialidades em diferentes temáticas, formatando-se grandes eixos propositivos com diretrizes e princípios para o Plano no contexto de São Carlos;

$\checkmark$ Constituição de Comissão Executiva com membros de diferentes setores da Administração Pública Municipal como órgão coordenador das ações do governo em relação ao processo de elaboração;

$\checkmark$ Constituição do GTO - Grupo de Trabalho Técnico e Operacional com técnicos de diferentes setores do governo, sob a coordenação geral da SMHDU - Secretaria Municipal de Habitação e Desenvolvimento Urbano, cuja atribuição foi o desenvolvimento dos trabalhos de pesquisa, entrevistas, mapeamento e levantamentos afetos ao Plano e a cada tema debatido, bem como a organização de todos os eventos realizados; 
$\checkmark$ Reuniões Setoriais para discussão do conteúdo do Plano com diferentes segmentos da sociedade civil para compartilhamento do diagnóstico e das propostas desenvolvidas;

\section{Conteúdo do Plano Diretor de São Carlos}

O Plano Diretor de São Carlos foi instituído em novembro de 2005 pela Lei $\mathrm{n}^{\circ}$ 13.691. A lei é basicamente dividida em seis títulos que abordam: 1 - os princípios, objetivos e diretrizes gerais da política urbana; 2 - o ordenamento territorial do município; 3 - o parcelamento, uso e ocupação do solo; 4 - os instrumentos de política urbana; 5 - o sistema de gestão e planejamento do desenvolvimento urbano; e 6 - as disposições gerais, finais e transitórias.

\section{1 - Princípios, objetivos e diretrizes gerais da política urbana}

Cabe ressaltar neste trabalho que é principio da política urbana a compatibilidade com a preservação do meio ambiente se refere ao controle da poluição do ar, da água,do solo e da destinação dos resíduos, assim como a fluidez de drenagem das águas pluviais e dos corpos d'água, a maior permeabilidade do solo, à maior preservação de sua cobertura vegetal e da vegetação significativa existente.

\section{$\underline{2 \text { - Ordenamento territorial do município }}$}

O zoneamento, como estratégia da política urbana, consistem no estabelecimento de zonas com características semelhantes com o propósito de favorecer a implementação dos instrumentos de ordenamento e controle urbano. O macrozoneamento de São Carlos divide o território do município considerando a infraestrutura instalada, as características de uso e ocupação do território do município, as características do meio ambiente natural e construído, a implementação de ações de planejamento.

Acerca do ordenamento territorial do município constituíram-se as Macrozonas e as Zonas e Áreas de Especial Interesse. As macrozonas dividem-se em Macrozona Urbana e Macrozona de Uso Multifuncional Rural:

Macrozona Urbana: composta por áreas dotadas de infraestrutura, serviços e equipamentos públicos e comunitários. Apresenta maior densidade construtiva e populacional, 
que requerem uma qualificação urbanística, e condições de atrair investimentos imobiliários privados. Subdivide-se, por sua vez em:

$\checkmark$ Zona de Ocupação Induzida - Zona 1: composta por áreas do território que requerem uma qualificação urbanística e que têm as melhores condições de infraestrutura da cidade. Tem como características o uso misto com predominância de comércio e serviços, em detrimento de uso habitacional na área central; concentração de população de alta renda, com predominância de população idosa no centro; concentração de imóveis de interesse histórico e cultural, e de imóveis não edificados, não utilizados e subtilizados. É contida inteiramente na faixa localizada entre as barreiras da mobilidade urbana formadas pela ferrovia da Rede Ferroviária Federal e da Rodovia Washington Luiz - SP 310.

$\checkmark$ Zona de Ocupação Condicionada - Zona 2: é composta por áreas com predominância de uso misto do território com grande diversidade de padrão ocupacional. Tem como características fragmentação e descontinuidade do sistema viário; presença de áreas com carência de infraestrutura de drenagem; ocorrência de bolsões com deficiência de áreas públicas ou de equipamentos públicos; ocorrência de bairros que exigem a transposição das barreiras da mobilidade urbana em razão da ferrovia da Rede Ferroviária Federal e da Rodovia Washington Luiz - SP 310; ocorrência de loteamentos com uso misto consolidado ferindo o disposto nos contratos de loteamentos, mas passíveis de regularização por meio de outorga onerosa de alteração de uso do solo.

$\checkmark$ Zona de Recuperação e Ocupação Controlada - Zona 3 (3A e 3B): são zonas com fragilidades sociais e ambientais.

$\checkmark$ A zona 3A apresenta as seguintes características: encostas com alta declividade; solo suscetível a erosões com córregos assoreados; infraestrutura precária; parcelamentos irregulares, localizados nas proximidades de encostas de alta declividade; parcelamentos irregulares, localizados em áreas isoladas com precariedade de interligação viária com a malha urbana consolidada; concentração da população de baixa renda.

$\checkmark$ A zona 3B apresenta as seguintes características: localização em área de proteção e recuperação do manancial de captação superficial do Córrego do Monjolinho; dificuldade de acesso em função da barreira formada pela Rodovia Washington Luiz - SP 310; loteamentos com precariedade no sistema de drenagem; carência de equipamentos públicos; ocorrência de loteamentos com uso misto consolidado ferindo o disposto nos contratos de loteamentos a serem regularizados por meio de outorga onerosa de alteração de uso do solo, mas passíveis de regularização por meio de outorga onerosa de alteração de uso do solo. 
As áreas correspondentes aos campi universitários (UFSCar - Universidade Federal de São Carlos e USP - Universidade de São Paulo - Campus II) estão inseridas no macrozoneamento do município, porém não se enquadram em nenhuma das zonas já descritas. Na lei os campi são denominados apenas como Campi universitários contíguos à malha urbana.

Macrozona de Uso Multifuncional Rural: é composta por áreas de uso agrícola, extrativista ou pecuário, com áreas significativas de vegetação natural, com condições de permeabilidade próximas aos índices naturais; por áreas de preservação ambiental formadas por reservas florestais, parques e reservas biológicas; e por áreas de uso não agrícolas, como chácaras de recreio, lazer, turismo, fazendas históricas, indústrias e sedes de distritos.

Nesta macrozona há presença de nascentes da bacia do Ribeirão dos Negros e do Quilombo a leste, proximidade de nascentes da bacia do Ribeirão das Araras ao norte e proximidade com as nascentes da bacia do Ribeirão do Chibarro a oeste. E também região do espigão divisor de águas das duas grandes bacias hidrográficas do Município, Tietê - Jacaré e Mogi - Guaçu. Esta macrozona subdivide-se em:

$\checkmark$ Zona de Regulação e Ocupação Controlada - Zona 4 (4A e 4B): apresentam como característica comum o fato de estarem localizadas em áreas com fortes tendências para a expansão urbana, apresentando usos diversificados, configurando-se como transição entre o meio rural e o meio urbano. Na zona 4B encontram-se nascentes do Córrego do Santa Maria do Leme e proximidade dos Córregos do Monjolinho, do Água Quente e do Água Fria.

$\checkmark$ Zona de Proteção e Ocupação Restrita - Zona 5 (5A e 5B): são áreas de proteção e recuperação dos mananciais, de nascentes do Córrego do Gregório e parte da Área de Proteção Ambiental (APA) do Corumbataí. A zona 5B abrange parte da área de preservação do manancial de abastecimento público, formado pela bacia de captação do Córrego do Feijão.

$\checkmark$ Zona de Produção Agrícola Familiar - Zona 6: é composta por pequenas e médias propriedades rurais baseadas na agricultura familiar, com tradições culturais e estrutura produtiva diversificada, tendo como objetivo garantir a produção agrícola de pequena e média escala. Esta zona é região de nascentes do Ribeirão dos Negros, do Quilombo e do Pântano.

$\checkmark$ Zona de Uso Predominantemente Agrícola - Zona 7: tem como características a grande diversidade de produção agrícola e de agroecossistemas; abundância de recursos hídricos; diversidade de solos e de estrutura fundiária; predomínio das redes agroindustriais: sucroalcooleira, citrícola, láctea, de carne bovina e de avicultura de corte; áreas com grande 
potencial de lazer e turismo, com chácaras de recreio, cachoeiras, propriedades históricas e o Vale do Quilombo; abrange o Distrito de Santa Eudóxia. Há presença de parcelamentos clandestinos ou irregulares.

\section{Áreas de Especial Interesse Ambiental}

As Áreas Especiais de Interesse Ambiental são porções do território destinadas a proteger e recuperar os mananciais, nascentes e corpos d água; a preservação de áreas com vegetação significativa e paisagens naturais notáveis; áreas de reflorestamento e de conservação de parques e fundos de vale. São destacadas aqui somente as áreas de interesse hidrológico:

$\checkmark$ Do Córrego Mineirinho ao Bosque Santa Fé, nas Zonas 1 e 2;

$\checkmark$ Do Córrego do Cambuí ao bairro Santa Paula, nas Zonas 1, 2 e 4;

$\checkmark$ Dos Córregos do Gregório,Lazzarini e Sorregotti, nas Zonas 1 e 2;

$\checkmark$ Do Córrego do Tijuco Preto, nas Zonas 1 e 2;

$\checkmark$ Do Córrego São Rafael, nas Zonas 3B e 5A;

$\checkmark$ Do “Conjunto Habitacional Dom Constantino Amstalden” ao Córrego do Monjolinho, na Zona 3B;

$\checkmark$ Do Córrego da Água Fria, na Zona3, excluindo-se a área do CEAT - Centro Empresarial de Alta Tecnologia “Dr. Emílio Fehr” e suas futuras ampliações, a serem definidas por Lei específica.

\section{Coeficientes de ocupação}

O Plano Diretor de São Carlos, além de zonear o território municipal, impondo usos proibitivos em determinadas áreas, estabelece também coeficientes máximos de ocupação, aproveitamento, permeabilidade e de cobertura vegetal. Esses coeficientes influenciam de forma direta o coeficiente de impermeabilização e, por conseguinte, o coeficiente de escoamento superficial, os volumes e as velocidades de escoamento superficial na bacia hidrográfica.

Coeficiente de ocupação: é a relação existente entre a área de projeção da edificação no solo e a área do terreno.

Coeficiente de aproveitamento: é a relação entre a área edificável e a área do terreno. Subdivide-se em coeficiente de aproveitamento básico (CAB) e o coeficiente de aproveitamento máximo (CAM), onde CAB é a relação entre a área edificável básica e a área 
do terreno e CAM é o fator pelo qual a área do lote deve ser multiplicada para se obter a área máxima de edificação permitida neste mesmo lote.

Coeficiente de permeabilidade: é a relação existente entre a área permeável e a área do terreno.

Coeficiente de cobertura vegetal: é a relação entre a área coberta por vegetação arbórea ou arbustiva de um determinado imóvel e a sua área total. É aplicado somente em áreas de mananciais.

A cada zona do município são atribuídos valores específicos para esses coeficientes, dependendo das especificidades da área. O Plano Diretor estabelece áreas também que exigem tratamento especial por destacar determinadas especificidades ou cumprir funções especiais no planejamento e no ordenamento do território, complementando o zoneamento por meio de normas especiais de parcelamento, uso e ocupação do solo. São as chamadas Áreas de Especiais Interesses (AEI) e classificam-se em: AEI histórico; ambiental; turístico, histórico e ecológico; turístico, esportivo e ecológico; industrial; de transporte aéreo; social. (PMSC, 2013).

A localização do sistema de drenagem fluvial de acordo com cada zona delimitada pelo plano diretor do município e seus coeficientes de ocupação (CO), coeficiente de aproveitamento (CA) e coeficiente de permeabilidade (CP) é apresentado no Quadro 1.

\begin{tabular}{|c|c|c|c|c|}
\hline Zonas & Córregos & CA & CO & $\mathbf{C P}$ \\
\hline $\begin{array}{l}1 \text { - Zona de Ocupação } \\
\text { Induzida }\end{array}$ & $\begin{array}{l}\text { Córrego do Gregório, Córrego do Monjolinho, } \\
\text { Córrego do Tijuco Preto, Córrego do Cambuí }\end{array}$ & 1,4 & $70 \%$ & $15 \%$ \\
\hline $\begin{array}{l}2 \text { - Zona de Ocupação } \\
\text { Condicionada }\end{array}$ & $\begin{array}{l}\text { Córrego da Fazenda Rancho Alegre, Córrego do } \\
\text { Gregório, Córrego do Sorregotti da Invernada, } \\
\text { Córrego Santa Maria do Leme }\end{array}$ & 1,4 & $70 \%$ & $15 \%$ \\
\hline $\begin{array}{l}3 \text { A }- \text { Zona de } \\
\text { recuperação e ocupação } \\
\text { controlada }\end{array}$ & Córrego da Água Quente & $1-$ & $70 \%$ & $15 \%$ \\
\hline $\begin{array}{l}3 \quad \text { B } \quad \text { Z Zona de } \\
\text { recuperação e ocupação } \\
\text { controlada }\end{array}$ & $\begin{array}{l}\text { Córrego Ponte de Tábua, Córrego do Monjolinho, } \\
\text { Córrego São Rafael }\end{array}$ & 1,4 & $\begin{array}{l}50- \\
70 \%\end{array}$ & $\begin{array}{l}15- \\
30 \%\end{array}$ \\
\hline $\begin{array}{l}5 \text { A - Zona de Proteção } \\
\text { e ocupação restrita }\end{array}$ & Córrego do Espraido, Córrego da Martinha & & & \\
\hline Entre as Zonas & $\begin{array}{l}\text { Córrego Santa Fé, Córrego do Mineirinho, Córrego } \\
\text { do Monjolinho, Córrego do Tijuco Preto }\end{array}$ & & & \\
\hline
\end{tabular}

Fonte: Adaptado de PMSC (2005)

\section{Os instrumentos de política urbana}

Os instrumentos da política urbana contemplam: 1 - a utilização, edificação e parcelamento compulsórios; 2 - o imposto sobre a propriedade predial e territorial urbana 
progressivo no tempo; 3 - a desapropriação com pagamento em títulos; 4 - o direito de preempção; 5 - o direito de superfície; 6 - a outorga onerosa, que contemplam a outorga onerosa do direito de construir e a outorga onerosa de alteração de uso do solo; 7 - as operações urbanas consorciadas; 8 - o consórcio imobiliário; 9 - a transferência do direito de construir; 10 - o estudo de impacto de vizinhança; e por último a concessão de uso especial para fins de moradia.

\section{Sistema de Gestão e Planejamento do Desenvolvimento Urbano}

O Plano Diretor é parte integrante de um processo contínuo de planejamento e gestão municipal, em que estão assegurados os objetivos e as diretrizes definidas na referida lei, com participação popular na sua implementação ou revisão. Para tanto, compete ao poder executivo municipal articular e promover os canais democráticos de participação da sociedade civil na discussão e formulação de diretrizes da política urbana.

O sistema é um processo interativo dos diversos órgãos e setores da administração municipal e compete ao poder executivo criar o Conselho Municipal de Desenvolvimento Urbano, contemplando a participação do poder público e da sociedade civil como um órgão de caráter consultivo, fiscalizador, de acompanhamento e de assessoramento em relação às políticas urbanas.

São previstas nesta lei a criação do Fundo Municipal de Habitação e Desenvolvimento Urbano, destinado a propiciar apoio e suporte financeiro à consecução da política municipal de desenvolvimento urbano e habitação de interesse social, organizando a captação, o repasse e a aplicação de recursos, e a criação do Grupo Especial de Análise GEA, composto por servidores públicos com qualificação técnica, a fim de assessorar a administração municipal (PMSC, 2013).

\subsection{Plano Diretor de drenagem ambientalmente sustentável do município de São Carlos}

O Plano Diretor de Drenagem Urbana Ambientalmente Sustentável do Município de São Carlos foi elaborado em 2011 para fornecer diretrizes e auxiliar a prefeitura municipal a gerenciar a drenagem urbana do município, de modo a subsidiar a tomada de decisão quanto a redução dos impactos causados pelas inundações.

Na elaboração do plano foram estudadas as condições atuais da drenagem urbana para elaborar um diagnóstico da rede de drenagem de São Carlos e formular prognósticos para condições de ocupação de uso e ocupação do solo futuras. 
O plano propõe a adoção de medidas estruturais e não estruturais de controle de inundação. Dentre as medidas estruturais, são propostas a construção de 21 barragens de detenção in-line, com objetivo de amortecer as vazões veiculadas pelos córregos do Douradinho, Ponte de Tábua, Monjolinho, Santa Maria Madalena, Tijuco Preto, Paraíso,Mineirinho, Gregório, Sorregotti, Lazzarini, Medeiros, Água Quente e Água Fria. São previstas também a canalização de trechos do Córrego do Gregório e do Monjolinho. A localização dos córregos pode ser visualizada no Anexo A.

Dentre as medidas não estruturais, destacam-se a obtenção de recursos financeiros, treinamento dos técnicos envolvidos na gestão da drenagem urbana, educação ambiental, orientação para projetos de engenharia e a elaboração de um manual de drenagem urbana (PMSC, 2011).

\subsection{Conceitos Relativos ao Controle de Enchentes}

As tecnologias alternativas ou técnicas compensatórias de drenagem como conceito de controle de enchentes buscam minimizar a deficiência dos sistemas convencionais e neutralizar os efeitos da urbanização sobre os processos hidrológicos, com benefícios para a qualidade de vida e preservação ambiental.

De acordo com Baptista, Nascimento e Barraud (2005), essas técnicas atuam na detenção e na infiltração das águas precipitadas, com o intuito de promover o rearranjo temporal das vazões e a diminuição do volume escoado, e assim reduzir a probabilidade de inundações e aumentar a possibilidade de ganhos na qualidade das águas pluviais.

As medidas de controle de enchentes podem ser classificadas, em função do tipo de atuação e da situação da ocupação na bacia hidrográfica atendida. Estas medidas podem ser medidas estruturais e não estruturais.

São consideradas medidas estruturais intensivas quando o homem modifica o rio através de obras hidráulicas como barragens, diques e canalização, entre outros. Estas medidas atuam na aceleração, retardo e desvio do escoamento superficial, reduzindo os riscos de inundação. Essas medidas podem ser divididas em (BAPTISTA; NASCIMENTO e BARRAUD, 2005):

$\checkmark$ Técnicas de controle centralizado: bacias de detenção e retenção;

$\checkmark$ Técnicas de controle na fonte: valas e valetas de armazenamento e/ou infiltração; micro reservatórios individuais; telhados armazenadores também conhecidos popularmente como telhados verdes; e poços de infiltração; 
$\checkmark$ Técnicas lineares: pavimentos porosos, dotados ou não de dispositivos de infiltração; as valas de detenção e/ou infiltração e as trincheiras de infiltração.

As medidas não estruturais acontecem quando o homem convive com o rio. São medidas do tipo preventivas, tais como: zoneamento de áreas de inundação;rede de monitoramento e previsão de alerta ligada a defesa civil; seguros contra inundações; regulamentação do uso e ocupação do solo, através do Plano Diretor; aproveitamento das áreas vulneráveis para usos temporários como, parques, estacionamentos, áreas de lazer, etc.

Segundo Souza (2002), cada novo espaço a ser urbanizado deve compensar seu efeito de ocupação, pois isso representará uma manutenção e recuperação do ciclo hidrológico urbano,para que então a população perceba esse processo e participe de sua manutenção.

O resultado é que a área alterada passa a ter um comportamento similar às condições hidrológicas de pré-desenvolvimento, significando menor escoamento superficial, menores níveis de erosão e de poluição das águas e, consequentemente, menores investimentos para a mitigação de impactos a jusante.

Segundo Urbonas e Stahre (1993), as vantagens de se utilizar esses sistemas de drenagem são: diminuição dos riscos de inundação e melhoria da qualidade do meio urbano e da água; redução ou eliminação do uso da microdrenagem local; boa integração com espaços urbanos e valorização da água no meio urbano; melhoria da recarga de água subterrânea; minimização de intervenções a jusante decorrentes de novos loteamentos; e baixo custo de implantação.

Em relação às desvantagens, os autores citam: utilização de tecnologias limitadas às características do local, tais como: tipo de solo, uso e ocupação, topografia, lençol subterrâneo; manutenção frequente de modo a se evitar perdas e aumentar a vida útil das estruturas; dificuldade de avaliar seu desempenho a longo prazo, devido a aplicação recente e falta de informações a respeito de seu funcionamento; e risco de contaminação do solo e do aquífero.

Para que estas medidas se tornem eficazes, a participação conjunta entre o poder público e a comunidade local é fundamental, de modo que garanta uma convivência tranquila sem prejuízos materiais e, principalmente, perdas humanas. O controle de inundação é eficiente quando há a associação de medidas estruturais e não estruturais.

De acordo com o Ministério das Cidades (2012), as medidas de controle também são associadas quanto à situação de ocupação da bacia hidrográfica, e podem ser: medidas em sub-bacias não urbanizadas; medidas em sub-bacias parcialmente urbanizadas; e medidas em sub-bacias urbanizadas. 
A sub-bacia não urbanizada é considerada quando não houve a ocupação na planície de inundação do curso d’água. Na sub-bacia parcialmente urbanizada a ocupação começa a se consolidar ao longo do curso d’água e haverá necessidade da adoção de medidas de caráter preventivo e emergencial. Já na sub-bacia urbanizada, a ocupação das margens(e mesmo da calha do rio) encontra-se consolidada e, nestes casos, a renaturalização e mesmo uma revalorização ecológica são limitadas, restando intervir a montante do trecho para reduzir os picos de vazão.Assim, são sugeridas adoção das seguintes medidas:

$\checkmark$ Priorizar um plano diretor com o zoneamento da área de inundação visando a estabelecer regras de ocupação de áreas de risco;

$\checkmark$ Revitalizar o curso d'água com recuperação dos taludes e recomposição da vegetação ciliar;

$\checkmark$ Manter o leito em suas condições naturais;

$\checkmark$ Promover o reflorestamento de áreas degradadas para prevenir a erosão e o assoreamento do curso d’água;

$\checkmark$ Estabelecer o zoneamento das áreas não ocupadas e adoção de medidas para que não ocorram ocupações nas áreas de risco;

$\checkmark$ Preservar a faixa "non aedificandi” ao longo dos cursos d’água;

$\checkmark$ Dotar a legislação municipal com instrumento eficaz que promova retenção e a percolação no solo das águas pluviais no perímetro urbano; tais como valos de infiltração e bacias de percolação;

$\checkmark$ Implantar programas de educação ambiental;

$\checkmark$ Instalar pequenos reservatórios em condomínios, parques, e escolas;

\subsubsection{Medidas estruturais de drenagem urbana}

No Brasil as técnicas compensatórias têm sido estudadas principalmente a partir de 1990 por alguns autores. A seguir são apresentadas algumas destas estruturas.

Bacias de detenção são estruturas de acumulação temporária das águas pluviais e dispositivos de armazenamento e regularização do escoamento pluvial afluente. As bacias são utilizadas para atender três funções principais relacionadas à drenagem urbana: o controle de inundações através do amortecimento de cheias geradas no contexto urbano; a redução do escoamento superficial (no caso de bacias de infiltração); e a redução da poluição difusa (URBONAS e STAHRE, 1993; DECHESNE, 2002). 
As valas, valetas e planos de infiltração e/ou detenção são técnicas compensatórias constituídas por simples depressões escavadas no solo e possuem como finalidade armazenar temporariamente as águas pluviais, favorecendo eventualmente a infiltração. As diferenças entre as estruturas são percebidas em suas dimensões, sendo as valas e valetas com dimensões longitudinais maiores que transversais. Já os planos possuem pequenas profundidades e as dimensões longitudinais não muito maiores do que as transversais (ALMEIDA, NASCIMENTO e BAPTISTA, 2005).

Os telhados de armazenamento representam uma das possibilidades para redução do escoamento das águas das chuvas por meio do armazenamento provisório em sua própria estrutura, com limitação de descarga de vazão máxima por reguladores de vazão. Nesta técnica pode-se adotar tanto telhados planos como dotados com inclinação de 5\%, dependendo de instalação de compartimentos (BAPTISTA, NASCIMENTO e BARRAUD, 2005).

Os micro reservatórios ou reservatórios individuais são pequenas estruturas de amortecimento de cheia que permitem retardar o escoamento e atenuar os picos de cheia, possibilitando assim, a recuperação da capacidade de amortecimento da bacia perdida pelo processo de impermeabilização da superfície (CRUZ, TUCCI e SILVEIRA, 1998; BAPTISTA, NASCIMENTO e BARRAUD, 2005).

As trincheiras de infiltração são técnicas compensatórias lineares implantadas na superfície do terreno a pequenas profundidades coma finalidade de recolher as águas pluviais e infiltrá-las no solo. Destaca-se também sua utilização na estabilização e atenuação de contaminantes provenientes do escoamento superficial (SCHUELER, 1987; BAPTISTA, NASCIMENTO e BARRAUD, 2005).

O pavimento permeável consiste em uma parte da infraestrutura destinada à circulação de pessoas e de veículos, e dispõe de uma camada de base com elevado número de vazios no qual armazena e infiltra as águas pluviais. Essa estrutura é definida como o dispositivo de infiltração que desvia o escoamento superficial para dentro de reservatórios de pedras localizado sob a superfície do terreno (BAPTISTA, NASCIMENTO e BARRAUD, 2005; URBONAS e STAHRE, 1993).

Os poços de infiltração foram estudados por Reis, Oliveira e Sales (2008); Carvalho (2008). Angelini Sobrinha (2012) avaliou a eficiência do volume escoado de um poço de infiltração construído em escala real no campus da Universidade Federal de São Carlos - SP. Este sistema teve eficiência de $100 \%$ na redução do volume e pode ser aplicado em lotes urbanos onde ainda não existam sistemas de drenagem convencionais, em substituição a este. 
Outros autores que desenvolveram estudos acerca das técnicas compensatórias de drenagem são: Baptista, Nascimento e Barraud (2005); Almeida, Nascimento e Baptista (2005); Daywater (2003); Deschene (2002); Matos, (2000); Butler e Davies (2000); US-EPA (1999); Cruz, Tucci e Silveira, (1998); Barraud et al., (1999); STU e Agences de l'Eau (1994); Urbonas e Stahre (1993); STU (1991); e Schueler (1987).

\subsection{Estudos hidrológicos}

Em virtude da carência de dados fluviométricos que poderiam subsidiar análises estatísticas de cheias, nos estudos hidrológicos voltados à drenagem urbana, normalmente são adotados modelos matemáticos do tipo chuva-vazão para a definição dos hidrogramas de projeto. Com relação aos dados pluviométricos, estão disponíveis para as principais cidades do país as relações IDF (intensidade-duração-frequência).

Entretanto, na desagregação dessas precipitações para a determinação dos ietogramas reside o grande problema do hidrólogo, visto que para cada distribuição temporal das chuvas tem-se hidrogramas diferentes.

Segundo Canholi (2005) em reservatórios de amortecimento de cheias, quando, além da correta estimativa do pico da vazão, também é necessário a determinação dos volumes associados, os estudos para a definição dos hidrogramas de projeto exigem uma análise mais profunda dos mecanismos climatológicos que influenciam a desagregação das precipitações e das durações críticas.

Assim, nos projetos de obras de reservação de deflúvio é fundamental a definição do ietograma e do volume de deflúvio, e não apenas a determinação da intensidade média e do pico de vazão, muitas vezes suficientes para o dimensionamento de canais. Dessa forma, na inexistência de registros históricos de precipitação, buscam-se informações generalizadas que podem ser utilizadas como base adequada para o projeto (CANHOLI, 2005).

\subsubsection{Precipitações}

As chuvas frontais ou ciclônicas originam-se do contato entre massas de ar quente e frias. As massas de ar quente são elevadas (menor densidade), encontrando condições de temperaturas e pressão menores, que facilita a condensação da umidade existente. Essas chuvas apresentam baixa intensidade e grande duração. Atingem grandes áreas, sendo, por isso, causadoras de inundações em grandes bacias hidrográficas (TUCCI, 1995). 
As chuvas orográficas são consequência de ventos úmidos que se deslocam verticalmente devido a barreiras montanhosas. São chuvas que podem ter de pequena a grande intensidade, pois o mecanismo de produção pode estar associado aos outros tipos de chuva. Caracterizam-se por serem muito frequentes.

As chuvas convectivas ou de verão são formadas por um processo de convecção da massa de ar úmido, que se forma em uma região restrita, em função de um gradiente de temperatura vertical. Durante a manhã, a radiação solar aquece a massa de ar e o solo. No período da tarde, com a diminuição da radiação solar e com uma radiação da massa de ar em contato com o solo, em função do calor nele armazenado, cria-se uma situação de instabilidade. Essas chuvas possuem, geralmente, grande intensidade e curta duração e atingem áreas restritas. São, portanto, causadoras de inundações em pequenas bacias urbanas. (TUCCI, 1995).

\subsubsection{Ietograma de projeto}

O ietograma de projeto indica como um evento de precipitação pode estar distribuído no tempo. O conhecimento da distribuição temporal da chuva é de extrema importância, já que esta pode influenciar significativamente na magnitude do hidrogramas de saída.

Uma precipitação com pico de intensidade concentrada no final do evento originará um escoamento superficial maior do que outra cuja intensidade máxima se concentre no início do evento (BRANDÃO et. al., 2001).

Portanto, se o pico da precipitação ocorrer no final do evento esta precipitação será igual ao volume de chuva responsável pelo escoamento superficial, uma vez que as perdas iniciais já foram satisfeitas; ao contrário, se o pico da precipitação ocorrer no início do evento, só uma parte desta precipitação gerará escoamento superficial, sendo que o restante irá satisfazer as perdas iniciais e, dessa forma, irá provocar uma vazão menor quando comparado a primeira situação.

\subsubsection{Tormentas padronizadas}

As precipitações intensas são as principais causas de cheias e prejuízos, por isso merecem destaque especial em hidrologia.

Dentro do conceito de chuva intensa, deve ser lembrado que quanto mais curta a duração de uma precipitação, maior a chance de que ela tenha sido muito intensa, e que 
quanto mais frequente uma chuva maior é a probabilidade de sua ocorrência. Assim, na análise de uma chuva intensa, deve ser considerada a inter-relação entre essas variáveis: Intensidade - Duração - Frequência. Esse processo é possível através da utilização das chamadas curvas IDF.

As curvas de intensidade-duração-frequência (IDF) são curvas construídas a partir de registros históricos de alturas de precipitação relacionadas à duração da chuva. As curvas IDF são resultado da tabulação e processamento estatístico desses dados. Vale ressaltar que a composição de ietogramas a partir de curvas IDF pode ser bastante útil para o projetista; porém, com a adoção desse método, ocorre uma maximização das precipitações para cada duração, já que muito raramente os totais precipitados máximos para cada duração ocorrerão em um único evento. (CANHOLI, 2005)

A adoção de chuvas padronizadas é um dos métodos mais utilizados para a definição de chuva de projeto. A chuva de projeto deve ser representativa de muitos eventos e ter as características de intensidade, volume e duração de uma tormenta de mesma frequência.

Ao se adotar chuvas de projetos padronizadas, devem ser consideradas algumas hipóteses: a tormenta de projeto tem um volume equivalente ao de uma chuva observada com a mesma recorrência; a distribuição temporal da chuva adotada é representativa de uma tormenta ocorrida; a chuva é considerada uniformemente distribuída na bacia. (CANHOLI, 2005)

A seguir serão descritos os métodos utilizados para a desagregação de tormentas e composição das chuvas de projeto utilizadas neste trabalho.

\subsubsection{Método dos blocos alternados}

No método dos blocos alternados, a distribuição temporal é conseguida utilizando-se dados das relações IDF. É uma solução simples, que caracteriza uma condição crítica. Este método propõe a distribuição de totais de chuva em intervalos de tempo contidos na duração total. Assim, a partir dos incrementos totais acumulados de precipitação transformados em altura de chuva, os blocos obtidos são rearranjados numa sequência tal que, no centro da duração da tormenta, situe-se o bloco maior e, em seguida, os demais blocos, em ordem decrescente, um à direita e o outro à esquerda do bloco maior, alternadamente (TUCCI, 1995).

De acordo com Canholi (2005), a colocação dos blocos no ietograma é arbitrária e pode conduzir a diversas configurações; porém, existem algumas regras empíricas que devem 
conduzir a picos mais elevados. Uma dessas regras impõe que a parcela mais intensa da precipitação seja colocada entre 1/3 e 1/2 da duração da chuva. Os outros blocos devem ser colocados alternadamente. No método dos blocos alternados, quanto menor o passo de tempo empregado, maiores as intensidades de pico.

\subsubsection{Método de Huff}

O método descrito por Huff (1967) classifica as tormentas em quatro grupos com duração divididas em quatro partes para cada tormenta, chamada quartis. Assim, as tormentas foram classificadas e agrupadas de acordo com o quartil em que a chuva mais intensa ocorreu. Para os dados de chuva de cada quartil, fez-se uma análise estatística, com o objetivo de se obter as curvas de distribuição temporal, associadas a uma probabilidade de ocorrência.

Esta subdivisão foi efetuada de acordo com a localização do pico da precipitação em cada um dos quatro intervalos de tempos iguais em que se pode dividir a duração total de cada acontecimento pluviométrico.

Assim, se o máximo da precipitação em cada um dos intervalos estiver no $1^{\circ}$ intervalo diz-se que o acontecimento pertence ao $1^{\circ}$ quartil, se o máximo estiver no $2^{\circ}, 3^{\circ}$ ou $4^{\circ}$ intervalo o acontecimento pluviométrico pertence respectivamente ao $2^{\circ}, 3^{\circ}$ e $4^{\circ}$ quartil. Se o máximo ocorrer em dois ou mais intervalos, o acontecimento pluviométrico vai pertencer ao quartil onde primeiro se verifica o máximo de precipitação. Os resultados obtidos por Huff são apresentados na Figura 3.
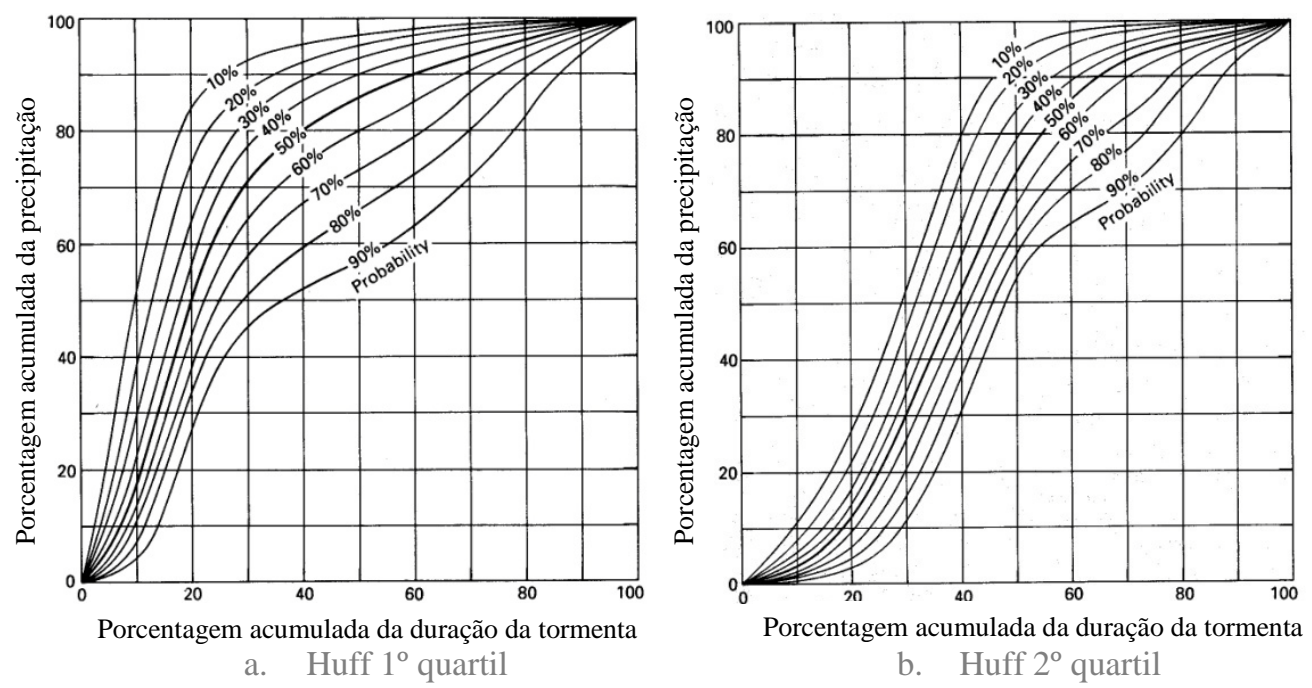

b. Huff $2^{\circ}$ quartil 


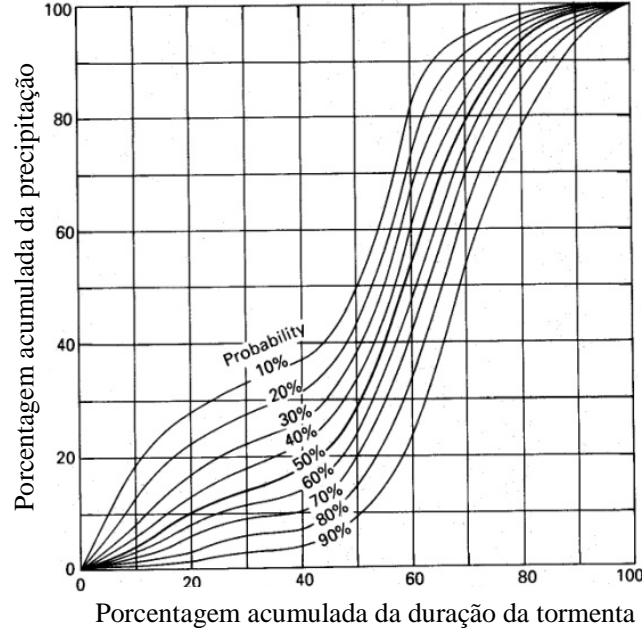

c. Huff $3^{\circ}$ quartil

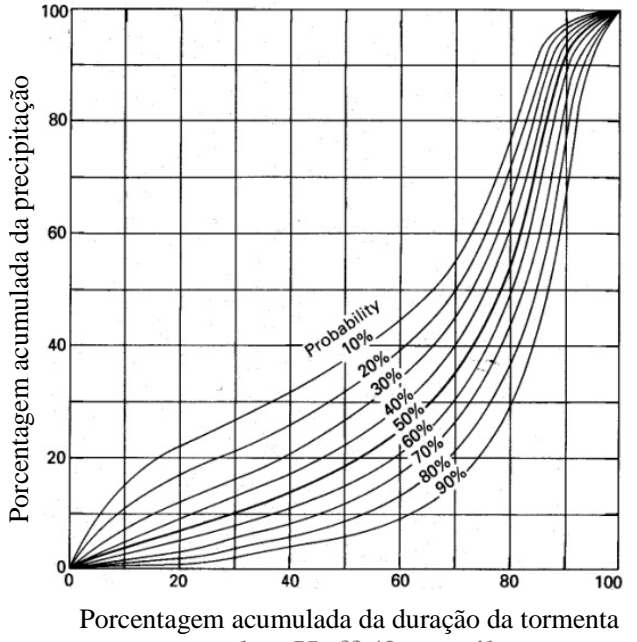

d. Huff $4^{\circ}$ quartil

Figura 3 - Distribuição de Huff nos quatro quartis e probabilidades de ocorrência Fonte: Adaptado de Huff (1967)

A partir das curvas obtidas por Huff apresentadas na Figura 3, é possível estabelecer curvas características para cada tipo de distribuição temporal das chuvas. Na Figura 4, são apresentadas as curvas características para os quatro quartis com 50\% de probabilidade de ocorrências em cada quartil.

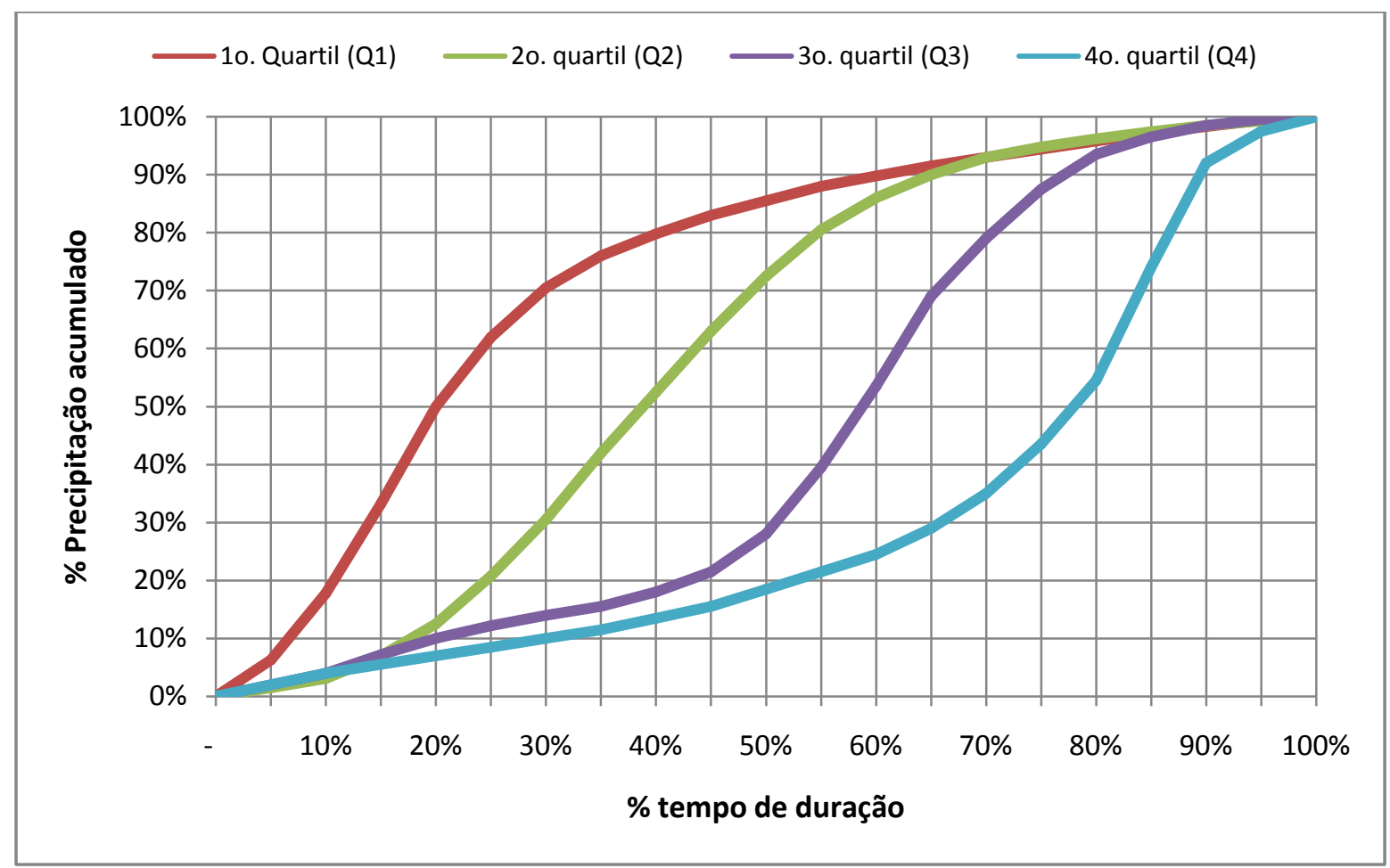

Figura 4 - Distribuição relativa das precipitações em relação ao tempo aos quatro quartis de distribuição pelo método de Huff com 50\% de probabilidade de ocorrência em cada quartil

Como exemplo, utilizando o gráfico de distribuição temporal de chuvas do primeiro quartil pelo método de Huff (Figura 3a), é possível estabelecer, para cada percentual de 
duração de chuva, o percentual de chuva acumulada total e o percentual de chuva acumulado por intervalo de tempo ocorrido. Dessa forma, para uma chuva de $40 \mathrm{~mm}$ e duração de uma hora, o ietograma de projeto que se enquadra no primeiro quartil com $50 \%$ de probabilidade de ocorrência, baseado na Figura 3a, é apresentado na Tabela 2.

Tabela 2 - Percentual de chuva acumulada no tempo para a distribuição de Huff $1^{\circ}$. Quartil com 50 \% de probabilidade de ocorrência

\begin{tabular}{c|c|c|c|c}
\hline $\begin{array}{c}\Delta \mathrm{t} \\
(\mathrm{min})\end{array}$ & $\begin{array}{c}\text { \% de } \\
\text { duração }\end{array}$ & \% acumulada de $\mathrm{P}$ & $\begin{array}{c}\% \text { no } \\
\text { intervalo }\end{array}$ & $\Delta \mathrm{P}(\mathrm{mm})$ \\
\hline 12 & 20 & 50 & 50 & 20 \\
\hline 24 & 40 & 78 & 28 & 11,2 \\
\hline 36 & 60 & 88 & 10 & 4,0 \\
\hline 48 & 80 & 95 & 7 & 2,8 \\
\hline 60 & 100 & 100 & 5 & 2,0 \\
\hline \multicolumn{5}{c}{ Total } \\
\hline
\end{tabular}

Fonte: TUCCI (1995)

Neste método, uma tormenta foi definida como o período de chuva, separada da precipitação que a antecede, por um intervalo de seis horas ou mais. O critério adotado na classificação foi baseado no valor da chuva média da rede de postos pluviométricos e apenas as precipitações que excederam $13 \mathrm{~mm}$ na rede foram adotadas no estudo.

Foram analisadas 261 tormentas em 11 anos de registro, com duração de 30 minutos a 48 horas, de 49 postos espalhados numa área de $1.000 \mathrm{~km}^{2}$. A área considerada no estudo era rural, com terreno plano e com elevações de 200 m a 300 m.As distribuições temporais foram expressas em termos de probabilidade, devido à grande variabilidade existente nas distribuições entre as tormentas.

As precipitações intensas de curta duração, normalmente de maior interesse para os projetos de drenagem urbana, foram classificadas no primeiro quartil (HUFF, 1967).

O método de Huff foi utilizado para a distribuição temporal de chuvas nos estudos hidrológicos para chuvas na região metropolitana de São Paulo, cujos dados observados enquadraram-se com boa correlação à distribuição de Huff $1^{\circ}$ quartil (50\% probabilidade de ocorrência), como mostra a Figura 5 (CANHOLI, 2005; TUCCI, 1995). 


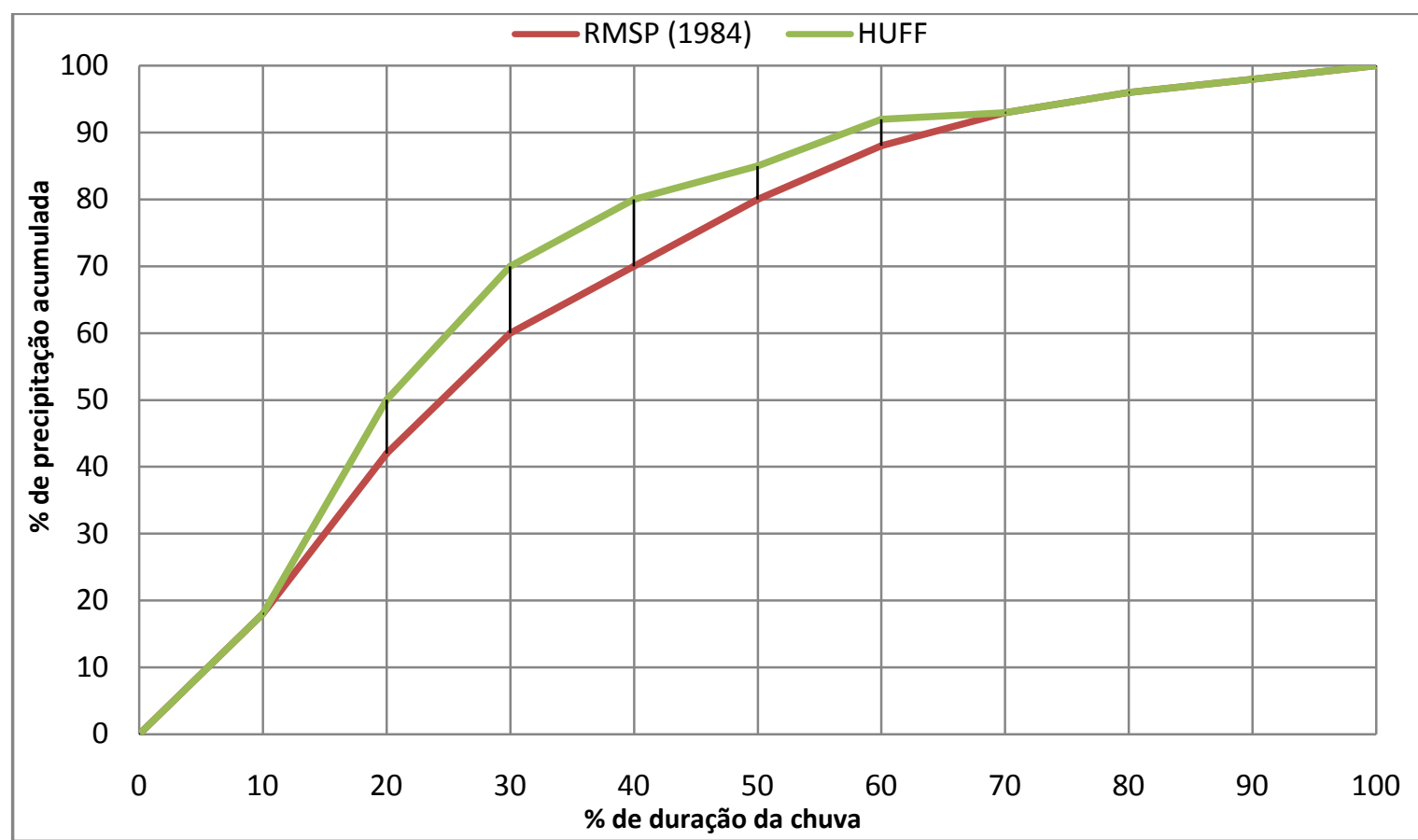

Figura 5 - Comparação entre a chuva observada na região metropolitana de São Paulo em 1983 e a distribuição de Huff $1^{\circ}$ quartil.

Fonte: Adaptado de CANHOLI (2005)

A distribuição das precipitações pelo método de Huff nos quatro quartis é exemplificada na Figura 6. Estas são precipitações de 2 horas de duração e tempo de retorno de 25 anos para a cidade de São Paulo.

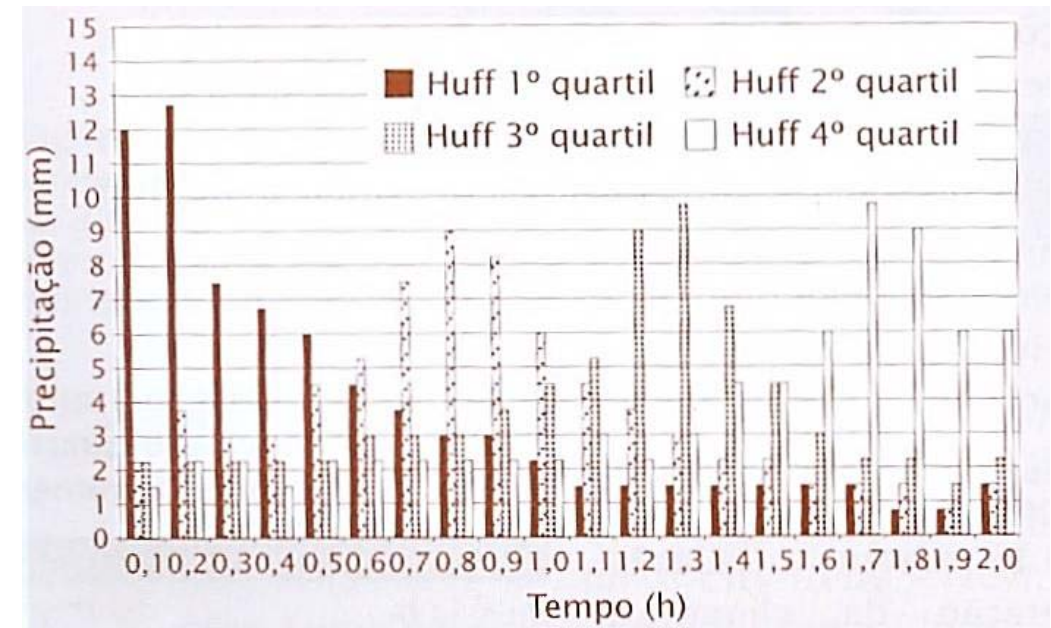

Figura 6 - Distribuição temporais da chuva pelo método de Huff Fonte: CANHOLI (2005)

A relação entre a duração da chuva, frequência e o quartil que melhor representa o fenômeno é apresentada na Tabela 3. Pela Tabela 3, é possível perceber que, na pesquisa de Huff (1967), 66\% das chuvas analisadas com duração menor que 12 horas enquadraram-se no primeiro ou no segundo quartil. 
Tabela 3 - Relação duração da chuva - quartil - frequência

\begin{tabular}{c|c|c}
\hline $\begin{array}{c}\text { Duração da chuva } \\
(\mathrm{h})\end{array}$ & Quartil & $\begin{array}{c}\text { Frequência } \\
(\%)\end{array}$ \\
\hline Menor que 12 & $1^{\circ}$. & 30 \\
\hline Menor que 12 & $2^{\circ}$. & 36 \\
\hline Entre 12 e 24 & $3^{\circ}$. & 19 \\
\hline Maior que 24 & $4^{\circ}$. & 15 \\
\hline
\end{tabular}

Fonte: TUCCI (1995); CANHOLI (2005)

\subsection{Influência da distribuição temporal das chuvas}

Para estudar a influência da distribuição temporal das chuvas, Arnell (1984) apud Canholi (2005) realizou uma análise comparativa entre os volumes de reservação necessários para bacias de detenção em função da chuva de projeto adotada. Em seu estudo, foi realizada a distribuição temporal das precipitações para quatro métodos (Huff $1^{\circ}$ e $2^{\circ}$ quartil, Método de Chicago, e Blocos Alternados), a fim de comparar a forma dos ietogramas para cada método de distribuição espacial da chuva, conforme Figura 7. O estudo mostra que os menores picos de vazão excedente ocorreram para chuvas que se comportam de acordo com a distribuição de Huff $1^{\circ}$ quartil.

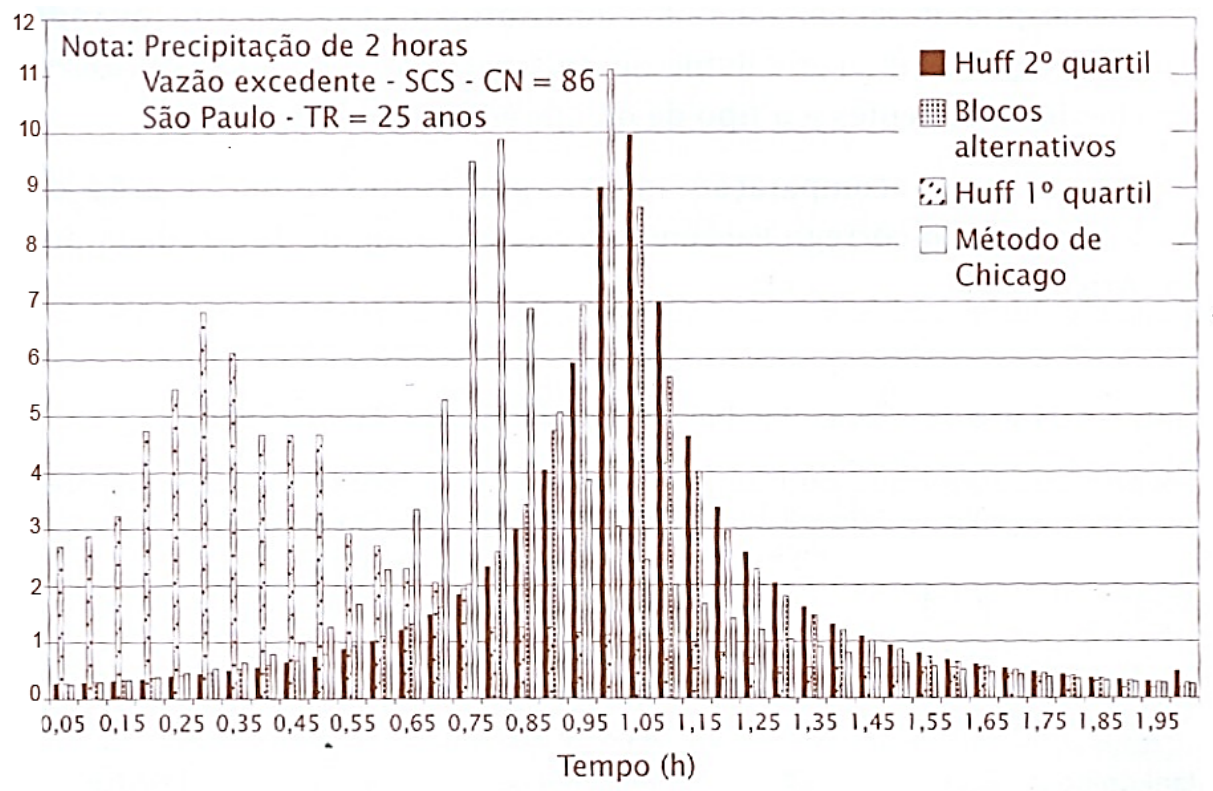

Figura 7 - Comparação entre distribuições temporais de chuva para amortecimento de bacias de detenção Fonte: CANHOLI, 2005

Conte (2001) apud Canholi (2005) apresentou resultados de experiências obtidas na utilização do método SCS com a finalidade de definir diretrizes de projeto em bacias hidrográficas da região metropolitana de São Paulo, recomendado para bacias de drenagem 
entre $1 \mathrm{~km}^{2}$ e $100 \mathrm{~km}^{2}$. Em suas análises, foi adotada a equação IDF para São Paulo com chuva de 2 horas de duração e distribuição temporal de Huff $1^{\circ}$ quartil. Assim, foram calculadas as vazões de pico para áreas densamente povoadas de 1, 5, 10, 25, 50 e $100 \mathrm{~km}^{2}$, conforme Figura 8.

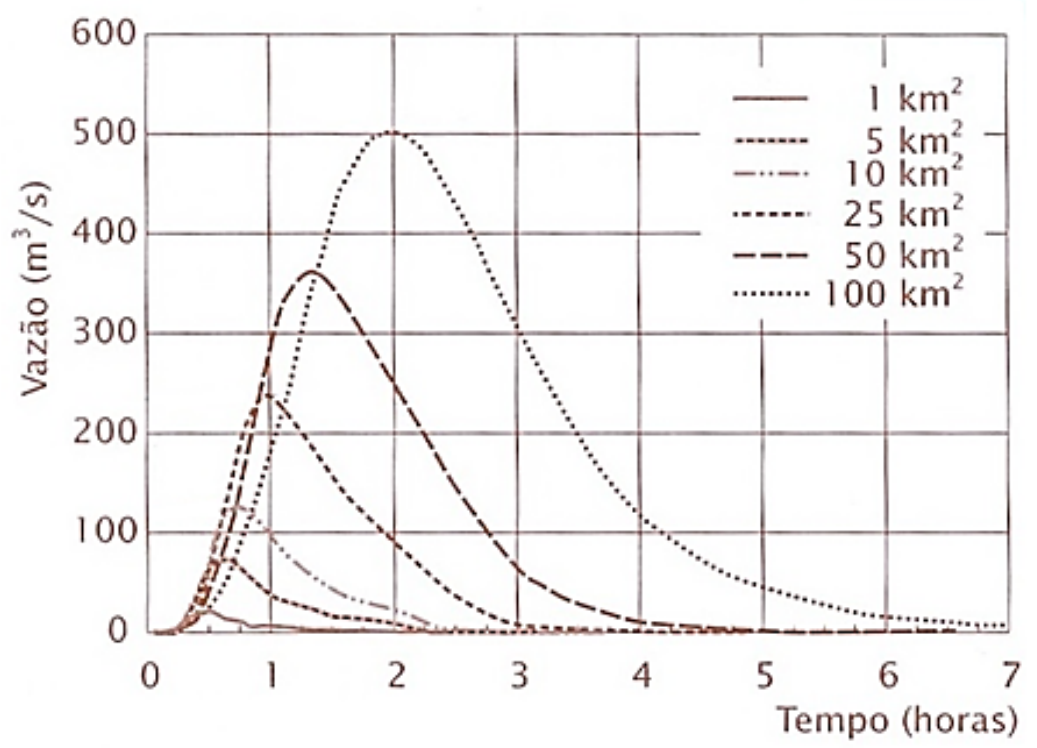

Figura 8 - Hidrogramas característicos para TR=25anos; CN=86; P=75,8mm; e d= 2 horas. Fonte: Conte (2001) apud Canholi (2005)

Para a elaboração de ietogramas de projeto característicos para Portugal, Brandão et al. (2001) aplicaram o método de Huff (1967) em três postos pluviométricos, localizados nas cidades de Lisboa, Évora e Faro em Portugal.Para isso, foram elaborados pelos pesquisadores: Inventário com a lista descritiva das chuvas, com a data, hora de início, precipitação total, intensidade e duração do evento;

Seleção dos eventos intensos, considerados como aqueles com precipitação total superior a $25 \mathrm{~mm}$;

$\checkmark \quad$ Determinação da precipitação acumulada percentual do evento pluviométrico;

$\checkmark \quad$ Subdivisão dos eventos nos quatro quartis de acordo com a metodologia proposta por Huff (1967);

Determinação das probabilidades de excedência com destaque para as probabilidades de $10 \%$, 50\% e $90 \%$ para cada quartil;

Comparação dos resultados com os obtidos por Huff.

Dentre as conclusões dos autores, verificou-se a predominância nas chuvas analisadas de ietogramas tipo Huff do $1^{\circ}$ Quartil, ou seja, ocorrência da maior percentagem da 
precipitação total da chuva no primeiro quarto de duração. As frequências das precipitações ocorridas em cada quartil obtidas pelos pesquisadores são apresentados no Quadro 2.

Quadro 2 - Frequência de precipitações ocorridas em três postos de Portugal e os respectivos quartis de ocorrência

\begin{tabular}{|c|c|c|}
\hline QUARTIL & Postos Pluviométricos & Frequência Relativa (\%) \\
\hline \multirow{2}{*}{$1^{\circ}$ Quartil } & Lisboa & 31,1 \\
& Évora-Cemitério & 30,4 \\
& Faro-Aeroporto & 26,7 \\
\hline \multirow{2}{*}{$2^{\circ}$ Quartil } & Lisboa & 28,0 \\
& Évora-Cemitério & 27,2 \\
& Faro-Aeroporto & 23,0 \\
\hline \multirow{2}{*}{$3^{\circ}$ Quartil } & Lisboa & 19,7 \\
& Évora-Cemitério & 25,0 \\
& Faro-Aeroporto & 24,4 \\
\hline \multirow{2}{*}{$4^{\circ}$ Quartil } & Lisboa & 21,2 \\
& Évora-Cemitério & 17,4 \\
& Faro-Aeroporto & 25,9 \\
\hline
\end{tabular}

Fonte: Adaptado de Brandão et. al (2001)

Foram realizadas também análises das precipitações em relação a sua probabilidade de ocorrência, de modo a comparar os resultados com aqueles obtidos por Huff (1967). Dessa forma, os dados foram analisados estatisticamente para agrupá-los em relação a probabilidade de excedência do evento de 10\%, 50\% e 90\%. Os resultados mostraram boa correlação de dados com relação aos obtidos por Huff. Os resultados para os postos pluviométricos analisados com 10\% de probabilidade de excedência são apresentados na Figura 9. 

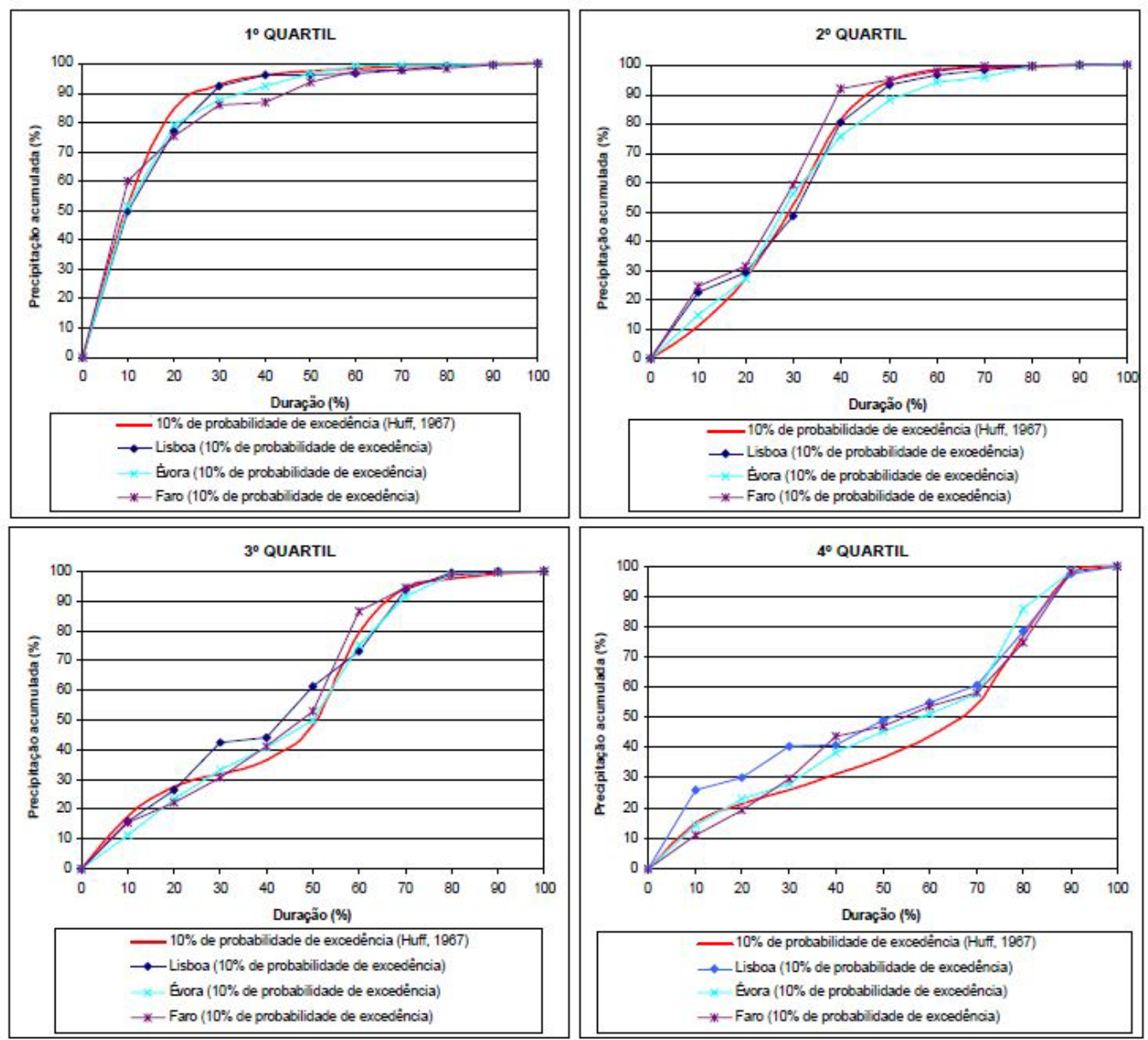

Figura 9 - Resultados obtidos por Brandão et. al (2001) para os postos de Portugal e comparação dos resultados com os obtidos por Huff (1967) com 10\% de probabilidade de excedência

Fonte: BRANDÃO et. al (2001)

Vasconcelos (2007) realizou análise estatística das chuvas baseada no método de Huff para a região do Córrego do Gregório em São Carlos/SP. Foram utilizados dados de uma estação hidrometeorológica próxima ao divisor de águas da bacia e de um pluviômetro às margens do Córrego do Gregório (próximo ao Fórum municipal de São Carlos - SP).

Foram selecionados 71 eventos no período de janeiro de 2004 a Dezembro de 2005, sendo considerados apenas os eventos com precipitação total superior a $10 \mathrm{~mm}$ e de duração entre 45min e 6 horas. Para caracterizar os eventos, foram elaborados gráficos adimensionais de precipitação no tempo para dividir as chuvas nos respectivos quartis.

Os resultados mostraram que $31 \%$ das chuvas pertencem ao grupo do $1^{\circ}$ quartil, $45 \%$ ao grupo do $2^{\circ}$ quartil, $21 \%$ ao grupo $3^{\circ}$ quartil e $1 \%$ ao grupo $4^{\circ}$ quartil. Dessa forma, as chuvas na região situam-se entre o primeiro e o segundo quartil em 76\% das ocorrências.

A lâmina precipitada média foi de 22 mm, com duração de 161min e intensidade de $10 \mathrm{~mm} / \mathrm{h}$.As distribuições adimensionais das chuvas obtidas pelos autores são apresentadas nas Figuras 10 a 13. Nestes gráficos o eixo da abscissa corresponde a proporção do tempo em 
relação a duração total da chuva, e o eixo da ordenada a proporção da precipitação acumulada em relação ao total precipitado.

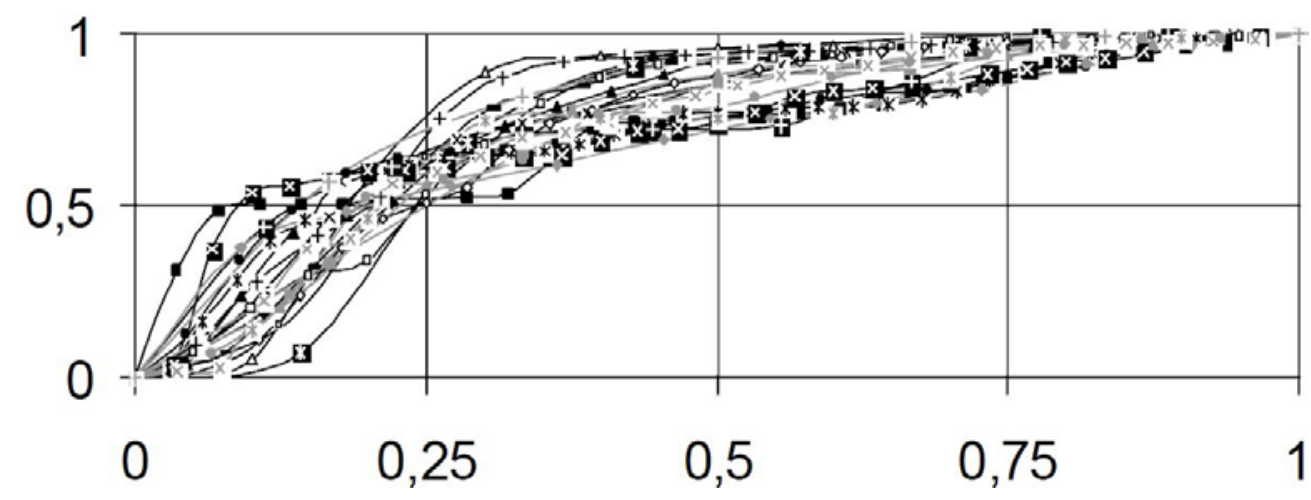

Figura 10 - Resultados dos eventos de precipitação com pico no $1^{\circ}$ quartil para chuvas localizadas no Córrego do Gregório - São Carlos/SP

Fonte: VASCONCELOS (2007)

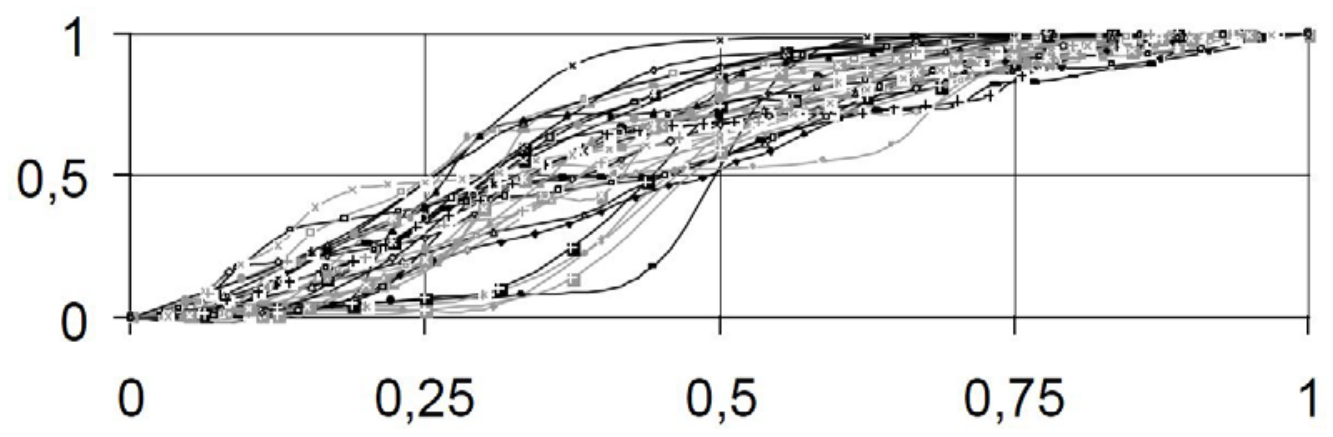

Figura 11 - Resultados dos eventos de precipitação com pico no $2^{\circ}$ quartil para chuvas localizadas no Córrego do Gregório - São Carlos/SP

Fonte: VASCONCELOS (2007)

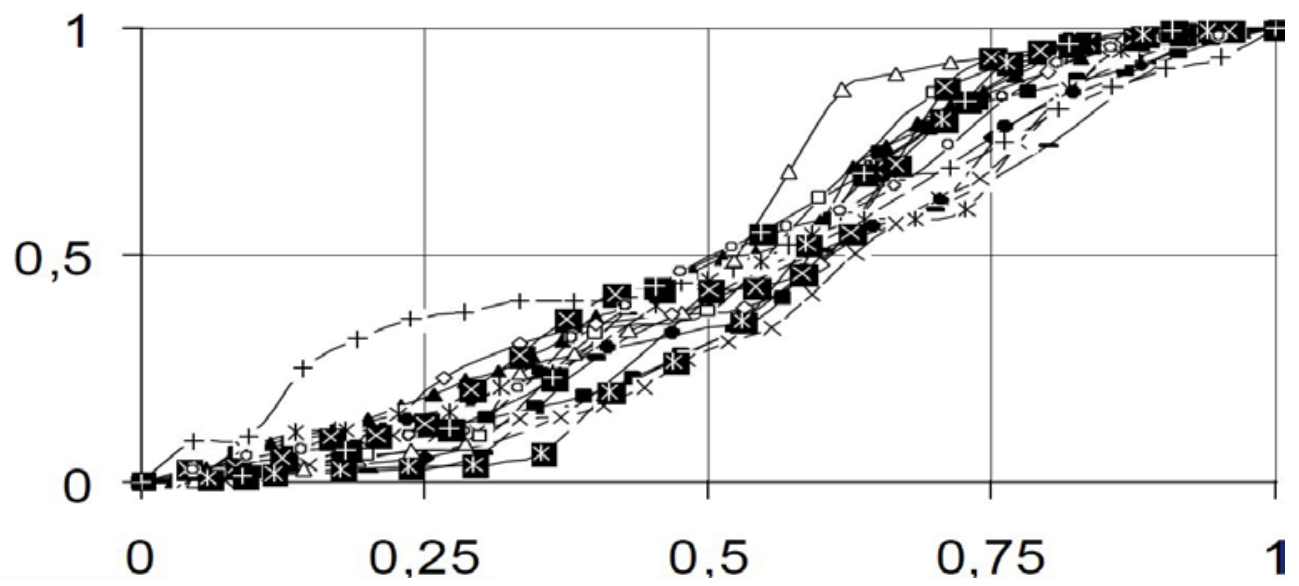

Figura 12 - Resultados dos eventos de precipitação com pico no $3^{\circ}$ quartil para chuvas localizadas no Córrego do Gregório - São Carlos/SP

Fonte: VASCONCELOS (2007) 


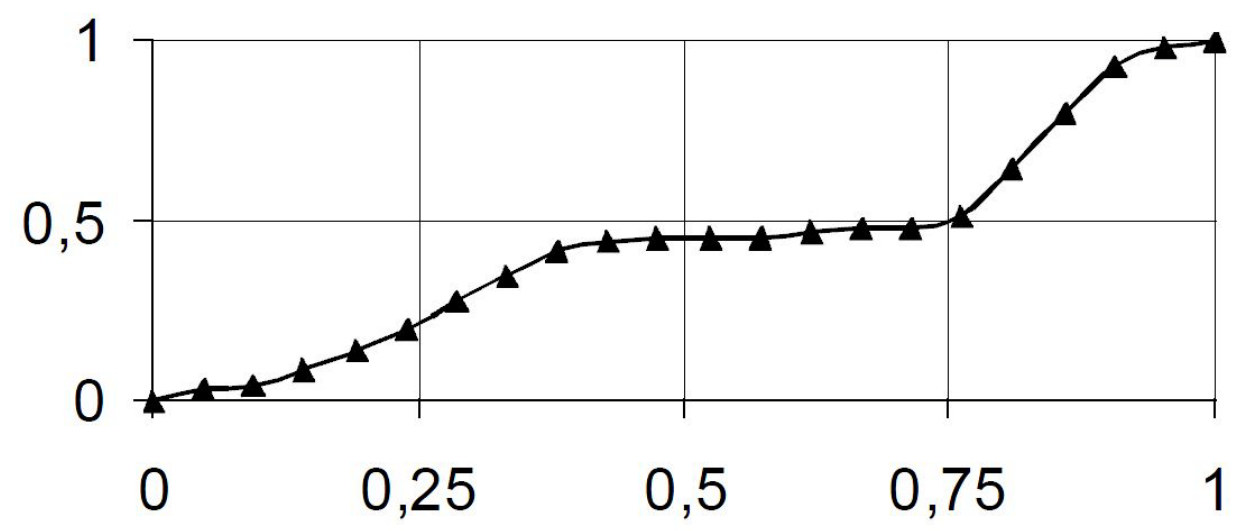

Figura 13 - Resultados dos eventos de precipitação com pico no $4^{\circ}$ quartil para chuvas localizadas no Córrego do Gregório - São Carlos/SP

Fonte: VASCONCELOS (2007)

Dessa forma, em estudos de drenagem urbana em que os eventos de maior impacto são os de curta duração, as contribuições dos autores acerca das distribuições temporais de chuva apontam uma melhor representatividade dos resultados utilizando-se do método de Huff para o $1^{\circ}$ quartil, como evidenciado por Vanconcelos (2007) para o Córrego do Gregório em São Carlos - SP; Canholi (2005); Conte (2001) para a região metropolitana de São Paulo; Brandão et al. (2001) para cidades de Portugal; e Arnel (1984).

\subsection{Ferramentas de simulação hidrológica}

A plataforma HEC, desenvolvido pelo Hydrologic Engineering Centre, do Corpo de Engenheiros do Exército dos EUA (US Army Corps of Engineers) é uma plataforma capaz de simular os processos chuva-deflúvio em bacias hidrográficas dendríticas e dispõe de módulos hidráulicos e hidrológicos para simulação, entre os quais os mais importantes são o módulo HEC-RAS- hidráulico e o módulo HEC-HMS- hidrológico(USACE, 2004).

O módulo HMS (Hydrologic Modeling System) simula vários processos hidrológicos, entre eles, destaca-se o processo de transformação chuva-vazão em bacias hidrográficas urbanas e rurais.

O módulo RAS (River Analysis System) é um programa aplicado à simulação de perfis de linha de água em rios e reservatórios, na hipótese de fluxo unidimensional e regime de escoamento permanente, gradualmente variado, subcrítico, supercrítico ou misto, bem como em regime não permanente (transiente). Como dados de entrada, são necessárias seções transversais da calha do rio, perfil longitudinal, a definição das condições de contorno e dos coeficientes de rugosidade de Manning e os valores de vazão a serem escoados no trecho. 
O módulo RAS apresenta a vantagem de se comunicar com o software ArcGIS 9.3 através da plataforma HecGeoRas, que permite a retirada de informações necessárias à modelagem hidráulica a partir de modelos digitais de terreno (MDT).

Desse modo, as manchas de inundação podem ser traçadas através do HecGeoRas, utilizando o MDT gerado com as curvas de nível digitalizadas. Para isso, esse suplemento do ArcGIS 9.3 sobrepõe os níveis de água simulados no software hidráulico Hec-RAS ao modelo de elevação digital do terreno.

\subsection{Economia Ambiental}

A Economia Ambiental é uma corrente metodológica que busca interpretar o problema ambiental e determinar ações que busquem resultados eficientes a partir de considerações acerca das características de tais recursos.

De acordo com Souza (2008), a teoria econômica vem buscando, através de seu arcabouço, determinar formas eficientes e sustentáveis para a utilização dos recursos ambientais. Tais teorias apresentam argumentos sobre o limite, as características, as finalidades dadas aos recursos naturais, entre outros. Todos esses aspectos são de suma importância para a determinação da utilização sustentável dos recursos naturais.

Segundo Romeiro (2001), os recursos naturais nem eram considerados fatores de produção e, portanto, não faziam parte da função de produção. Com o tempo, os recursos naturais passaram a fazer parte da função de produção, mas apenas como fator de perfeita substitutibilidade com os demais fatores de produção (capital e trabalho).

A valoração econômica de ativos ambientais (VEAA) constitui um conjunto de métodos e técnicas cuja finalidade é estimar valores monetários (preços) para bens ambientais. O valor econômico de determinado bem corresponde ao valor que o indivíduo está disposto a pagar por sua existência e por demais benefícios extraídos de sua manutenção e extração (FARIA, 1998).

O valor econômico total (VET) dos ativos ambientais, segundo Tietenberg (2000), pode ser dividido em três componentes:

$\checkmark$ Valor de uso (VU): reflete o uso direto dos recursos ambientais. Tem-se como exemplos: o valor dos peixes retirados dos rios, a madeira retirada da floresta, a água extraída para a irrigação, a beleza de uma cena conferida por uma bela vista.

$\checkmark$ Valor de Opção (VO): reflete a disposição das pessoas a utilizar o recurso no futuro, deixando de utilizá-lo no presente. 
$\checkmark$ Valor de não uso (VNU) ou Valor de existência (VE): tem-se como o valor derivado da satisfação que as pessoas obtêm pelo simples fato de que um recurso natural existe e está sendo preservado.

\subsubsection{Valoração do dano Ambiental}

A necessidade de atribuir o valor de determinado recurso natural e de estimar por meio de uma medida monetária o valor de um dano ecológico é fundamental na medida em que se pretenda compatibilizar o artigo 170 (ordenação econômica) com o artigo 225 (meio ambiente) da Constituição Federal de 1988, disciplinando a apropriação dos recursos (DERANI, 1997).

De acordo Tessler (2004) uma gestão responsável e eficiente dos recursos naturais e a busca de uma poupança ou preservação desses recursos para as gerações futuras só poderá ser alcançada quando forem mais amplamente conhecidos os limites de sua utilização e os custos do consumo de tais recursos.

Benjamin (1998) considera que outra razão para valorar os recursos naturais está fundada no fato da legislação ambiental básica estar centrada no princípio da responsabilidade que impõem a reparação do equivalente após a ocorrência do dano. O próprio princípio do poluidor-pagador obriga ao conhecimento dos custos, dos valores que o poluidor potencial pagará para desenvolver a atividade.

\subsubsection{Métodos de Valoração Econômica Ambiental}

Segundo HANLEY E SPASH (1993), os métodos de valoração econômica ambiental são instrumentos analíticos com aplicações que se expandiram da atividade de recreação ao ar livre para bens públicos tais como vida selvagem, qualidade do ar, saúde humana e estética.

Lezcano (2004) afirma que os métodos de valoração econômica são um conjunto de técnicas que procuram estimar os valores que as pessoas atribuem aos recursos ambientais. De acordo com abordagem proposta por Motta (1997), os métodos de valoração podem ser classificados em métodos de função de produção e métodos de função de demanda. 


\subsubsection{Métodos de função de produção}

Os métodos de função de produção buscam estimar o valor dos recursos ambientais através de uma função de produção que relaciona o impacto das alterações ambientais a produtos com preços de mercado. Estes métodos podem ser aplicados quando o custo, a quantidade ou qualidade de produção de um bem ou serviço privado for afetado pela mudança na qualidade ambiental ou quantidade de recursos naturais. Esta categoria de métodos procura estimar o valor econômico do recurso ambiental a partir de uma função de produção que relaciona o impacto causado na capacidade produtiva ou dos custos de produção de produtos transacionados no mercado (MOTTA, 1997; LEZCANO, 2004).

Para a aplicação destes métodos, é necessário o conhecimento da relação entre a alteração ambiental e o impacto econômico na produção, obtido com base no preço de mercado do produto afetado com base num mercado de bens substitutos (LEZCANO, 2004).

Estes métodos podem ser divididos em dois sub-grupos: método de produtividade marginal e mercado de bens substitutos.

O método de produtividade marginal busca mensurar o impacto causado no sistema produtivo pela variação marginal na provisão de um bem ou serviço ambiental para, a partir desta variação, estimar o valor econômico de uso do recurso ambiental. Este método limita-se a estimar parte do valor dos recursos ambientais, ao captar apenas os valores de uso direto e indireto do recurso ambiental utilizado na produção, sem estimar os valores de opção e de existência em sua função de produção. De acordo com HANLEY e SPACH (1993), as aplicações mais comuns são relacionadas com os impactos da qualidade do ar sobre a produção agrícola e aos impactos da poluição sobre a pesca.

Já o método baseado em mercado de bens substitutos tem como premissa que a perda de qualidade ou escassez do bem ou serviço ambiental irá aumentar a procura por bens substitutos na tentativa de manter o mesmo nível de bem estar da população. Este método procura estimar o valor econômico de um recurso ambiental baseado em mercado de bens substitutos de produtos, sem preço de mercado, cuja função de produção sofre variações ocasionadas pela alteração na disponibilidade ou na qualidade do bem ou serviço ambiental analisado. Sendo assim, o método pressupõe que a alteração na qualidade ou na quantidade de um bem ou serviço ambiental pode induzir o uso de outros bens para realizar substituições deste recurso (LEZCANO, 2004). A grande dificuldade de aplicação deste método está na dificuldade de encontrar na natureza substitutos perfeitos para um o recurso ambiental. Além 
disso, por não computar o valor de existência em sua função, tende a apresentar estimativas abaixo do valor dos recursos estudados.

\subsubsection{Métodos de função da demanda}

Os métodos de função de demanda obtêm o valor dos recursos ambientais com base nas preferências individuais, a partir da disposição a pagar do indivíduo por bens e serviços ambientais, tendo em vista que a alteração na quantidade ou qualidade do recurso ambiental afeta a disposição a pagar ou a receber das pessoas devido às alterações ocorridas com a disponibilidade do recurso ambiental. Assim, estes métodos procuram evidenciar, através das funções de demanda, as preferências individuais por um bem ou serviço ambiental.

Estes métodos podem ser divididos em dois subgrupos: o mercado de bens complementares e os mercados hipotéticos.

O primeiro, formado pelos métodos de preços hedônicos e custo de viagem, procura obter indiretamente a disposição a pagar dos indivíduos recorrendo a mercados de bens ou serviços privados complementares ao recurso ambiental analisado. Enquanto que o segundo, representado pelo método de avaliação contingente, simula um mercado hipotético para tentar captar diretamente a disposição a pagar das pessoas por um bem ou serviço ambiental. (LEZCANO, 2004)

O método de preços hedônicos busca estabelecer uma relação entre os atributos que compõem um bem ou serviço privado e seu respectivo preço de mercado. O método pode ser aplicado a qualquer bem composto privado cujos atributos sejam complementares a bens ou serviços ambientais. Esta metodologia foi utilizada por Lezcano (2004) para avaliação de benefícios econômicos do controle de cheias urbanas, através da captura na variação do preço de um bem imobiliário ocasionada pela ocorrência ou não de inundação no referido imóvel.

Na bacia do Córrego do Gregório, situada em São Carlos-SP, o método foi utilizado por GRACIOSA (2010), que encontrou valores da ordem de $\mathrm{R} \$ 20.000 .000,00$ para toda a bacia do Córrego do Gregório em um cenário atual com tempo de retorno de 100 anos e de R\$ 28.000.000,00 para cenários futuros de ocupação.

O método de custo de viagem estima o valor econômico do bem ou serviço ambiental explorado através dos custos decorrentes da viagem de indivíduos com o propósito de visitar determinado local, geralmente de recreação. Assim, assume-se que o gasto efetuado pelo visitante para se deslocar a um sítio natural refletem a disposição a pagar dos indivíduos pela disponibilidade de visitar o local. São consideradas as despesas efetuadas durante os 
preparativos, no decorrer da viagem propriamente dita, e no próprio local visitado, incluindo transporte, tempo de viagem, taxa de entrada, alimentação e outros. Uma das limitações deste método é a incapacidade de captar valores de não uso dos recursos ambientais, já que o valor atribuído ao local é determinado apenas por aqueles que visitam o local. O método tem sido utilizado para modelar recreação ao ar livre em atividades como pescarias, caçadas, passeios de barco e visitas a florestas (MOTTA, 1997; LEZCANO, 2004).

O método de valoração contingente é baseado em mercado hipotético cujo objeto não pode ser valorado, mesmo que indiretamente, pelo comportamento do mercado. Assim, dada a inexistência de mercados próprios ou relacionados com o recurso ambiental, o valor do recurso ambiental é estimado pela disposição a pagar das pessoas pela disponibilidade ou qualidade de bens ou serviços ambientais.

O método é aplicado através da realização de entrevistas com os indivíduos, os quais devem expressar, em termos monetários, a sua valoração de bens ou serviços ambientais sem preço definido no mercado. A principal fragilidade para se conseguir mensurar o valor monetário do recurso ambiental está na elaboração cuidadosa do questionário a ser aplicado, para que este capte adequadamente as preferências dos consumidores.

Este método foi aplicado em 2004 na bacia do córrego do Gregório por Barros (2005) e Righetto e Mendiondo (2004). As entrevistas foram realizadas após inundação registrada no Gregório em Janeiro de 2004. Os resultados indicam que, para uma inundação em que o nível de água atingiu cerca de 1 metro acima da calha do rio, na região do mercado municipal da cidade, o prejuízo declarado pelos comerciantes do mercado municipal foi de R\$ $500.000,00$.

Machado (2005) desenvolveu curvas de danos por profundidade de submersão devido a enchentes urbanas relacionando características de residências com padrões de ocupação distintos e também para diferentes categorias de comércio e serviços. Para a obtenção das curvas, foram utilizados dados reais de danos aos setores de comércio e serviço e dados sintéticos para a avaliação dos danos às residências e conteúdo dessas.

A metodologia foi aplicada na cidade de Itajubá - MG e utilizou dados de prejuízos de imóveis decorrentes da cheia de janeiro de 2000, por meio de entrevistas. Foram aplicados 469 questionários no setor habitacional e 200 nos setores de comércio, serviços e indústria.

Como resultado, as análises das distribuições de área construída dos imóveis evidenciaram a correlação entre essa variável e o prejuízo dos imóveis decorrentes da cheia em estudo. Esses resultados formaram a base de dados para a construção das curvas de danos 
por profundidade de submersão (DPS), com os valores dos danos expressos em reais por metro quadrado de área construída da habitação $\left(\mathrm{R} \$ / \mathrm{m}^{2}\right)$.

Milograna (2009) elaborou um sistema de auxílio a decisão para a seleção de alternativas de controle de inundações urbanas. A autora utilizou as curvas de danos por profundidade de submerção elaboradas por Machado (2005) para os imóveis residenciais e por meio de entrevistas para os imóveis comerciais para verificar os prejuízos decorrentes de inundações em diferentes cenários para a cidade de Itajubá - MG.

Cançado (2009) desenvolveu metodologia para avaliação do impacto nas edificações e na cidade de Itajubá - MG, de forma a avaliar principalmente os danos indiretos decorrentes de inundações urbanas. Dentre os resultados, está a elaboração de indicadores de vulnerabilidade e de ameaça e exposição das edificações aos danos ao conteúdo em eventos de inundações urbanas.

Na estimativa dos danos, Cançado (2009) utilizou a mediana de área construída dos estabelecimentos comerciais e de serviços pesquisados por Machado (2005) para aplicação na curva de danos por profundidade de submersão elaborado por esta. A autora utilizou para modelação, cenários de tempo de retorno de 5, 25 e 100 anos e encontrou valores entre R\$ 2,2 milhões ( $\mathrm{Tr}=5$ anos) e $\mathrm{R} \$ 10$ milhões ( $\mathrm{Tr}=100$ anos) para, respectivamente 193 e 592 empresas estudadas.

\subsubsection{Microdados Censitários}

O Censo Demográfico é a mais complexa estatística realizada por um país, em que características de toda a população e dos domicílios do território nacional são estudadas. De acordo com o Instituto Brasileiro de Geografia e Estatística (IBGE, 2011), o censo demográfico constitui a única fonte de referência para o conhecimento das condições socioeconômicas da população.

As informações obtidas no censo pelo IBGE (2011) sobre as características dos domicílios e das pessoas provêm de dois questionários: questionário básico, com 37 variáveis, aplicado a todas as unidades domiciliares; questionário da amostra, com 108 variáveis, aplicado aos domicílios selecionados para a mostra. Este questionário contém, além das informações contidas no questionário básico, informações econômicas e demográficas de seus moradores.

Os arquivos com dados agregados por setor censitário são aqueles que abrangem todos os municípios da federação com informações em nível de bairros e distritos municipais. 
Estes foram utilizados inicialmente pelo IBGE como cadastro básico de áreas para a seleção de amostras de pesquisas domiciliares.

Inicialmente, os arquivos com dados agregados por setor censitário eram compostos por variáveis da divisão territorial brasileira e algumas variáveis de porte ou tamanho de setores. A partir do censo demográfico de 1991, foram incorporadas variáveis em nível de setor. Para o censo de 2000, foi criado um primeiro arquivo agregado com base nos dados da sinopse preliminar deste censo. Com a conclusão dos trabalhos, foi produzida uma primeira edição do arquivo agregado por setores censitários, com 527 variáveis sobre características dos domicílios, dos seus responsáveis e das pessoas residentes. Com os dados deste censo, foi criada uma segunda edição com mais de 3200 variáveis.

No censo demográfico de 2010 foi produzido, pela primeira vez na instituição, arquivos com dados em nível de setor censitário. Além das variáveis de identificação geográfica (Grande Região, Unidade da Federação, Mesorregião, Microrregião, Região Metropolitana, Município, Distrito, Subdistrito, Bairro, Setor e Situação do Setor), são distribuídas em planilhas mais de 154 variáveis, que abrangem os domicílios por espécie e as pessoas residentes por sexo e idade. Para tanto, foram utilizados, na presente pesquisa, apenas os dados dos domicílios do tipo particular permanente, que são aqueles domicílios construídos para servir exclusivamente à habitação e com a finalidade de servir de moradia a uma ou mais pessoas.A coleta do Censo Demográfico 2010 foi realizada no período de $1^{\circ}$ de agosto a 30 de outubro de 2010, utilizando a base territorial que se constituiu de 316.574 setores censitários.

O setor censitário é a unidade territorial de controle cadastral da coleta, constituída por áreas contíguas, respeitando-se os limites da divisão político-administrativa, do quadro urbano e rural legal e de outras estruturas territoriais de interesse, além dos parâmetros de dimensão mais adequados à operação de coleta. De acordo com IBGE:

"O setor censitário é a menor unidade territorial, formada por área contínua, integralmente contida em área urbana ou rural, com dimensão adequada à operação de pesquisas e cujo conjunto esgota a totalidade do Território Nacional, o que permite assegurar a plena cobertura do País”. (IBGE, 2011, p.4)

O IBGE disponibiliza um arquivo contendo as variáveis estudadas por setor censitário para cada Unidade da Federação ${ }^{1}$. Este arquivo contém 18 planilhas, das quais foram utilizadas:

${ }^{1}$ Disponível em:

ftp://ftp.ibge.gov.br/Censos/Censo_Demografico_2010/Resultados_do_Universo/Agregados_por_Setores_Censit arios/Base_informacoes_setores_2010_universo_SP_Exceto_Capital.zip 
$\checkmark$ Descrição - O arquivo “Descrição_UF_SP_Exceto_Capital.xls” contém todos os setores censitários do Estado de São Paulo, com o código e a descrição do percurso que abrange todo o perímetro do setor censitário;

$\checkmark$ Básico - O arquivo “Basico_UF_SP_Exceto_capital.xls” contém os códigos e nomes das subdivisões geográficas e a informação básica do cadastro de áreas (totais, médias e variâncias);

Domicilio - Contém três planilhas (Domicilio01_SP.xls; Domicilio02_SP.xls; domicilio_renda_SP.xls) que fornecem informações sobre características dos domicílios, informações sobre seus moradores por sexo, idade, renda e tipo de domicílio;

$\checkmark$ Pessoa - Contém três planilhas (Pessoa11UF.xls a Pessoa13UF.xls), que fornecem informação sobre a população residente por sexo e idade.

Cada linha de cada planilha fornece os dados de um setor censitário e cada coluna corresponde a uma variável, descrita em código numérico, relacionadas ao domicílio, responsável ou pessoa.

Este código numérico contém 15 dígitos divididos da seguinte forma: UFMMMMMDDSDSSSS, em que:

$$
\begin{array}{cl}
\checkmark & \text { UF - Unidade da Federação; } \\
\checkmark & \text { MMMMM - Município } \\
\checkmark & \text { DD - Distrito } \\
\checkmark & \text { SD - Subdistrito } \\
\checkmark & \text { SSSS - Setor }
\end{array}
$$




\subsection{MATERIAIS E MÉTODOS}

A metodologia proposta busca quantificar em valores econômicos a magnitude dos prejuízos ao conteúdo causados pelas enchentes ocorridas em uma área de várzea densamente ocupada da bacia do Córrego do Gregório localizada no centro de São Carlos - SP. Para sua aplicação, foram utilizados:

$\checkmark$ Mapas georreferenciados da área objeto do estudo;

$\checkmark$ Métodos de distribuição temporal de chuvas de Huff $1^{\circ}$ quartil e blocos alternados para análise dos hidrogramas de cheia gerados;

$\checkmark$ Manchas de inundação pelos métodos de distribuição temporal de chuvas aplicado por meio de Sistema de Informação Geográfica (SIG) para simulações de eventos hidrológicos;

$\checkmark$ Cadastramento dos imóveis residenciais e comerciais presentes na mancha de inundação e geração em banco de dados em plataforma SIG;

$\checkmark$ Microdados censitários por setores censitários do IBGE referentes ao relatório do censo 2010 para caracterização das residências;

$\checkmark$ Informações sobre a área dos imóveis contidos na mancha de inundação.

$\checkmark$ Quantificação dos prejuízos nos imóveis cadastrados decorrentes das profundidades de submersão para os cenários estudados pelos métodos de Huff e blocos alternados por meio de curvas de danos por profundidade de submersão.

\section{1. Área de estudo}

A fim de captar os possíveis efeitos das inundações urbanas, foi selecionada uma área com elevada taxa de ocupação do solo, onde se localizam um grande número de domicílios e de empresas. Esta área diretamente impactada situa-se na bacia hidrográfica do Córrego do Gregório na cidade de São Carlos - SP, e representa uma região que sofre inundações frequentes que afetam um importante centro econômico. A área de estudo é apresentada na Figura 14. 


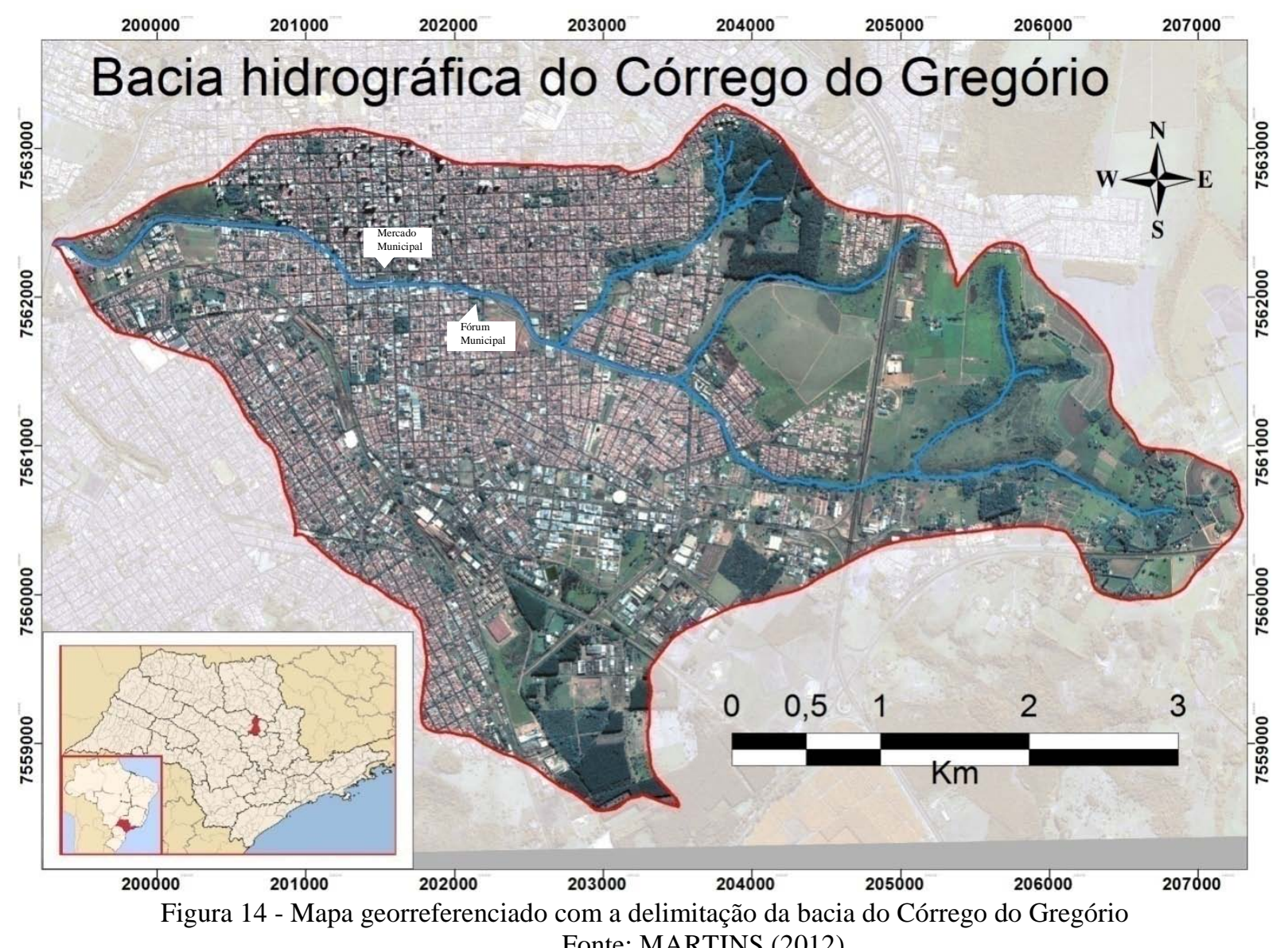
Fonte: MARTINS (2012)

O Córrego do Gregório nasce a leste da cidade de São Carlos, a aproximadamente 900m de altitude e percorre cerca de 7 km até sua foz no Córrego do Monjolinho. O curso de água cruza a área urbana de São Carlos no sentido Leste-Oeste e passa por uma região densamente povoada da região, contida no centro comercial da cidade.

De acordo com Graciosa (2010), a área total da bacia é de 18,93 $\mathrm{km}^{2}$ e possui duas regiões com características distintas: uma urbanizada e outra em processo de urbanização. A região que se encontra em processo de urbanização conta com aproximadamente $10,4 \mathrm{~km}^{2}$ e localiza-se a montante da bacia. Esta parte da bacia apresenta características rurais, sendo que originalmente era ocupada por vegetação de cerrado e atualmente possui sua mata ciliar bastante degradada. A jusante, o processo de urbanização encontra-se mais avançado, no qual contém leito menor ainda com presença de mata ciliar e leito maior ocupado por avenidas marginais.

Já a região urbanizada, compreendida entre a estação hidrometeorológica do NIBH (Núcleo Integrado de Bacias Hidrográficas, do Departamento de Hidráulica e Saneamento da Escola de Engenharia de São Carlos - EESC) e a foz no Rio Monjolinho, sofre 
frequentemente com problemas de inundação, principalmente no trecho entre o Fórum e o Mercado Municipal.

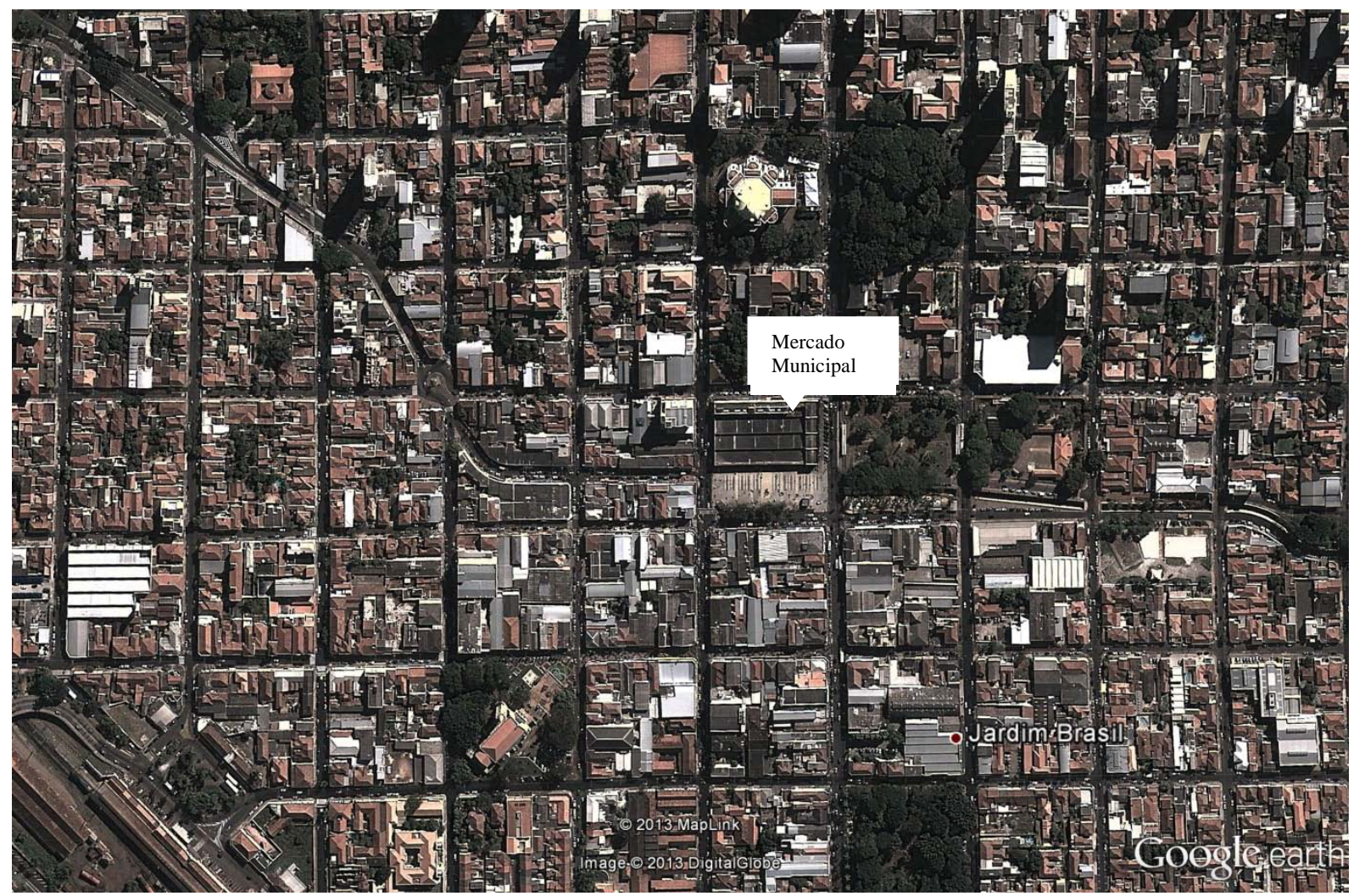

Figura 15 - Localização da região urbanizada de São Carlos incidente de inundações analisadas neste estudo

De acordo com Graciosa (2010), uma série de intervenções no canal principal, como retificação de seção, estrangulamento por pontes, alterações na geometria e revestimento do canal, levaram a modificações no sistema de equilíbrio natural e agravaram o impacto das enchentes.

De acordo com Souza (2008), a intensa impermeabilização do solo nessa área agrava a situação ao aumentar as vazões de pico, ao diminuir o tempo de concentração da bacia e consequentemente contribuir com os prejuízos causados por eventos hidrológicos severos.

\subsubsection{Delimitação das sub-bacias para obtenção dos CN médios}

A partir dos dados topográficos fornecidos pelo Centro de Divulgação Científica e Cultural (CDCC), do levantamento da rede de microdrenagem feito por Collodel (2009) e da localização dos reservatórios para amortecimento de cheias, previstos no Plano Diretor de Drenagem Urbana Ambientalmente Sustentável do Município de São Carlos (PMSC, 2011), a delimitação das sub-bacias ficou estabelecida com a configuração apresentada na Figura 16. A 
região em que está contida a mancha de inundação simulada neste estudo está contida na subbacia 12.

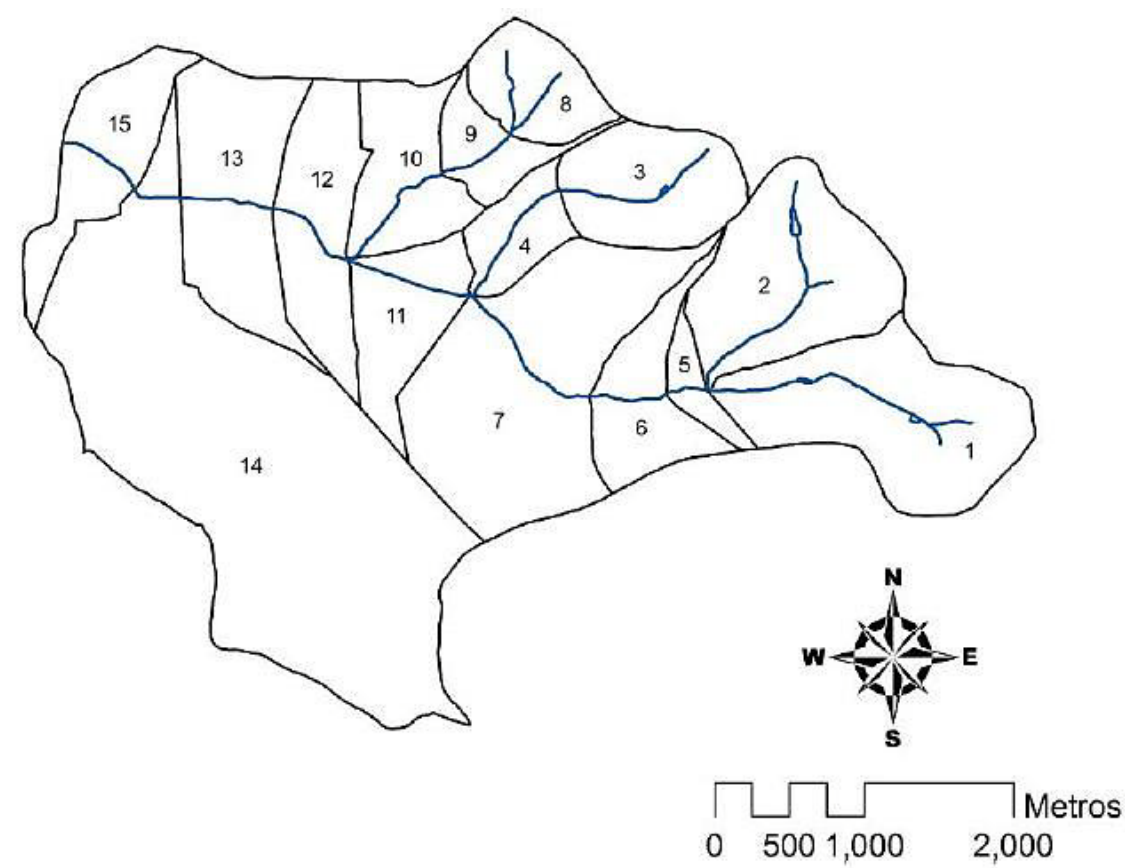

Figura 16 - Configuração das sub-bacias presentes na bacia do Córrego do Gregório Fonte: DECINA (2012)

Para a configuração das sub-bacias, Decina (2012) utilizou dados do levantamento detalhado de toda a rede de microdrenagem da bacia do Córrego do Gregório que indica a localização das bocas de lobo, do trabalho realizado por Collodel (2009) e esta configuração foi utilizada neste trabalho para que a partir disto fossem realizadas outras análises a fim de contribuir com os estudos acerca da bacia do Córrego do Gregório.

\subsubsection{Uso e ocupação do solo}

O processo de delimitação do uso e ocupação do solo foi realizado por Decina (2012) com base em uma imagem do dia 2 de junho de 2011, obtida através do satélite World View 2. O arquivo da imagem contém uma banda pancromática e quatro multiespectrais: vermelho, verde, azul e infravermelho próximo. Para se reconhecer as diferentes feições presentes na bacia do Gregório, foram realizadas composições entre as bandas, as quais passaram por um processo de fusão com a banda pancromática para refinar sua resolução espacial, resultando em pixels de 0,5 m por 0,5 m. Esta etapa foi realizada com o auxílio do software ArcGIS 9.3. O ArcGIS 9.3 também foi utilizado na vetorização manual da imagem de satélite.

A partir da classificação do uso do solo da área de estudo, é possível atribuir um valor de CN médio a cada sub-bacia do sistema. O mapa resultante deste processo de 
geoprocessamento da bacia do Córrego do Gregório pode ser visualizado na Figura 17, onde se vê a delimitação de cada classe.

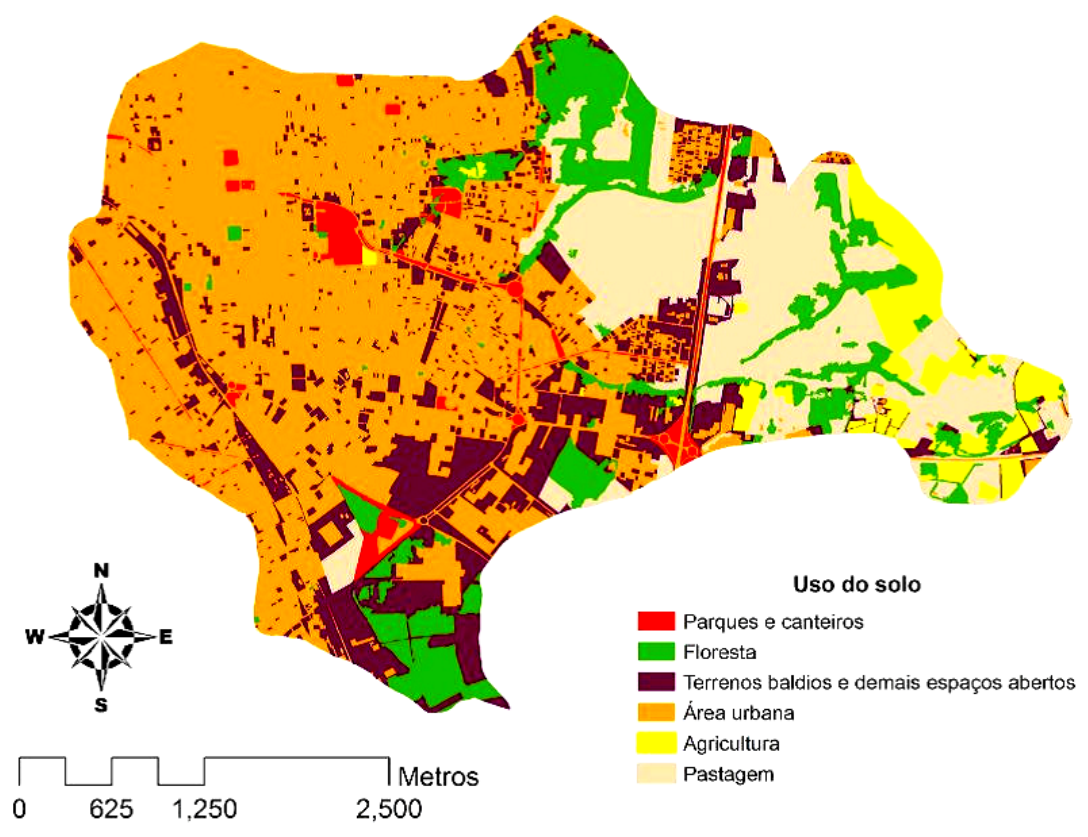

Figura 17 - Uso do solo na bacia do Córrego do Gregório Fonte: DECINA (2012)

\subsection{Tempo de concentração da bacia em estudo}

Os tempos de concentração das sub-bacias foram calculados por meio da fórmula proposta por George Ribeiro (Ribeiro, 1961), expressa por:

Onde,

$$
t_{c}=\frac{16 L_{t}}{(1,05-0,2 p)\left(100 S_{m}\right)^{0,04}}
$$

$\mathrm{t}_{\mathrm{c}}$ : tempo de concentração (min)

$\mathrm{L}_{\mathrm{t}}$ : comprimento do talvegue $(\mathrm{km})$

$\mathrm{S}_{\mathrm{m}}$ : declividade média da bacia $(\mathrm{m} / \mathrm{m})$

p: fração da área da bacia coberta com vegetação (adimensional)

A área de cada sub-bacia e o tempo de concentração nos respectivos cenários são apresentados na Tabela 4. 
Tabela 4 - Tempo de concentração e área das sub-bacias localizadas no Córrego do Gregório

\begin{tabular}{c|c|c|c|c|c|c|c}
\hline \multirow{2}{*}{ Sub-bacia } & \multirow{2}{*}{ Área $\left.\mathbf{( m}^{2}\right)$} & \multicolumn{7}{|c}{ Tempo de Concentração (min) } \\
\cline { 3 - 8 } & & $\mathbf{1}$ & $\mathbf{2}$ & $\mathbf{3}$ & $\mathbf{4}$ & $\mathbf{5}$ & $\mathbf{6}$ \\
\hline 1 & 1.597 .795 & 39,5 & 35,7 & 35,7 & 36,6 & 36,6 & 33,4 \\
2 & 1.349 .366 & 34,2 & 30,6 & 30,6 & 31,4 & 31,4 & 28,7 \\
3 & 865.454 & 21,2 & 18,9 & 18,9 & 19,5 & 19,5 & 18,6 \\
4 & 392.052 & 15,9 & 14,6 & 14,6 & 15,0 & 15,0 & 14,5 \\
5 & 188.991 & 5,0 & 4,4 & 4,4 & 4,6 & 4,6 & 4,3 \\
6 & 645.155 & 9,5 & 8,6 & 8,6 & 8,9 & 8,9 & 8,6 \\
7 & 2.214 .448 & 18,5 & 17,4 & 17,4 & 17,4 & 17,4 & 16,9 \\
8 & 538.384 & 11,5 & 10,1 & 10,1 & 10,4 & 10,4 & 10,0 \\
9 & 363.343 & 9,2 & 8,6 & 8,6 & 8,7 & 8,7 & 8,5 \\
10 & 718.825 & 14,3 & 13,9 & 13,9 & 14,0 & 14,0 & 13,9 \\
11 & 676.579 & 14,0 & 13,6 & 13,6 & 13,7 & 13,7 & 13,6 \\
12 & 899.996 & 10,3 & 10,2 & 10,2 & 10,2 & 10,2 & 10,1 \\
13 & 1.190 .867 & 9,7 & 9,6 & 9,6 & 9,6 & 9,6 & 9,6 \\
14 & 5.038 .564 & 58,4 & 54,8 & 54,8 & 54,9 & 54,9 & 54,6 \\
15 & 765.842 & 9,4 & 9,3 & 9,3 & 9,3 & 9,3 & 9,3 \\
\hline
\end{tabular}

Foi utilizado neste trabalho o maior tempo de concentração da bacia dentre os cenários propostos, o qual foi estabelecido por Decina (2012) em 120 minutos.

\subsection{Curva IDF}

Foi utilizada acurva IDF (intensidade-duração-frequência) proposta por Barbassa (1991) para o município de São Carlos - SP. Ela relaciona a intensidade da chuva com a duração e o tempo de retorno, ou seja, o período em que o evento é igualado ou superado. A curva IDF para São Carlos pode ser descrita pela equação a seguir:

$$
i=\frac{1519 \times T^{0,236}}{(t+16)^{0,935}}
$$

Onde:

i é a intensidade média da precipitação ( $\mathrm{mm} / \mathrm{h})$

T é o tempo de retorno (anos)

t é a duração da chuva (min)

As curvas IDF para a cidade de São Carlos com tempo de concentração de 120 min e tempo de retorno de 3, 10, 25, 50, 75, 100 e 200 anos são apresentadas na Figura 18. 


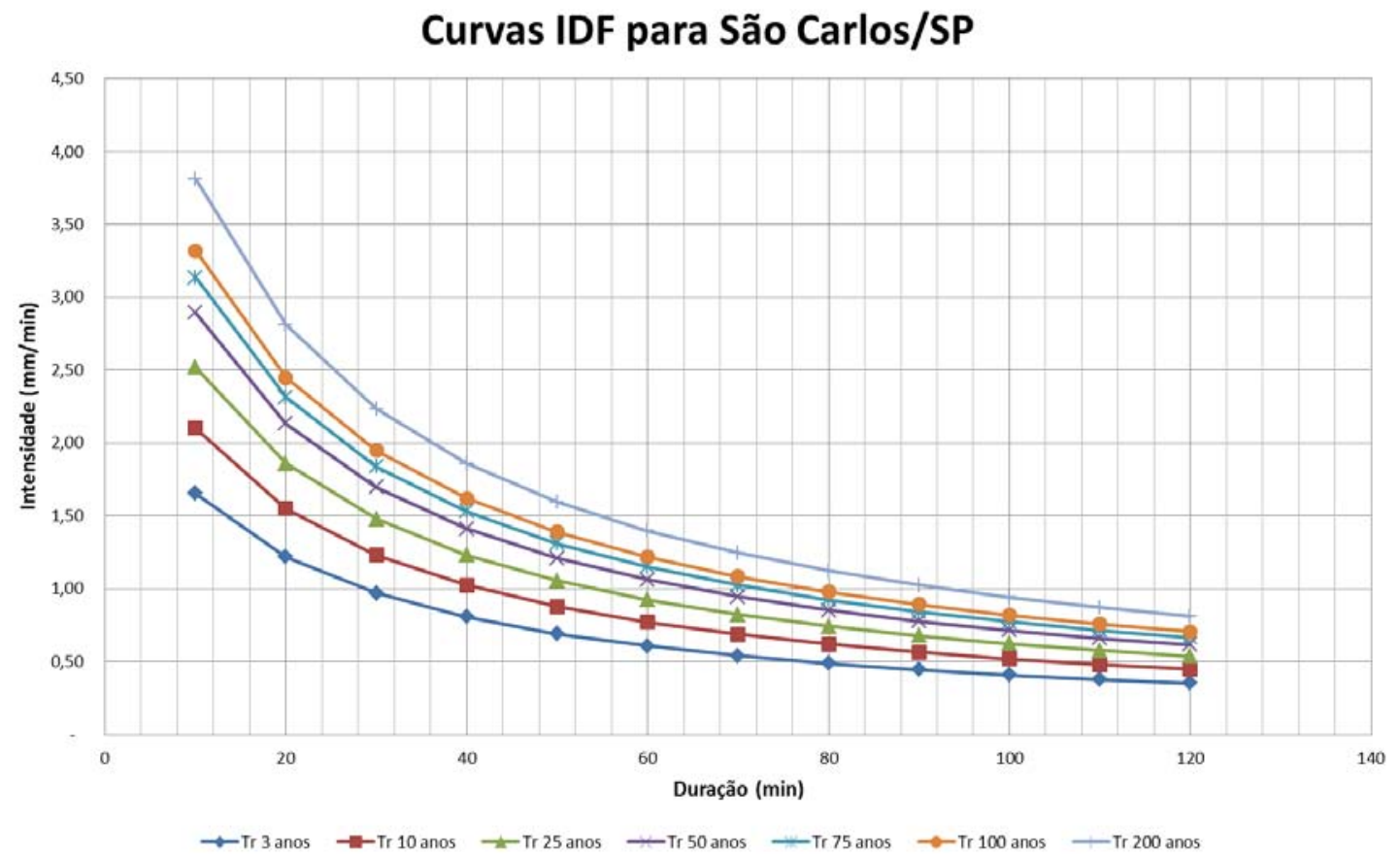

Figura 18 - Curvas intensidade-duração-frequência para o município de São Carlos/SP

\subsection{Simulações hidrológicas}

Foram realizadas simulações utilizando dois métodos de distribuição temporal das chuvas: uma com o pico de intensidade na metade do tempo de duração da chuva, de acordo com a distribuição proposta pelo método dos blocos alternados e outra com o pico no começo da precipitação discretizado sob o mesmo padrão, baseada no método de Huff $1^{\circ}$ quartil. Os dados foram discretizados em 1 (um) minuto para ambos os métodos.

A distribuição das chuvas baseado no método de Huff foi realizada utilizando a metodologia do rearranjo dos blocos alternados, porém com pico no inicio da precipitação e com base em pesquisas realizadas acerca do método de Huff esta distribuição se deu no $1^{\circ}$ quartil entre 10 e 50\% de probabilidade de excedência, como será mostrado na Figura 20.

A distribuição de Huff no $1^{\circ}$ quartil e a distribuição de blocos alternados com pico na metade da duração total da chuva foram utilizadas por mostrar os extremos mais representativos das distribuições temporais das chuvas, já que de acordo com Vasconcelos (2007), 76\% das chuvas ocorridas no Córrego do Gregório estão distribuídas entre o $1^{\circ}$ e $2^{\circ}$ quartil, da mesma forma que as distribuições de chuvas utilizadas neste trabalho, conforme será mostrado na Figura 20.

Tendo em vista que quanto mais próximo o pico da intensidade for do início da precipitação menor será o seu escoamento superficial, essa análise levará a valores de 
escoamento superficial próximos do mínimo para a chuva baseada no método de Huff $1^{\circ}$ quartil (levando em consideração apenas a distribuição temporal da chuva), conforme descrito por Brandão et al., (2001).

Alguns autores possuem contribuições acerca das distribuições temporais de chuva apontam uma melhor representatividade dos resultados utilizando-se do método de Huff para o $1^{\text {o }}$ quartil: Vanconcelos (2007); Canholi (2005); Conte (2001); Brandão et al. (2001); Arnel (1984); e Porto (1967).

\subsubsection{Distribuição temporal da chuva}

Na simulação Huff $1^{\circ}$ quartil e blocos alternados, foram adotados os tempos de retorno de 25, 50 e 100 anos.

A distribuição da chuva pelos dois métodos é apresentada na Figura 19 e os volumes precipitados em cada tempo de retorno na Tabela 5.

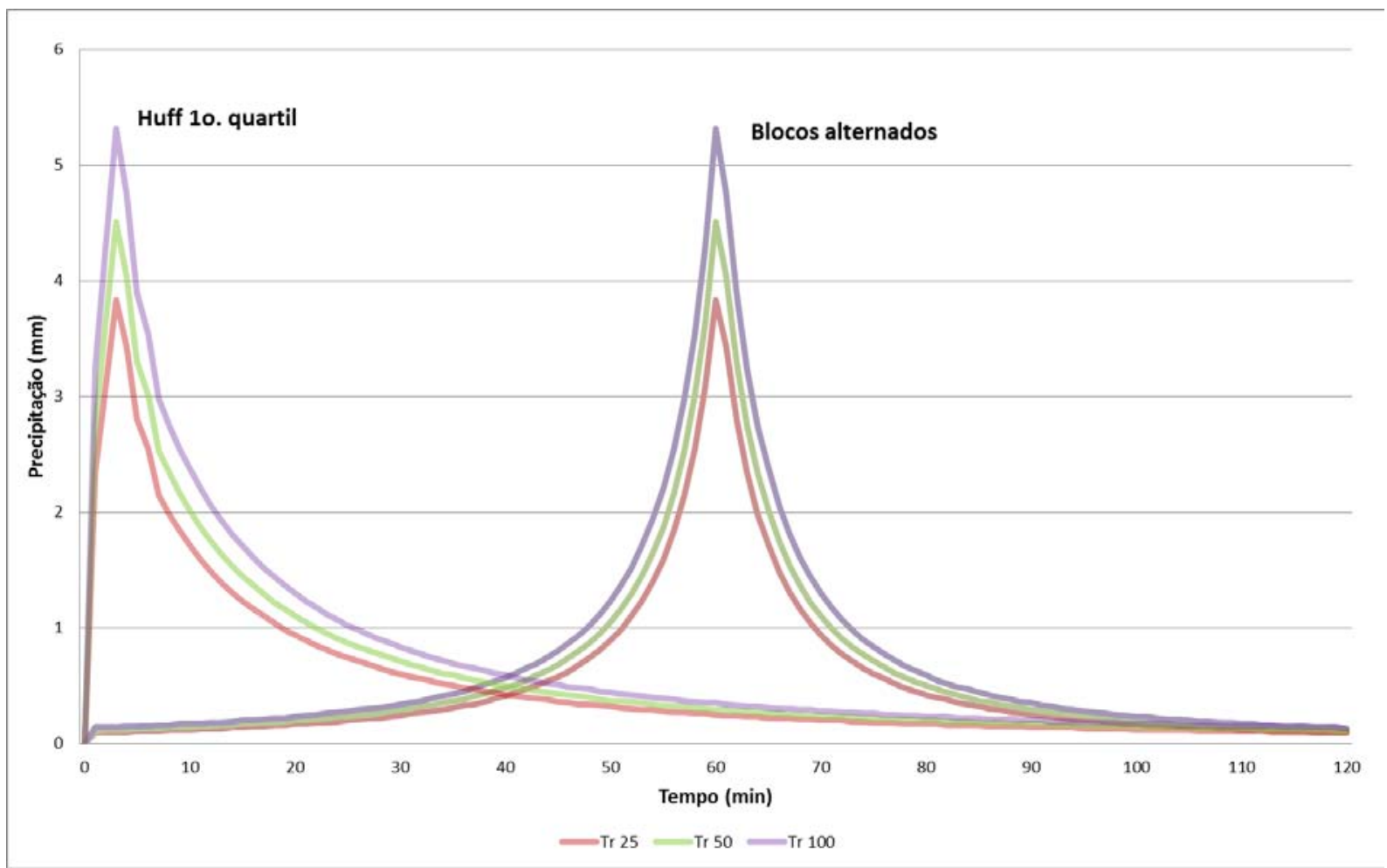

Figura 19 - Distribuição temporal da chuva pelo método dos blocos alternados e Huff $1^{\circ}$ quartil 
Tabela 5 - Volume de chuva precipitado por tempo de retorno de acordo com a curva IDF para o município de São Carlos elaborado por Barbassa (1991)

\begin{tabular}{cc}
\hline \multicolumn{2}{c}{ Volume de chuva } \\
\hline $\begin{array}{c}\text { Tempo de retorno } \\
\text { (TR) }\end{array}$ & $\begin{array}{c}\text { Total precipitado } \\
\text { (mm) }\end{array}$ \\
25 & 65,7 \\
50 & 77,4 \\
100 & 91,1 \\
\hline
\end{tabular}

Para comparar as chuvas de projeto utilizadas neste trabalho com a distribuição de Huff, a chuva foi distribuída no tempo de acordo com o percentual precipitado acumulado total, como realizado por Huff (1967). As chuvas de projeto foram comparadas com aquelas obtidas por Huff na formulação das curvas representativas dos quartis. Dessa forma, a chuva com o rearranjo dos blocos alternados na metade da duração da precipitação e a chuva com o mesmo rearranjo no começo da precipitação foram adimensionalisadas quanto ao percentual da precipitação acumulada no tempo para comparação.

Cabe frisar que o tempo de retorno não influencia nesta análise, tendo em vista que as precipitações mantém uma uniformidade adimensional do percentual de chuva acumulado no tempo em ambos os métodos.

Para exemplificar a adimensionalização das chuvas, é apresentada na Tabela 6 a chuva de projeto baseada na curva IDF do município de São Carlos, com duração de 120 minutos, precipitação total de 77,4 mm e tempo de retorno de 50 anos pelos métodos de Huff $1^{0}$ quartil e blocos alternados. Os totais precipitados expressos em milímetros e os percentuais acumulados da chuva de projeto de São Carlos são apresentados na Tabela 6 .

Tabela 6 - Chuva de projeto adimensional de São Carlos - SP

\begin{tabular}{|c|c|c|c|c|c|c|c|c|}
\hline \multirow[b]{2}{*}{$\begin{array}{l}\text { Percentual } \\
\text { do tempo } \\
(\%)\end{array}$} & \multicolumn{4}{|c|}{ HUFF $1^{\circ}$ quartil } & \multicolumn{4}{|c|}{ BLOCOS ALTERNADOS } \\
\hline & $\begin{array}{c}\text { Total } \\
\text { precipitado } \\
(\mathbf{m m})\end{array}$ & $\begin{array}{c}\text { Total } \\
\text { precipitado } \\
\text { acumulado } \\
\text { (mm) }\end{array}$ & $\begin{array}{c}\text { Percentual } \\
\text { precipitado } \\
(\%)\end{array}$ & $\begin{array}{c}\text { Percentual } \\
\text { precipitado } \\
\text { acumulado } \\
\text { (\%) }\end{array}$ & $\begin{array}{c}\text { Total } \\
\text { precipitado } \\
(\mathbf{m m})\end{array}$ & $\begin{array}{c}\text { Total } \\
\text { precipitado } \\
\text { acumulado } \\
(\mathbf{m m})\end{array}$ & $\begin{array}{c}\text { Percentual } \\
\text { precipitado } \\
\text { (\%) }\end{array}$ & $\begin{array}{c}\text { Percentual } \\
\text { precipitado } \\
\text { acumulado } \\
\text { (\%) }\end{array}$ \\
\hline 0 & 0 & 0 & 0 & 0 & 0 & 0 & 0 & 0 \\
\hline $10 \%$ & 39,5 & 39,5 & $44 \%$ & $44 \%$ & 1,9 & 1,9 & $2 \%$ & $2 \%$ \\
\hline $20 \%$ & 17,7 & 57,2 & $19 \%$ & $63 \%$ & 2,7 & 4,6 & $3 \%$ & $5 \%$ \\
\hline $30 \%$ & 10,0 & 67,2 & $11 \%$ & $74 \%$ & 4,2 & 8,8 & $5 \%$ & $10 \%$ \\
\hline $40 \%$ & 6,6 & 73,8 & $7 \%$ & $81 \%$ & 8,4 & 17,2 & $9 \%$ & $19 \%$ \\
\hline $50 \%$ & 4,7 & 78,5 & $5 \%$ & $86 \%$ & 29,8 & 47,0 & $33 \%$ & $52 \%$ \\
\hline $60 \%$ & 3,7 & 82,2 & $4 \%$ & $90 \%$ & 27,5 & 74,5 & $30 \%$ & $82 \%$ \\
\hline $70 \%$ & 2,8 & 85,0 & $3 \%$ & $93 \%$ & 8,1 & 82,6 & $9 \%$ & $91 \%$ \\
\hline $80 \%$ & 2,4 & 87,4 & $3 \%$ & $96 \%$ & 4,1 & 86,7 & $4 \%$ & $95 \%$ \\
\hline $90 \%$ & 2,0 & 89,4 & $2 \%$ & $98 \%$ & 2,6 & 89,3 & $3 \%$ & $98 \%$ \\
\hline $100 \%$ & 1,7 & 91,1 & $2 \%$ & $100 \%$ & 1,9 & 91,2 & $2 \%$ & $100 \%$ \\
\hline TOTAL & 91,1 & & $100 \%$ & & 91,2 & & $100 \%$ & \\
\hline
\end{tabular}


Para comparar os valores das chuvas adimensionais utilizados nesta pesquisa pelas obtidas por Huff (1967), procedeu-se a comparação das mesmas de acordo com a probabilidade de excedência nos respectivos quartis propostas pelo autor, como mostradona Figura 3. Assim, são apresentadas para análise as curvas de Huff $1^{\circ}$ quartil com $10 \%$ e $50 \%$ de probabilidade de excedência, a curva do $2^{\circ}$ quartil com $90 \%$ de probabilidade de excedência e a curva do $3^{\circ}$ quartil com $10 \%$ de probabilidade de excedência. As curvas apresentadas são as que melhor aproximam-se das utilizadas para as distribuições temporais de chuva de São Carlos aplicadas a esse trabalho e são apresentadas na Figura 20.

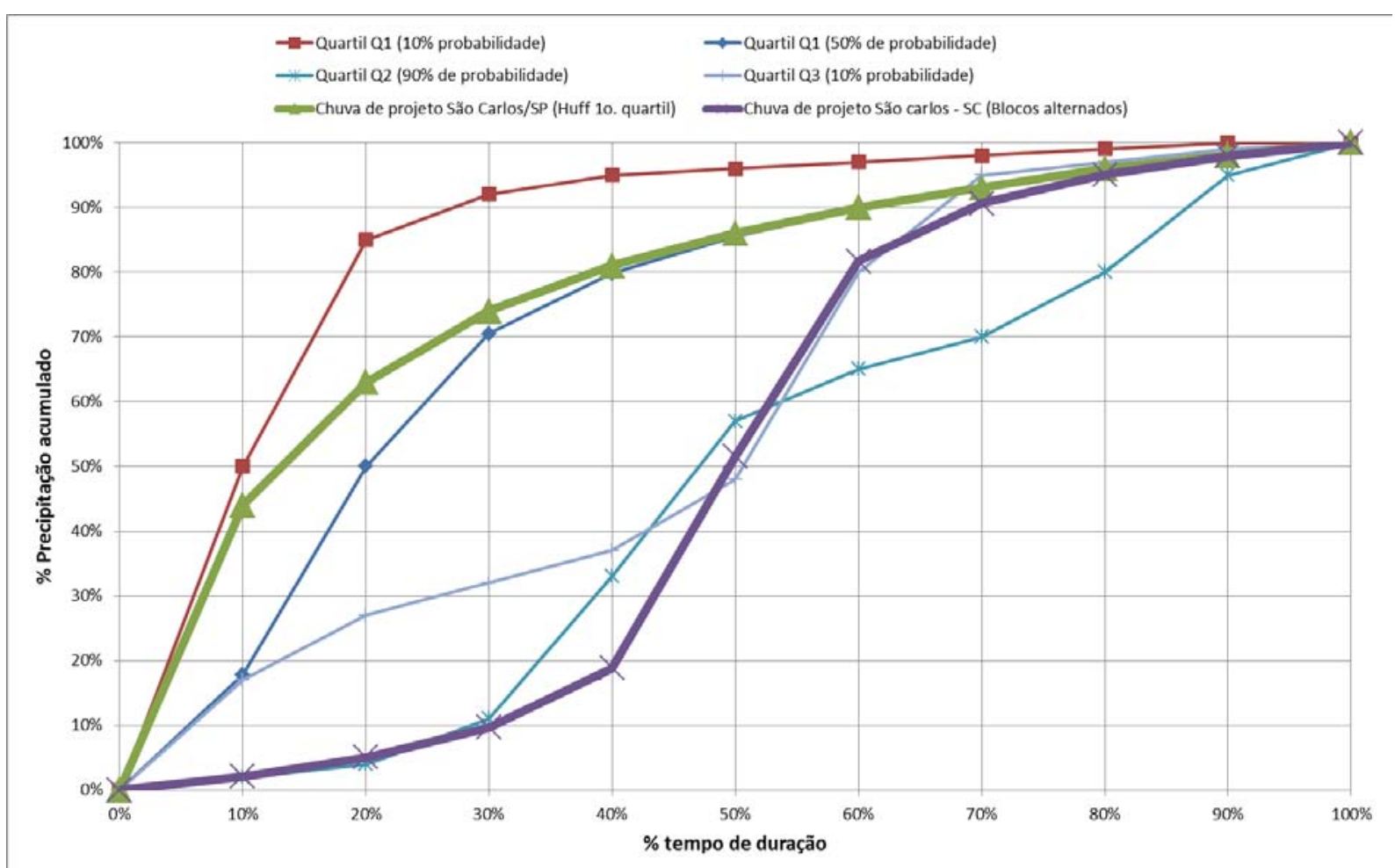

Figura 20 - Comparação entre o percentual acumulado de chuva em relação ao tempo entre a chuva de projeto de São Carlos/SP e a distribuição de Huff

Através da Figura 20 é possível perceber boa confrontação da chuva de projeto deste trabalho com máxima intensidade no início da duração com a proposta por Huff para o $1^{\circ}$ quartil entre $10 \%$ e 50\% de probabilidade de excedência com relação a proposta por Huff.

Para a chuva baseada no método dos blocos alternados, percebe-se que em até $30 \%$ do tempo de duração da chuva (eixo x), a curva se assemelha a verificada por Huff para o $2^{\circ}$ quartil com 90\% de probabilidade de excedência; e para o percentual de tempo de duração de $50 \%$ a $100 \%$ tem boa confrontação com a curva do $3^{\circ}$ quartil com $10 \%$ de probabilidade de excedência. 
Assim, pelo fato da chuva de projeto de São Carlos com pico de intensidade no começo da precipitação ter boa confrontação com a distribuição temporal de Huff no $1^{\circ}$ quartil, optou-se por utilizar esse método de distribuição de modo a comparar o mesmo modelo sob diferentes distribuições temporais: pico de intensidade de duração no início da precipitação (baseado no método de Huff $1^{\circ}$ quartil) e pico de intensidade na metade da duração da chuva (baseado no método dos blocos alternados).

\subsection{Medidas compensatórias consideradas na simulação hidrológica}

As medidas não estruturais deste estudo contemplaram a averbação de reserva legal nas áreas ainda não ocupadas da bacia hidrográfica, e um terço das áreas públicas como área verde.Com relação a averbação de reserva legal, foi considerada uma parcela de $20 \%$ do total da área ainda não ocupada da bacia, referente a parcela a ser preservada de acordo com o antigo código florestal brasileiro (BRASIL, 2001).

Com relação às áreas públicas, baseado no Plano Diretor do Município de São Carlos, são estabelecidos que: 18\% da área dos novos loteamentos devem corresponder a áreas públicas, das quais $10 \%$ devem ser destinadas ao uso institucional e $8 \%$ para áreas de lazer. Assim, propõe-se que um terço dessas áreas sejam ocupadas com vegetação (6\% das áreas dos novos loteamentos).

Já as medidas estruturais contemplam a implantação de cinco reservatórios de detenção in-line no Córrego do Gregório, de acordo com os projetos do Plano Diretor de Drenagem Urbana Ambientalmente Sustentável do Município de São Carlos. Os barramentos propostos localizam-se no Córrego do Sorregotti (1 reservatório), Córrego do Lazarini (2 reservatórios) e no Córrego do Gregório (2 reservatórios). A localização destes reservatórios e as curvas cota-volume e cota-área, utilizadas na modelação hidráulico-hidrológica das medidas estruturais podem ser encontradas em Anexo neste documento.

\subsection{Cenários e cálculo de $\mathrm{CN}$}

Para a realização da modelação hidrológica, foi utilizado o método SCS (Soil Conservation Service), desenvolvido pelo Departamento de Agricultura dos Estados Unidos. O método consiste na determinação da precipitação efetiva (precipitação que gera escoamento superficial) por meio do Curve Number (CN). O CN está associado: ao tipo de solo; às condições de uso e ocupação do solo; e à umidade antecedente, relacionada à precipitação 
acumulada dos últimos cinco dias (PORTO, 1995). Seu valor pode variar entre 0 e 100, de modo que quanto maior o número, maior o escoamento superficial em relação à precipitação total.A fórmula proposta pelo método e adaptada pelo USDA (1986):

$$
Q=\frac{(P-0,2 S)^{2}}{P+0,8 S}, P>0,2 S
$$

Onde:

$\mathrm{Q}=$ escoamento superficial direto em $\mathrm{mm}$

$\mathrm{P}=$ precipitação em $\mathrm{mm}$

$\mathrm{S}=$ retenção potencial do solo em mm

O valor da retenção potencial do solo "S" depende do tipo e da ocupação do solo e pode ser determinado facilmente por meio de tabelas próprias, ou ainda determinado in loco por meio de ensaios de infiltração. O método estabelece que $20 \%$ do total precipitado fica retido devidas à interceptação e retenção em depressões e este não é contabilizado nos cálculos de escoamento superficial, ou seja, o método somente será aplicado se o total precipitado superar este valor denominado perdas iniciais $\left(\mathrm{A}_{\mathrm{i}}\right)$. As variáveis do método SCS são apresentadas na Figura 21.

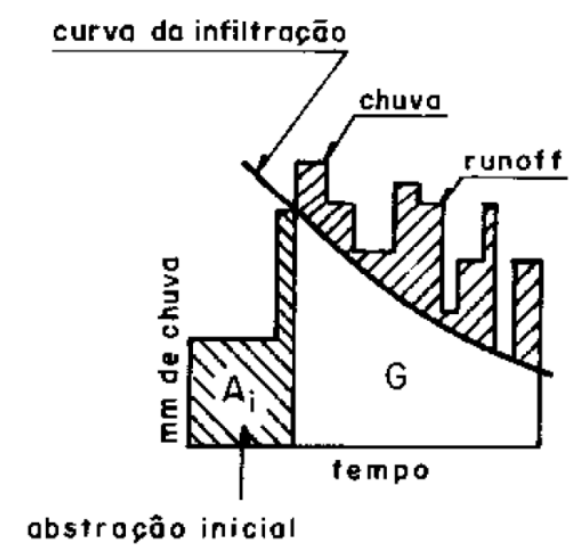

Figura 21 - Variáveis do método SCS Fonte: CHOW (1988)

Os dados foram obtidos com a utilização de imagens de satélite de alta resolução da área em estudo, com o apoio do software ArcGIS 9.3. Fazendo uso dessas informações, por meio de fotointerpretação, foi gerado um mapa de uso e ocupação do solo. Para cada categoria considerada no mapa, foi atribuído um valor do parâmetro CN (Curve Number), para estimar o escoamento superficial no exutório da bacia estudada. De acordo com Benini (2005) a bacia deve ser dividida em sub-bacias e a cada uma ser atribuído um valor de CN médio que considere os diferentes tipos de uso e ocupação do solo. 
A fim de modelar os impactos decorrentes da inundação, foram estabelecidos cenários de uso e ocupação do solo para o cenário atual e cenários para eventos futuros. Para equacionar as alterações potenciais do regime fluviométrico da bacia, decorrentes da implantação das medidas estruturais e não estruturais, foram propostos cenários a fim de comparar os impactos dessas medidas. Assim, foram estabelecidos 6tipos de cenários, baseados na pesquisa de Decina (2012).

\section{Cenário 1-atual}

São representadas as condições atuais de uso e ocupação do solo. Para isso, foram utilizadas estimativas de porcentagens da área impermeável diretamente conectada (AIDC), área impermeável não conectada (AINC) e área permeável (AP) para diversos tipos de uso do solo na cidade de São Carlos, a partir dos trabalhos de GAROTTI; IMOTO; BARBASSA (2007).

Com base nesses resultados, dividiu-se a área urbana da bacia em 11 áreas, as quais foram classificadas quanto a porcentagem de áreas permeáveis e impermeáveis existentes na bacia. Para as áreas permeáveis, foi adotado o valor de CN igual a 64 e para as áreas impermeáveis o valor de 98.

\section{Cenário 2 - Plano Diretor}

Neste cenário, considera-se que a ocupação futura da bacia do Córrego do Gregório foi estabelecida de acordo com as premissas do zoneamento das macrozonas rural e urbana previstas no Plano Diretor do Município de São Carlos. As macrozonas foram divididas em: Zonas 1 - Ocupação induzida; 2 - Ocupação condicionada; 3A e 3B - Recuperação e ocupação controlada; 5A e 5B - Proteção e ocupação restrita; 6 - Produção agrícola familiar. A configuração de uso e ocupação do solo em cada macrozona prevista no plano diretor do município é apresentada na Figura 22. 


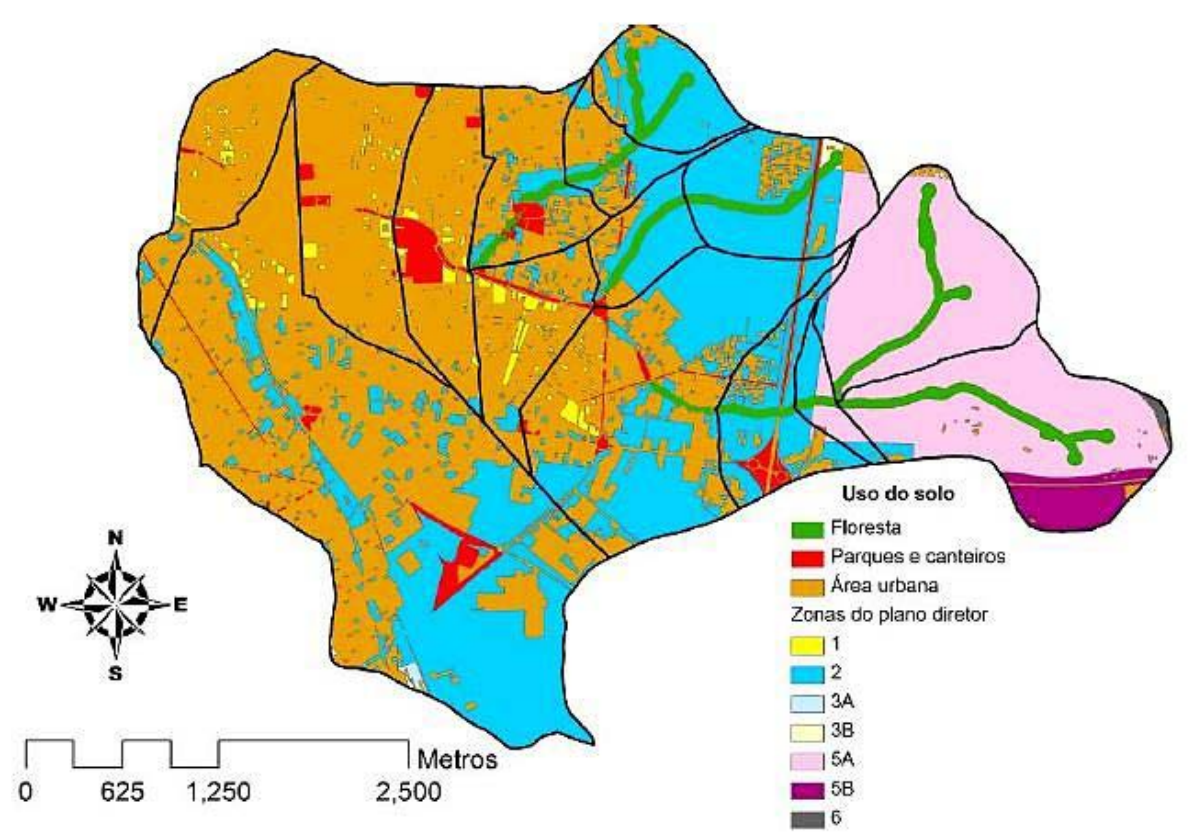

Figura 22- Uso e ocupação do solo nas macrozonas descritas no plano diretor Fonte: DECINA (2012)

\section{Cenário 3 - Plano Diretor e medidas estruturais}

Neste cenário de ocupação futura, além da aplicação das diretrizes de zoneamento do plano diretor do município, são inseridos os reservatórios de detenção propostos no plano diretor de drenagem urbana do município. Assim, este cenário possui a mesma configuração de uso e ocupação do solo do cenário 2 com a adição dos cinco reservatório previstos no plano.

\section{Cenário 4-Plano Diretor e medidas não estruturais}

Neste cenário, são aplicadas as medidas não estruturais descritas no item 4.3 medidas compensatórias - para as regiões ainda não urbanizadas da bacia do Córrego do Gregório. Neste cenário, os valores de $\mathrm{CN}$ e as porcentagens referentes a áreas cobertas com vegetação são diferentes nas macrozonas.

\section{Cenário 5 - Plano diretor, medidas estruturais e medidas não estruturais}

No cenário 5, considera-se as características de uso e ocupação do solo do cenário 4 acrescidas das medidas estruturais do cenário 3 (reservatórios de detenção). Assim, neste cenário pode-se verificar os impactos decorrentes da aplicação combinada de medidas estruturais e não estruturais. 


\section{Cenário 6 - Sem plano diretor}

O objetivo deste cenário foi representar uma forma de ocupação da bacia do Córrego do Gregório em que não houve ação do poder público com o objetivo de regular o uso e ocupação do solo nos loteamentos. Neste cenário, foi aplicado o padrão de urbanização atual da bacia do Gregório para as áreas ainda não ocupadas, ou seja, considera-se uma ocupação em que o poder público não seja capaz de regular adequadamente a ocupação das áreas não urbanizadas.

\subsubsection{CN médios das sub-bacias}

A partir do mapeamento descritivo do uso e ocupação do solo para cada cenário e para a delimitação de cada sub-bacia, foram calculados seus respectivos CN (condição II). Os resultados são apresentados na Tabela 7.

Tabela 7 - Valores de CN médio para cada sub-bacia nos respectivos cenários

\begin{tabular}{|c|c|c|c|c|c|c|}
\hline \multirow{2}{*}{ Sub-bacias } & \multicolumn{6}{|c|}{ Cenários } \\
\hline & 1 & 2 & 3 & 4 & 5 & 6 \\
\hline 1 & 66,51 & 77,73 & 77,73 & 72,88 & 72,88 & 91,46 \\
\hline 2 & 62,99 & 77,26 & 77,26 & 73,38 & 73,38 & 90,92 \\
\hline 3 & 68,97 & 88,68 & 88,68 & 82,60 & 82,6 & 91,38 \\
\hline 4 & 72,95 & 83,67 & 83,67 & 82,98 & 82,98 & 89,41 \\
\hline 5 & 65,55 & 84,09 & 84,09 & 77,71 & 77,71 & 91,12 \\
\hline 6 & 78,97 & 90,79 & 90,79 & 85,62 & 85,62 & 92,08 \\
\hline 7 & 78,98 & 93,29 & 93,29 & 88,70 & 88,70 & 94,16 \\
\hline 8 & 66,55 & 88,53 & 88,53 & 82,34 & 82,34 & 89,59 \\
\hline 9 & 80,17 & 90,93 & 90,93 & 87,38 & 87,38 & 91,54 \\
\hline 10 & 87,39 & 91,75 & 91,75 & 91,79 & 91,79 & 92,01 \\
\hline 11 & 90,50 & 94,34 & 94,34 & 93,56 & 93,56 & 94,61 \\
\hline 12 & 91,24 & 92,80 & 92,80 & 92,61 & 92,61 & 92,90 \\
\hline 13 & 93,11 & 94,50 & 94,50 & 94,43 & 94,43 & 94,57 \\
\hline 14 & 85,11 & 93,67 & 93,67 & 90,66 & 90,66 & 94,20 \\
\hline 15 & 93,32 & 94,95 & 94,95 & 94,73 & 94,73 & 95,04 \\
\hline
\end{tabular}

Fonte: Adaptado de DECINA (2012)

\subsection{Cadastro dos imóveis}

Para delimitar a área de abrangência deste cadastro, foi utilizado como referência a mancha de inundação obtida a partir da modelagem com o software HecGeoRas 4.3 referente a um evento de precipitação com tempo de retorno de 100 anos, para o cenário 6 (sem plano diretor), cenário com maior área de abrangência. Nele, todas as zonas do plano diretor foram ocupadas da mesma forma. Este cenário foi atribuído como fator limitante do máximo prejuízo estimado para a região. 
Os imóveis foram cadastrados com o uso de ferramentas de sistemas de informações geográficas (SIG). Para iniciar o cadastro dos imóveis, foi utilizado um mapa com informações sobre logradouros municipais obtidos no "SIGA SC - Sistemas de Informações Geográficas de São Carlos”, o qual se encontra no portal da prefeitura de São Carlos, de livre acesso através da internet. Por meio do portal, foi possível discriminar os logradouros presentes na área em estudo, a partir de sobreposição deste mapa ao mapa da mancha de inundação do cenário 6. O mapa dos logradouros obtidos no portal do SIGA SC é apresentado na Figura 23 e a área da mancha inundação na Figura 24.

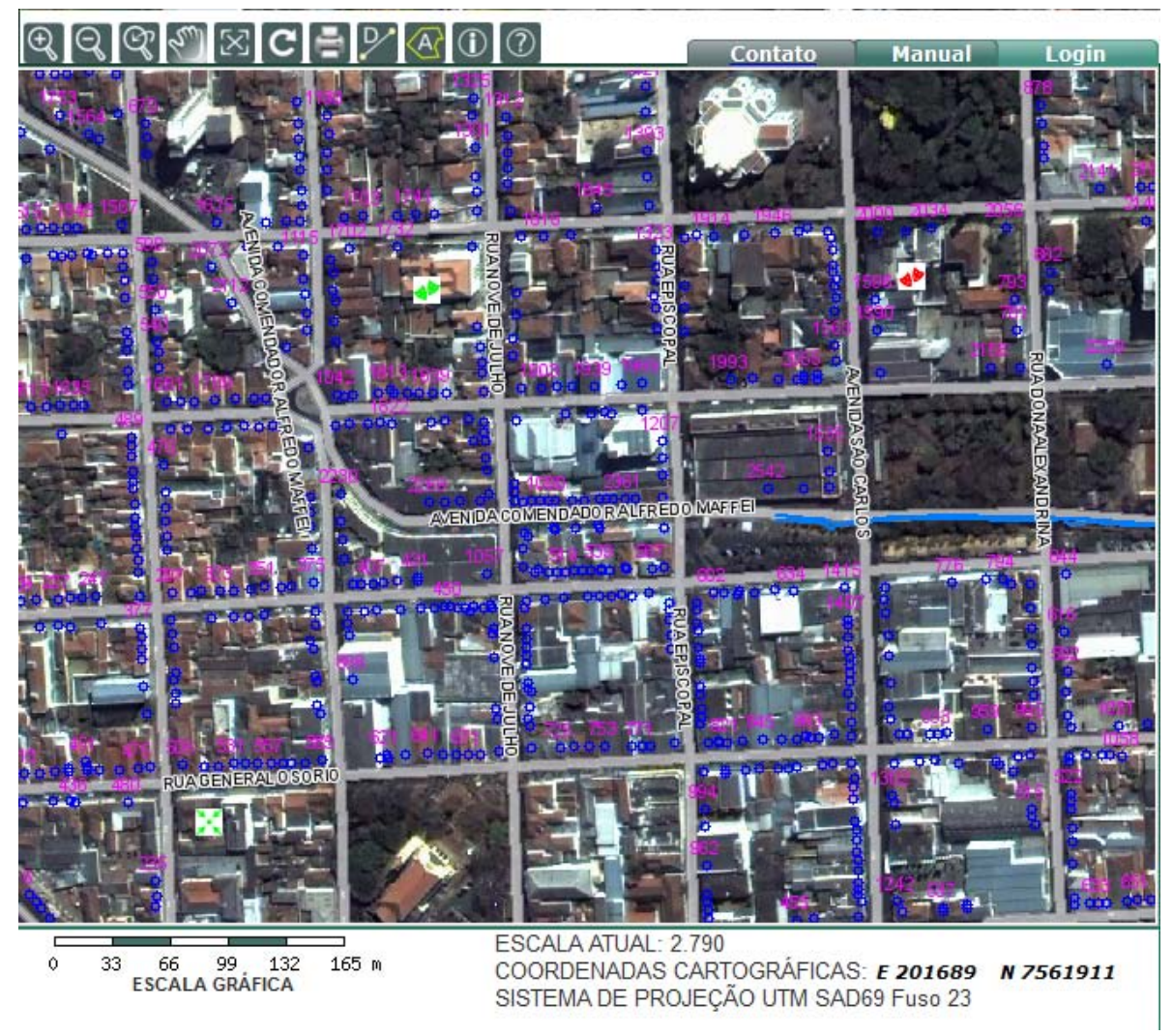

Figura 23 - Mapa de logradouros do município de São Carlos - SP Fonte: Sistema de Informações Geográfica de São Carlos - SIGA SC 


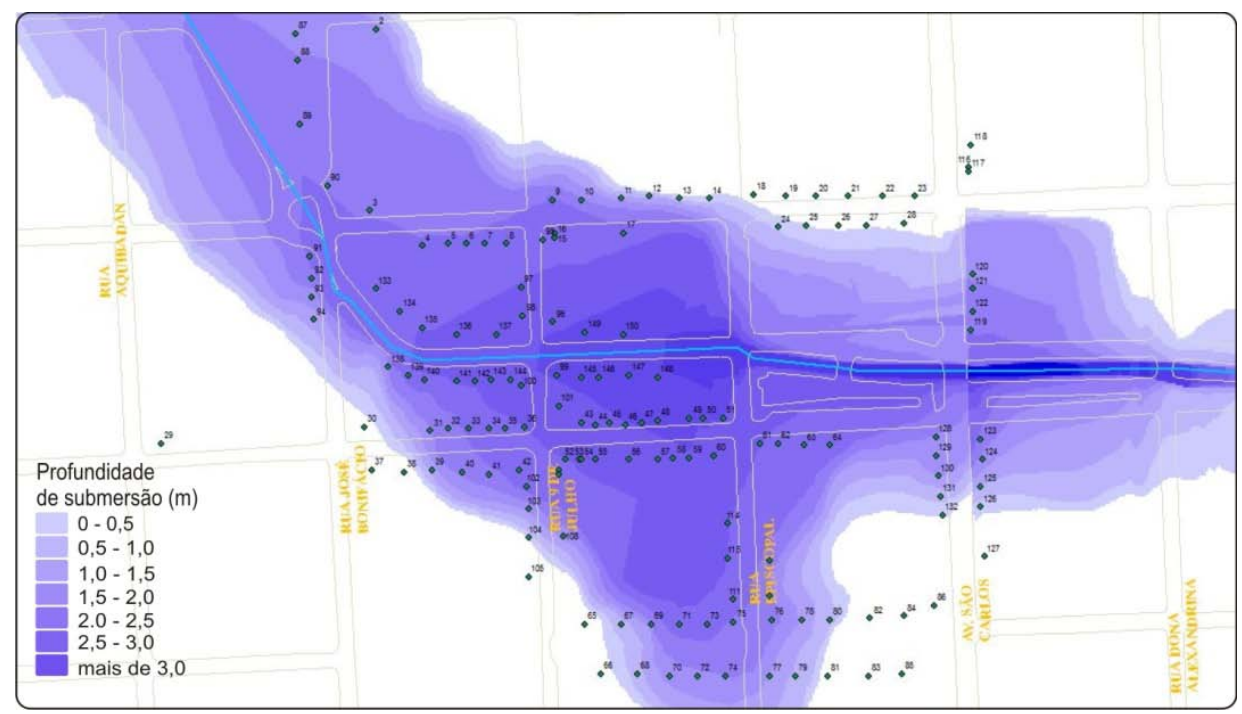

Figura 24 - Mancha de inundação com tempo de retorno de 100 anos no cenário 6 - sem plano diretor

Através da delimitação da área de abrangência da mancha de inundação, foram obtidas as informações para duas categorias de imóveis: residenciais e comerciais.

\subsubsection{Comércio}

Os dados cadastrais das empresas foram obtidos na Associação Comercial e Industrial de São Carlos (ACISC), o qual disponibiliza, sob o pagamento de taxa, informações sobre a razão social e endereço das empresas cadastradas na associação. Com essas informações e as obtidas no SIGA SC sobre logradouros municipais, foi possível delimitar as empresas contidas na mancha de inundações e realizar o cadastramento.

Por meio do mapeamento, foi cadastrado um total de 121 empresas contidas na mancha de inundação com maior área de abrangência (Cenário 6 com TR=100 anos).

\subsubsection{Caracterização dos imóveis comerciais}

Os imóveis comerciais foram caracterizados de acordo com a área construída e o tipo de atividade comercial. Para mensurar a área construída foi utilizado o software Google Earth Pro versão 7, versão que possibilita o cálculo de área através de vetorização manual de polígonos.A resolução obtida foi suficiente para distinguir os telhados e fornecer a área de cada imóvel. Em relação ao tipo de atividade, utilizou-se o Google Street View com imagens da cidade de São Carlos do ano de 2011, e caracterizou-se a atividade por observação das fachadas comerciais. 
Para estimar os prejuízos decorrentes de eventos de inundação, foram utilizadas as curvas de danos por profundidade de submersão elaborada por Milograna (2009), que elaborou curvas para diversas categorias de atividade de estabelecimentos comerciais, relacionando o prejuízo do imóvel com sua respectiva área. Tal relação parte da hipótese de que, em lojas de varejo, a área útil do imóvel é utilizada plenamente para o armazenamento de produtos em estoque. Assim, quanto maior a área, maior o potencial de estoque de produtos e, portanto, maiores serão as perdas decorrentes de eventos de inundação.

Desta forma, foram levantadas as áreas de todos os imóveis presentes na mancha de inundação a fim de estimar os danos ao estoque por profundidade de submersão. Foi aplicado um fator de redução de $25 \%$ da área do imóvel com relação a obtida através da vetorização manual da área de telhado com o intuito de subtrair as áreas administrativas e sanitários presentes no local. A porcentagem foi baseada em levantamentos de imobiliárias com descrição da área e tipos de cômodos de imóveis para atribuir um valor médio de área passível de estoque.

As empresas foram divididas de acordo com a atividade comercial proposta por Milograna (2009), com o intuito de aplicar as curvas de danos por profundidade de submersão (DPS) obtida pela autora. Dessa forma, foram classificas e utilizadas as equações para sete tipos de atividade, como descrito no Quadro 3. No quadro, a variável “ $x$ ” refere-se a profundidade de submersão da empresa contida na mancha de inundação em metros (m), sendo x considerado apenas para alturas acima de 0,35 m (altura da sarjeta); já a variável “y” quantifica o prejuízo individual da empresa em relação a altura que a água atingiu o imóvel, expressa em Reais (R\$).

Quadro 3 - Classificação do tipo de atividade e equação utilizada para calcular os danos por profunidade de submersão das empresas contidas na mancha de inundação

\begin{tabular}{|c|c|}
\hline Tipo de atividade & Equação \\
\hline $\begin{array}{c}\text { Lojas de departamento, artigos de armarinho, vestuário e } \\
\text { tecidos, sapatarias e produtos de couro }\end{array}$ & $\mathrm{y}=305,919+247,666 * \ln (\mathrm{x})$ \\
\hline Mercados e lojas de departamento & $\mathrm{y}=238,37+167,267 * \ln (\mathrm{x})$ \\
\hline Móveis, eletrodomésticos, equipamentos de informática & $\mathrm{y}=357,015+464,437 * \ln (\mathrm{x})$ \\
\hline Produtos farmacêuticos, perfumaria e cosméticos & $\mathrm{y}=319,796+286,196 * \ln (\mathrm{x})$ \\
\hline Joalherias, relojoarias e óticas & $\mathrm{y}=327,096+361,147 * \ln (\mathrm{x})$ \\
\hline Restaurantes, lanchonetes, bares e cafés & $\mathrm{y}=62,979+66,847 * \ln (\mathrm{x})$ \\
\hline Escritórios de serviços e consultoria & $\mathrm{y}=96,339+21,628 * \ln (\mathrm{x})$ \\
\hline
\end{tabular}

Fonte: Milograna (2009) 


\subsubsection{Residencial}

Para as residências, foram utilizados microdados agregados por setor censitário das regiões delimitadas geograficamente pelo censo do IBGE (2011). Esses microdados, descritos na revisão bibliográfica deste trabalho (item 3.9.1.4), foram utilizados para traçar o perfil socioeconômico das famílias residentes nos imóveis da mancha de inundação.

O cadastro das residências também foi realizado através de observações pelo Google Street View para se criar um cadastro dos imóveis residenciais. Dessa forma, cadastrou-se 30 residências presentes na mancha de inundação da maior área de abrangência.

\subsubsection{Caracterização das residências}

Foram mapeados os setores próximos à mancha de inundação e extraídos do arquivo que contém a base de informações por setores censitários do IBGE. A descrição da delimitação do perímetro do setor censitário pelo IBGE é elaborada com base em um percurso, em que se estabelece o caminho a ser percorrido para delimitar o perímetro do setor, de acordo com as esquinas dos logradouros a serem percorridos, com início e fim estabelecidos (arquivo Descrição_SP_Exceto_Capital.xls).

Foram selecionados dois setores, os quais se encontram descritos no Quadro 4. O mapa com os setores censitários é apresentado na Figura 25.

Quadro 4 - Descrição dos setores censitários contidos na mancha de inundação da área central de São Carlos

\begin{tabular}{|c|c|c|}
\hline Geocódigo & Posição inicial & \multicolumn{1}{c|}{ Perímetro } \\
\hline 354890605000014 & $\begin{array}{c}\text { Rua Treze de } \\
\text { Maio com Rua } \\
\text { Nove de Julho. }\end{array}$ & $\begin{array}{l}\text { Do ponto inicial segue Rua Treze de Maio - Rua São Joaquim - Rua } \\
\text { Jesuíno de Arruda - Rua Dona Alexandrina - Rua Geminiano Costa - } \\
\text { Rua Nove de Julho - por esta até o ponto inicial. }\end{array}$ \\
\hline 354890605000015 & $\begin{array}{c}\text { Rua Conde do } \\
\text { Pinhal com Rua } \\
\text { José Bonifácio }\end{array}$ & $\begin{array}{c}\text { Do ponto inicial Rua Conde do Pinhal - Rua Nove de Julho - Rua } \\
\text { Geminiano Costa - Rua Dona Alexandrina - Rua General Osório - Rua } \\
\text { José Bonifácio - por esta até o ponto inicial. }\end{array}$ \\
\hline
\end{tabular}

Fonte: Adaptado de IBGE (2011) 


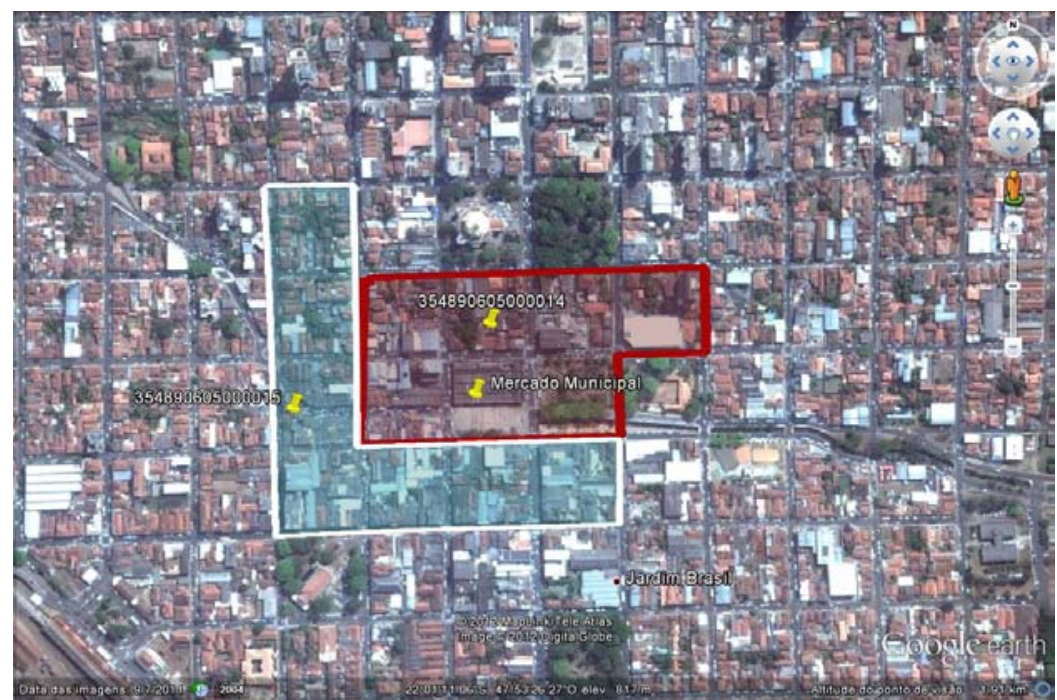

Figura 25- Delimitação das áreas por setores censitários objeto do estudo

Após a delimitação do percurso, procedeu-se a obtenção das variáveis investigadas pelo IBGE para os setores. Para isso, utilizaram-se as planilhas com informações básicas, sobre pessoas, domicílios e renda. As variáveis extraídas das planilhas de interesse com informações socioeconômicas das pessoas e dos domicílios contidas nos setores censitários são apresentadas nas Tabelas 8 e 9.

Tabela 8 - Caracterização dos moradores presentes nos setores censitários

\begin{tabular}{c|c|c|c|c|c}
\hline Geocódigo & $\begin{array}{c}\text { Domicílios } \\
\text { Particulares } \\
\text { Permanentes } \\
\text { (DPP) }\end{array}$ & $\begin{array}{c}\text { Moradores } \\
\text { em DPP }\end{array}$ & $\begin{array}{c}\text { Média do número } \\
\text { de moradores em } \\
\text { DPP }\end{array}$ & $\begin{array}{c}\text { Variância do } \\
\text { número de } \\
\text { moradores em } \\
\text { DPP }\end{array}$ & $\begin{array}{c}\text { Valor do rendimento } \\
\text { nominal médio mensal } \\
\text { dos responsáveis por } \\
\text { DPP (R\$) }\end{array}$ \\
\hline 354890605000014 & 60 & 119 & 1,98 & 1,07 & $2.801,40$ \\
\hline 354890605000015 & 46 & 118 & 2,57 & 1,85 & $2.637,33$ \\
\hline TOTAIS & $\mathbf{1 0 6}$ & $\mathbf{2 3 7}$ & $\mathbf{2 , 2 8}$ & $\mathbf{1 , 4 6}$ & $\mathbf{2 . 7 1 9 , 3 7}$ \\
\hline \multicolumn{7}{c}{ Fonte: Adaptado de IBGE (2011) }
\end{tabular}

Tabela 9 - Caracterização dos domicílios contidos na mancha de inundação

\begin{tabular}{c|c|c|c|c|c|c}
\hline Geocódigo & $\begin{array}{c}\text { Domicílios } \\
\text { tipo casa }\end{array}$ & $\begin{array}{c}\text { Domicílios tipo } \\
\text { apartamento }\end{array}$ & $\begin{array}{c}\text { Domicílios } \\
\text { próprios ou } \\
\text { quitados }\end{array}$ & $\begin{array}{c}\text { Domicílios } \\
\text { com 1 } \\
\text { morador }\end{array}$ & $\begin{array}{c}\text { Domicílios } \\
\text { com 2 } \\
\text { moradores }\end{array}$ & $\begin{array}{c}\text { Domicílios } \\
\text { com } 3 \text { ou } \\
\text { mais } \\
\text { moradores }\end{array}$ \\
\hline 354890605000014 & 8 & 52 & 21 & 23 & 22 & 10 \\
\hline 354890605000015 & 41 & 5 & 23 & 13 & 10 & 12 \\
\hline TOTAL & $\mathbf{4 9}$ & $\mathbf{5 7}$ & $\mathbf{4 4}$ & $\mathbf{3 6}$ & $\mathbf{3 2}$ & $\mathbf{2 2}$ \\
\hline
\end{tabular}

Fonte: Adaptado de IBGE (2011)

Pelas Tabelas 8 e 9, verifica-se a existência de apenas 8 domicílios do tipo casa no geocódigo com final "14" e 41 domicílios tipo casa no geocódigo com final “15”. Após a verificação da localização destes imóveis, foi possível verificar que as residenciais contidas na mancha de inundação localizam-se exclusivamente no setor de geocódigo com final “15”. 
Dessa forma, ignoraram-se os imóveis do geocódigo com final 14 devido à inexistência de imóvel tipo casa na mancha de inundação.

Dentre os microdados agregados por setores censitários do IBGE (2010), cabe destaque neste estudo os dados para o geocódigo com final 15 referentes aos valores de rendimento nominal mensal domiciliar desagregados dos domicílios pesquisados. Os dados são apresentados na Tabela 10.

Tabela 10 - Dados desagregados de rendimento mensal domiciliar

\begin{tabular}{c|c|c|c|c|c|c}
\hline $\begin{array}{c}\text { Geocódigo } \\
\text { 354890605000015 }\end{array}$ & \multicolumn{6}{|c}{$\begin{array}{c}\text { Domicílios particulares com rendimento mensal domiciliar } \\
\text { (salários mínimos) }\end{array}$} \\
\cline { 2 - 7 } & $\mathbf{1 / 2}$ a $\mathbf{1}$ & $\mathbf{1}$ a 2 & $\mathbf{2}$ a 3 & $\mathbf{3}$ a $\mathbf{5}$ & $\mathbf{5}$ a $\mathbf{1 0}$ & mais de $\mathbf{1 0}$ \\
\hline Número de domicílios & 8 & 13 & 7 & 7 & 5 & 1 \\
\hline Salário mínimo de 2009 (R\$) & 540 & 1080 & 1620 & 2700 & 5400 & 5400 \\
\hline \multicolumn{7}{|c|}{ Fonte: IBGE (2011) }
\end{tabular}

Os valores de rendimento nominal mensal domiciliar das residências serviram de base para definir a classe econômica de cada residência. Esta base teve como referência os dados da Associação Brasileira de Pesquisas Populacionais - ABEP (2009), que define as classes econômicas brasileiras de acordo com a Tabela 11.

Tabela 11 - Classificação das residências brasileiras quanto à classe econômica

\begin{tabular}{c|c|c|c|c|c|c|c|c}
\hline \multicolumn{10}{c}{ Classificação econômica das residências brasileiras } \\
\hline Classe Econômica & A1 & A2 & B1 & B2 & C1 & C2 & D & E \\
\hline $\begin{array}{c}\text { Rendimento nominal } \\
\text { mensal (R\$) }\end{array}$ & $11.480,00$ & $8.295,00$ & $4.754,00$ & $2.656,00$ & $1.459,00$ & 962,00 & 680,00 & 415,00 \\
\hline
\end{tabular}

Fonte: Adaptado de ABEP (2009)

A partir da classificação econômica de cada domicílio, foi possível caracterizar os padrões de conteúdo dos imóveis. Essa caracterização foi baseada nas pesquisas de Machado (2005) e Cançado (2009). Os dados apresentados na Tabela 12 mostram os padrões de conteúdo de cada cômodo de acordo com a classe social em que a residência está inserida. 
Tabela 12 - Relação da quantidade de bens de uma residência de acordo com sua classe social

\begin{tabular}{|c|c|c|c|c|c|c|c|}
\hline \multirow{2}{*}{$\begin{array}{l}\text { CôMODO } \\
\text { Quarto de casal }\end{array}$} & \multicolumn{5}{|c|}{ QUANTIDADE DE BENS / CLASSE } & \multirow{2}{*}{ Valor } & \multirow{2}{*}{$\begin{array}{l}\text { Faixa de } \\
\text { inundação }\end{array}$} \\
\hline & $\mathbf{A}$ & $\mathbf{B}$ & $\mathbf{C}$ & D & $\mathbf{E}$ & & \\
\hline Cama de casal & 1 & 1 & 1 & 1 & 1 & 500,00 & 0,50 а 0,75 \\
\hline Guarda-roupa & 1 & 1 & 1 & 1 & 1 & 600,00 & 0,75 a 1,00 \\
\hline Cômoda & 1 & 1 & 0 & 0 & 0 & 370,00 & 0,50 a 0,75 \\
\hline Criado & 1 & 1 & 1 & 0 & 0 & 150,00 & 0,50 a 0,75 \\
\hline Escrivaninha & 1 & 0 & 0 & 0 & 0 & 250,00 & 0,50 a 0,75 \\
\hline TV & 1 & 1 & 0 & 0 & 0 & $1.500,00$ & 1,00 a 1,50 \\
\hline Blue-ray & 1 & 0 & 0 & 0 & 0 & 500,00 & 1,00 a 1,50 \\
\hline Micro-system & 1 & 0 & 0 & 0 & 0 & 300,00 & 1,00 a 1,50 \\
\hline Telefone s/ fio & 1 & 1 & 0 & 0 & 0 & 120,00 & 1,00 a 1,50 \\
\hline Ar Condicionado & 1 & 0 & 0 & 0 & 0 & $1.200,00$ & 0,75 a 1,00 \\
\hline Ventilador & 0 & 1 & 1 & 0 & 0 & 90,00 & 1,00 a 1,50 \\
\hline TOTAL & $5.490,00$ & $3.330,00$ & $1.340,00$ & $1.100,00$ & $1.100,00$ & & \\
\hline Quarto de solteiro & A & B & C & D & $\mathbf{E}$ & & \\
\hline Cama de solteiro & 1 & 1 & 1 & 1 & 1 & 310,00 & 0,50 a 0,75 \\
\hline Guarda-roupa & 1 & 1 & 1 & 1 & 1 & 600,00 & 0,75 a 1,00 \\
\hline Cômoda & 1 & 0 & 0 & 0 & 0 & 370,00 & 0,50 a 0,75 \\
\hline criado & 1 & 0 & 0 & 0 & 0 & 150,00 & 0,50 а 0,75 \\
\hline Escrivaninha & 1 & 1 & 0 & 0 & 0 & 250,00 & 0,50 a 0,75 \\
\hline TV & 1 & 0 & 0 & 0 & 0 & $1.500,00$ & 1,00 a 1,50 \\
\hline Micro-system & 1 & 0 & 0 & 0 & 0 & 300,00 & 1,00 a 1,50 \\
\hline Ventilador & 1 & 1 & 0 & 0 & 0 & 90,00 & 1,00 a 1,50 \\
\hline TOTAL & $3.570,00$ & $1.250,00$ & 910,00 & 910,00 & 910,00 & & \\
\hline Sala & A & B & C & D & E & & \\
\hline$\overline{\text { Estante }}$ & 1 & 1 & 1 & 1 & 1 & 700,00 & 0,50 а 0,75 \\
\hline Sofá & 1 & 1 & 1 & 1 & 0 & 750,00 & 0,50 a 0,75 \\
\hline $\mathrm{TV}$ & 1 & 1 & 1 & 0 & 0 & $1.500,00$ & 1,00 a 1,50 \\
\hline Blue-ray & 1 & 1 & 1 & 0 & 0 & 500,00 & 1,00 a 1,50 \\
\hline telefones/fio & 1 & 1 & 1 & 1 & 0 & 120,00 & 1,00 a 1,50 \\
\hline Micro system & 1 & 1 & 1 & 0 & 0 & 300,00 & 1,00 a 1,50 \\
\hline Mesa-cadeiras & 0 & 0 & 0 & 0 & 1 & 800,00 & 0,50 a 0,75 \\
\hline TOTAL & $3.870,00$ & $3.870,00$ & $3.870,00$ & $1.570,00$ & $1.500,00$ & & \\
\hline Cozinha & A & B & C & D & $\mathbf{E}$ & & \\
\hline Estante & 1 & 1 & 1 & 0 & 0 & 900,00 & 0,50 а 0,75 \\
\hline Fogão & 1 & 1 & 1 & 1 & 1 & 750,00 & 1,00 a 1,50 \\
\hline Exaustor & 1 & 1 & 0 & 0 & 0 & 500,00 & 2,00 a 3,50 \\
\hline Forno elétrico & 1 & 0 & 0 & 0 & 0 & 550,00 & 1,00 a 1,50 \\
\hline Microondas & 1 & 1 & 0 & 0 & 0 & 400,00 & 1,00 a 1,50 \\
\hline Geladeira & 1 & 1 & 1 & 1 & 1 & $1.000,00$ & 0,50 a 0,75 \\
\hline freezer & 1 & 0 & 0 & 0 & 0 & $1.500,00$ & 0,50 a 0,75 \\
\hline Processador de alimentos & 1 & 1 & 0 & 0 & 0 & 300,00 & 1,00 a 1,50 \\
\hline Lavador de louças & 1 & 1 & 0 & 0 & 0 & 500,00 & 0,50 a 0,75 \\
\hline TOTAL & $6.400,00$ & $4.350,00$ & $2.650,00$ & $1.750,00$ & $1.750,00$ & & \\
\hline Escritório/biblioteca & A & B & $\mathrm{C}$ & D & $\mathbf{E}$ & & \\
\hline Estante & 1 & 1 & 1 & 1 & 1 & 700,00 & 0,50 a 0,75 \\
\hline Mesa-cadeiras & 1 & 1 & 1 & 1 & 1 & 800,00 & 0,50 a 0,75 \\
\hline telefone s/ fio & 1 & 1 & 0 & 0 & 0 & 120,00 & 1,00 a 1,50 \\
\hline Microcomputador & 1 & 1 & 1 & 0 & 0 & $1.800,00$ & 1,00 a 1,50 \\
\hline TOTAL & $3.420,00$ & $3.420,00$ & $3.300,00$ & $1.500,00$ & $1.500,00$ & & \\
\hline Sala adicional & A & B & C & D & $\mathbf{E}$ & & \\
\hline Estante & 1 & 1 & 1 & 1 & 1 & 700,00 & 0,50 а 0,75 \\
\hline Sofá & 1 & 1 & 1 & 1 & 1 & 750,00 & 0,50 a 0,75 \\
\hline TOTAL & $1.450,00$ & $1.450,00$ & $1.450,00$ & $1.450,00$ & $1.450,00$ & & \\
\hline Área de serviço & $\mathrm{A}$ & $\mathrm{B}$ & $\mathrm{C}$ & $\mathrm{D}$ & $\mathrm{E}$ & & \\
\hline aspirador de pó & 1 & 1 & 0 & 0 & 0 & 200,00 & 1,50 а 2,00 \\
\hline Máquina de lavar roupas & 1 & 1 & 1 & 0 & 0 & 900,00 & 0,50 a 0,75 \\
\hline Secadora de roupas & 1 & 0 & 0 & 0 & 0 & 600,00 & 2,00 a 3,50 \\
\hline 'Tanquinho & 0 & 0 & 0 & 1 & 0 & 200,00 & 0,50 a 0,75 \\
\hline TOTAL & $1.700,00$ & $1.100,00$ & 900,00 & 200,00 & - & & \\
\hline TOTAL POR RESIDÊNCIA & $25.900,00$ & $18.770,00$ & $14.420,00$ & $8.480,00$ & $8.210,00$ & & \\
\hline DEPRECIAÇÃO (50\%) & $12.950,00$ & $9.385,00$ & $7.210,00$ & $4.240,00$ & $4.105,00$ & & \\
\hline
\end{tabular}

Fonte: Adaptado de Cançado (2009) e Machado (2005)

Os valores de cada bem móvel descrito na Tabela 12 foram obtidos por meio de pesquisa na internet em lojas especializadas e através de folhetos promocionais obtidos junto 
a lojas de São Carlos/SP. Foi aplicado taxa de depreciação de $50 \%$ em relação ao valor de bens novos, taxa também utilizada por Cançado (2009).

A coluna “faixa de inundação” (Tabela 12) sugere margens de altura de submersão das residências em que o bem citado sofre perda, ou seja, a altura a partir da qual o bem sofre danos pelo contato com a água decorrentes das inundações. Pela Tabela 12, pode-se concluir que uma residência classe A, ou seja, com maior poder aquisitivo, é susceptível a um prejuízo máximo ao conteúdo de $\mathrm{R} \$ 12.950,00$, enquanto que uma residência classe $\mathrm{C}$ tem prejuízo máximo de R\$ 7.210,00.

A profundidade de submersão para cada agente do sistema (residenciais e comerciais) foi obtida através do HecGeoRas (suplemento do software ArcGis 9.3) a partir das coordenadas geográficas de cada imóvel. As informações foram exportadas do ArcGis 9.3 para o Microsoft Excel através da ferramenta Spacial Analist, suplemento do ArcGis. Assim, foram geradas planilhas para cada evento com a identificação de cada empresa e a respectiva profundidade de submersão em que se encontra. A altura de submersão serviu de base para o cálculo dos prejuízos dos imóveis.

\subsection{Obtenção das coordenadas}

A partir da localização dos imóveis obtidas pelo “Google Street View”, importou-se os dados cadastrados (imóveis comerciais e residenciais) para a plataforma do ArcGis 9.3. Foram atribuídas coordenadas UTM Datum Córrego Alegre $23^{\circ} \mathrm{S}$ em uma tabela para cada empresa e residência, sendo que para cada imóvel foi atribuído um número de identificação (ID) e sua respectiva coordenada utilizadas na importação para o ArcGis 9.3 (Anexo A e B).O mapa com os imóveis cadastrados é apresentado na Figura 26. 


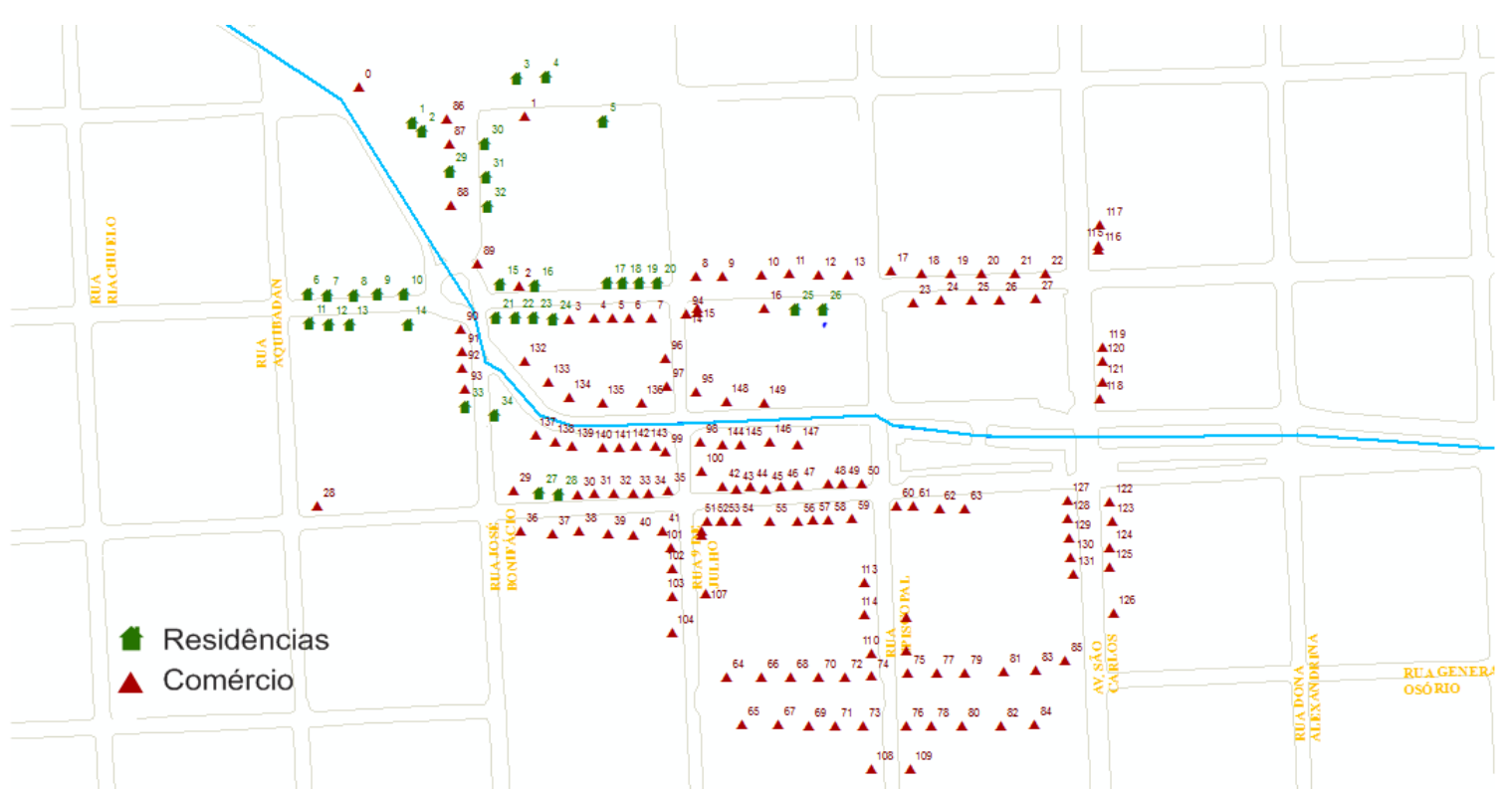

Figura 26 - Mapa com os imóveis residenciais e comerciais cadastrados.

\section{7. Índice de ameaça da inundação ao conteúdo dos domicílios}

A estimativa da perda porcentual do conteúdo foi baseada na Figura 27 elaborada por Cançado (2009), que relaciona a suscetibilidade média de perda do conteúdo do imóvel com a altura da inundação, criando um índice de perda para cada altura de submersão. Este índice foi denominado pela autora como Índice de ameaça da inundação ao conteúdo dos domicílios $I A_{M 2}$. O índice de susceptibilidade de danos ao conteúdo elaborado por Cançado (2009) é apresentado na Figura 27.

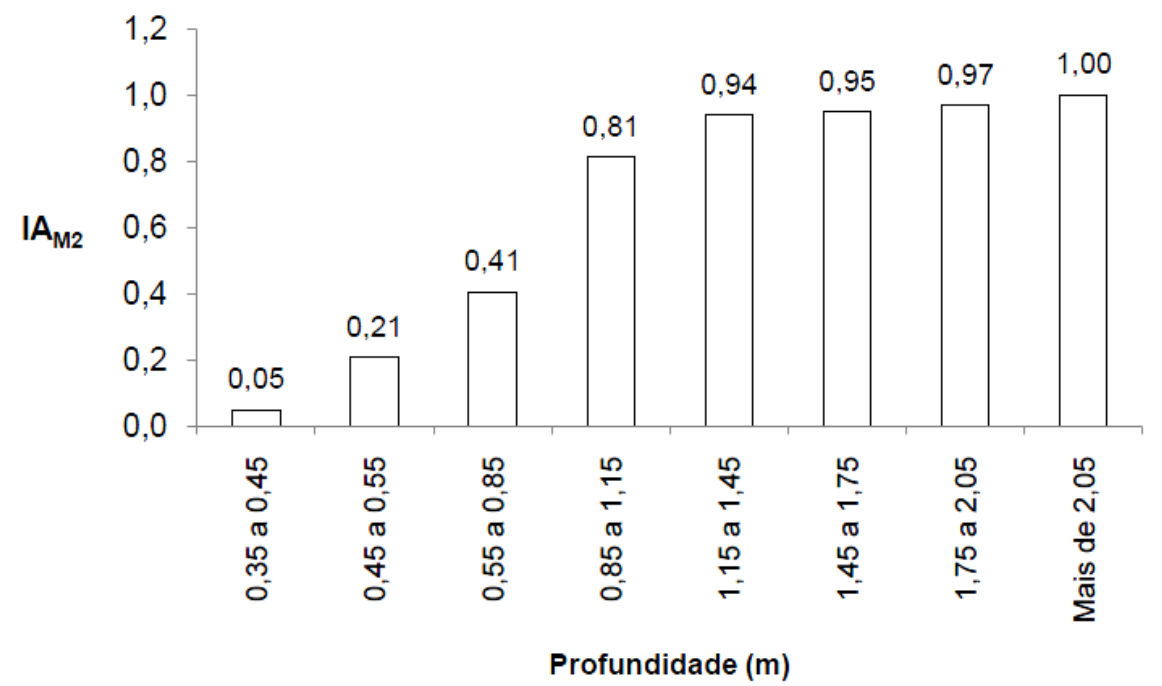

Figura 27 - Índice de ameaça da inundação ao conteúdo dos domicílios - IA $\mathrm{M}_{\mathrm{M} 2}$ Fonte: Cançado (2009) 
Na definição deste índice utiliza-se a profundidade como o fator de ameaça ao conteúdo das edificações. As escalas de profundidade foram definidas segundo os parâmetros apresentados em Penning-Rouwsell e Chatterton (1977) e adaptados para o Brasil por Machado (2005). Os índices foram utilizados para definir as profundidades críticas associadas à suscetibilidade dos diferentes bens ao contato com a água e utilizaram-se as curvas de suscetibilidade de cada bem estudado, sendo que a suscetibilidade varia segundo a profundidade. Pela Figura 27, percebe-se que a profundidade mínima considerada é de 0,35m, profundidade a qual foi considerado o início dos danos ao conteúdo.

Para melhor representatividade da curva de prejuízo e discretização dos resultados, os dados do índice de susceptibilidade apresentados na Figura 27 foram interpolados. Os índices de susceptibilidade de danos ao conteúdo pela profundidade de submersão utilizados neste trabalho são apresentados na Tabela13.

\begin{tabular}{c|c}
\hline $\begin{array}{c}\text { Tabela } 13 \text { - Índice de ameaça da inundação ao conteúdo } \\
\text { Profundidade } \\
\text { (em m) }\end{array}$ & Índice (\%) \\
\hline 0,35 a 0,45 & 0,05 \\
\hline 0,45 a 0,55 & 0,21 \\
\hline 0,55 a 0,70 & 0,31 \\
\hline 0,70 a 0,85 & 0,41 \\
\hline 0,85 a 0,95 & 0,54 \\
\hline 0,95 a 1,05 & 0,67 \\
\hline 1,05 a 1,15 & 0,79 \\
\hline 1,15 a 1,45 & 0,94 \\
\hline 1,45 a 1,75 & 0,95 \\
\hline 1,75 a 2,05 & 0,97 \\
\hline Mais de 2,05 & 1,00 \\
\hline
\end{tabular}

Estes índices foram aplicados aos imóveis residenciais e comerciais com o intuito de relacionar o valor do prejuízo encontrado através das curvas de danos por profundidade de submersão elaborada por Milograna (2009) com o percentual de susceptibilidade de perda por profundidade de submersão elaborado por Cançado (2009) para estimar a perda média sofrida pelos imóveis em cada evento, como serão mostrados posteriormente na Figura 72. As curvas elaboradas por Milograna (2009) encontram-se anexo a esse documento.

Pela Tabela 13, é possível verificar que alturas de submersão acima de 1,15 m representam mais de 94\% de susceptibilidade de prejuízo ao conteúdo dos imóveis. Desta 
forma, percebe-seque os valores de prejuízo dos imóveis a partir desta altura de submersão tornam-se próximo do máximo prejuízo alcançado.

\subsection{Quantificação dos prejuízos nos imóveis}

Para subsidiar as análises econômicas, foram elaborados inicialmente gráficos de dispersão que relacionam o prejuízo dos imóveis ao evento de precipitação. Nesta análise buscou-se mostrar os prejuízos ocorridos em cada evento de precipitação relacionados aos danos sofridos pelos imóveis de forma individual em seus respectivos cenários e tempo de retorno. Os danos por altura de submersão das empresas contidas na mancha de inundação são apresentados na Figura 28.

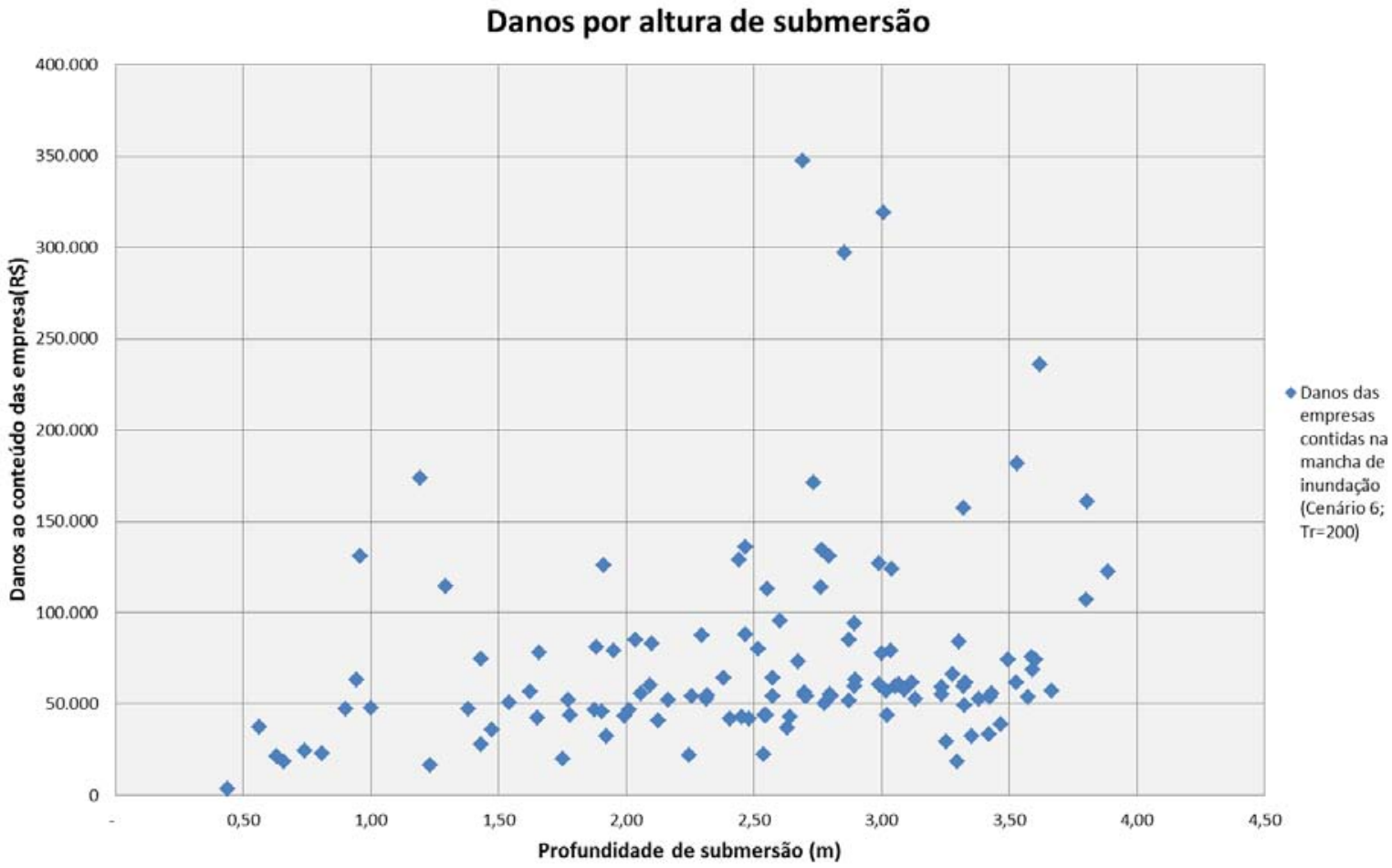

Figura 28 - Danos por profundidade de submersão das empresas contidas na mancha de inundação no cenário 6 (sem plano diretor) e $\mathrm{TR}=100$ anos

Devido a grande dispersão dos dados e impossibilidade de uma análise mais detalhada observada na Figura 28, optou-se por utilizar gráficos Boxplot para demonstrar a distribuição dos prejuízos das empresas e residências contidas na mancha de inundação.

O Boxplot (gráfico de caixa) é um gráfico utilizado para avaliar a distribuição empírica dos dados. É formado pelo primeiro e terceiro quartil, pela mediana e pelas hastes inferiores e superiores. As hastes se estendem, respectivamente, do quartil inferior (Q1) até o 
menor valor e do quartil superior (Q3) até o maior valor. Desta forma, os elementos presentes na caixa representam 50\% dos valores relacionados ao eixo da variável y, representados pelos limites de Q1 e Q3.

Outra característica do boxplot é que ele é um modo gráfico de expor outliers (valores extremos) presentes numa dada distribuição de valores ou de características, sendo o outlier uma observação que parece ser inconsistente com o restante de um conjunto de dados; neste caso, valores máximos e mínimos de prejuízo dos imóveis.

Os valores atípicos (outliers) são aqueles que excedem 1,5 vezes o intervalo interquartil. Dessa forma, os valores máximos são definidos pela equação 1, e os valores mínimos pela equação 2 .

$$
\begin{aligned}
& y=Q 3+1,5 *(Q 3-Q 1) \\
& y=Q 1-1,5 *(Q 3-Q 1)
\end{aligned}
$$

Assim, o boxplot é um retângulo com duas semi-retas ligando as suas extremidades, representas pelo $1^{\circ}$ quartil (Q1) e $3^{\circ}$ quartil (Q3), que representam $50 \%$ do total da amostra. Os quartis são ligados por valores mínimo e máximo representativos da amostra (valores que não contém outliers). Um exemplo esquemático de construção do gráfico boxplot é apresentado na Figura 29.

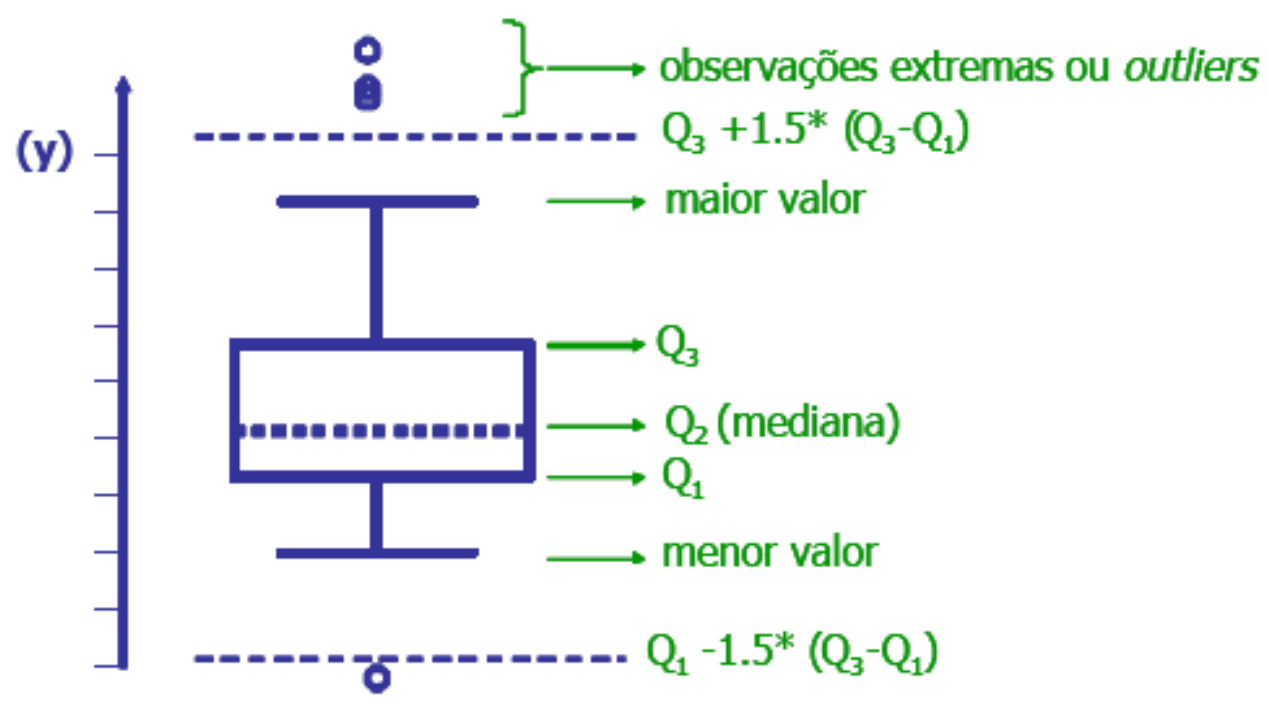

Figura 29 - Exemplo de gráfico boxplot Fonte: Atlas RM

Os elementos que constam na dispersão foram então incorporados em um gráfico boxplot para estabelecer seus respectivos quartis Q1 e Q3, mediana, máximo e mínimo. Nesta primeira etapa, não foram excluídos os valores de outliers. O gráfico boxplot com todos os elementos é exemplificado na Figura 30. 


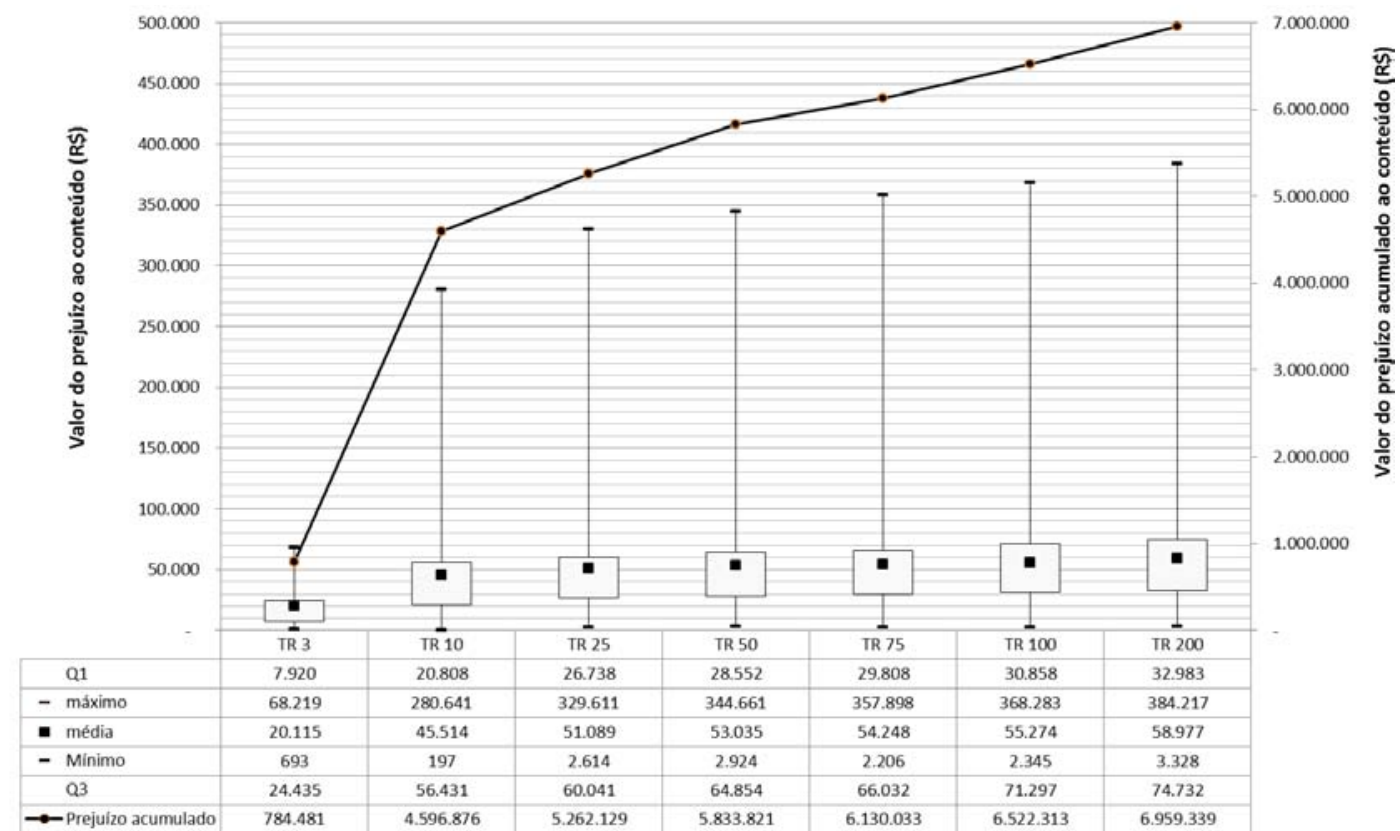

Figura 30 - Exemplo de gráfico boxplot construído sem a exclusão dos outliers

Pelo gráfico é possível notar a falta de homogeneidade da amostra, com valores de máximo extremamente discrepantes, que geraram valores extremos e pouco conclusivos sobre a amostra. Com relação aos valores discrepantes de mínimo (abaixo do $1^{\circ}$ quartil), não foram verificadas a presença de outliers em nenhum evento, caracterizados pelos valores abaixo dos estabelecidos pela Equação 1. Desta forma, procedeu-se a exclusão dos valores extremos máximos para homogeneizar a amostra.

Para excluir os valores extremos, inicialmente foi aplicada a Equação 1 a dispersão de dados de modo a identificar os elementos extremos, como mostrado nas Figuras 31 e 32. O valor limite da Equação 1 foi de R\$ 135.000,00. 


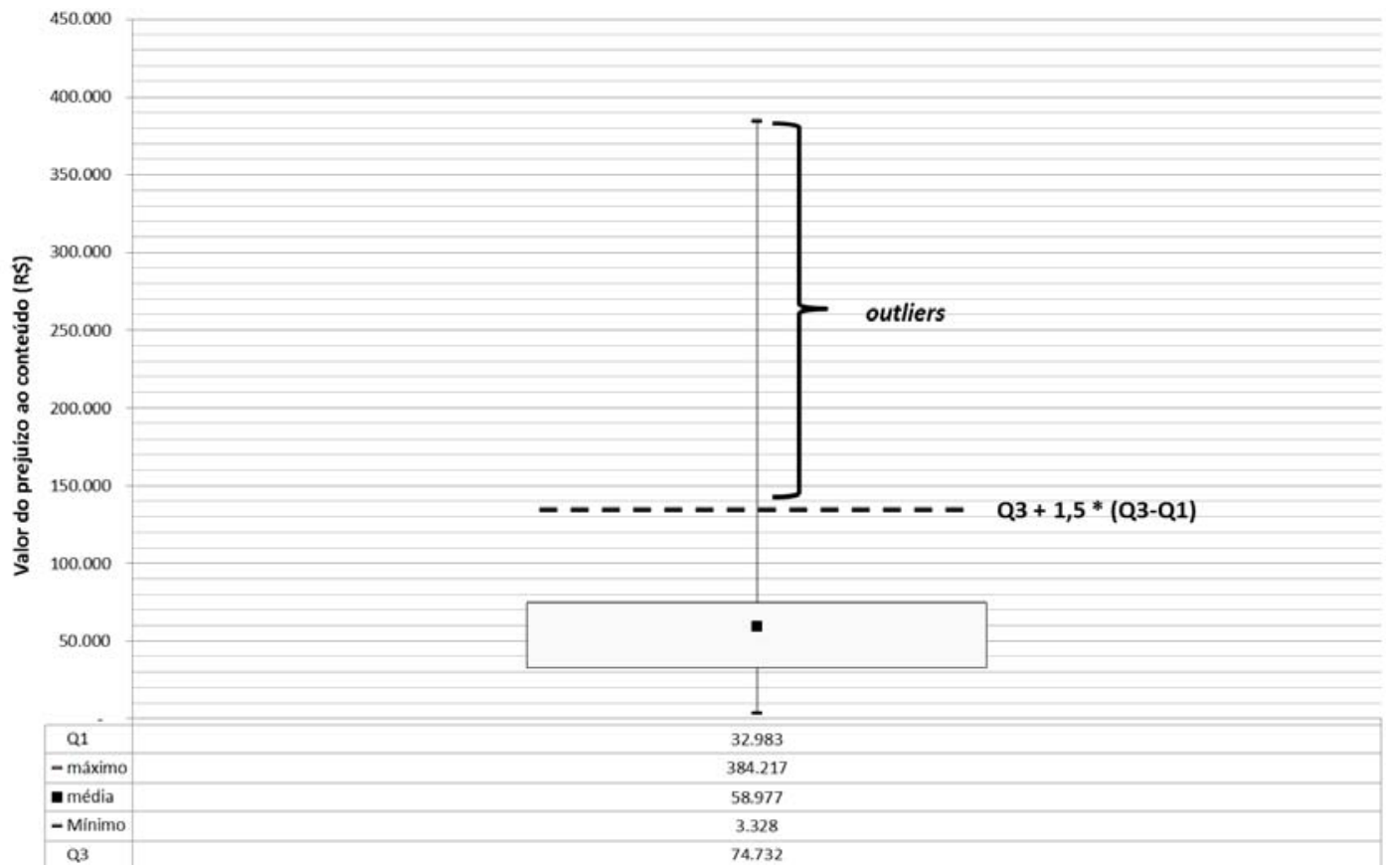

Figura 31 - Gráfico boxplot com todos os elementos (empresas) presentes

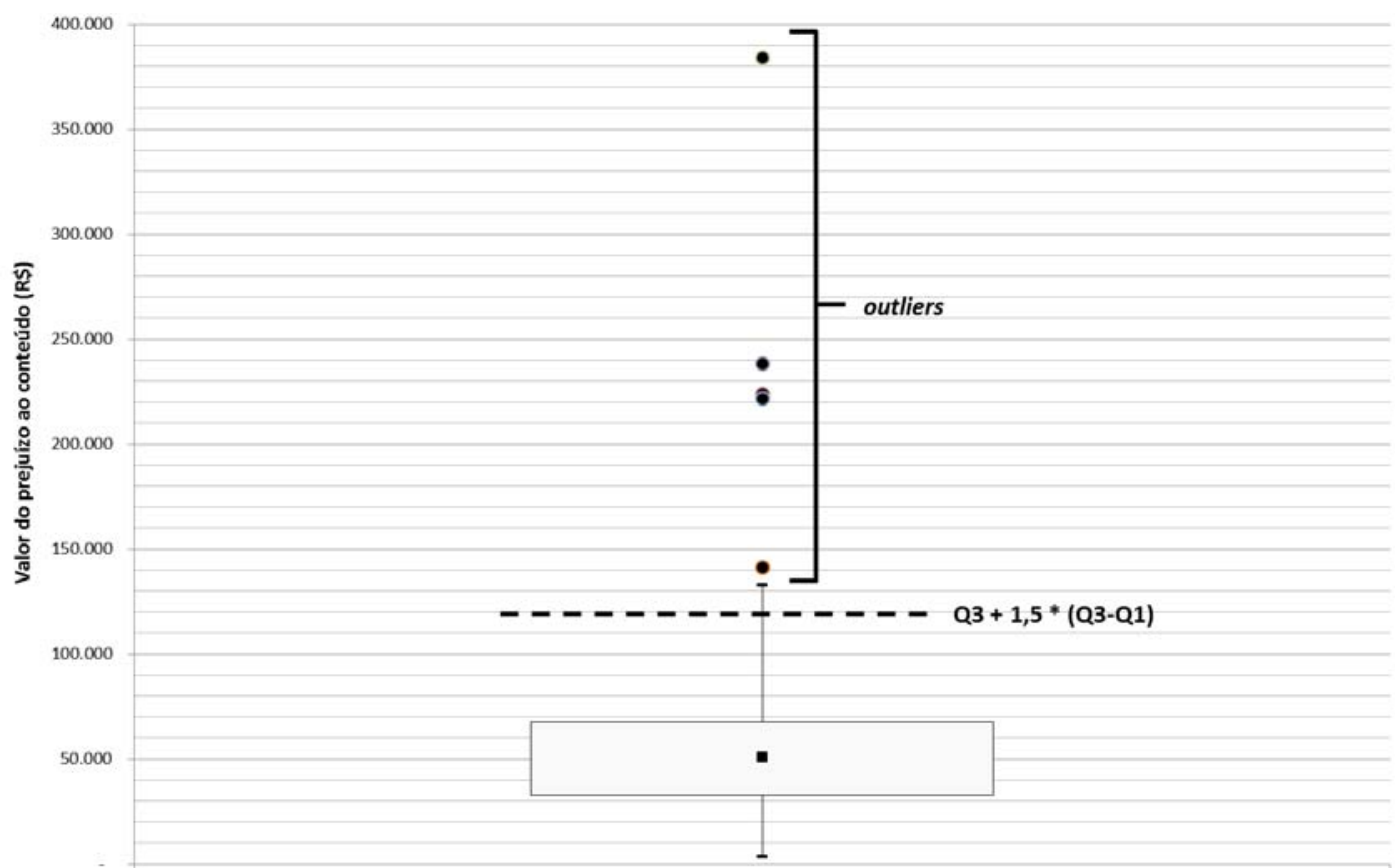

Figura 32 - Gráfico boxplot com detalhes das empresas acima do valor máximo na 1ª análise

Pela Figura 32, é possível notar a presença de cinco empresas com valores superiores ao máximo para o limite superior. Essas empresas foram excluídas da análise e, dessa forma, uma nova linha de limite superior foi estabelecida, agora com a exclusão das cinco empresas outliers desta análise. A nova linha de limite superior é gerada pelos novos valores de quartis presentes na amostra, portanto a exclusão dessas empresas gerou a redução do limite superior de $\mathrm{R} \$ 135.000,00$ para $\mathrm{R} \$ 120.000,00$ (Figura 32). Uma nova análise possibilitou notar que duas novas empresas foram consideradas outliers, sendo também excluídas da amostra. As 
novas empresas que se enquadraram acima do novo limite superior aumentaram o total de outliers de 5 para 7 empresas no exemplo, conforme Figura 33.

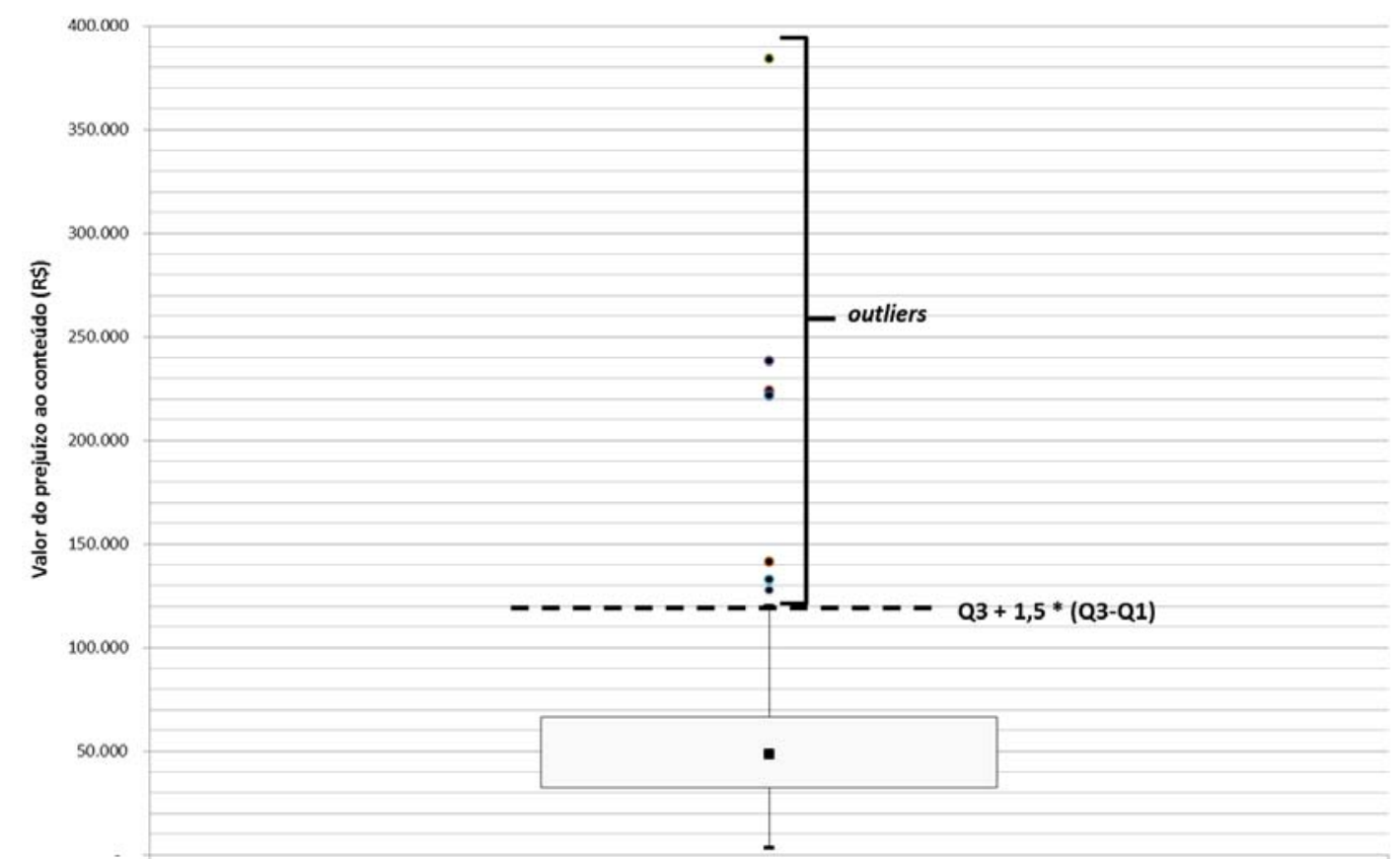

Figura 33 - Gráfico boxplot com detalhes das empresas acima do valor máximo na $2^{\mathrm{a}}$ análise

Após a exclusão dessas empresas, não houveram outras empresas acima do limite máximo estabelecido pela Equação 1 para o quartil superior, encerrando a análise. Um exemplo de gráfico boxplot gerado após a exclusão dos outliers é apresentado na Figura 34.

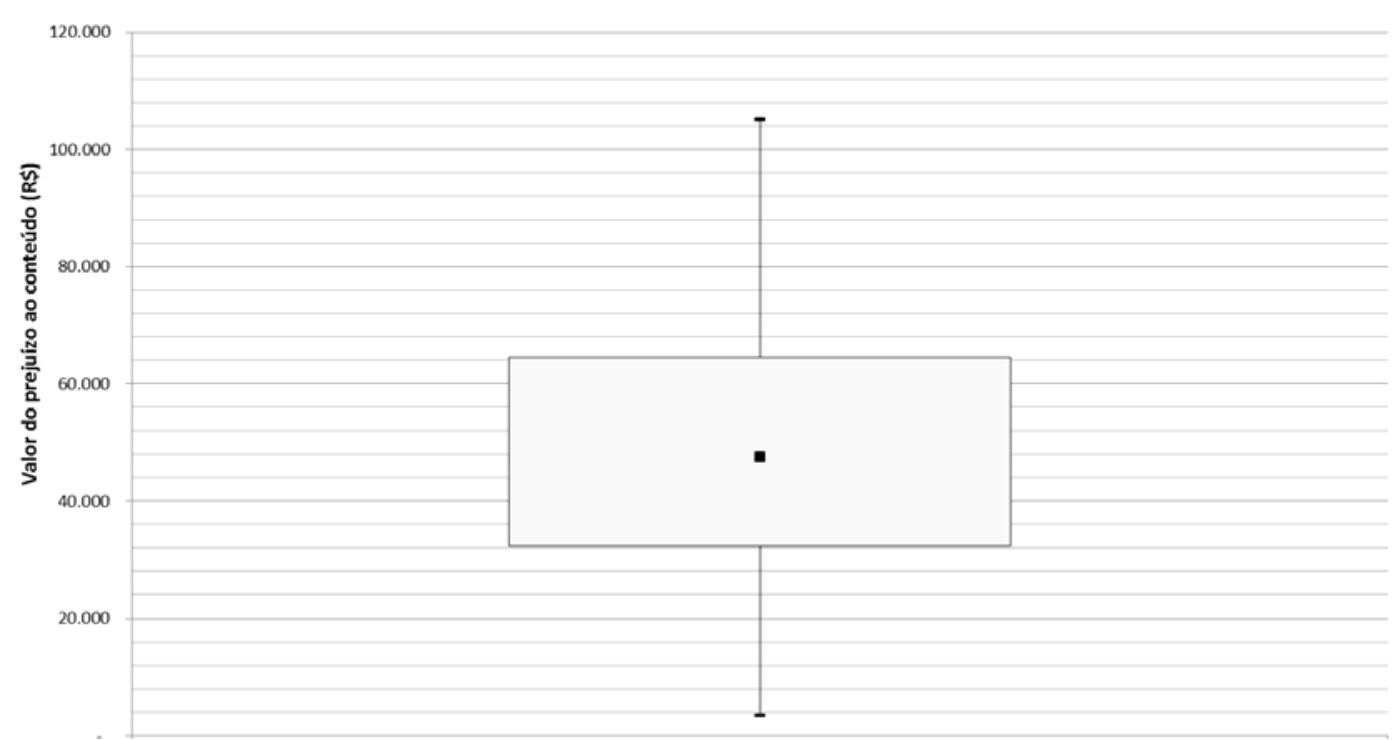

Figura 34 - Gráfico boxplot após a exclusão dos outliers

Essa análise foi elaborada para todos os 36 eventos de imóveis comerciais considerados nesta pesquisa, sendo 18 eventos pelo método dos blocos alternados e 18 
eventos pelo método de Huff $1^{\circ}$ quartil, foco desta pesquisa. Para as residências, não foram observados outliers.

\subsection{Banco de dados}

A partir das informações apresentadas foi construído um banco de dados no Microsoft Excel e importada para o ArcGis 9.3. Foram considerados 3 tempos de retorno para o método de Huff $1^{\circ}$ quartil e 3 tempos de retorno para o método dos blocos alternados e 6 cenários distintos para 2 categorias de imóveis (residências e comerciais), o que resultou num banco de dados com 72 planilhas.

A base de dados em cada planilha contém os seguintes itens:

\section{Residências:}

$\checkmark$ Número de identificação (ID);

$\checkmark$ Padrão estrutural do imóvel (baixo, médio, alto) para determinação da classe econômica;

$\checkmark$ Altura da lâmina de água (m);

$\checkmark$ Classe econômica (A, B, C/D)

$\checkmark$ Prejuízo ao conteúdo (R\$)

\section{Empresas:}

$\checkmark \quad$ Número de identificação (ID);

$\checkmark$ Altura da lâmina de água (m);

$\checkmark$ Logradouro da empresa;

$\checkmark$ Nome da empresa;

$\checkmark$ Classificação por atividade (classificação de acordo com Milograna (2009);

$\checkmark$ Área do imóvel $\left(\mathrm{m}^{2}\right)$;

$\checkmark$ Índice de ameaça da inundação ao conteúdo - IA $\mathrm{IM}_{\mathrm{M} 2}$ (Cançado, 2009);

$\checkmark \quad$ Prejuízo do estoque (R\$) 


\section{RESULTADOS E DISCUSSÕES}

\subsection{Hidrogramas de cheias}

Os hidrogramas de cheias foram obtidos a partir da modelação hidrológica realizada com o modelo HEC-HMS. Exemplos de hidrogramas de cheia utilizando o método de distribuição de chuva de blocos alternados e de Huff $1^{\circ}$ quartil elaborado pelo software são apresentados, respectivamente, nas Figuras 35 e 36.
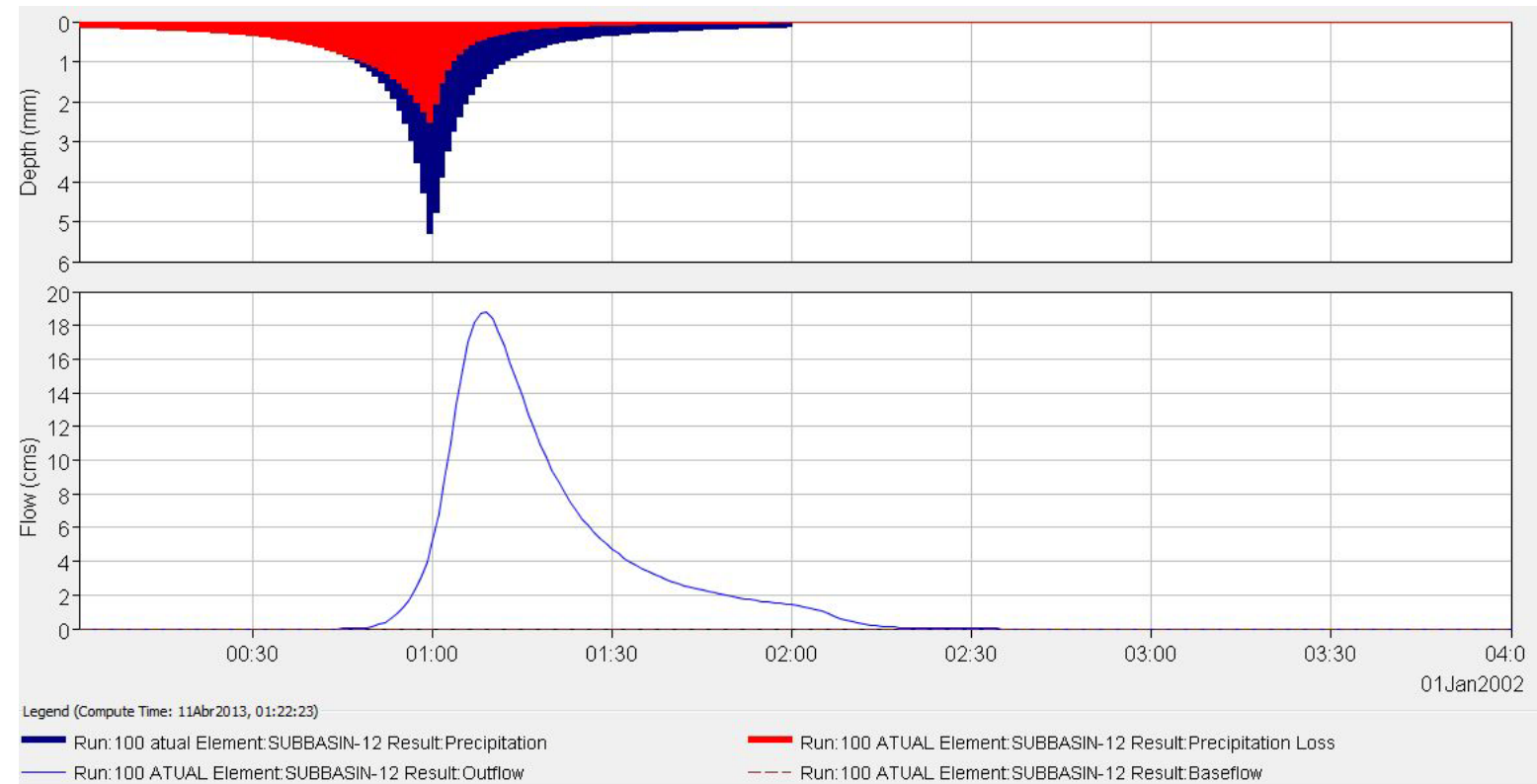

Figura 35 - Exemplo hidrograma de cheia obtido pelo software Hec-HMS para a sub-bacia 12 no cenário atual com tempo de retorno de 100 anos sob método de distribuição temporal blocos alternados 


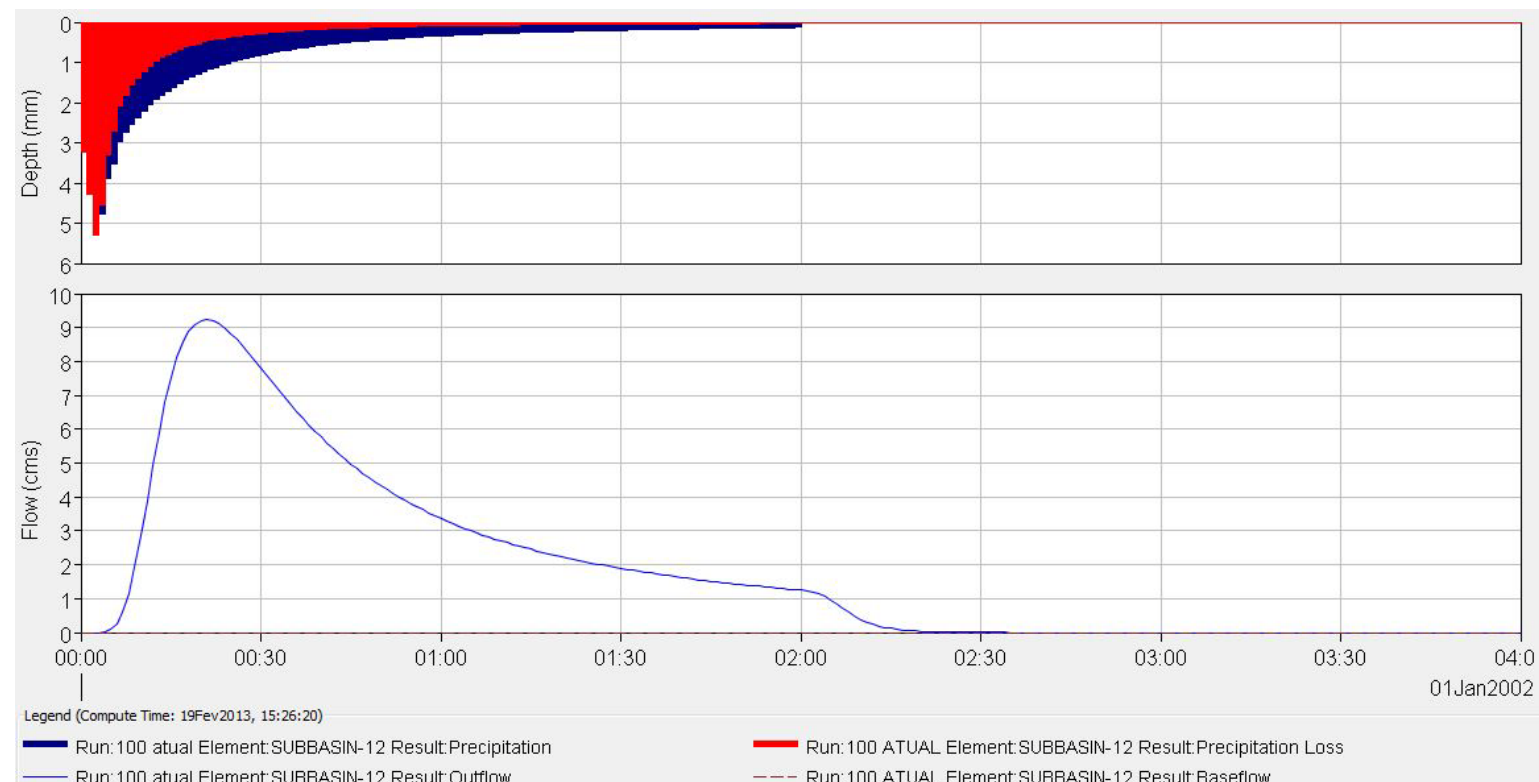

Figura 36 - Exemplo hidrograma de cheia obtido pelo software Hec-HMS para a sub-bacia 12 no cenário atual com tempo de retorno de 100 anos sob método de distribuição temporal Huff $1^{\circ}$ Quartil

Nas Figuras 35 e 36 são mostrados os resultados de escoamento superficial em uma das sub-bacias, cuja linha inferior refere-se ao hidrograma de cheia da localizada sub-bacia 12, cuja localização pode ser observada pela Figura 16; na parte superior do gráfico, a faixa vermelha representa o total infiltrado (precipitation loss) e a parte azul a precipitação efetiva.

Pelas figuras, podemos notar que, do volume de água total precipitado pelos dois métodos, o método dos blocos alternados gerou um volume maior de escoamento superficial e consequentemente um pico de vazão maior no hidrograma, quando comparado ao método de Huff $1^{\circ}$ quartil.

As figuras mostram que pelo método de Huff $1^{\circ}$ quartil, o hidrograma de cheia obteve aproximadamente a metade $\left(\approx 9 \mathrm{~m}^{3} / \mathrm{s}\right.$ ) do valor de pico quando comparado ao método dos blocos alternados ( $\left.\approx 19 \mathrm{~m}^{3} / \mathrm{s}\right)$. Isso pode ser explicado pela maior capacidade de infiltração do solo no começo da precipitação, conforme explica Viessman, Lewis e Knapp (1989).

O potencial do gradiente hidráulico do solo no inicio da chuva é elevado, porque a frente de umedecimento permanece praticamente na superfície do solo. Entretanto, inicialmente, a taxa de infiltração do solo é maior que a intensidade da precipitação, com o fornecimento contínuo das águas precipitadas, a zona de umedecimento aumenta e a taxa de infiltração é reduzida, neste momento ocorre a saturação da superfície do solo, gerando o escoamento superficial (VIESSMAN, LEWIS e KNAPP, 1989).

Através dos resultados gerados pelo HEC-HMS para cada cenário e tempo de retorno, foram elaborados hidrogramas de modo a comparar os métodos de distribuição de chuva aplicados neste estudo. Os resultados são mostrados nas Figuras 37 a 42, os quais 
apresentam uma comparação da vazão de pico obtida pelos dois métodos em cada cenário. Os hidrogramas são provenientes do exutório da sub-bacia 12 (Figura 16).

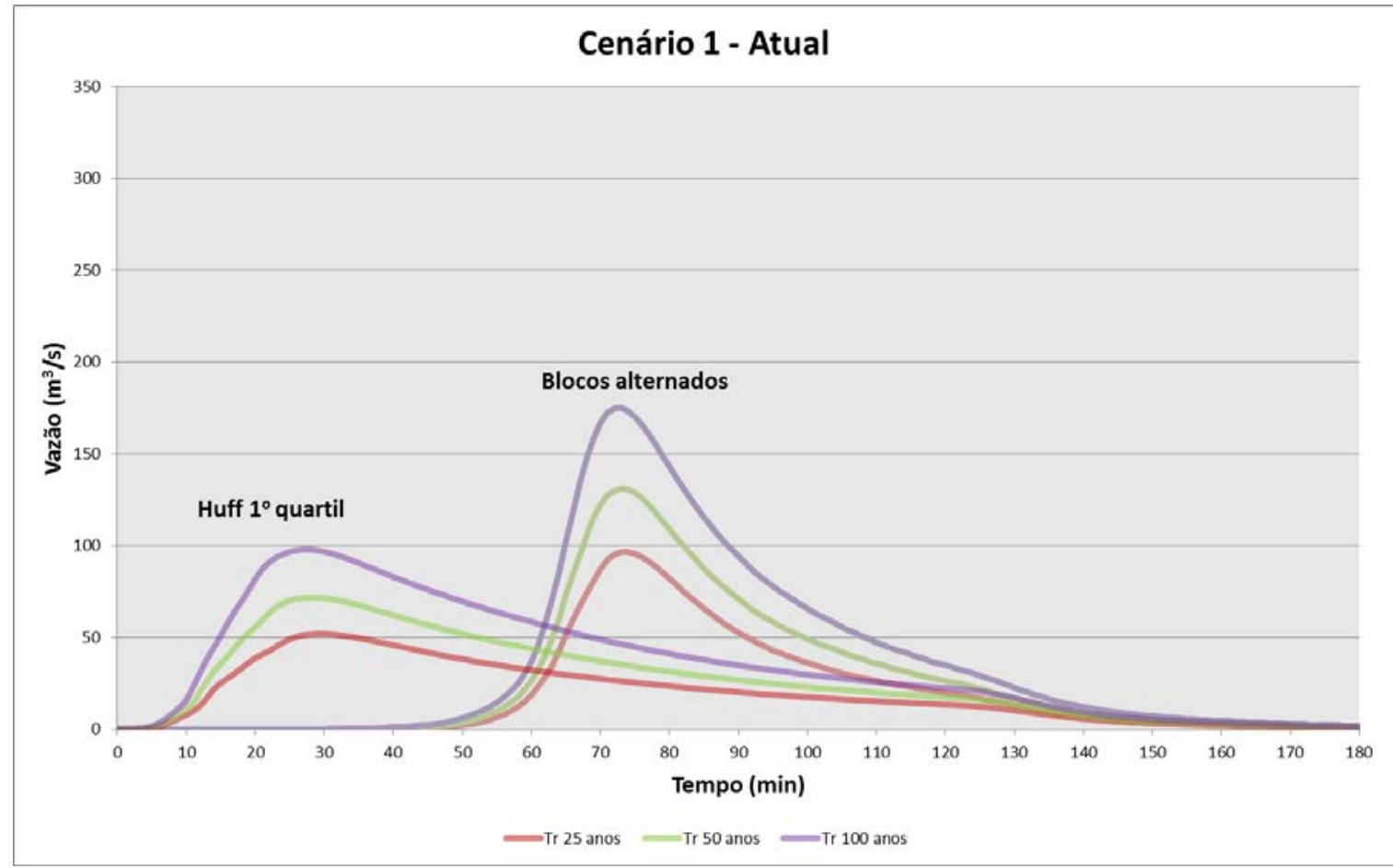

Figura 37 - Comparação entre as vazões pelos métodos de distribuição de Huff $1^{\circ}$ quartil e blocos alternados no cenário 1 (atual)

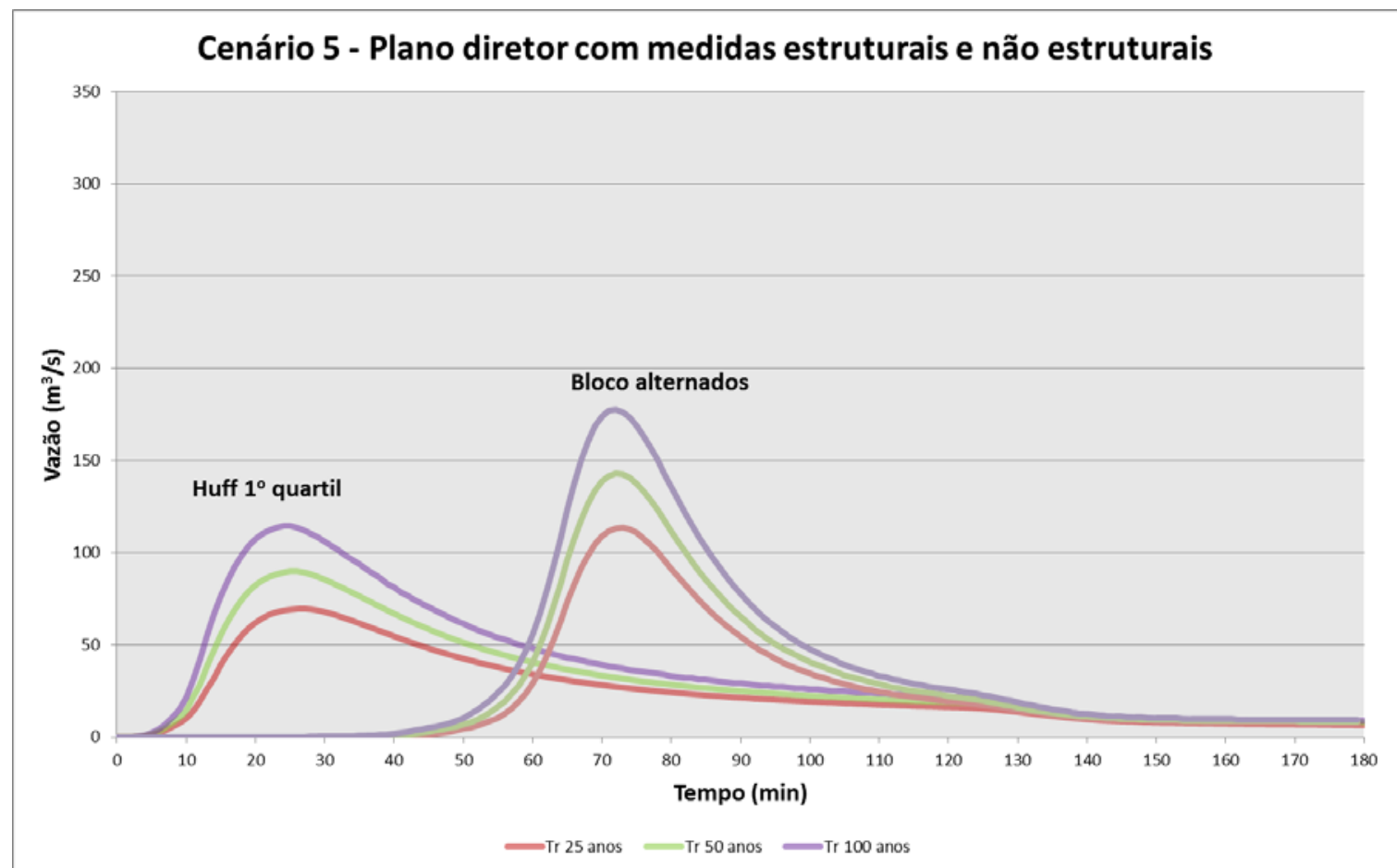

Figura 38 - Comparação entre as vazões pelos métodos de distribuição de Huff $1^{\circ}$ quartil e blocos alternados no cenário 5 (plano diretor, medidas estruturais e não estruturais) 


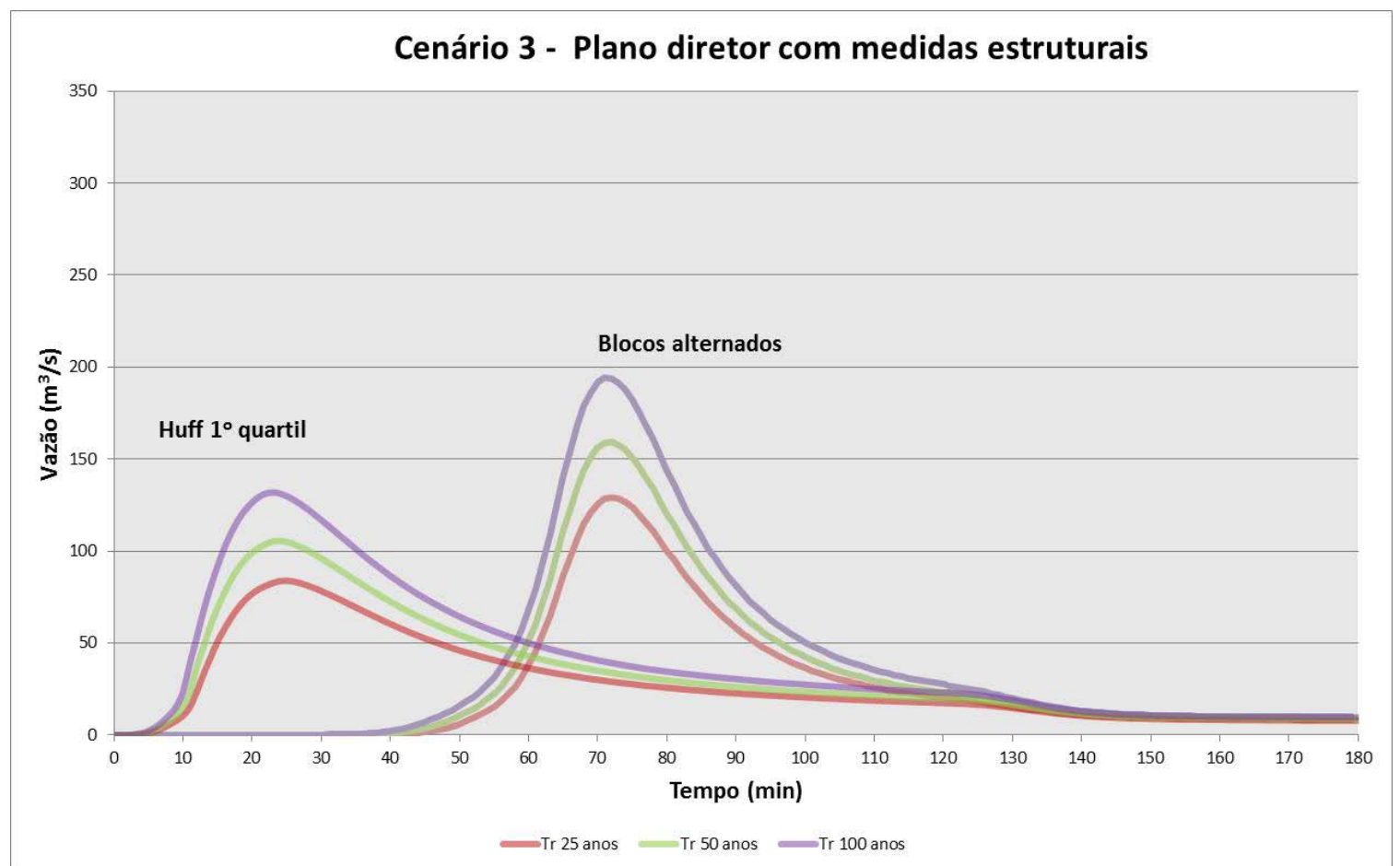

Figura 39 - Comparação entre as vazões pelos métodos de distribuição de Huff $1^{\circ}$ quartil e blocos alternados no cenário 3 (Plano diretor e medidas estruturais)

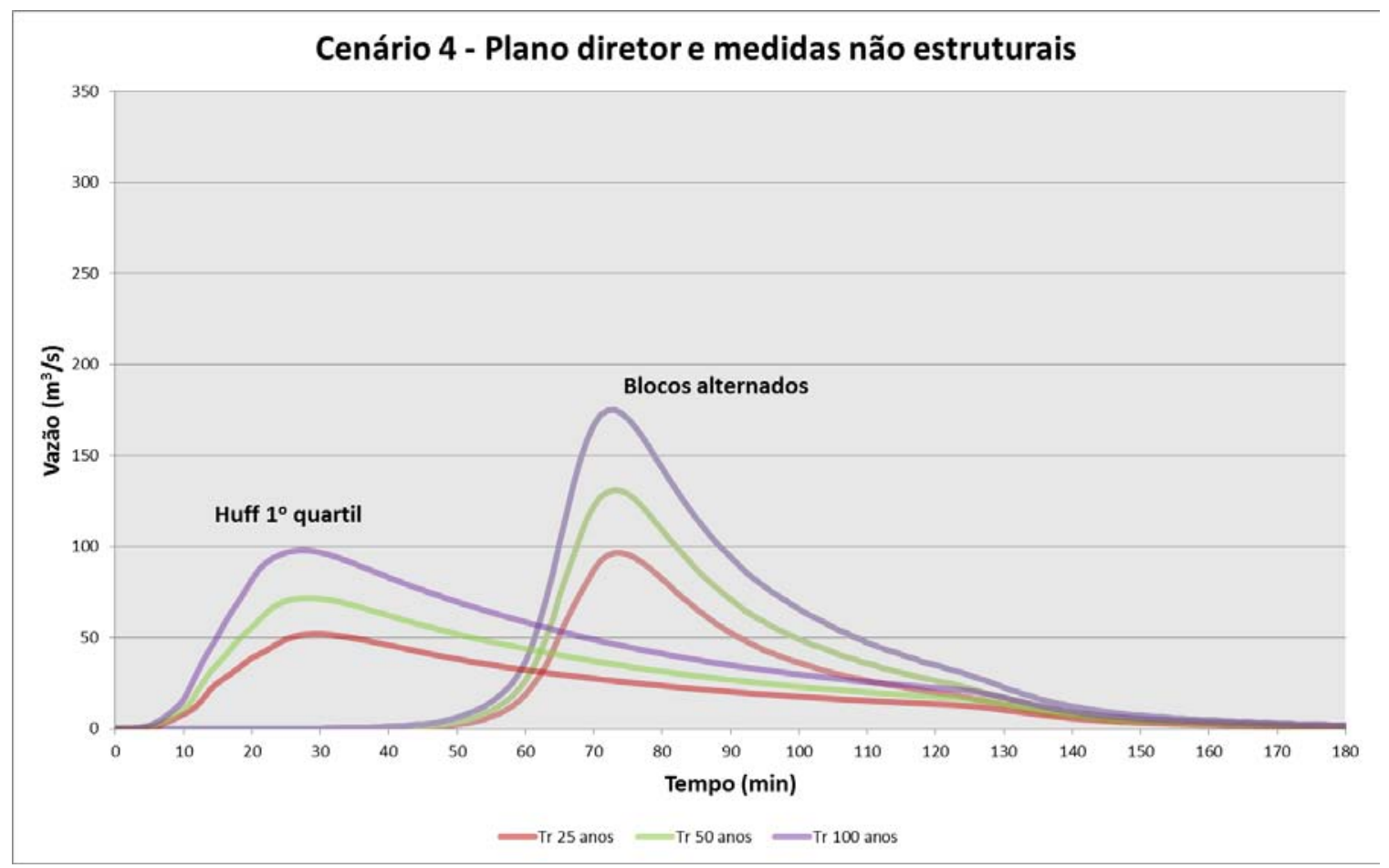

Figura 40 - Comparação entre as vazões pelos métodos de distribuição de Huff $1^{\circ}$ quartil e blocos alternados no cenário 4 (Plano diretor e medidas não estruturais) 


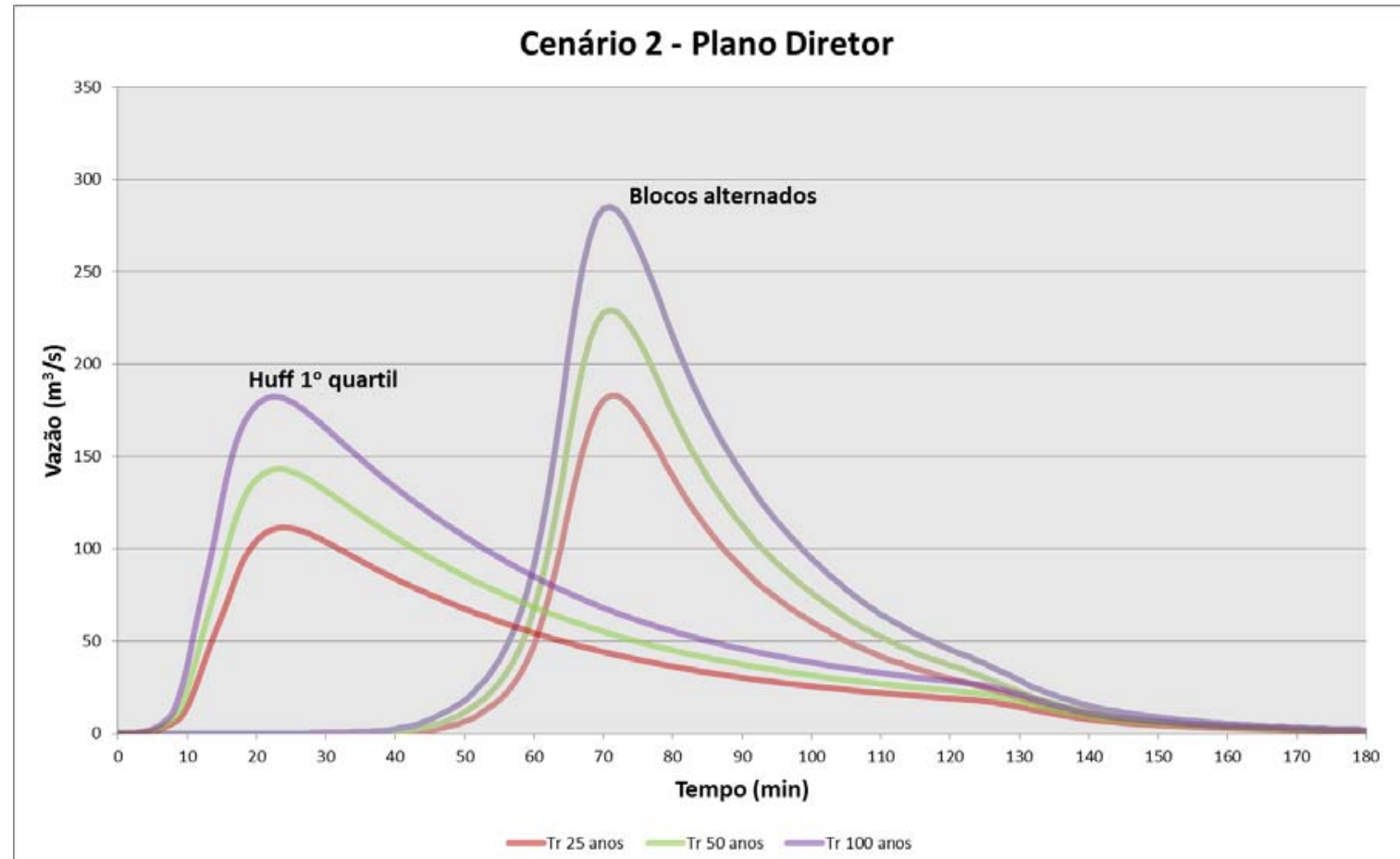

Figura 41 - Comparação entre as vazões pelos métodos de distribuição de Huff $1^{\circ}$ quartil e blocos alternados no cenário 2 (Plano diretor)

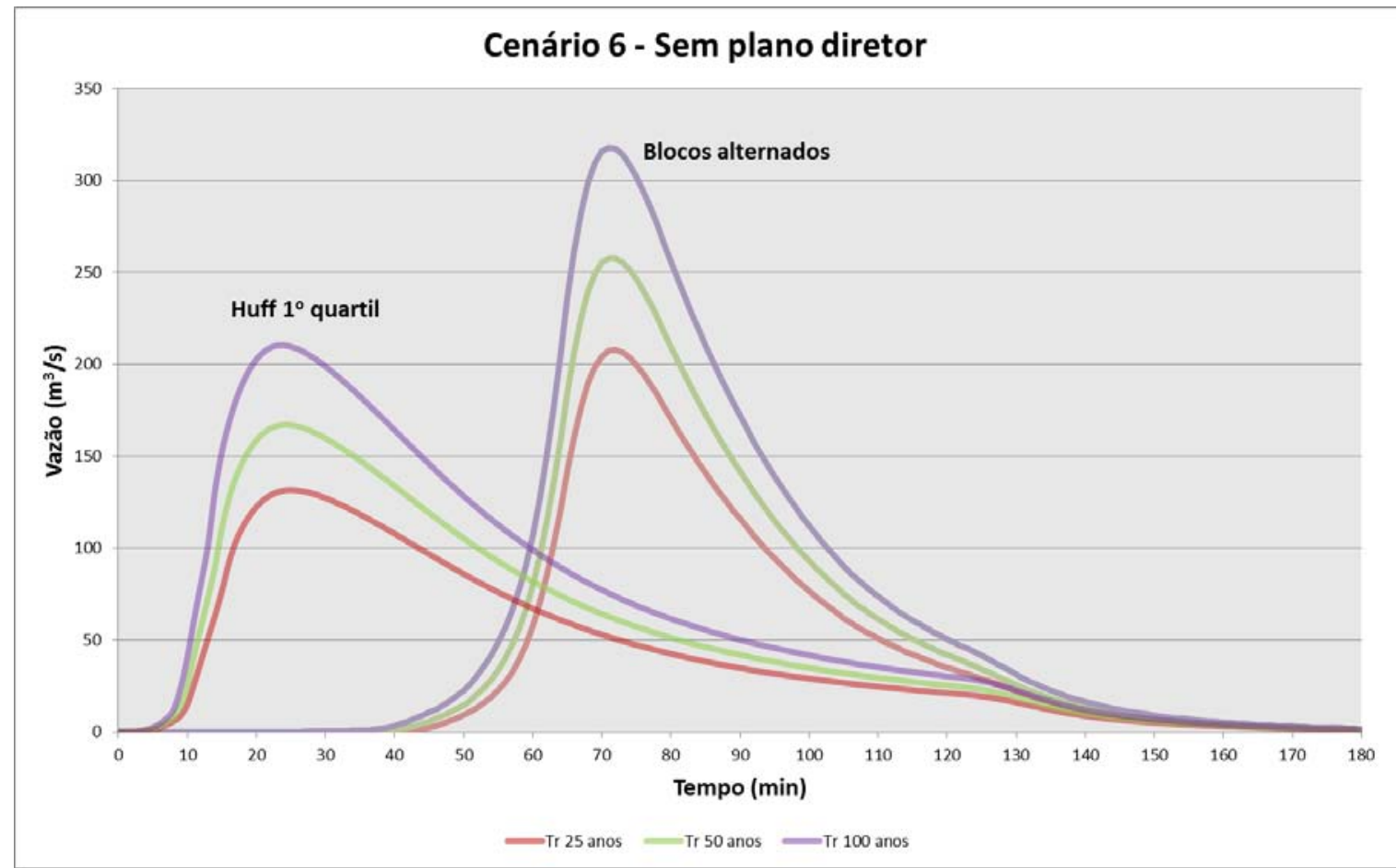

Figura 42 - Comparação entre as vazões pelos métodos de distribuição de Huff $1^{\circ}$ quartil e blocos alternados no cenário 6 (Sem plano diretor)

É possível perceber pelos gráficos que os maiores picos de vazão de escoamento superficial foram obtidos com a utilização do método dos blocos alternados com pico na 
metade da duração da chuva. O comparativo entre as vazões máximas obtidas pelos dois métodos é apresentado na Figura 43.

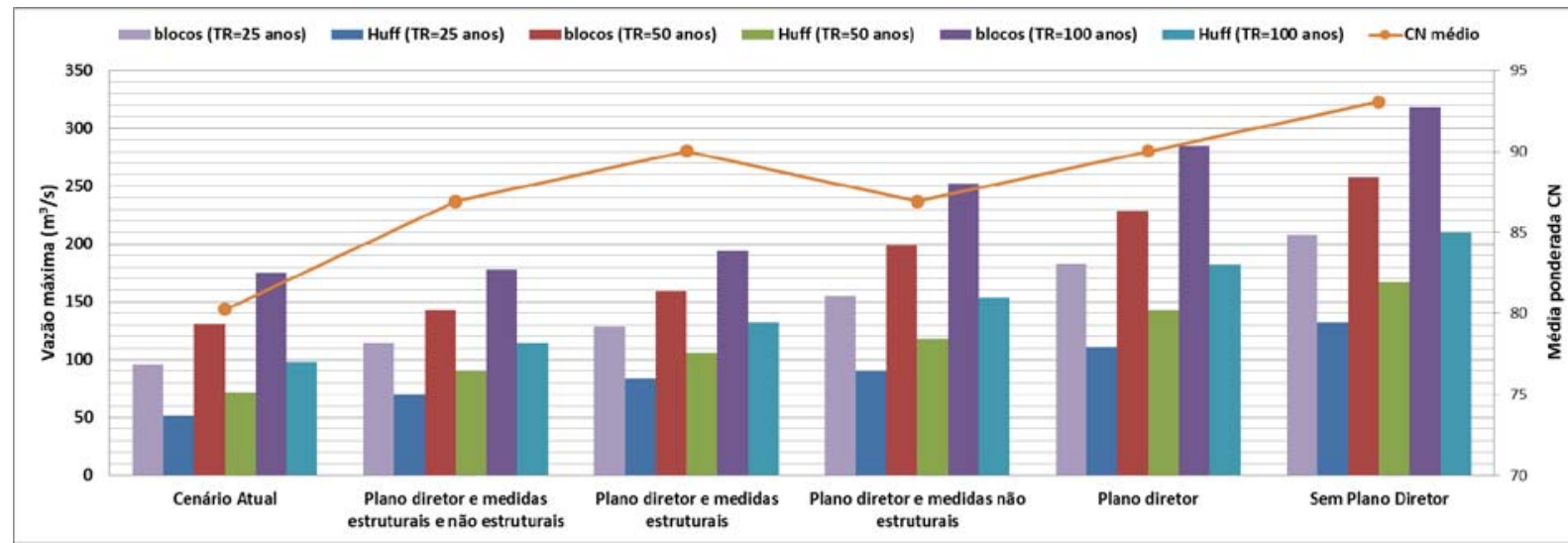

Figura 43 - Comparação entre a vazão máxima obtida pelos métodos de Huff $1^{0}$ quartil e blocos alternados

Pela Figura 43 é possível perceber as diferenças entre os métodos de modo a relacioná-los com os valores de CN obtidos por média ponderada das áreas das sub-bacias em cada cenário. O cenário "plano diretor e medidas não estruturais" e "plano diretor e medidas estruturais e não estruturais” foram modelados utilizando o mesmo valor de $\mathrm{CN}$, assim como os cenários "Plano diretor e medidas estruturais" e "plano diretor".

Para mostrar as variações no escoamento superficial gerados pelos dois métodos, são apresentas na Tabela 14 as variações entre as vazões máximas obtidas pelo Hec-HMS para os dois métodos em termos percentuais. Essas diferenças são apresentadas para os períodos de retorno de 25, 50 e 100 anos. A coluna variação refere-se a diferença de aumento relativo entre os métodos de blocos alternados e Huff $1^{\circ}$ quartil.

$$
\text { Variação }=\frac{\left(\text { Blocos alternados }-H u f f 1^{o} \text { quartil }\right)}{(\text { Blocos alternados })} * 100
$$

Tabela 14 - Comparação entre as vazões máximas $\left(\mathrm{m}^{3} / \mathrm{s}\right)$ dos hidrogramas calculados para a área de estudo

\begin{tabular}{|c|c|c|c|c|c|c|c|c|c|c|}
\hline \multirow{3}{*}{ CENÁRIOS } & \multicolumn{3}{|c|}{ Blocos alternados } & \multicolumn{3}{|c|}{ Huff $1^{\circ}$ quartil } & \multicolumn{3}{|c|}{ Variação (\%) } & CN \\
\hline & \multicolumn{3}{|c|}{$\begin{array}{l}\text { Tempo de retorno } \\
\text { (anos) }\end{array}$} & \multicolumn{3}{|c|}{$\begin{array}{l}\text { Tempo de retorno } \\
\text { (anos) }\end{array}$} & \multicolumn{3}{|c|}{$\begin{array}{l}\text { Tempo de retorno } \\
\text { (anos) }\end{array}$} & \multirow{2}{*}{$\begin{array}{c}\text { Média } \\
\text { Ponderada } \\
\text { das sub- } \\
\text { bacias }\end{array}$} \\
\hline & 25 & 50 & 100 & 25 & 50 & 100 & 25 & 50 & 100 & \\
\hline Cenário Atual & 96 & 131 & 175 & 52 & 72 & 98 & 46 & 45 & 44 & 80 \\
\hline Plano diretor e medidas não estruturais & 155 & 199 & 252 & 90 & 118 & 154 & 42 & 40 & 39 & 87 \\
\hline Plano diretor & 183 & 229 & 285 & 111 & 143 & 182 & 39 & 38 & 36 & 90 \\
\hline Sem Plano Diretor & 208 & 258 & 318 & 132 & 167 & 210 & 37 & 35 & 34 & 93 \\
\hline $\begin{array}{l}\text { Plano diretor e medidas estruturais e não } \\
\text { estruturais }\end{array}$ & 114 & 143 & 178 & 70 & 90 & 114 & 39 & 37 & 36 & 87 \\
\hline Plano diretor e medidas estruturais & 129 & 159 & 194 & 84 & 106 & 132 & 35 & 34 & 32 & 90 \\
\hline
\end{tabular}


Pela tabela, é possível perceber aumentos na vazão de pico entre 32\% (Plano diretor e medidas estruturais; $\mathrm{TR}=100$ anos) a 46\% (cenário atual; TR= 25 anos) entre os mesmos eventos modelados pelos dois métodos comparados, ou seja, a vazão de pico utilizando o método blocos alternados possui até $46 \%$ de aumento de vazão de pico em relação ao método de Huff $1^{\circ}$ quartil para o mesmo cenário e tempo de retorno analisado. É possível perceber também a baixa variação entre o porcentual de aumento dos diferentes tempos de retorno no respectivo cenário, os quais não variaram mais do que 3\%, o que evidencia uma proporcionalidade entre os métodos.

Percebe-se também que os valores obtidos de vazões máximas com tempo de retorno de 25 anos para os blocos alternados são semelhantes aos obtidos para o mesmo cenário com tempo de retorno de 100 anos pelo método de Huff em todos os cenários, fato que evidencia a grande sensibilidade do modelo quanto ao método de distribuição de chuva.

A comparação entre os porcentuais de aumento de vazão para os dois métodos relacionados com o valor de $\mathrm{CN}$ mostram que, quanto menor o valor de $\mathrm{CN}$, maiores são as diferenças no incremento de vazão de um método para o outro, conforme Tabela 14.

Essa constatação foi observada para os três períodos de retorno estudados. Para exemplificar, no TR de 100 anos, o cenário atual (com valor de CN de 80) obteve um aumento porcentual de $44 \%$ em relação aos métodos de distribuição da chuva, ao passo que no cenário sem plano diretor (com CN de 93) esse aumento foi de 32\%.

Para os cenários que contém reservatórios (cenário “plano diretor e medidas estruturais e não estruturais" e "plano diretor e medidas estruturais”) essas diferenças também foram observadas, com incremento de 39\% e 35\% para $\mathrm{CN}$ médio de 87 e 90, respectivamente.

De acordo com o Manual de Drenagem e Manejo de Águas Pluviais de São Paulo (2012), o tipo de distribuição temporal das chuvas de projeto e a fixação da duração estão sujeitas a diversas orientações metodológicas, implicando em resultados de descargas máximas e volumes de cheias que podem ser bastante discrepantes. Destaca também que em projetos de bacias urbanas mais comuns desenvolvidos no nosso meio, tem sido adotado na maioria das vezes, chuvas com duração de 2 ou 3 horas e distribuição conforme o método dos blocos alternados ou o método de Huff $1^{\circ}$ quartil. Somente para bacias com áreas maiores de $100 \mathrm{~km}^{2}$ tem-se adotado chuvas de 6 horas e distribuição dos blocos alternados ou Huff $2^{\circ}$ quartil.

Assim, conclui-se que a alteração do método de distribuição temporal das chuvas pode trazer incertezas quanto à transformação da chuva em vazão e, dessa forma, introduzir 
diferenças significativas nos resultados. Porém, é possível perceber que essas diferenças possuem correlação direta com o valor de CN obtido pela bacia, de modo a estabelecer tendências quanto a essa variável.

\subsection{2. Área da mancha de inundação}

Foram mensuradas as áreas de abrangência da mancha de inundação em cada evento pelos dois métodos de distribuição temporal das chuvas, para comparar o seu impacto do ponto de vista geográfico. O gráfico comparativo das áreas das manchas de inundação é apresentado na Figura 44 e valores das áreas de abrangência da mancha de inundação em cada cenário proposto com seu respectivo aumento porcentual e valores de CN na Tabela 15.

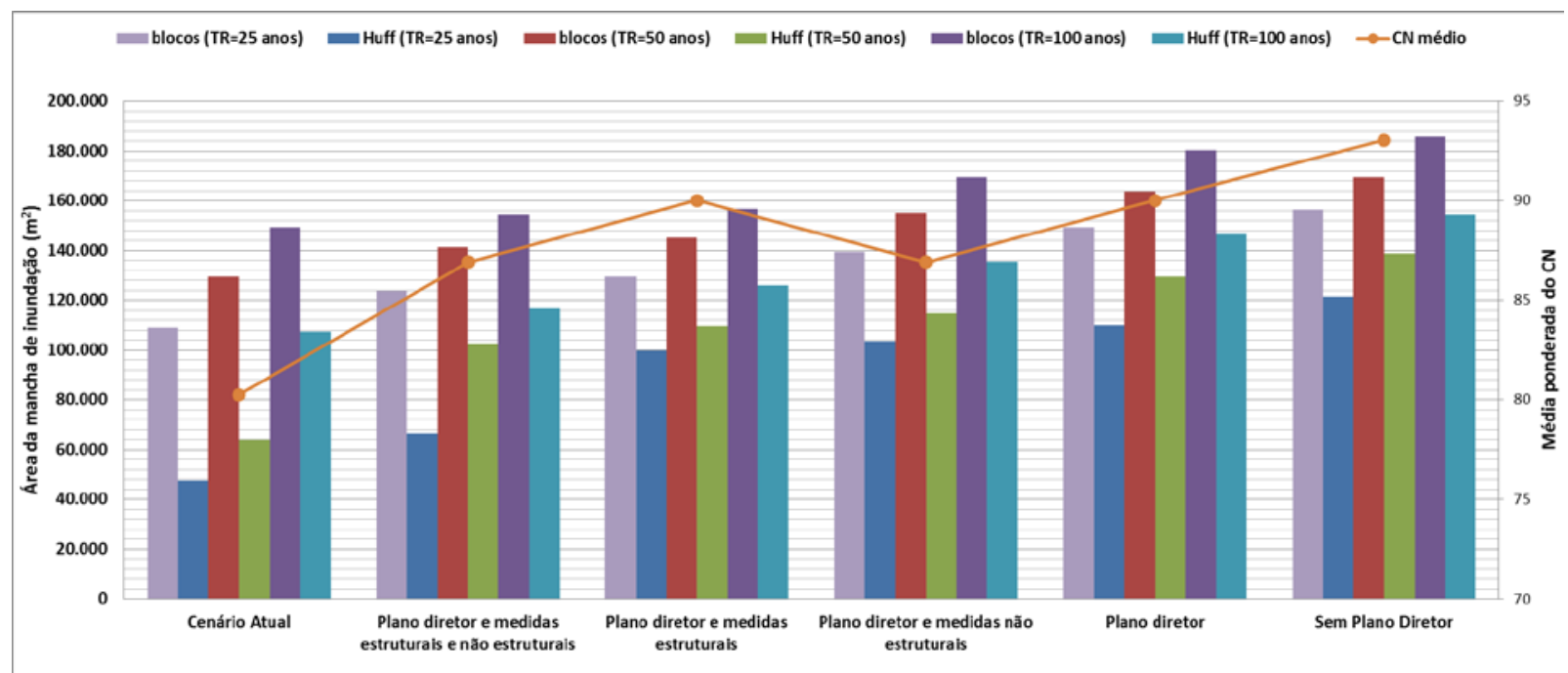

Figura 44 - Comparação entre a área de abrangência da mancha de inundação pelos métodos de distribuição temporal blocos alternados e Huff $1^{\circ}$ quartil

Tabela 15 - Área das manchas de inundação de acordo com o tempo de retorno, cenário e método de distribuição temporal da precipitação

\begin{tabular}{|c|c|c|c|c|c|c|c|c|c|c|}
\hline \multirow{4}{*}{ CENÁRIO } & \multicolumn{3}{|c|}{ Blocos alternados } & \multicolumn{3}{|c|}{ Huff $1^{\circ}$. Quartil } & \multicolumn{3}{|c|}{ Variação (\%) } & $\mathbf{C N}$ \\
\hline & \multicolumn{3}{|c|}{ Tempo de retorno (anos) } & \multicolumn{3}{|c|}{ Tempo de retorno (anos) } & \multicolumn{3}{|c|}{$\begin{array}{c}\text { Tempo de retorno } \\
\text { (anos) }\end{array}$} & \multirow{3}{*}{$\begin{array}{c}\text { Média } \\
\text { ponderada } \\
\text { das sub- } \\
\text { bacias }\end{array}$} \\
\hline & 25 & 50 & 100 & 25 & 50 & 100 & 25 & 50 & 100 & \\
\hline & \multicolumn{3}{|c|}{ Área de abrangência $\left(\mathrm{m}^{2}\right)$} & \multicolumn{3}{|c|}{ Área de abrangência $\left(\mathrm{m}^{2}\right)$} & \multicolumn{3}{|c|}{$\begin{array}{c}\text { Área de } \\
\text { abrangência (\%) }\end{array}$} & \\
\hline Cenário Atual & 109.113 & 129.367 & 149.230 & 47.435 & 63.954 & 107.557 & 57 & 51 & 28 & 80 \\
\hline $\begin{array}{l}\text { Plano diretor e medidas não } \\
\text { estruturais }\end{array}$ & 139.492 & 155.120 & 169.340 & 103.521 & 114.710 & 135.621 & 26 & 26 & 20 & 87 \\
\hline Plano diretor & 149.250 & 163.584 & 180.458 & 110.129 & 129.414 & 146.862 & 26 & 21 & 19 & 90 \\
\hline Sem Plano Diretor & 156.314 & 169.522 & 185.680 & 121.410 & 138.836 & 154.584 & 22 & 18 & 17 & 93 \\
\hline $\begin{array}{l}\text { Plano diretor e medidas } \\
\text { estruturais e não estruturais }\end{array}$ & 123.870 & 141.309 & 154.579 & 66.484 & 102.695 & 116.803 & 46 & 27 & 24 & 87 \\
\hline $\begin{array}{l}\text { Plano diretor e medidas } \\
\text { estruturais }\end{array}$ & 129.371 & 145.297 & 156.783 & 99.577 & 109.564 & 126.083 & 23 & 24 & 19 & 90 \\
\hline
\end{tabular}


A diferença entre os métodos apresentada na tabela mostra um expressivo aumento na área da mancha da inundação, da ordem de 56\% para o cenário 1 (atual) com tempo de retorno de 25 anos(cenário de menor impacto dentre os comparados). Para o cenário 6 (sem plano diretor) com tempo de retorno de 100 anos (cenário com maior impacto dentre os comparados), o aumento da área da mancha de inundação foi da ordem de 16\%.

Os aumentos foram mais expressivos para o menor tempo de retorno ( $\mathrm{TR}=25$ anos), que se situou entre $57 \%$ e $22 \%$ para cenários sem reservatório e de $46 \%$ a $23 \%$ para os cenários com reservatórios. Já para o TR de 100 anos, situou-se entre 28\% e 17\% para os cenários sem reservatório e 24\% a 19\% para o cenário com reservatório.

O aumento na área de inundação em relação ao cenário que contém somente medidas estruturais (cenário 3) para o cenário com medidas estruturais em conjunto com as não estruturais (cenário 5) foi de 4\% para o blocos alternados, enquanto que no método de Huff este aumento foi de 66\% no TR de 25 anos. Nota-se que houve um aumento de 23\% da área de abrangência no cenário 5, enquanto que no cenário 3 esse aumento foi de $46 \%$ com relação ao método de distribuição da chuva (coluna "variação"), evidenciando a importância da integração das medidas não estruturais e estruturais nesta análise. Essa diferença mostra a grande sensibilidade do método com relação ao $\mathrm{CN}$, tendo em vista que o aumento do valor de CN de 87 para 90 pode influenciar nessa diferença.

Para ilustrar a diferença dos métodos de distribuição de chuva com relação à mancha de inundação simulada são apresentados nas Figuras 45 a 50, o cenário atual com tempos de retorno de 25, 50 e 100 anos pelos métodos de distribuição temporal blocos alternados e Huff $1^{\circ}$ quartil. As manchas para os demais cenários são apresentados no Apêndice A. 


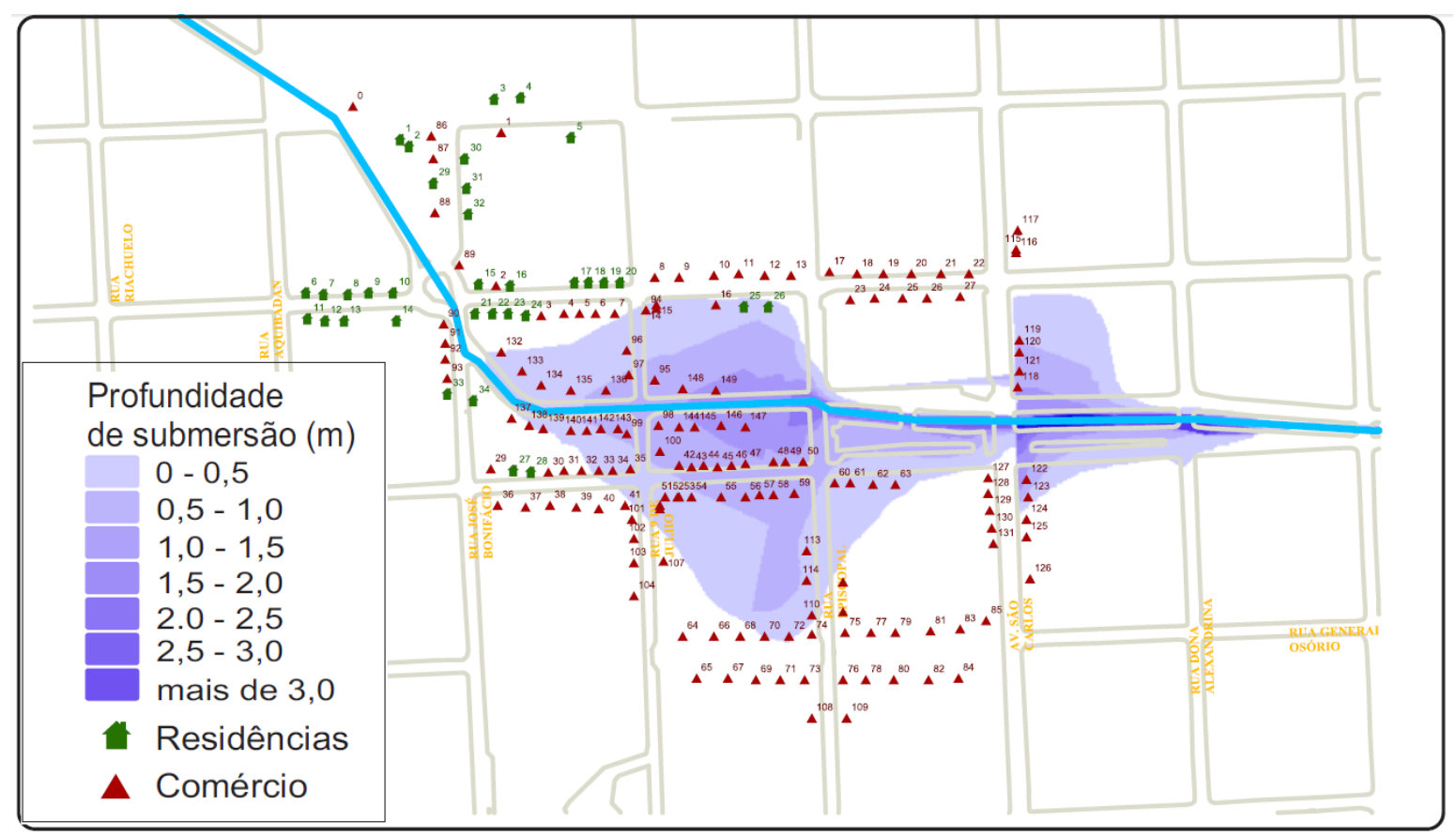

Figura 45 - Mancha de inundação para o tempo de retorno de 25 anos no cenário atual pelo método de distribuição temporal das chuvas Huff $1^{\circ}$ quartil

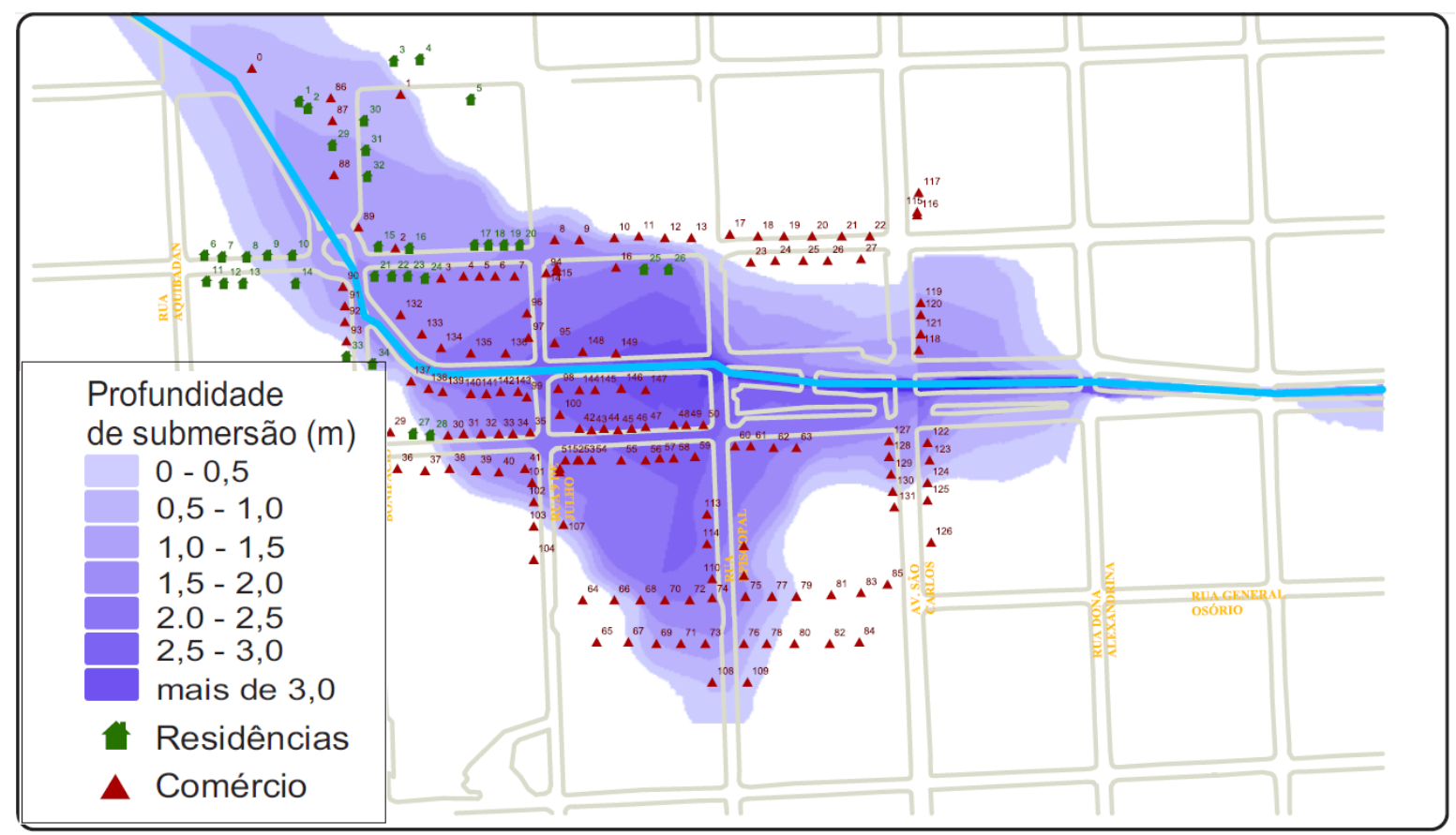

Figura 46 - Mancha de inundação para o tempo de retorno de 25 anos no cenário atual pelo método de distribuição temporal das chuvas blocos alternados 


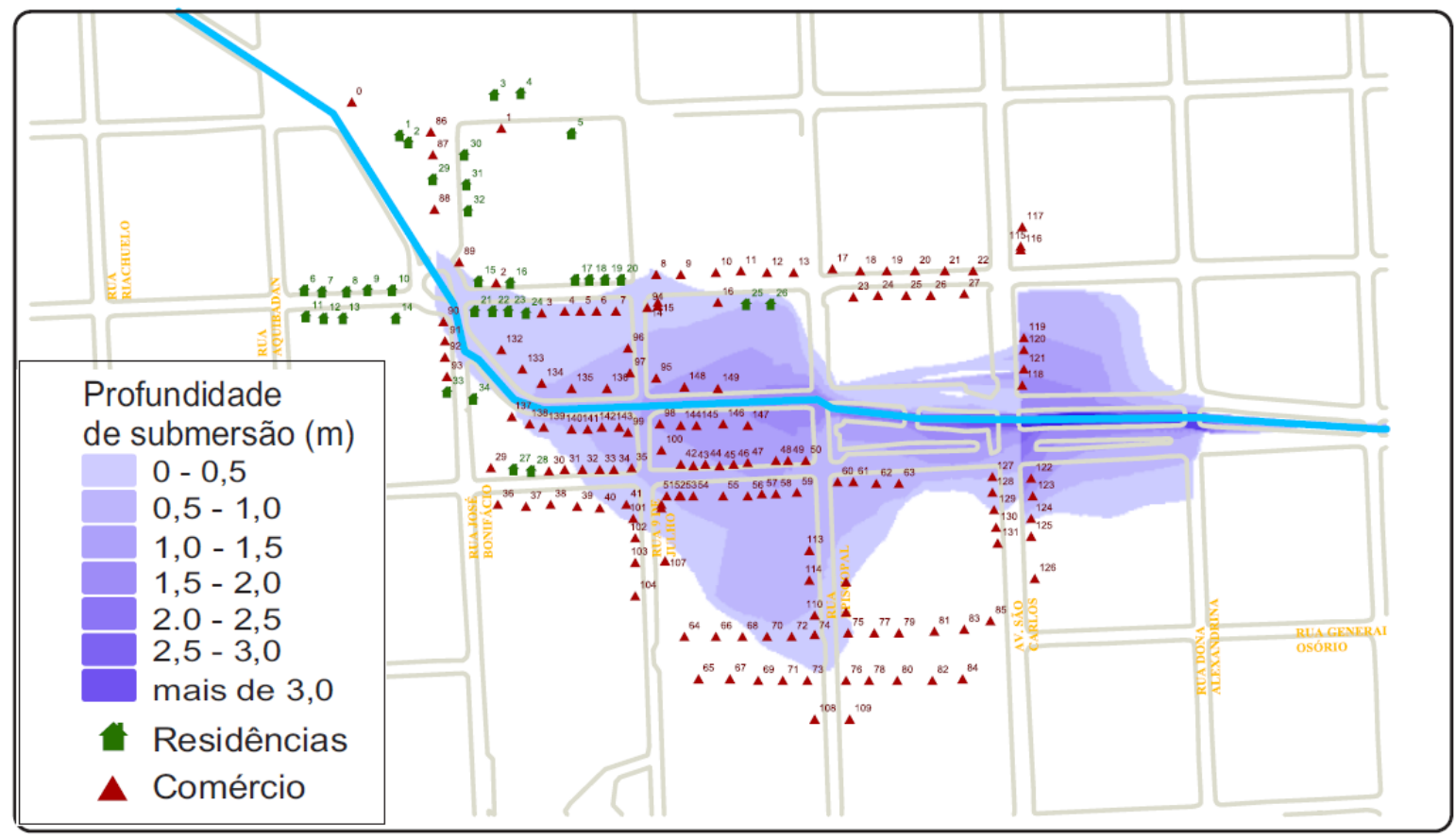

Figura 47 - Mancha de inundação para o tempo de retorno de 50 anos no cenário atual pelo método de distribuição temporal das chuvas Huff 10 quartil

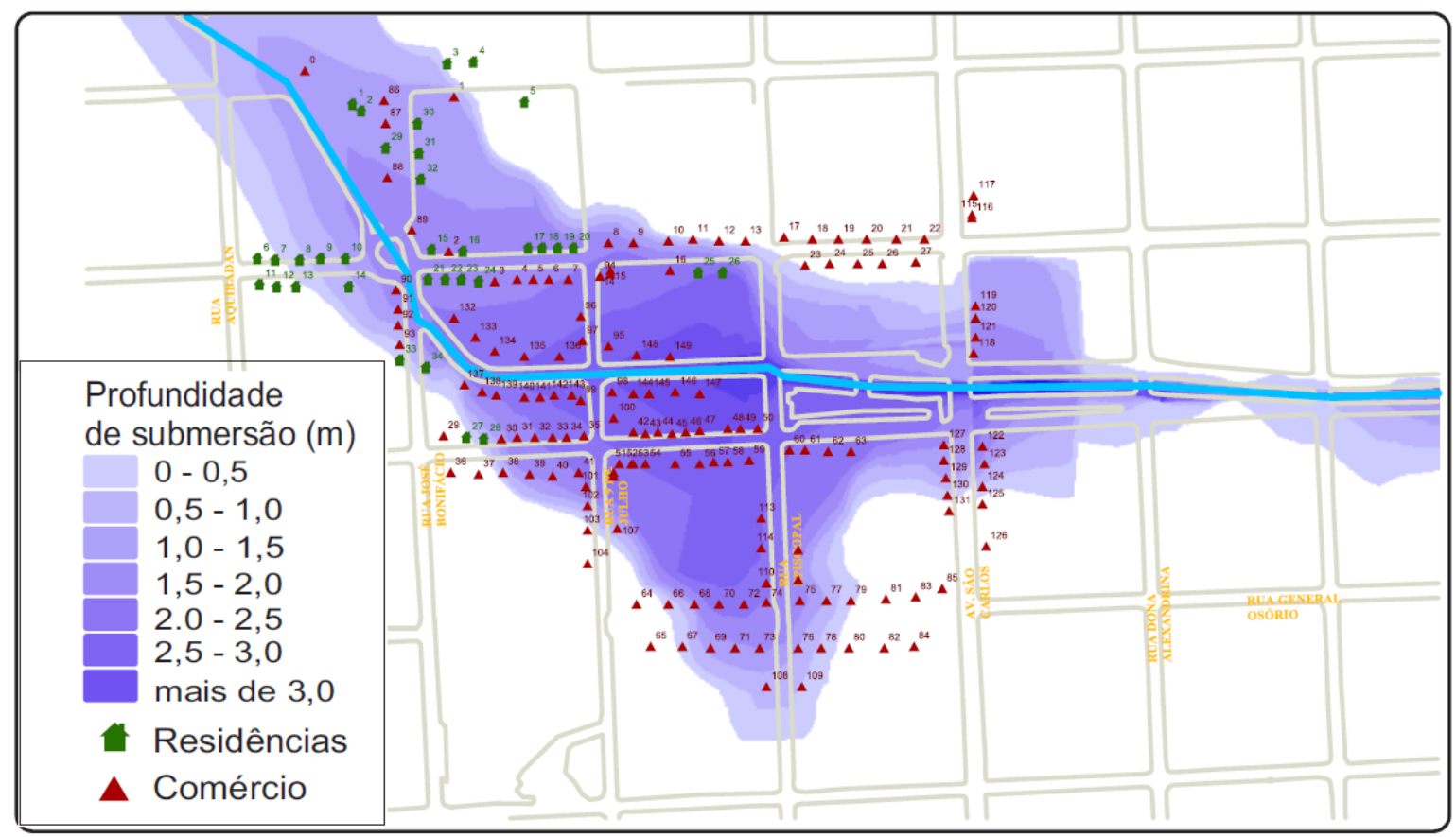

Figura 48 - Mancha de inundação para o tempo de retorno de 50 anos no cenário atual pelo método de distribuição temporal das chuvas blocos alternados 


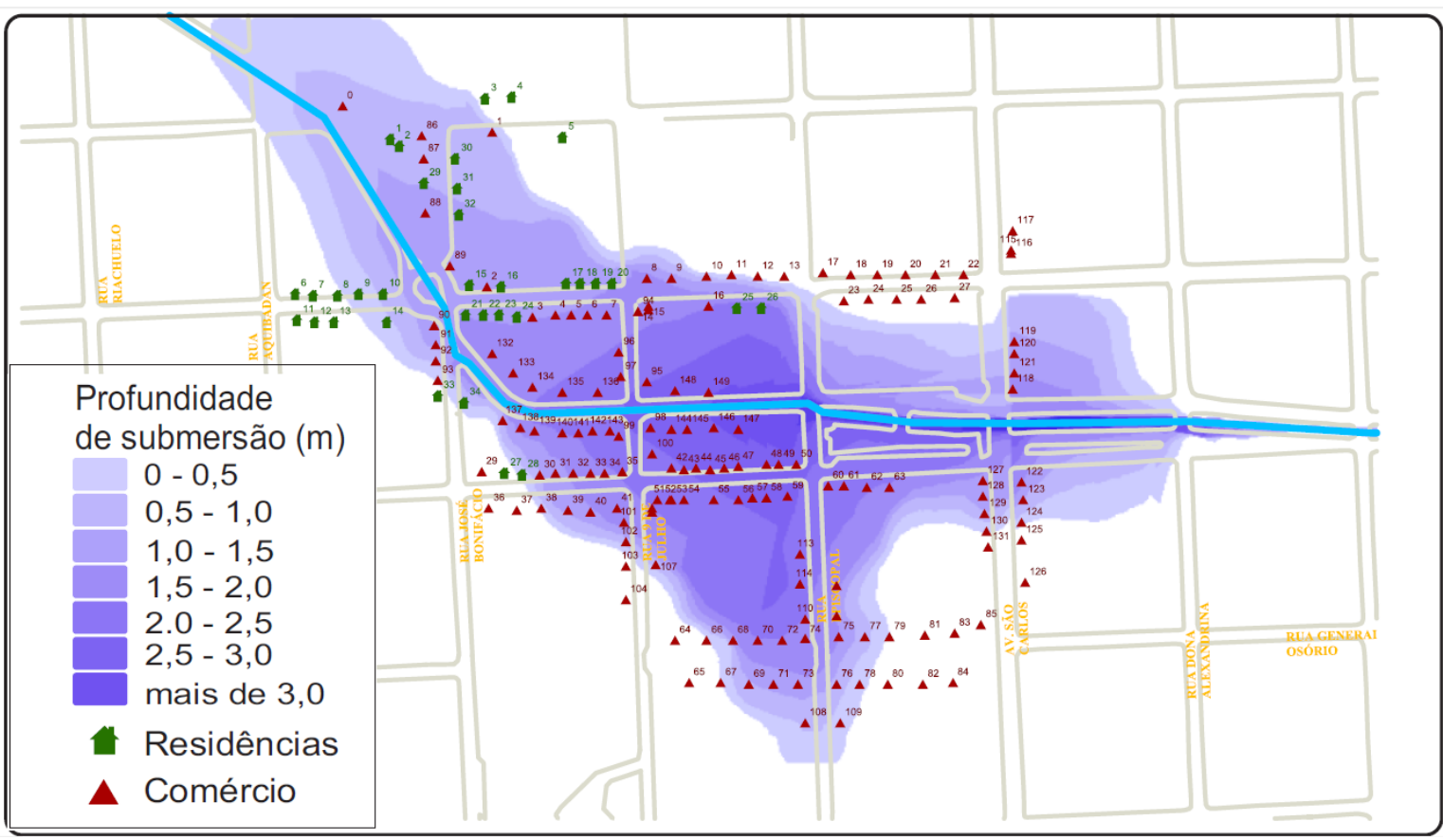

Figura 49 - Mancha de inundação para o tempo de retorno de 100 anos no cenário atual pelo método de distribuição temporal das chuvas Huff $1^{\circ}$ quartil

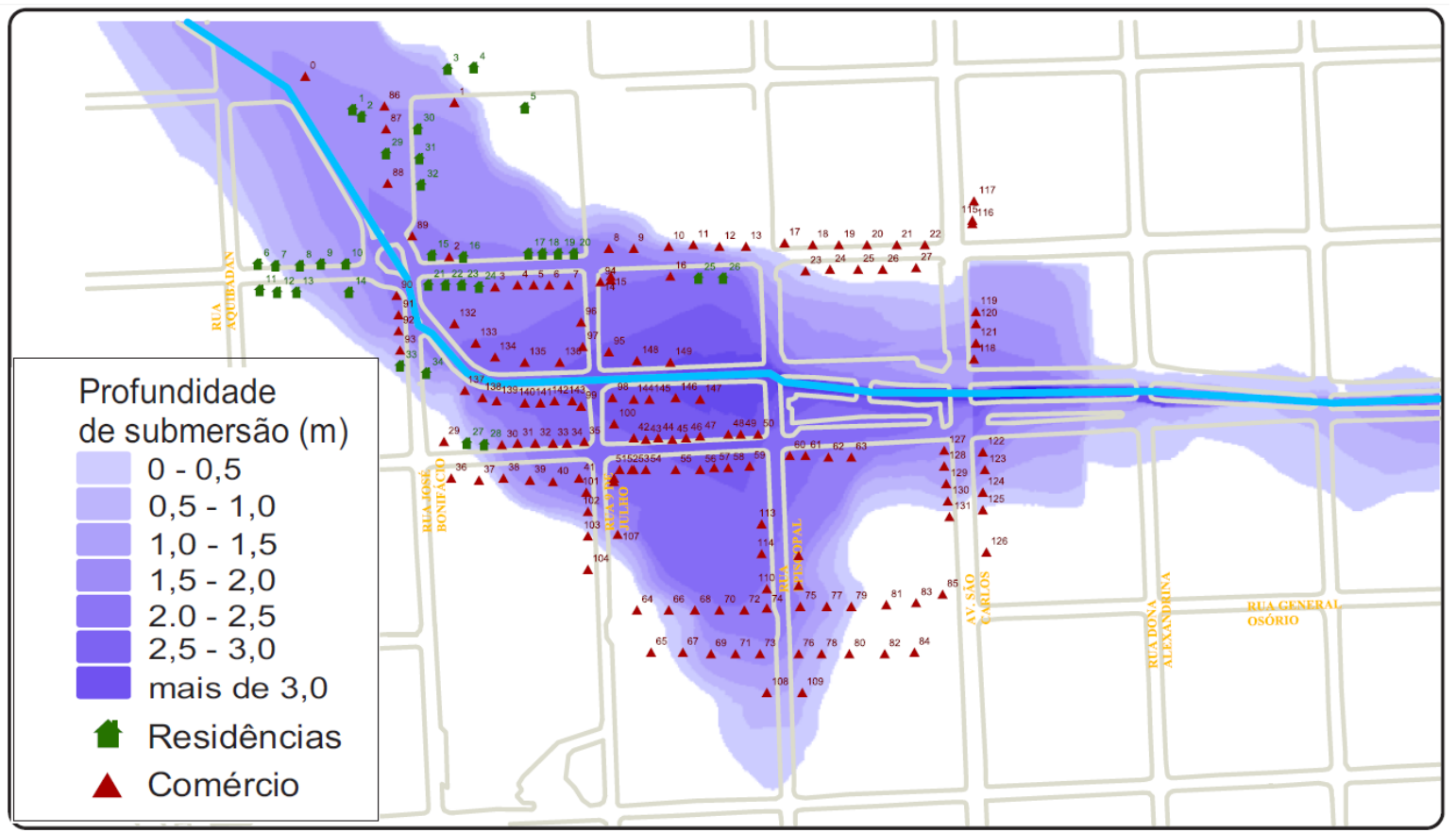

Figura 50 - Mancha de inundação para o tempo de retorno de 100 anos no cenário atual pelo método de distribuição temporal das chuvas blocos alternados

É possível perceber pelas figuras que cenários de maior impacto hidrológico tendem a ter menores variações de áreas de abrangência em comparação as distribuições temporais das chuvas abordadas nos métodos simulados neste trabalho. Novamente, esses valores são variáveis da distribuição da chuva no tempo, que, no modelo, apresentam grandes diferenças no volume de escoamento gerado. 


\subsection{Resultados econômicos}

Para representar os prejuízos das empresas contidas na mancha de inundação, foram utilizados gráficos boxplot, como descrito no item 4.8. Nesses gráficos, o eixo das ordenadas primário (eixo y à esquerda) representa as variáveis estatísticas referentes ao prejuízo individual dos imóveis presentes na mancha de inundação, enquanto o eixo das ordenadas secundário (eixo y à direita) representa os valores acumulados dos prejuízos para cada evento, representado pela variável "prejuízo acumulado”.

Num primeiro momento, foram inseridas todas as empresas na elaboração do gráfico, como apresentado na Figura 30. Além disso, foram utilizados gráficos para representar o somatório dos prejuízos por evento e o número de empresas contidas na mancha de inundação, para as categorias de imóveis residenciais e comerciais.

\subsubsection{Blocos alternados}

\subsubsection{Comércio}

Foram elaborados gráficos Boxplot para mostrar as variáveis estatísticasdo valor do prejuízo ao conteúdo dos imóveis comerciais de acordo com cada cenário abordado. A variável y primária (valor do prejuízo ao conteúdo dos imóveis) representa as variações individuais dos imóveis comerciais presentes na mancha de inundação para determinado evento hidrológico e cenário de uso e coupação do solo. A variável y secundária (valor acumulado do prejuízo aos imóveis) representa o valor total do prejuízo dos imóveis contidos na mancha de inundação em um cada evento/cenário de ocupação. No eixo x encontram-se os cenários modelados neste trabalho. Os gráficos são apresentados nas Figuras 51 a 53 . Nesses gráficos, Q1 e Q3 referem-se respectivamente ao primeiro e terceiro quartil. O gráfico com a variável prejuízo acumulado para todos cenários é apresentada na Figura 54. 


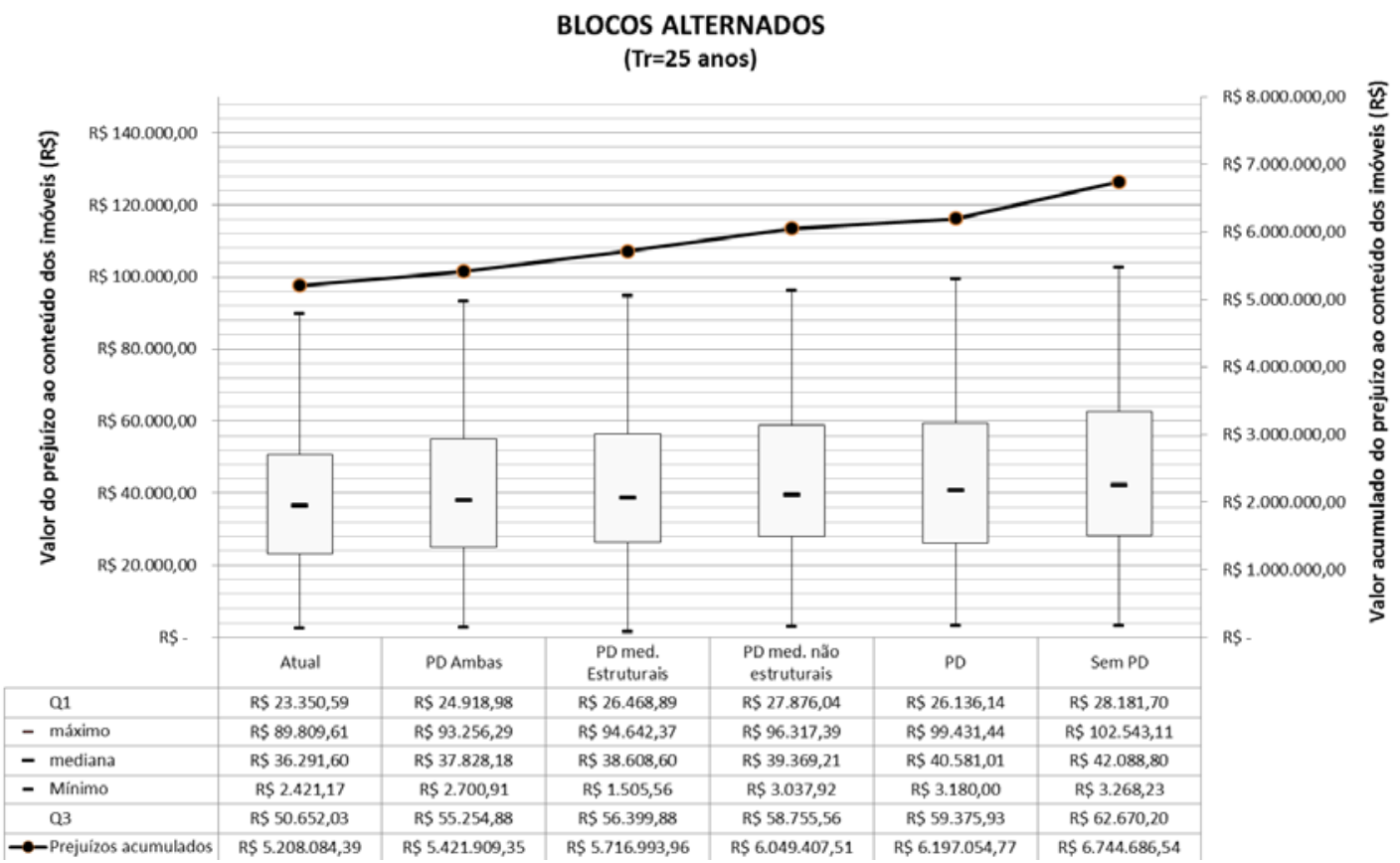

Figura 51 - Valor do prejuízo ao conteúdo dos imóveis comerciais pelo método dos blocos alternados e tempo de retorno de 25 anos

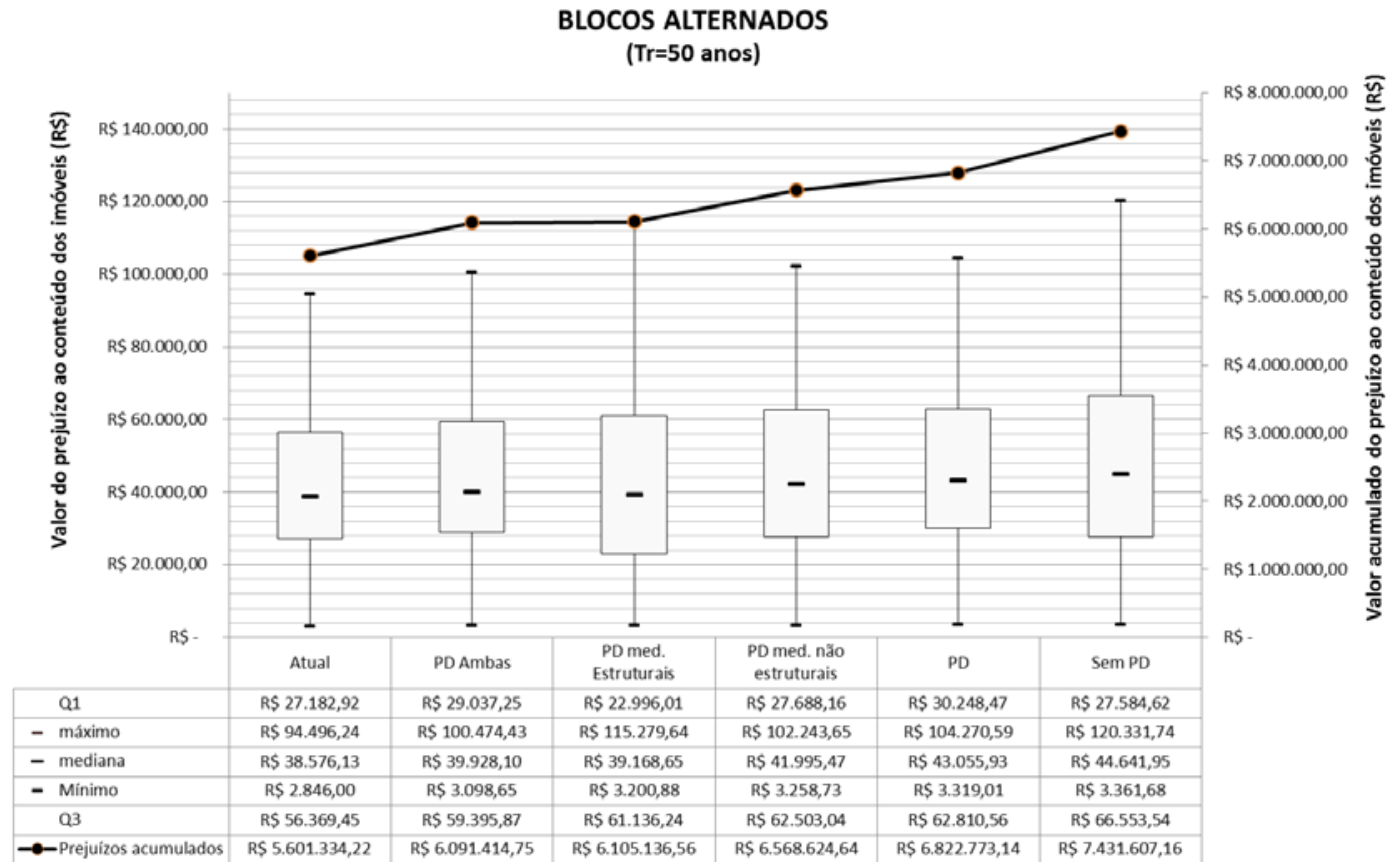

Figura 52 - Valor do prejuízo ao conteúdo dos imóveis comerciais pelo método dos blocos alternados e tempo de retorno de 50 anos 


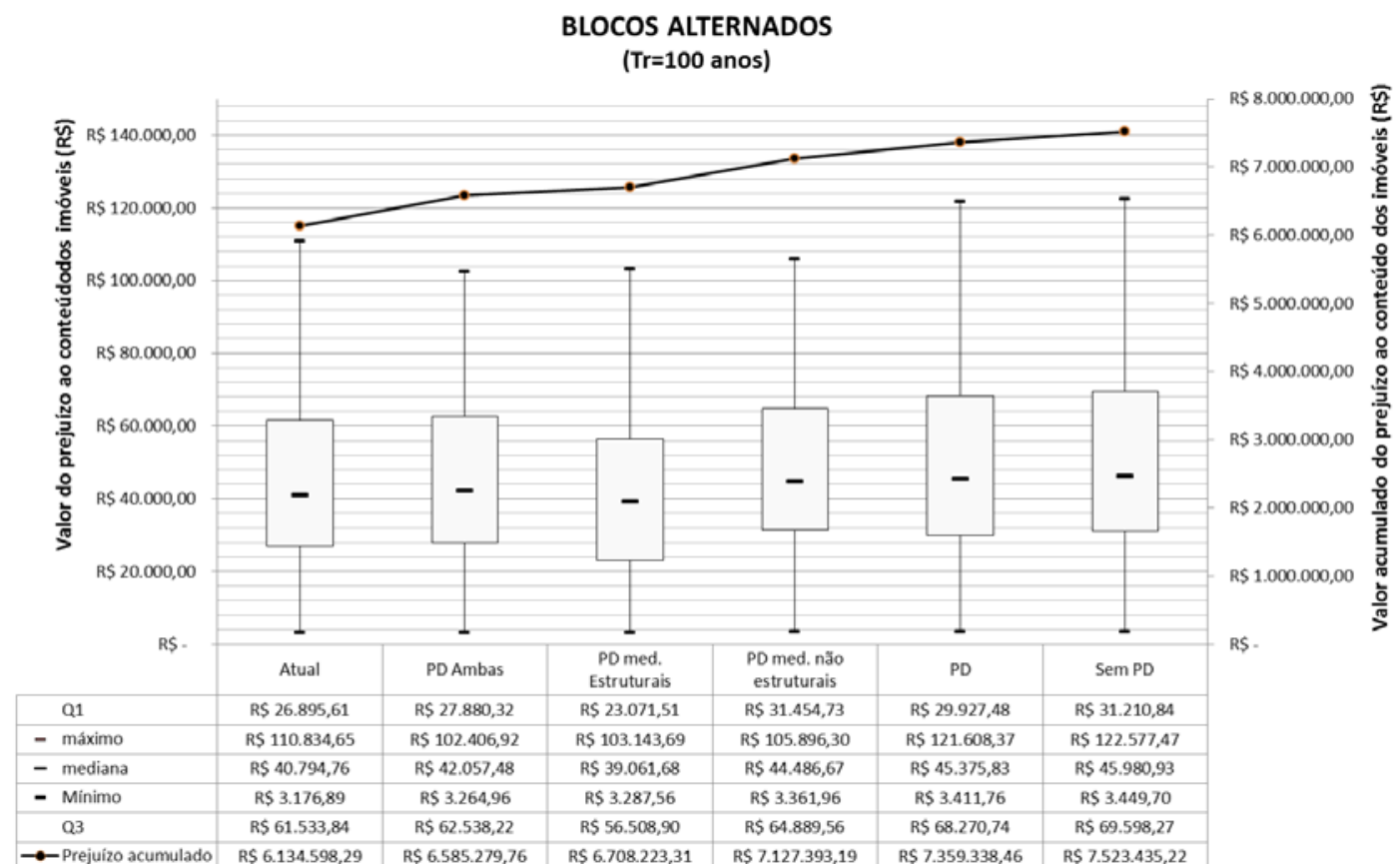

Figura 53 - Valor do prejuízo ao conteúdo dos imóveis comerciais pelo método dos blocos alternados e tempo de retorno de 100 anos

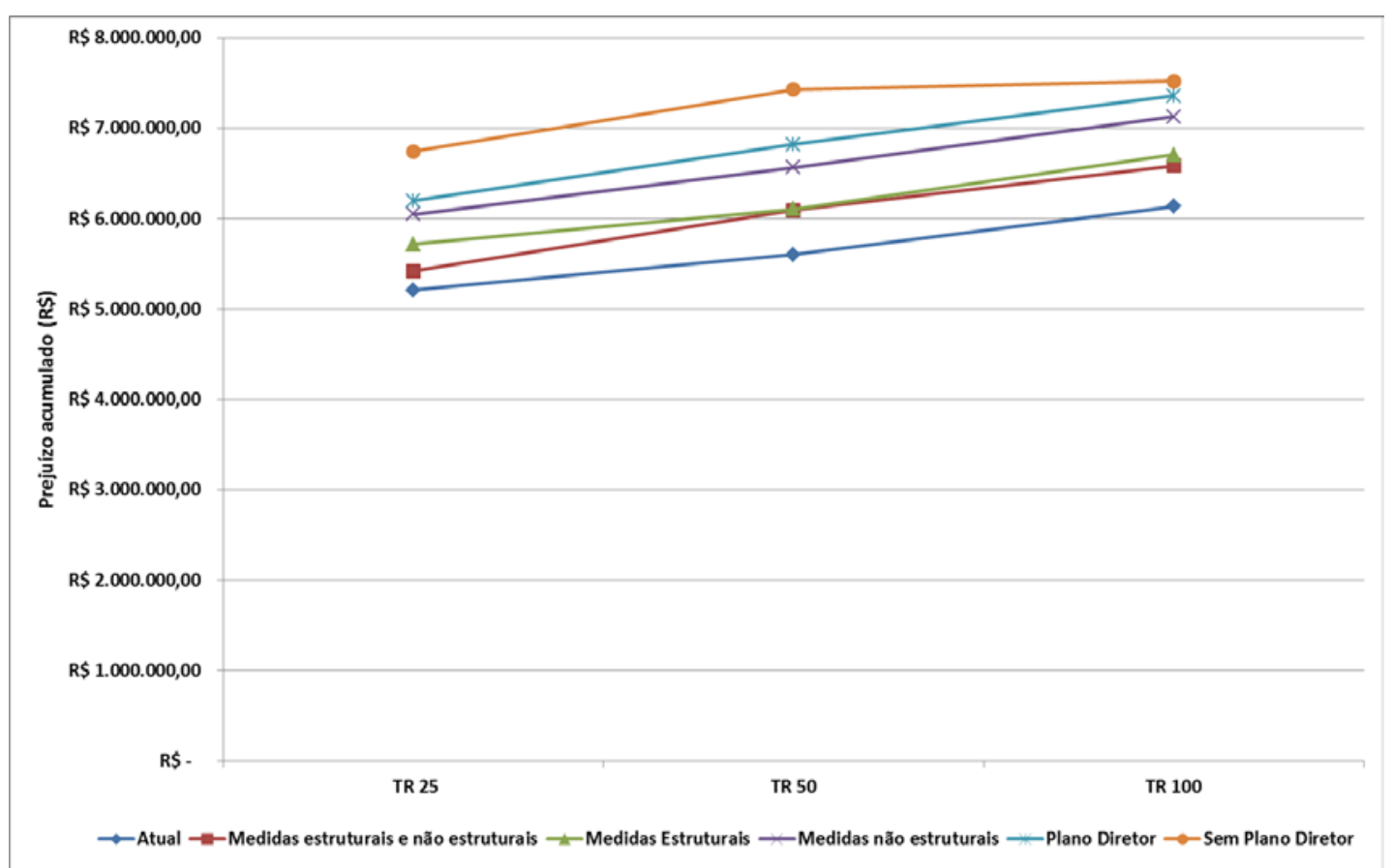

Figura 54 - Prejuízo acumulado dos imóveis comerciais pelo método de distribuição temporal blocos alternados

Observa-se uma linearidade dos prejuízos acumulados ocorridos em todos os eventos, com uma variação de 30,8\% entre os prejuízos acumulados no cenário de menor impacto (atual; TR=25 anos) para o cenário de maior impacto (Sem plano diretor; TR=100 anos). A mesma linearidade se sucedeu com os parâmetros estatísticos, que demonstraram a baixa variabilidade encontrada entre os valores do prejuízo individual das empresas. Isto ocorreu devido às elevadas alturas de submersão que se encontram os imóveis, como pode 
observado na Figura 46 para tempo de retorno de 25 anos no cenário atual, que mostra que a maior parte das empresas já se encontravam contidas na mancha de inundação. Assim percebe-se também que os cenários têm pouca influencia no valor do prejuízo para este método de distribuição temporal.

\subsubsection{Residências}

As variações estatísticas ocorridas entre os diferentes cenários para as residências sob o método de distribuição dos blocos alternados e de acordo com os tempos de retorno das chuvas são apresentadas nas Figuras 55 a 57.

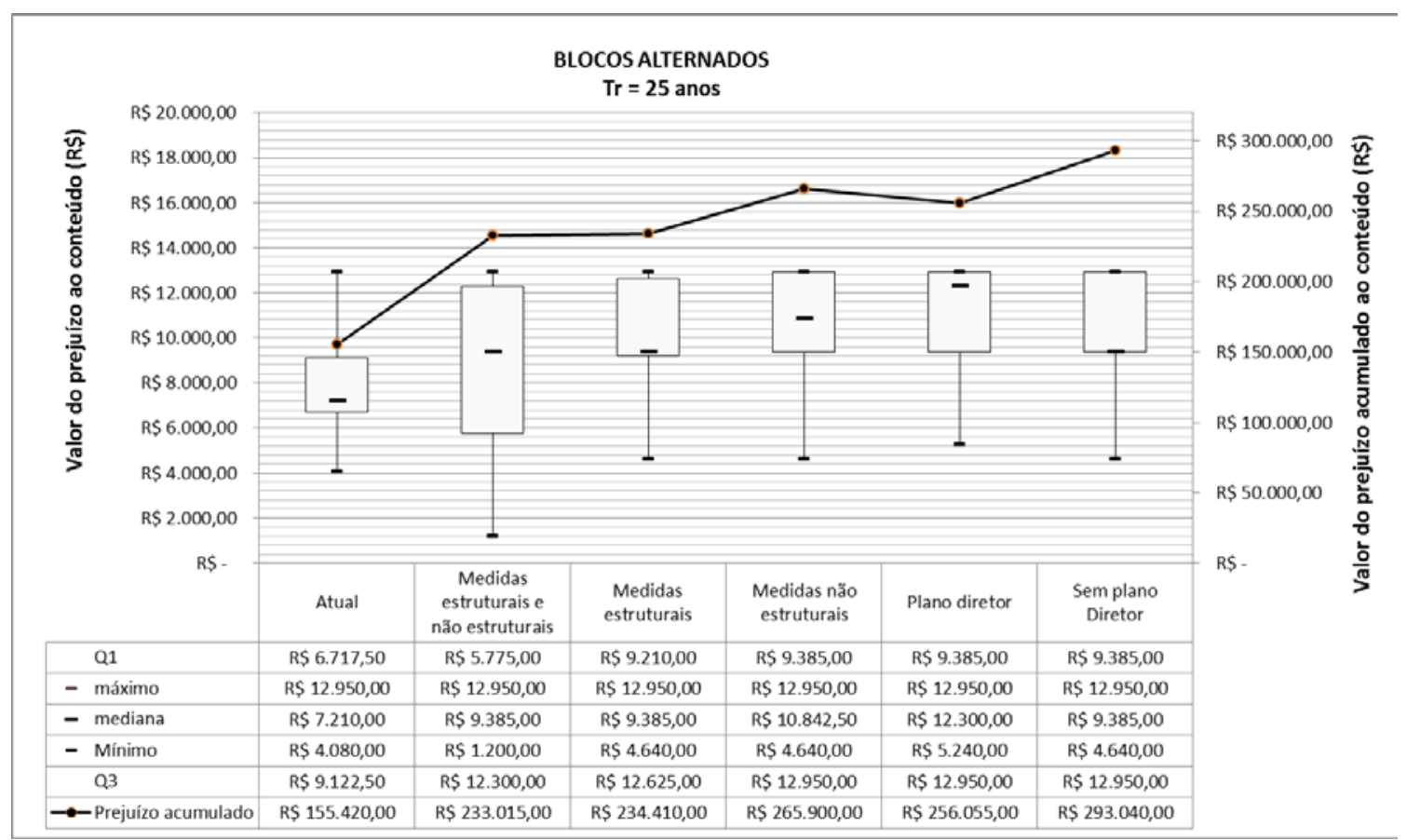

Figura 55 - Valor do prejuízo ao conteúdo dos imóveis residenciais pelo método dos blocos alternados e tempo de retorno de 25 anos 


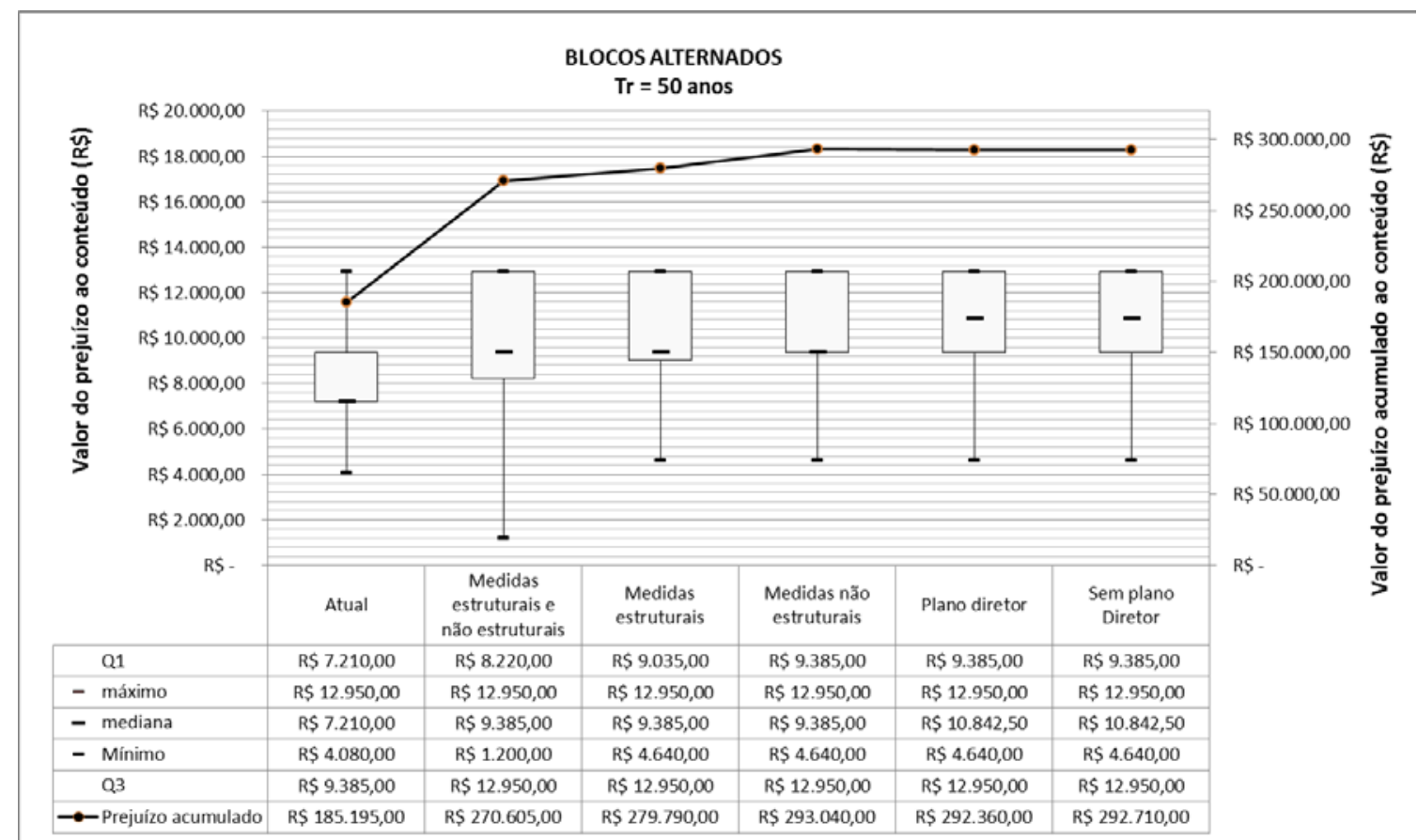

Figura 56 - Valor do prejuízo ao conteúdo dos imóveis residenciais pelo método dos blocos alternados e tempo de retorno de 50 anos

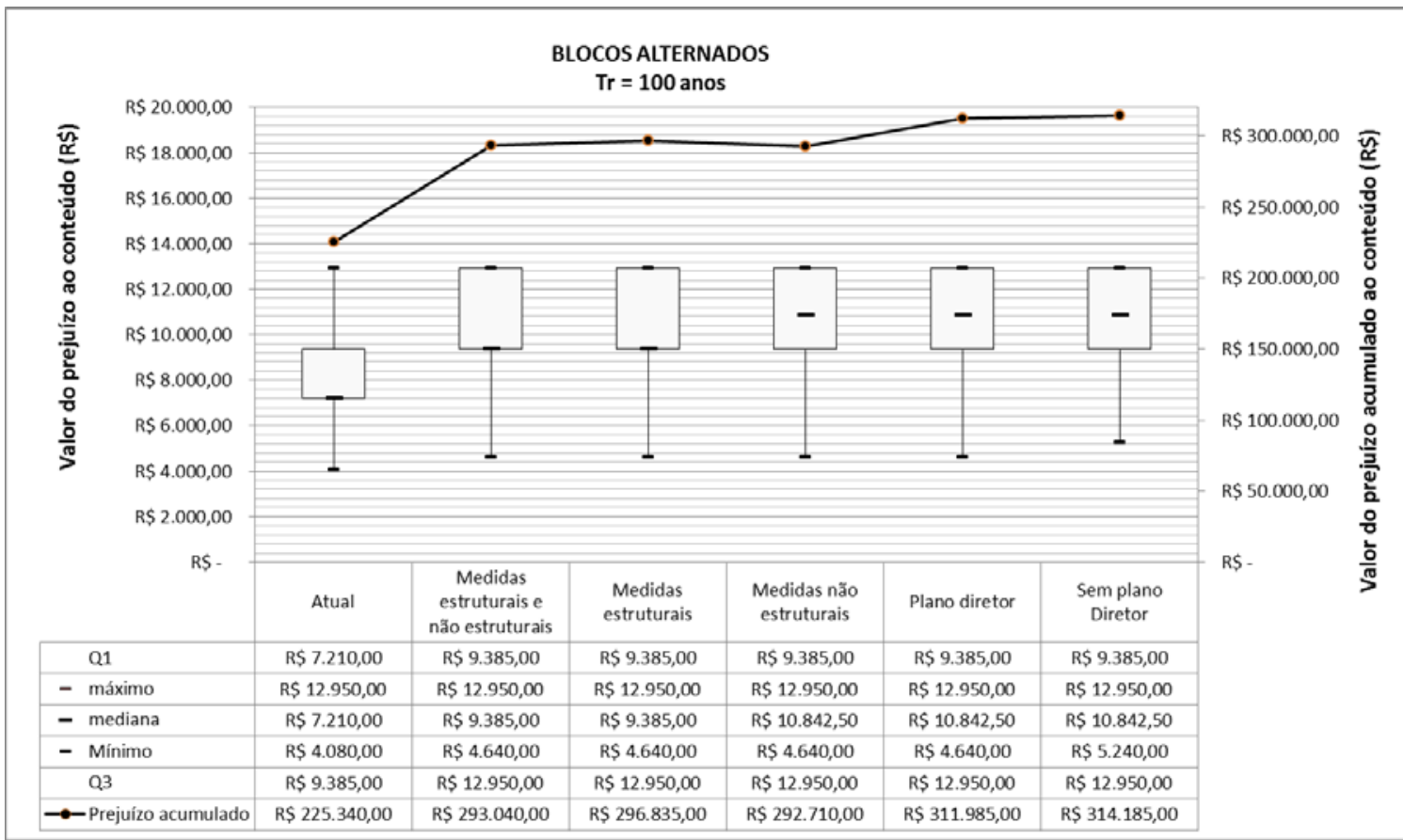

Figura 57 - Valor do prejuízo ao conteúdo dos imóveis residenciais pelo método dos blocos alternados e tempo de retorno de 100 anos

Em meio à análise dos valores do prejuízo a que se encontram as residências, podemos notar que a maior parte destas encontra-se na faixa de prejuízo entre $\mathrm{R} \$ 7.000,00 \mathrm{a}$ $\mathrm{R}$ \$ 12.000,00, acumulando prejuízos que variam de $\mathrm{R} \$ 155.420,00$ a $\mathrm{R}$ \$ 314.185,00. No cenário 6 (sem plano diretor), são encontradas as menores variações relacionadas ao prejuízo do conteúdo dos imóveis entre o tempo de retorno de 25 e 100 anos (6,7\%), tendo em vista as 
elevadas alturas de submersão em que se encontram as residências. Por outro lado, no cenário 1 (atual), encontram-se as maiores variações quanto ao prejuízo (31,0\%). O prejuízo acumulado ao conteúdo das residências utilizando o método de distribuição de chuvas de blocos alternados é apresentado na Figura 58.

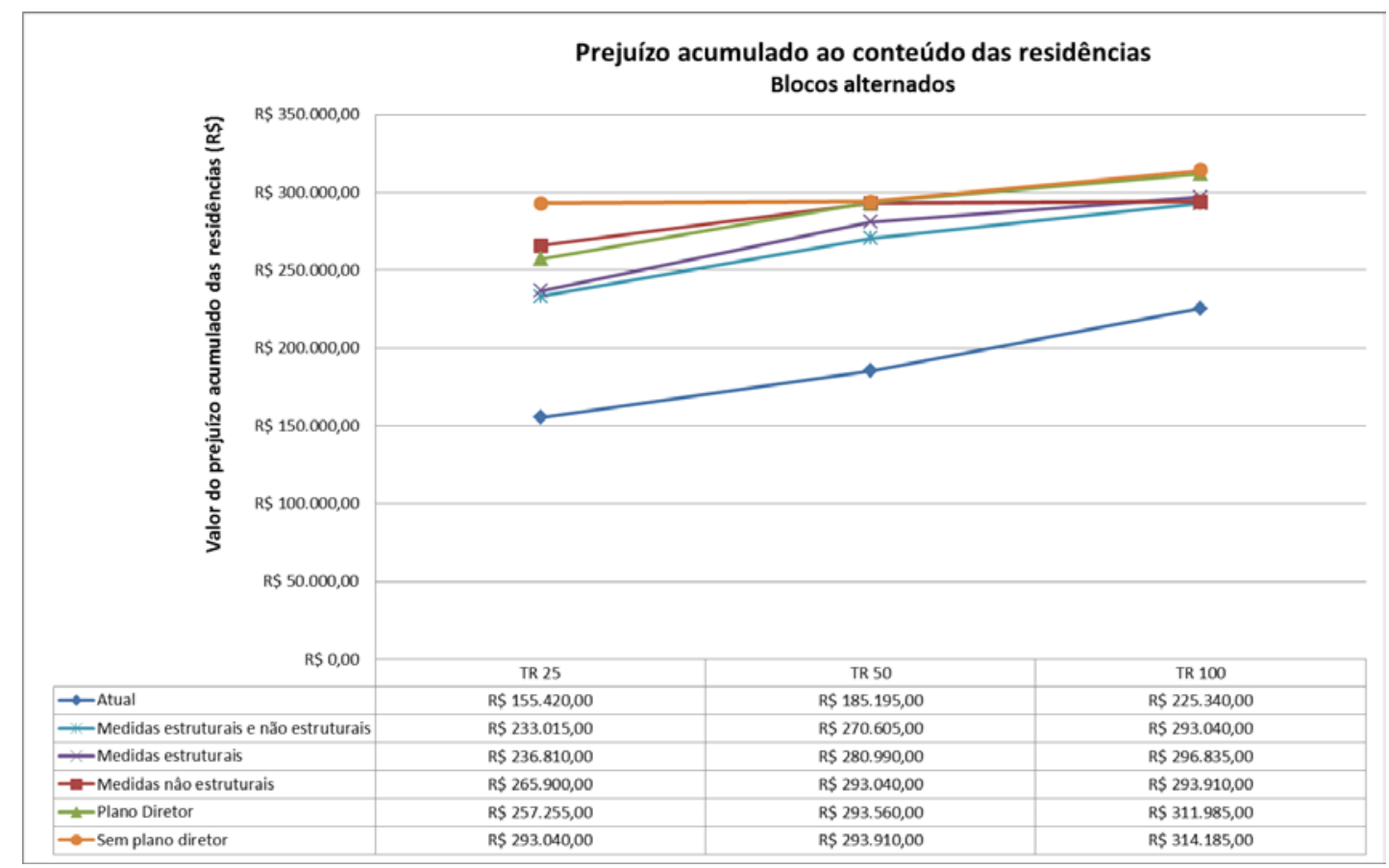

Figura 58 - Prejuízo acumulado das residências - método blocos alternados

Pela simulação realizada para as residências pelo método dos blocos alternados, apresentados na Figura 58, percebe-se que no cenário atual o prejuízo acumulado das residências é expressivamente menor quando comparado aos outros cenários futuros. Neste aspecto, as técnicas compensatórias simuladas para os cenários futuros não apresentaram redução significativa dos prejuízos ao conteúdo dos imóveis, já que nos cenários futuros, os cenários com medidas compensatórias (cenários 2 a 5) aproximaram-se do cenário “sem plano diretor”, no qual não houve qualquer intervenção do poder público (cenário 6).

Cabe notar que as residências encontram-se concentradas a direita na parte superior da mancha de inundação, fato que gerou alturas de inundação diferentes daquelas obtidas pelo comércio. 


\subsubsection{Huff $1^{\circ}$ quartil}

\subsubsection{Comércio}

As variáveis estatísticasdo valor do prejuízo ao conteúdo dos imóveis comerciais de acordo com cada cenário abordado e utilizando-se do método do Huff $1^{\circ}$ quartil são apresentadas na Figuras 59 a 61. Os gráficos apresentados nas figuras relacionam os prejuízos de acordo com o tempo de retorno e o cenário a que estão expostos.

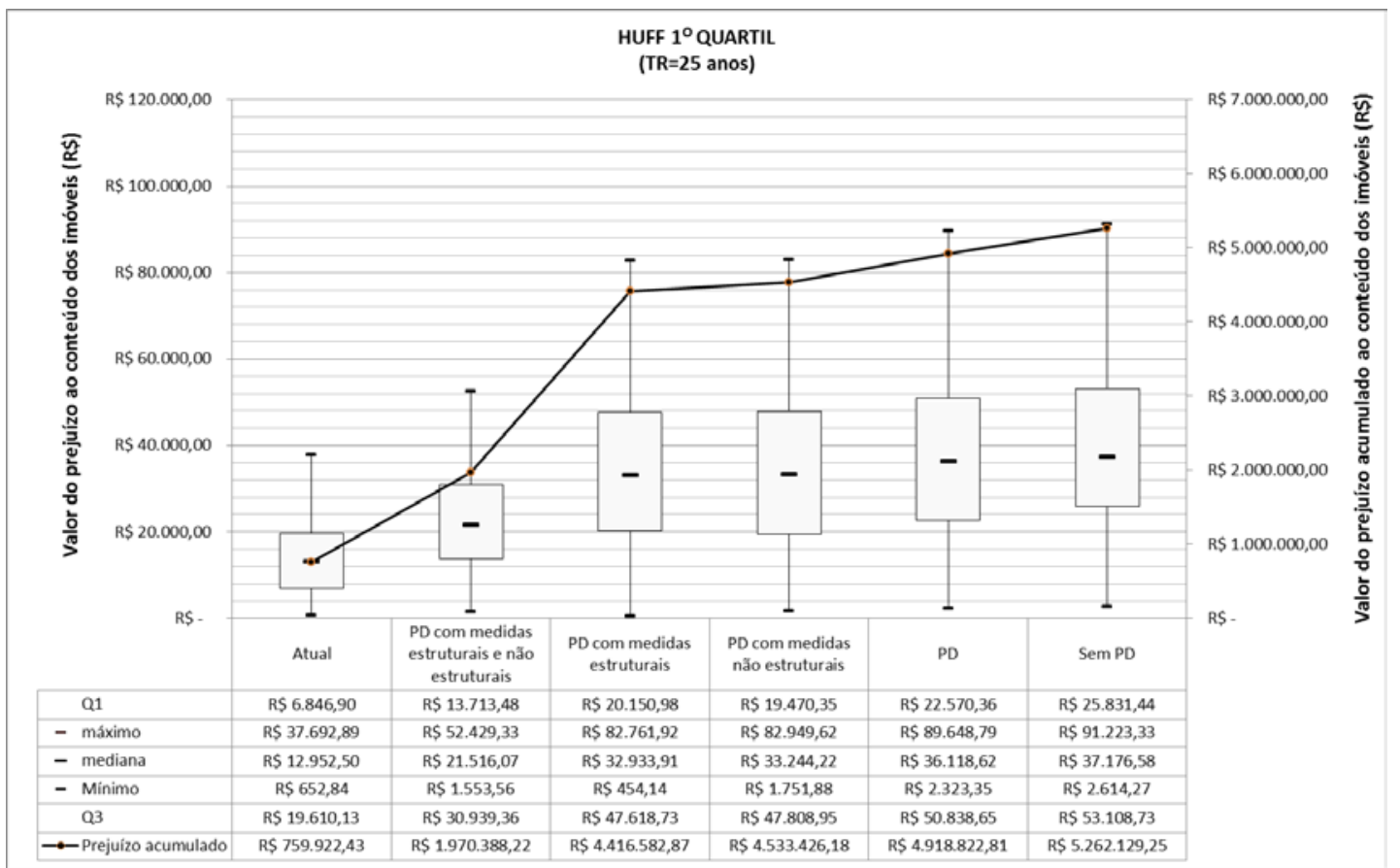

Figura 59 - Valor do prejuízo ao conteúdo dos imóveis comerciais sob o método de Huff $1^{\circ}$ quartil para o tempo de retorno de 25 anos 


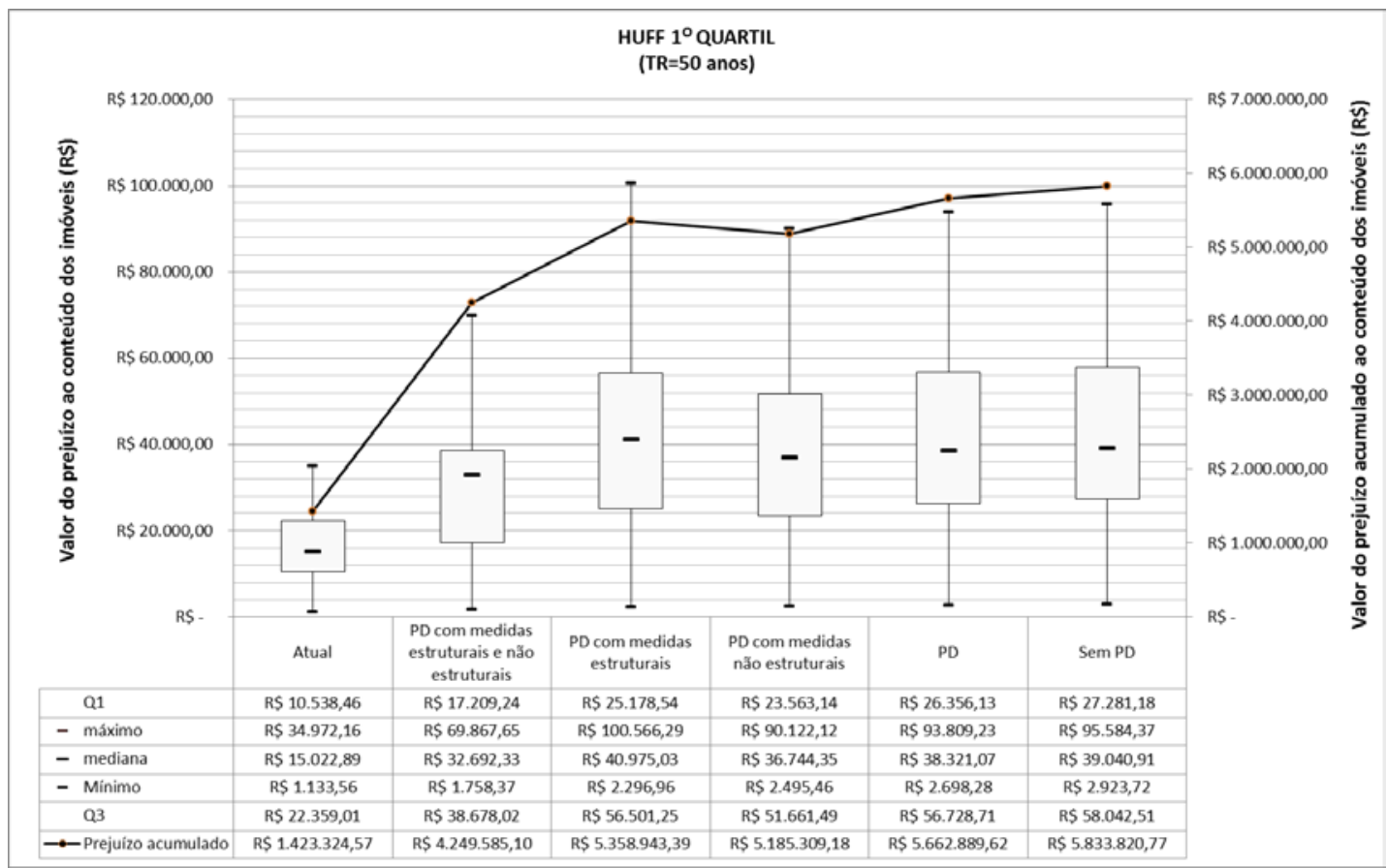

Figura 60 - Valor do prejuízo ao conteúdo dos imóveis comerciais sob o método de Huff $1^{\circ}$ quartil para o tempo de retorno de 50 anos

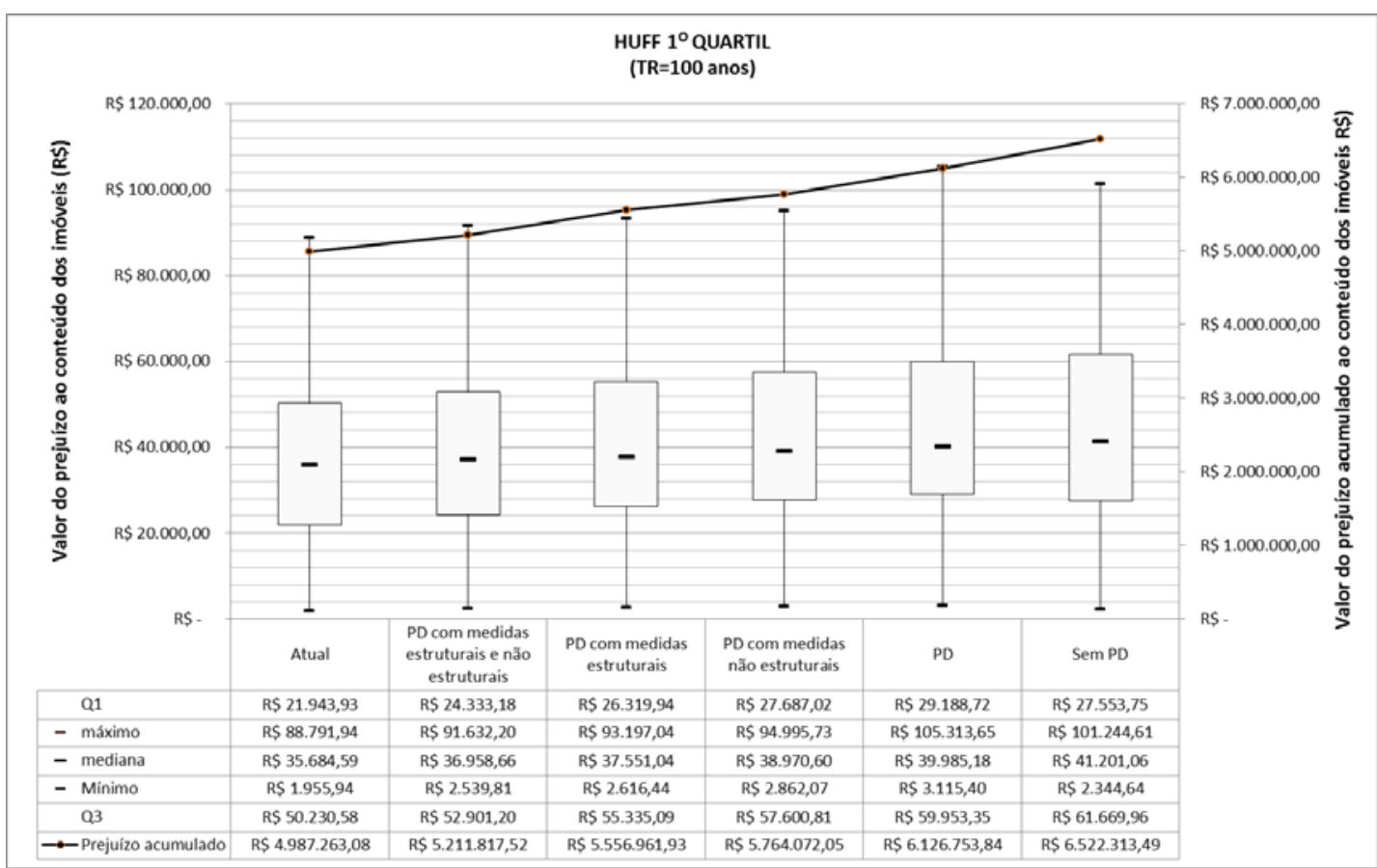

Figura 61 - Valor do prejuízo ao conteúdo dos imóveis comerciais sob o método de Huff $1^{\circ}$ quartil para o tempo de retorno de 100 anos

No tempo de retorno de 25 anos, é possível observar a baixa eficácia que as medidas compensatórias proporcionam de forma isolada na simulação dos cenários futuros (cenários 2 a 4), que se reflete no alto prejuízo que ocorre nestes cenários. Porém, quando aplicadas em 
conjunto (Cenário "PD com medidas estruturais e não estruturais”), reduzem o impacto de forma significativa.

A simulação com o cenário que contém medidas estruturais e não estruturais atinge valores elevados com tempo de retorno de 50 anos, cujo prejuízo se aproxima aos dos cenários contendo apenas medidas estruturais para o tempo de retorno de 25 anos, o que mostra a eficiência das medidas não estruturais no controle das inundações.

O tempo de retorno de 100 anos mostra que os prejuízos tornam-se máximos nesses eventos hidrológicos, com variações pouco significativas entre os cenários. Esse fato sugere a adoção do tempo de retorno 100 anos como evento de máximo prejuízo, devido à linearidade dos prejuízos em relação aos cenários adotados.

Os valores do prejuízo acumulado pelo método de distribuição das chuvas de Huff $1^{\circ}$ quartil para empresas contidas na mancha de inundação são apresentados na Figura 62. O gráfico resume os impactos econômicos dos eventos de inundação simulados nesta distribuição temporal da precipitação.

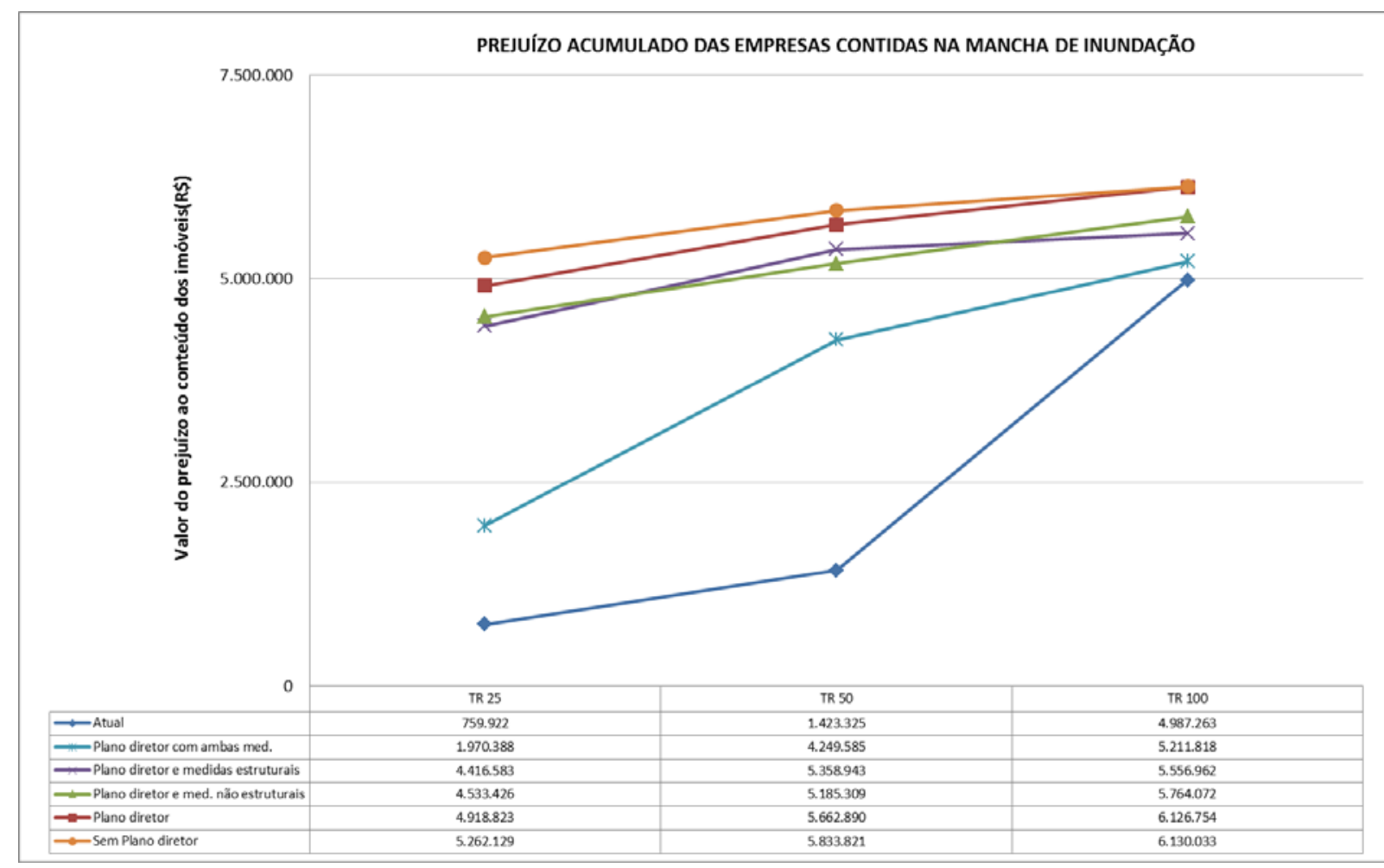

Figura 62 - Prejuízo acumulado das empresas contidas na mancha de inundação utilizando o método de Huff $1^{\circ}$ quartil

Os valores apresentados pela Figura 62 mostram que apenas para o cenário atual e para o cenário com plano diretor e medidas estruturais e não estruturais (TR 25 anos), o prejuízo não atingiu valores próximos ao máximo. 
Dessa forma, a simulação mostra que a adoção de medidas estruturais ou a adoção de medidas de disciplinamento do uso e ocupação do solo (medidas não estruturais) de maneira isolada não serão suficientes para mitigar os efeitos da ocupação de zonas das sub-bacias não urbanizadas localizadas no Córrego do Gregório.

\subsubsection{Residências}

As variáveis estatísticas para as residências contidas na mancha de inundação pelo método de Huff $1^{\circ}$ quartil com tempo de retorno de 25, 50 e 100 anos são mostradas nas Figuras 63 a 65. Os dados são apresentados em gráficos boxplot.

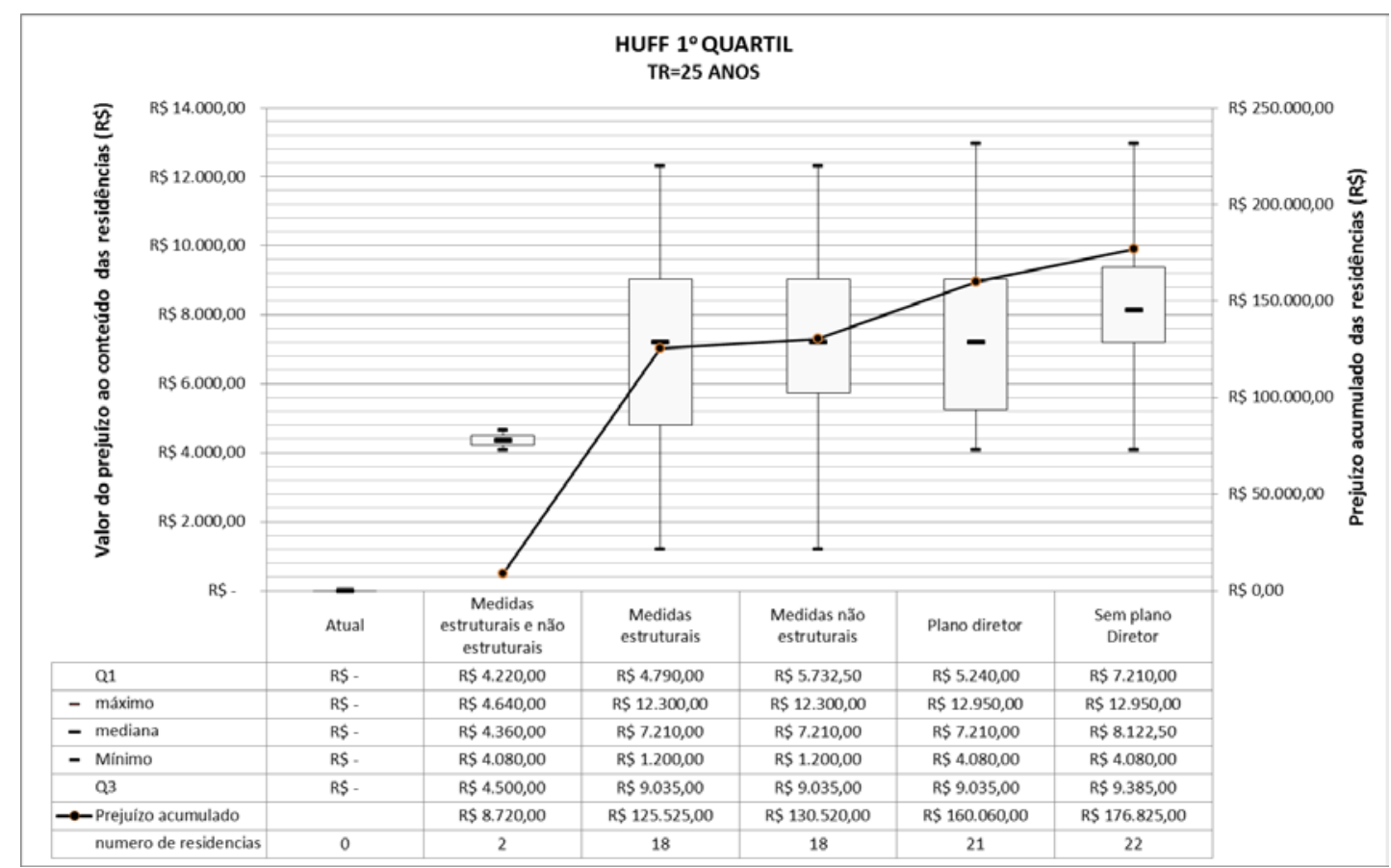

Figura 63 - Valor do prejuízo ao conteúdo dos imóveis residenciais sob o método de Huff $1^{\circ}$ quartil para o tempo de retorno de 25 anos 


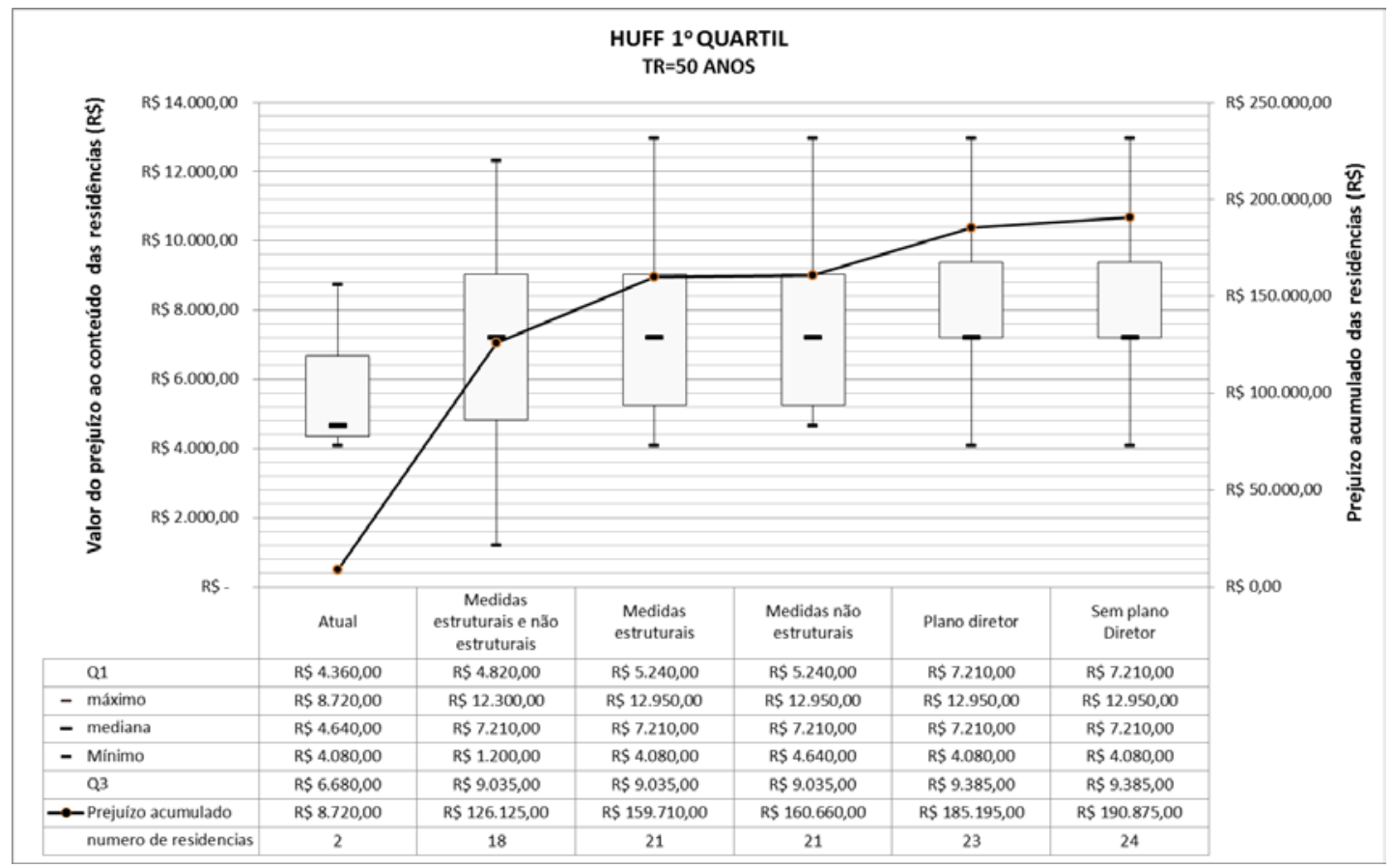

Figura 64 - Valor do prejuízo ao conteúdo dos imóveis residenciais sob o método de Huff $1^{\circ}$ quartil para o tempo de retorno de 50 anos

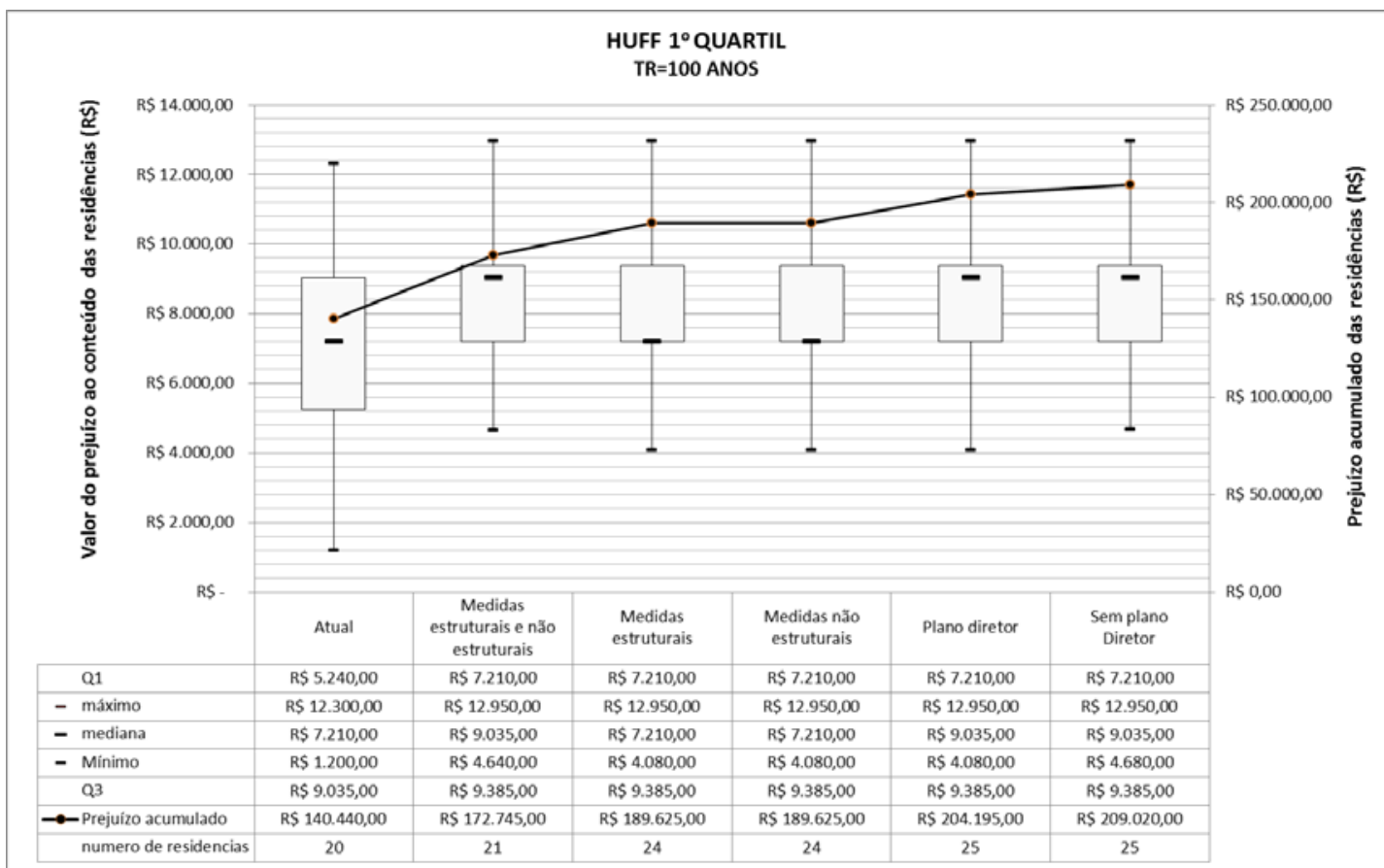

Figura 65 - Valor do prejuízo ao conteúdo dos imóveis residenciais sob o método de Huff $1^{\circ}$ quartil para o tempo de retorno de 100 anos

Através das figuras é possível perceber que o prejuízo das residências pelo método de Huff inicia-se no tempo de retorno de 50 anos, quando duas residências inserem-se na mancha de inundação. Porém, para o tempo de retorno de 100 anos, 20 residências já fazem parte da 
mancha de inundação e o valor das variáveis individuais e do prejuízo acumulado torna-se próximo daqueles obtidos para os outros cenários.

Para o cenário com as medidas estruturais e não estruturais com tempo de retorno de 25 anos, obtém-se resultado semelhante àquele obtido para o cenário atual com tempo de retorno de 50 anos, com 2 empresas contidas na mancha de inundação.

Para os cenários com medidas estruturais (cenário 3) e o cenário com medidas não estruturais (cenário 4), o prejuízo foi praticamente o mesmo. Dessa forma, pode-se concluir pelas simulações que obras hidráulicas (medidas estruturais) podem ter o mesmo efeito do adequado disciplinamento do uso e ocupação do solo (medidas não estruturais).

Para os demais cenários, obtiveram-se valores próximos ao prejuízo máximo já com tempo de retorno de 25 anos.

\subsection{Análise da profundidade de submersão e relação com o Índice de ameaça da inundação ao conteúdo (IA $\left.\mathrm{M}_{2}\right)$}

Para mostrar as profundidades de submersão a que as empresas estão sujeitas e uma estimativa do prejuízo decorrente desta situação, foram elaborados gráficos a fim de mostrar estatisticamente estas variações.

O eixo das abscissas primário (eixo y à esquerda) refere-se à altura de submersão a que estão sujeitas as empresas e são apresentadas graficamente pelo boxplot, enquanto que o eixo das abscissas secundário (eixo y à direita) define o percentual de prejuízo a que está submetido o imóvel baseado no Índice de ameaça da inundação ao conteúdo - $I A_{M 2}$, proposto por Cançado (2009) representado pela linha superior. São descritos os resultados obtidos pelo método de Huff $1^{\circ}$ quartil categorizado por tempo de retorno e por cenário para cada evento analisado.

As profundidades de submersão a que estão submetidas às empresas para o método dos blocos alternados são apresentadas nas Figuras 66 a 68. Nas Figuras 69 a 71 são apresentados os mesmos parâmetros pelo método de Huff $1^{\circ}$ quartil. A Figura 72 é uma comparação entre o Índice $\mathrm{IA}_{\mathrm{M} 2}$ e o prejuízo acumulado das empresas. Na Figura 73 são apresentados gráficos comparativos entre os dois métodos para os parâmetros máximo, mediana, mínimo, quartil Q1 e quartil Q3. 


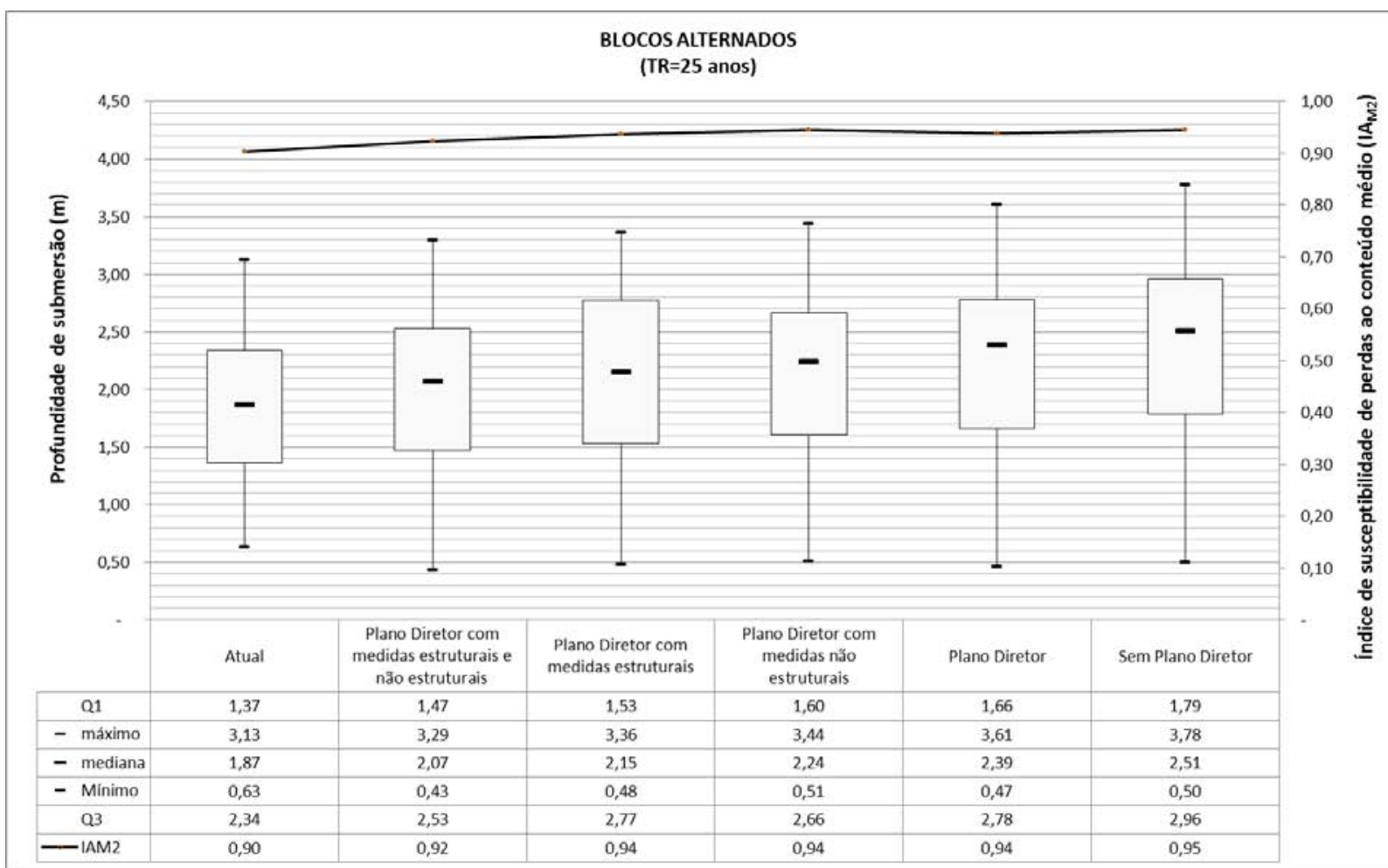

Figura 66 - Profundidade de submersão e Índice de ameaça da inundação ao conteúdo - (IA $\left.\mathrm{M} 2_{2}\right)$ para um evento hidrológico com tempo de retorno de 25 anos pelo método blocos alternados

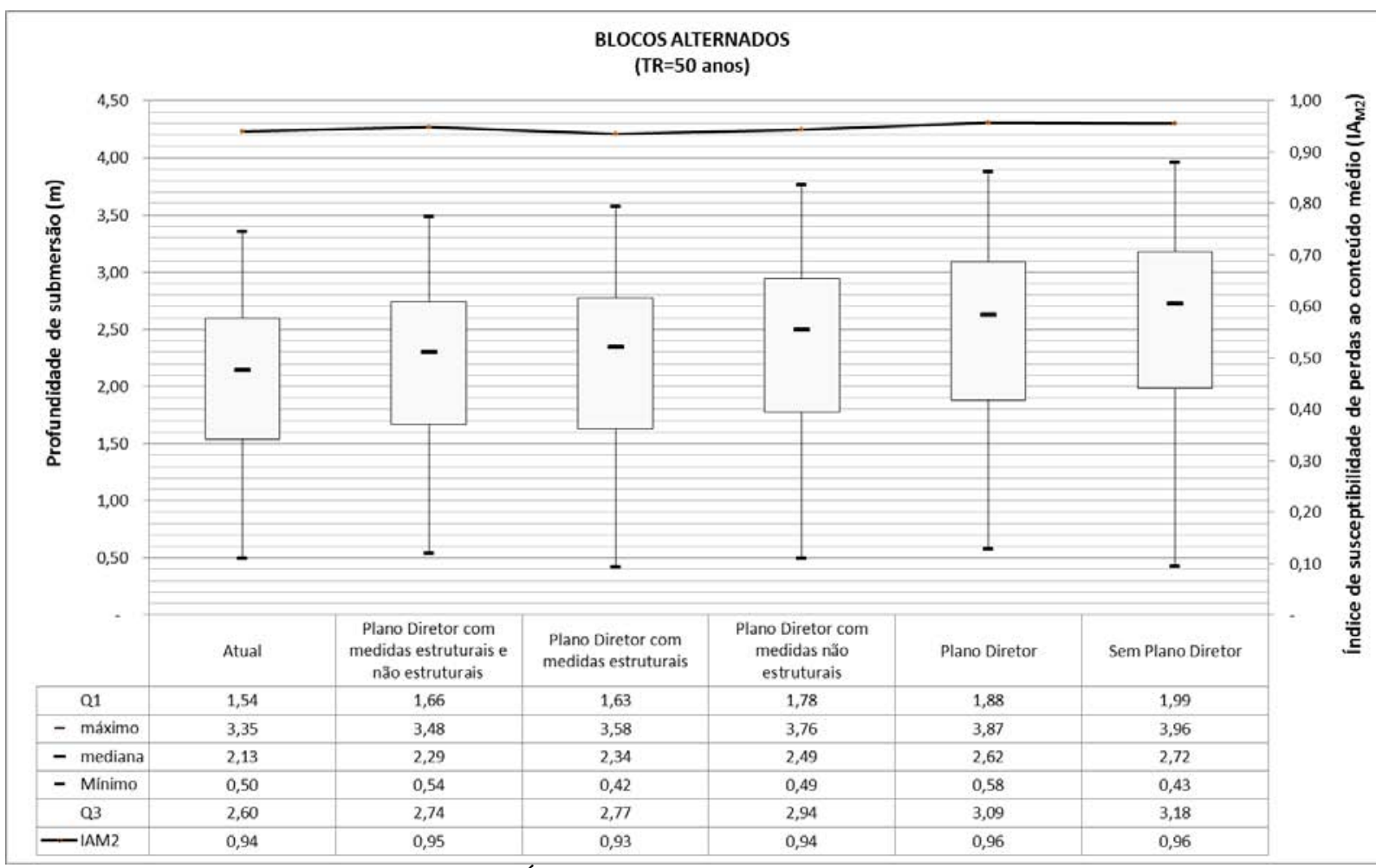

Figura 67 - Profundidade de submersão e Índice de ameaça da inundação ao conteúdo - (IA $\left.\mathrm{I}_{\mathrm{M} 2}\right)$ para um evento hidrológico com tempo de retorno de 50 anos pelo método blocos alternados 


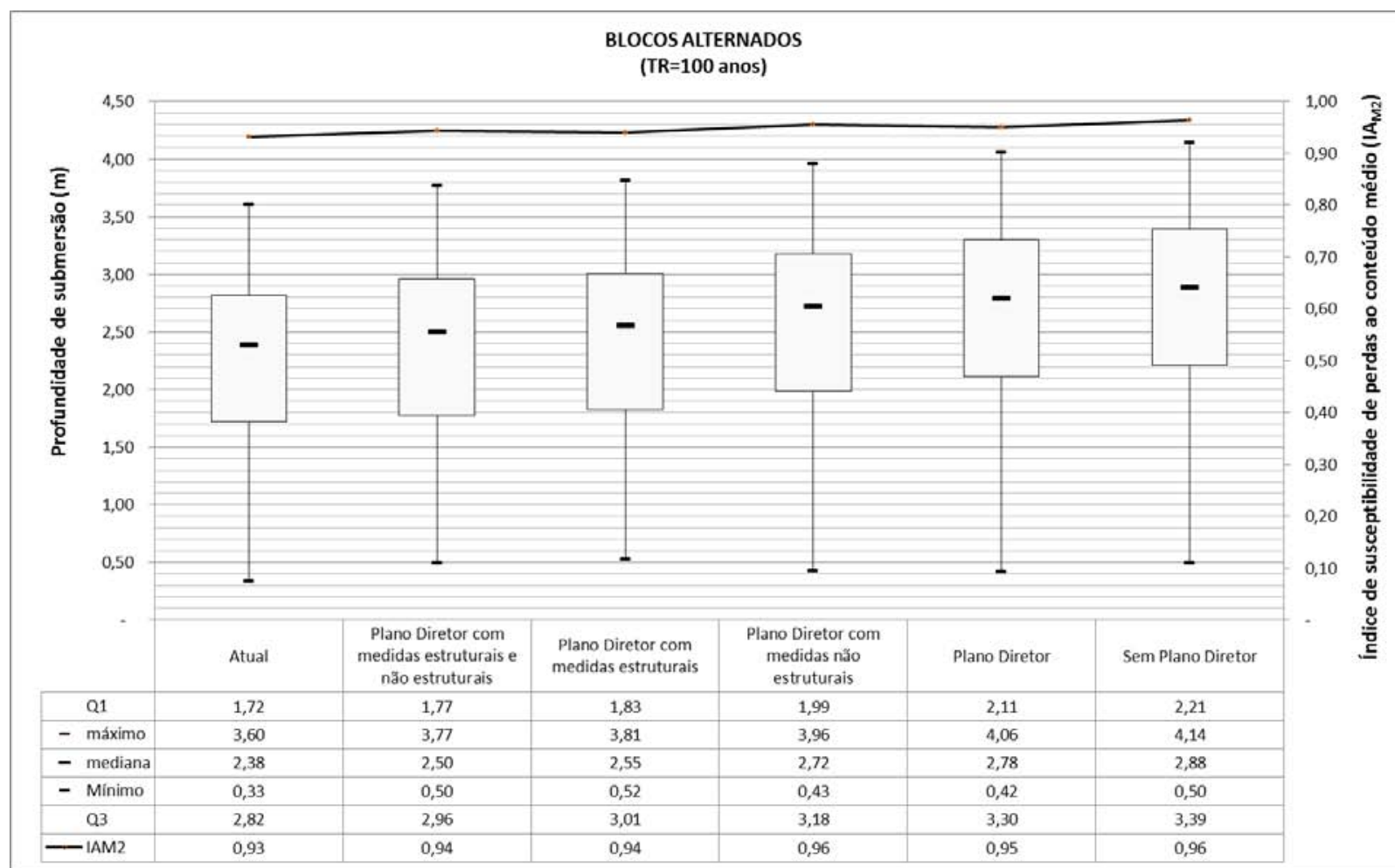

Figura 68 - Profundidade de submersão e Índice de ameaça da inundação ao conteúdo - (IA $\left.\mathrm{M}_{2}\right)$ para um evento hidrológico com tempo de retorno de 100 anos pelo método blocos alternados

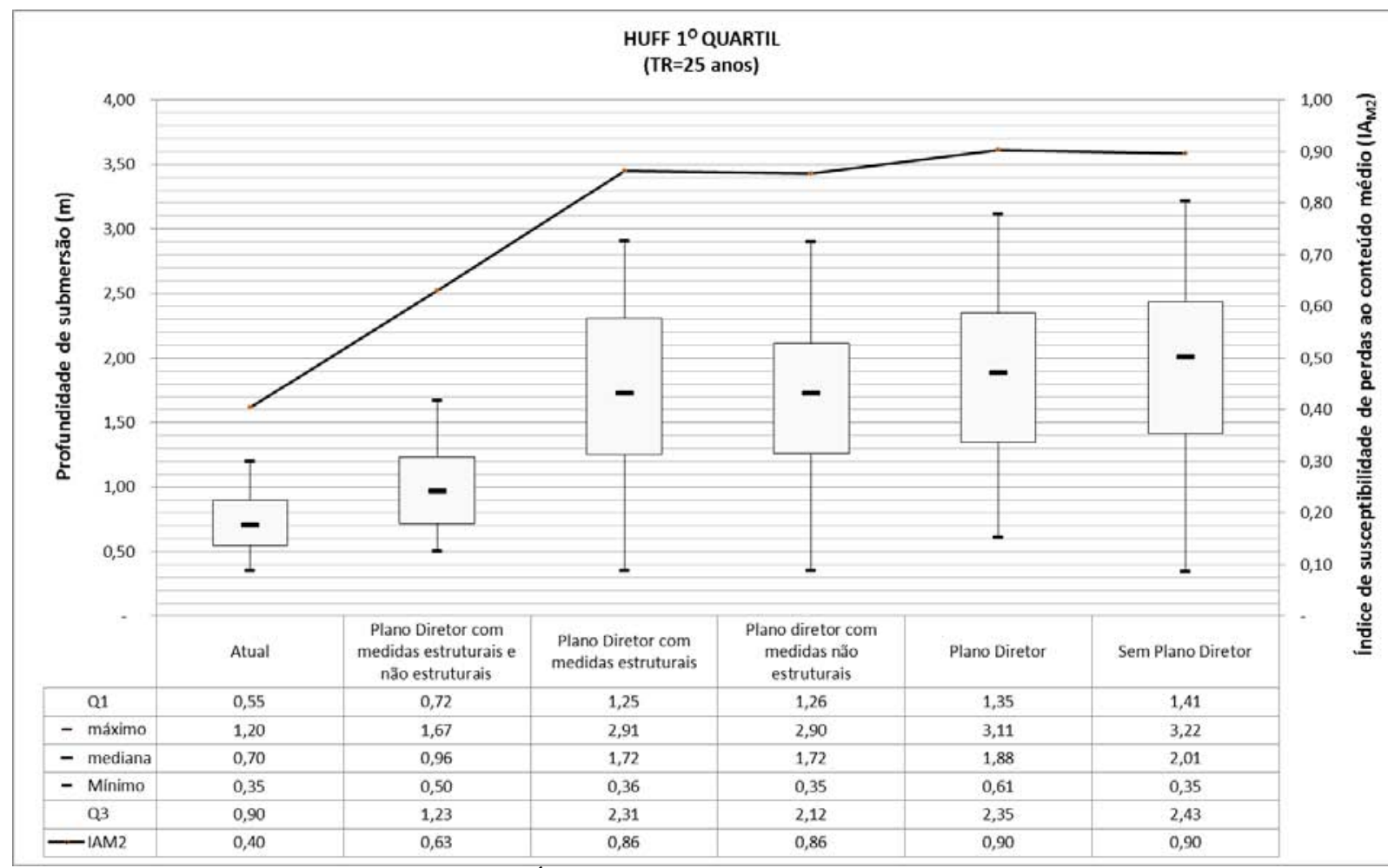

Figura 69 - Profundidade de submersão e Índice de ameaça da inundação ao conteúdo - (IA $\left.\mathrm{M}_{\mathrm{M} 2}\right)$ para um evento hidrológico com tempo de retorno de 25 anos pelo método de Huff $1^{\circ}$ quartil 


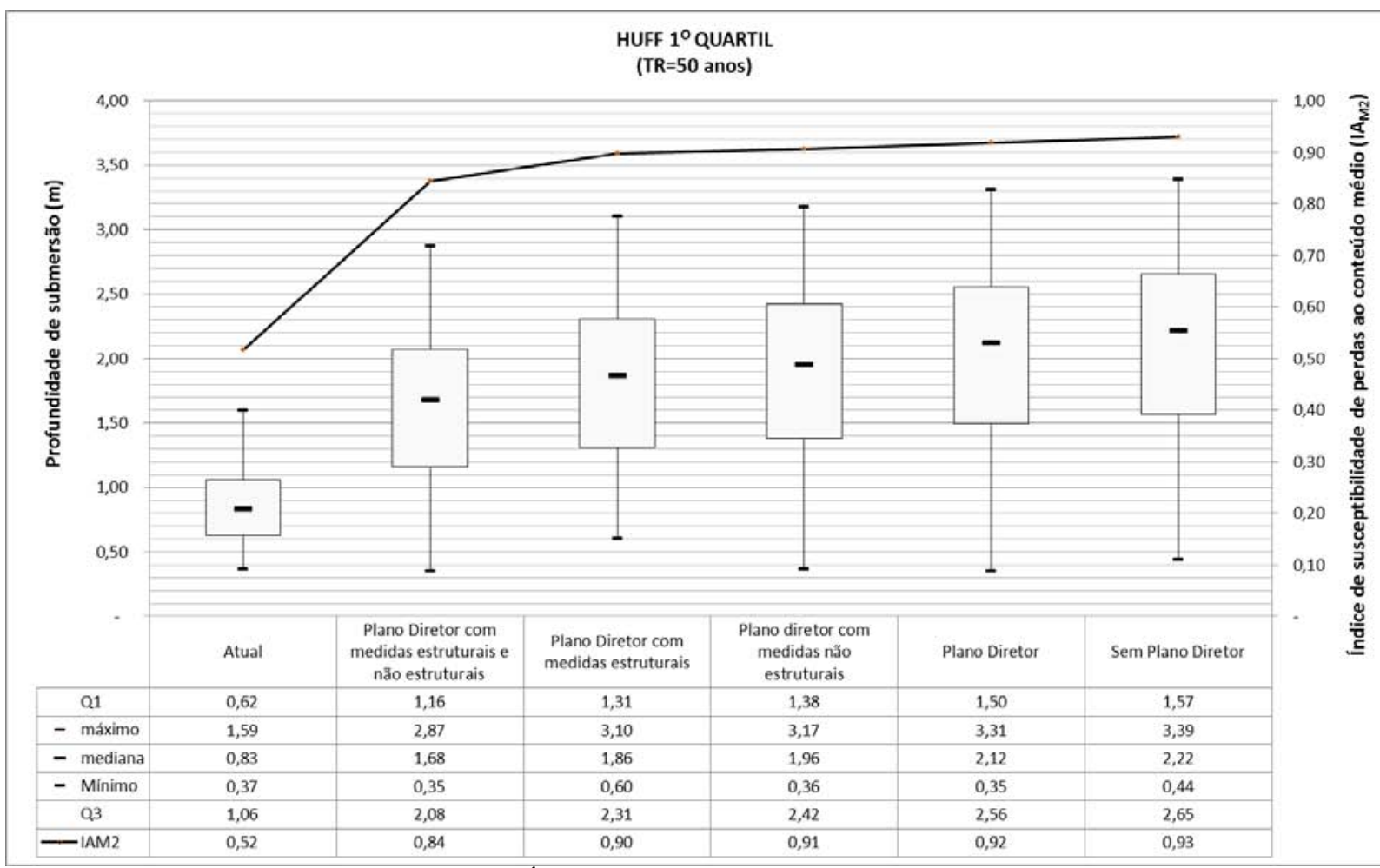

Figura 70 - Profundidade de submersão e Índice de ameaça da inundação ao conteúdo - $\left(\mathrm{IA}_{\mathrm{M} 2}\right)$ para um evento hidrológico com tempo de retorno de 50 anos pelo método de Huff $1^{\circ}$ quartil

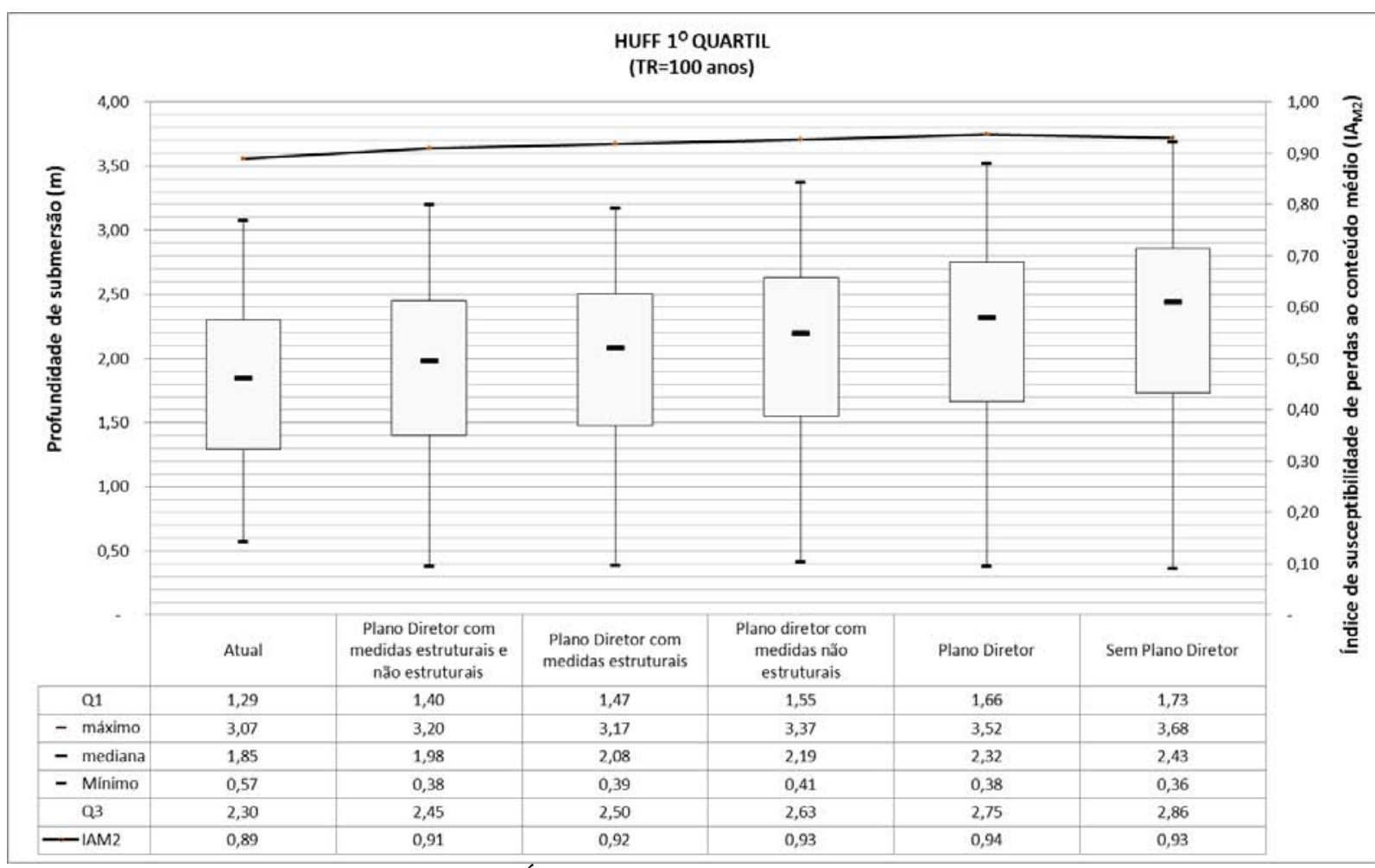

Figura 71 - Profundidade de submersão e Índice de ameaça da inundação ao conteúdo - $\left(\mathrm{IA}_{\mathrm{M} 2}\right)$ para um evento hidrológico com tempo de retorno de 100 anos pelo método de Huff $1^{\circ}$ quartil 


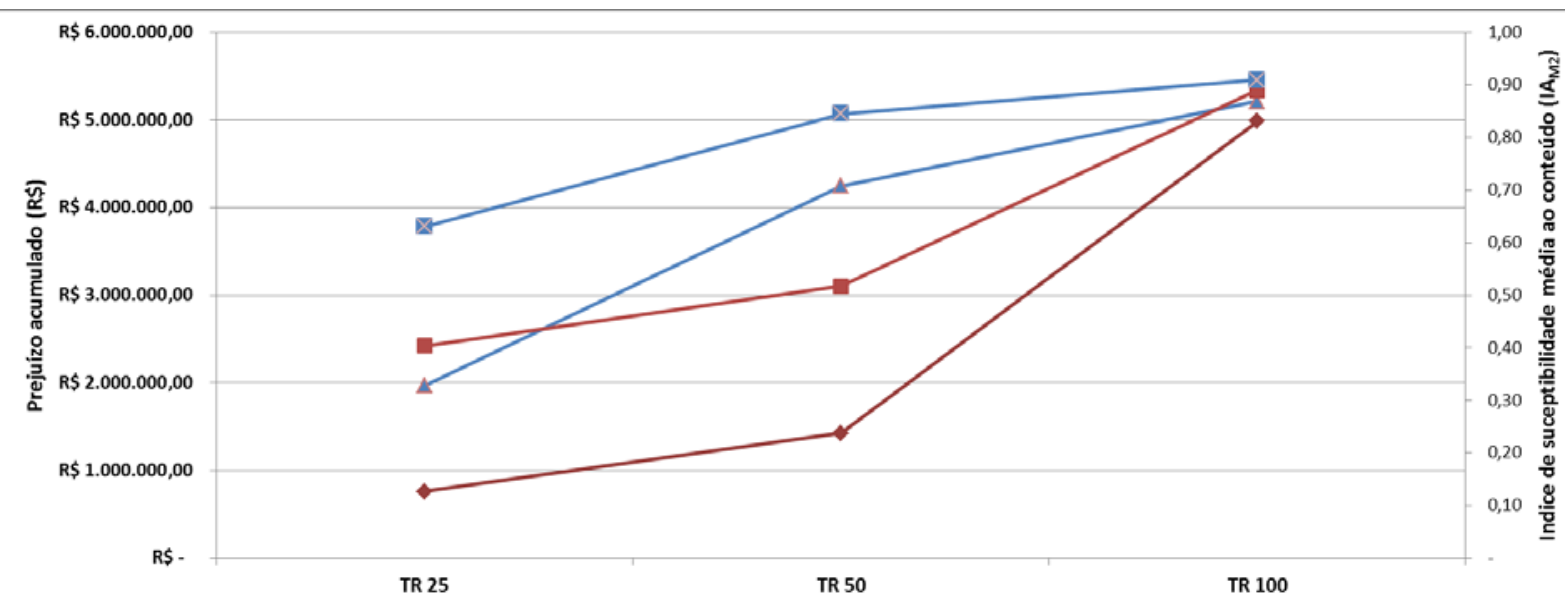

$\rightarrow$ Prejuizo acumulado - cenário atual $\longrightarrow$ Prejuizo acumulado - PD com med. Estruturais e não estruturais $=$-Indice IAM2 - Cenário atual $\rightarrow$ indice IAM2 - PD com med. estruturais e năo estruturais

Figura 72 - Comparação entre o índice I $\mathrm{A}_{\mathrm{M} 2}$ e o prejuízo acumulado entre o cenário atual e o cenário Plano Diretor com medidas estruturais e não estruturais pelo método de Huff $1^{\circ}$ quartil

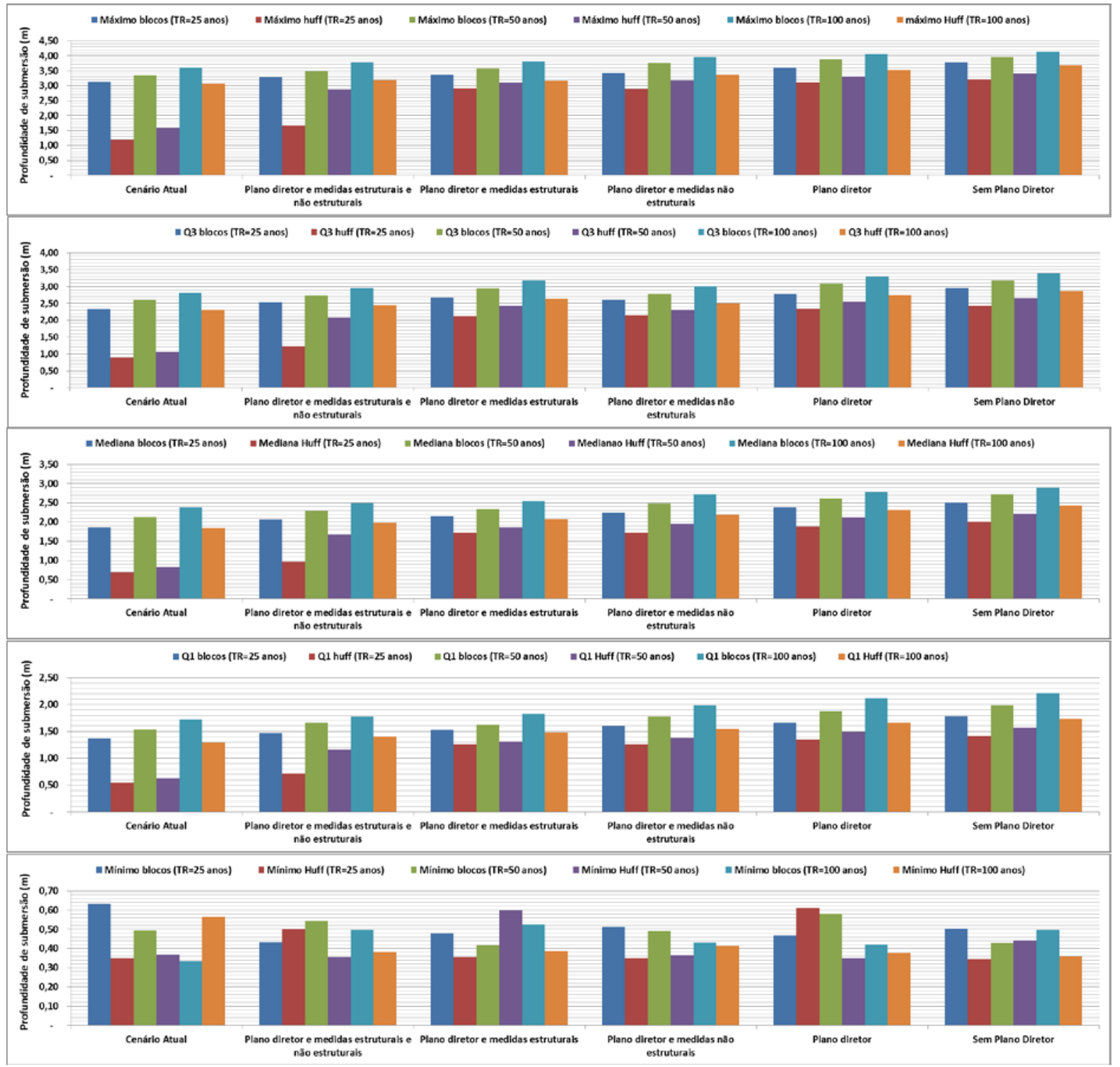

Figura 73 - Comparação entre as variáveis estatísticas pelo método blocos alternados e Huff $1^{0}$ quartil 
Através das Figuras 66 a 71 e da Figura 73, é possível verificar que as variações entre os métodos são mais significativas para os cenários de menor impacto (cenário atual e cenário Plano diretor com medidas estruturais e não estruturais), enquanto que para os outros métodos as diferenças obtidas entre as alturas de inundação são menos discrepantes.

A variável "mínimo" comporta-se de maneira diferente com relação as outras variáveis da análise, não obedecendo ao comportamento dessas frente ao impacto dos cenários. Isso ocorre devido a entrada de novas empresas na medida em que avança a mancha de inundação. Assim, é possível perceber, por exemplo, que para o cenário atual com TR 25 anos, a altura mínima de submersão de uma empresa foi de $0,56 \mathrm{~m}$, ao passo que para 100 anos foi de 0,36 m, tendo em vista a incorporação de novas empresas na mancha de inundação.

Pelo método dos blocos alternados para o cenário atual com TR de 25 anos, metade das empresas situa-se entre as alturas de submersão de 1,37 m e 2,34 m (Q1 e Q3, respectivamente) com mediana de 1,87 m; enquanto que para o TR de 100 anos, as variáveis encontram-se entre 1,72 m e 2,82 m, com mediana de 2,38 m. Para o cenário sem plano diretor, no TR de 25 anos essa variação encontra-se entre 1,79 m e 2,96 m, com mediana de 2,51 m e para o TR de 100 anos 2,21 m e 3,39 m com medianas de e 2,88 m respectivamente. A máxima altura foi obtida para o cenário sem plano diretor (TR 100 anos) com a altura de $4,14 \mathrm{~m}$.

Pelo método de Huff $1^{\circ}$ quartil, para o cenário atual com TR de 25 anos, metade das empresas situam-se entre as alturas de submersão de 0,55 m a 0,90 m (Q1 e Q3, respectivamente) com mediana de 0,70 m e para TR de 100 anos as alturas ficam entre 1,29 m e 2,30, com mediana de 1,85 m; enquanto que para o cenário sem plano diretor e TR 25 anos essa variação é de 1,41 m a 2,43 m com mediana de 2,01 m e para TR 100 anos é de 1,73 m a 2,86 m com medianas 2,43 respectivamente. O máximo obtido através desse método para o cenário sem plano diretor (TR 100 anos) foi de 3,68 m.

Dessa forma, é possível verificar diferenças relativas para as alturas de submersão decorrentes dos métodos de distribuição temporais de chuva. Com relação a mediana, a variação entre os métodos foi de 62\% para o cenário atual com TR de 25 anos, e de 22\% para o mesmo cenário com TR de 100 anos. Para o cenário sem plano diretor, essa diferença foi da ordem de 20\% para TR de 25 anos e $16 \%$ para TR de 100 anos. As diferenças mostram o quão significativas são as variações das alturas de inundação, ocasionadas pela distribuição temporal da precipitação, quando comparadas áreas em processo de urbanização (cenário 
atual) com relação a áreas urbanizadas (cenário sem plano diretor) e também para chuvas de elevados períodos de retorno.

Com relação ao $\mathrm{IA}_{\mathrm{M} 2}$ proposto por Cançado (2009), foi mostrado na Figura 72 que a curva do prejuízo acumulado possui boa confrontação com o índice proposto por Cançado (2009) para os cenários em que houve maiores variações quanto ao prejuízo acumulado das empresas, sugerindo que a curva baseada no índice de Cançado (2009) possui relação com o a curva baseada no prejuízo acumulado das empresas.

\subsection{Curvas de danos por profundidade de submersão (DPS)}

A curva de danos por profundidade de submersão é uma forma de apresentar os prejuízos individuais das empresas contidas na mancha de inundação. Os prejuízos são apresentados em termos de danos por área $\left(\mathrm{R} \$ / \mathrm{m}^{2}\right)$. Foram utilizadas as curvas por profundidade de submersão e divididas por categoria de empresas apresentadas no estudo de Milograna (2009) para a cidade de Itajubá (MG) para relacionar o tipo de atividade comercial com danos por área construída. Dessa forma, o estudo parte da hipótese de que os valores obtidos pelas empresas de Itajubá (MG) podem ser aplicados em outras localidades. Apesar das discrepâncias possíveis de ocorrem com a utilização de curvas de outras localidades, esse estudo ainda é bastante incipiente em termos nacionais, sendo necessária a elaboração de um número maior de curvas para realizar análises mais aprofundadas sobre o tema.

Tendo em vista a incerteza de cenários futuros, optou-se por compor as curvas por profundidade de submersão apenas para o cenário atual para os tempos de retorno de 25, 50 e 100 anos. As curvas por tipo de atividade comercial para o evento de maior impacto (blocos alternados; TR=100 anos) são apresentadas na Figura 75. Nesta figura, portanto, é apresentado a totalidade das empresas contidas na mancha de inundação. 


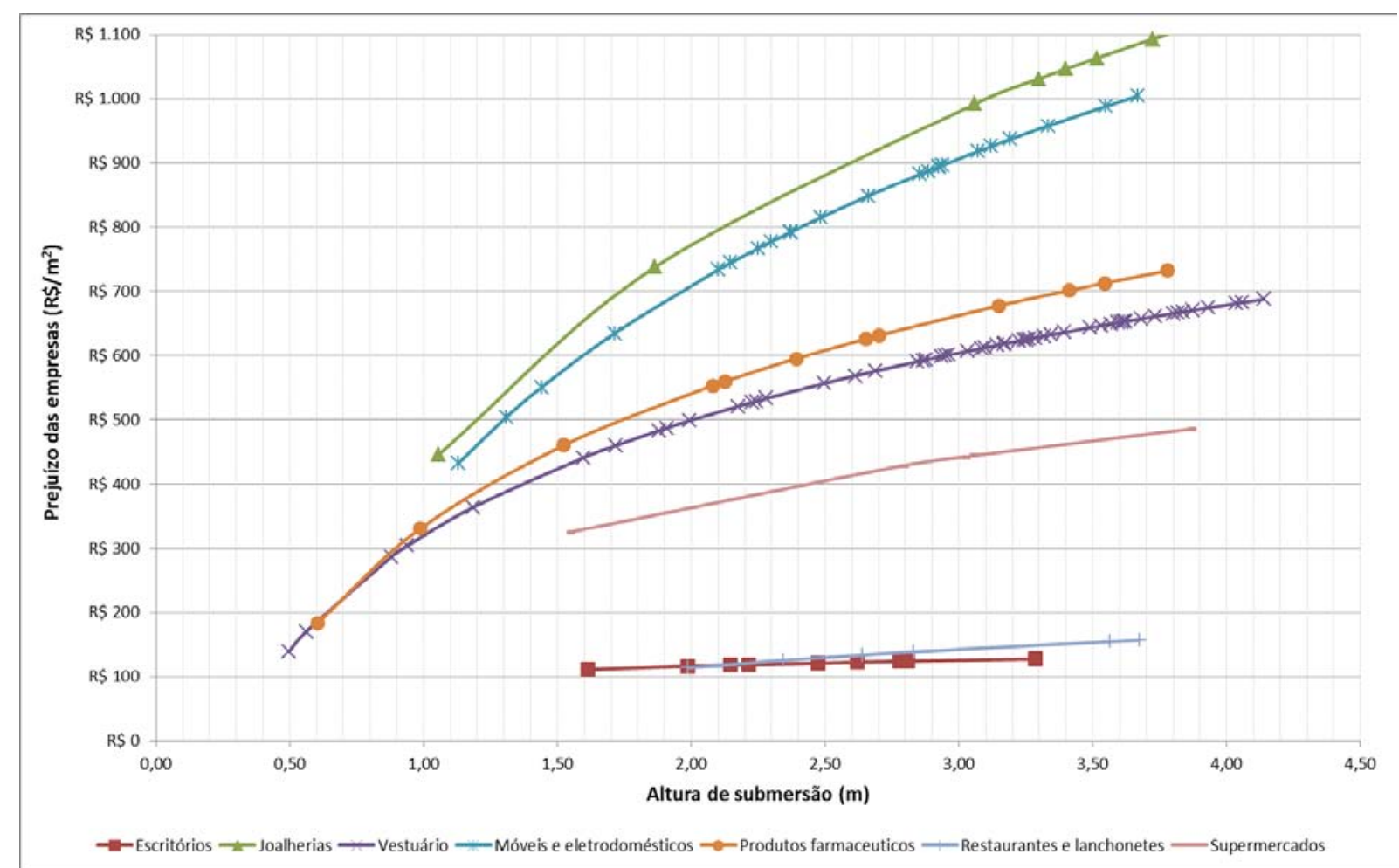

Figura 74 - Danos por profundidade de submersão por categoria de atividade comercial para a distribuição temporal blocos alternados TR 100 anos cenário sem plano diretor

Pela Figura 74, percebe-se que escritórios e lanchonetes são os tipos de estabelecimento que sofrem um menor prejuízo por metro quadrado de área, da ordem de $\mathrm{R} \$ / \mathrm{m}^{2} 100,00$, enquanto que joalherias e móveis e eletrodomésticos são as que sofrem os maiores prejuízos, com valores que podem chegar a $\mathrm{R} \$ / \mathrm{m}^{2} 1.100,00$.

Dentre as empresas presentes na mancha de inundação para o cenário sem plano diretor com TR 100 anos, destaca-se a presença de empresas de vestuários (55), seguida das empresas de móveis e eletrodomésticos (23) e de farmácias e drogarias (12), influenciando sobremaneira na curva de tendência logarítmica de danos por profundidade de submersão das empresas contidas na mancha de inundação.

\subsubsection{Blocos alternados}

A curva de danos por profundidade de submersão das empresas contidas na mancha de inundação pelo método de distribuição temporal das chuvas blocos alternado para o cenário atual e tempo de retorno de 25, 50 e 100 anos é apresentado na Figura 75. 


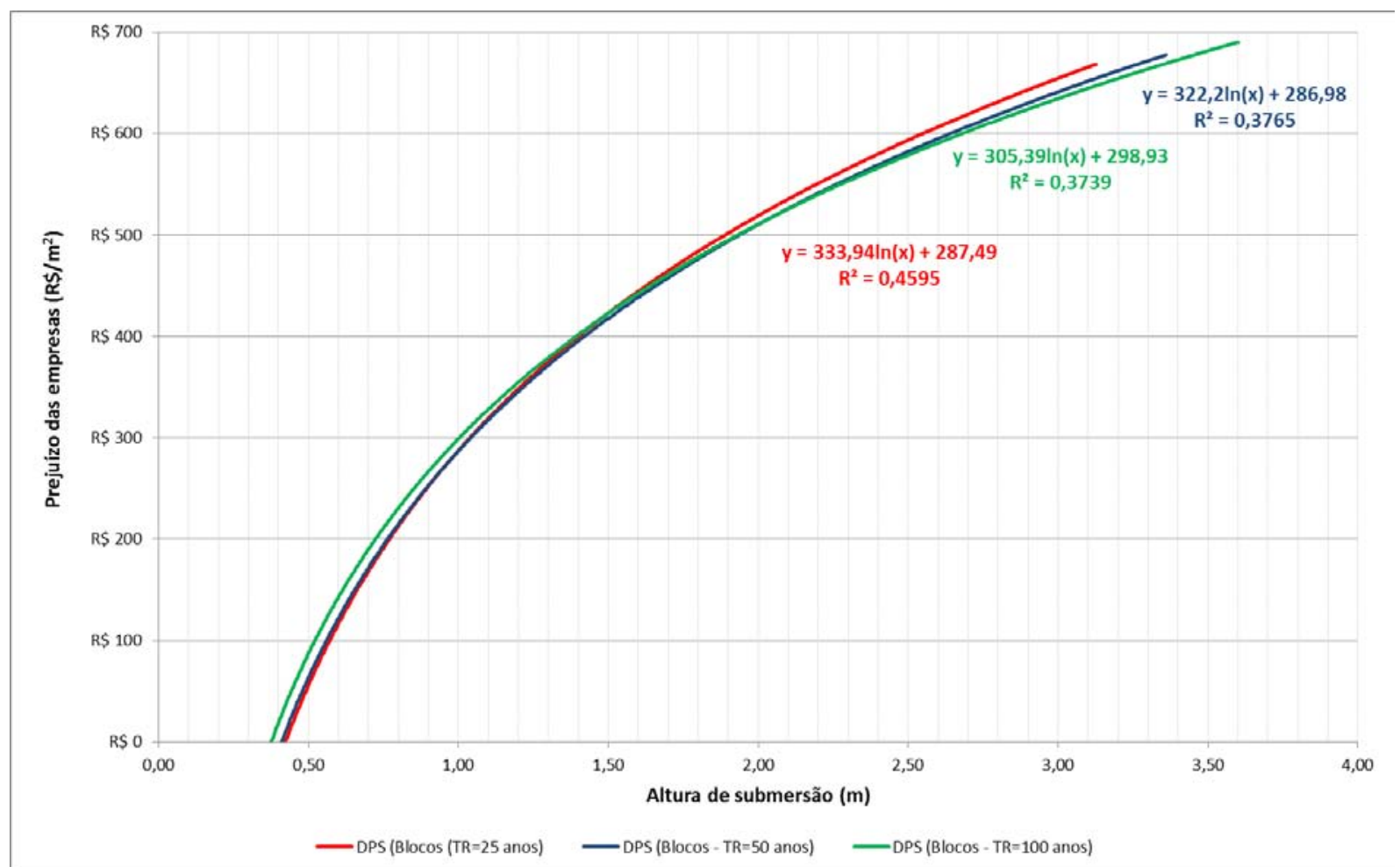

Figura 75 - Curva de Danos por Profundidade de Submersão (DPS) pelo método dos blocos alternados

A curva mostrada não apresenta diferenças significativas para o tempo de retorno propostos nesta pesquisa. Utilizando este método, as empresas atingiram alturas de submersão máxima entre 3,0 m e 3,7m, altura a qual se atinge o prejuízo máximo entre $\mathrm{R} \$ / \mathrm{m}^{2} 670,00$ e $\mathrm{R} \$ / \mathrm{m}^{2} 700,00$, para tempo de retorno entre 25 e 100 anos. Esse fato deve-se a linearidade dos prejuízos obtidos por esse método, que desencadeou prejuízos próximos ao máximo já para o tempo de retorno de 25 anos.

\subsubsection{Huff $1^{\circ}$ quartil}

A curva de danos por profundidade de submersão para o método de Huff $1^{\circ}$ quartil é apresentado na Figura 76. 


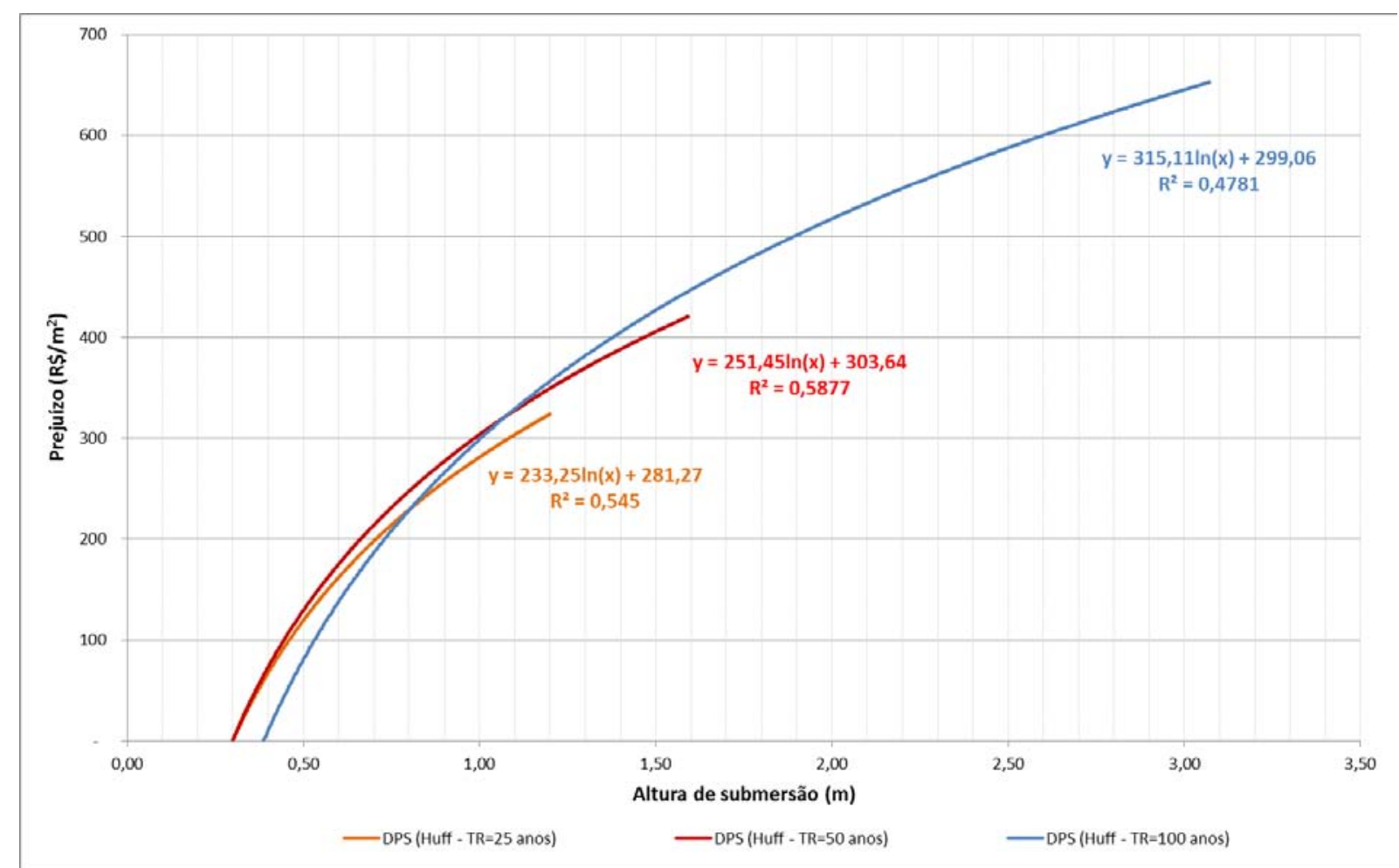

Figura 76 - Curva de danos por profundidade de submersão (DPS) pelo método de Huff $1^{\circ}$ quartil

A curva DPS para o método de Huff $1^{\circ}$ quartil apresenta diferenças mais significativas com relação as curvas obtidas para o método do blocos alternados, tendo em vista a altura de inundação a que se encontram as empresas em cada tempo de retorno.

Para o tempo de retorno de 25 anos, as empresas encontram-se submergidas até a altura de 1,2 m, com prejuízo de até $\mathrm{R} \$ / \mathrm{m}^{2}$ 315,00; para TR de 50 anos, altura de 1,60 m e $\mathrm{R} \$ / \mathrm{m}^{2}$ de 420,00; para TR 100 anos, altura de 3,1 m e $\mathrm{R} \$ / \mathrm{m}^{2}$ 650,00. Cabe salientar que as curvas pelo método de Huff $1^{\circ}$ quartil atingiram coeficiente de determinação $\left(\mathrm{R}^{2}\right)$ melhores do que pelo método dos blocos alternados, tendo em vista a concentração dos imóveis em alturas de inundação menos abrangente.

\subsubsection{Comparação entre Huff $1^{\circ}$ quartil e blocos alternados}

Para analisar os efeitos do método de distribuição temporal das precipitações sob as curvas de danos por profundidade de submersão, foram inseridas no mesmo gráfico as curvas representativas dos métodos para seu respectivo tempo de retorno. As curvas comparativas são apresentadas para o cenário atual com tempo de retorno de 25, 50 e 100 anos nas Figuras 77 a 79. 


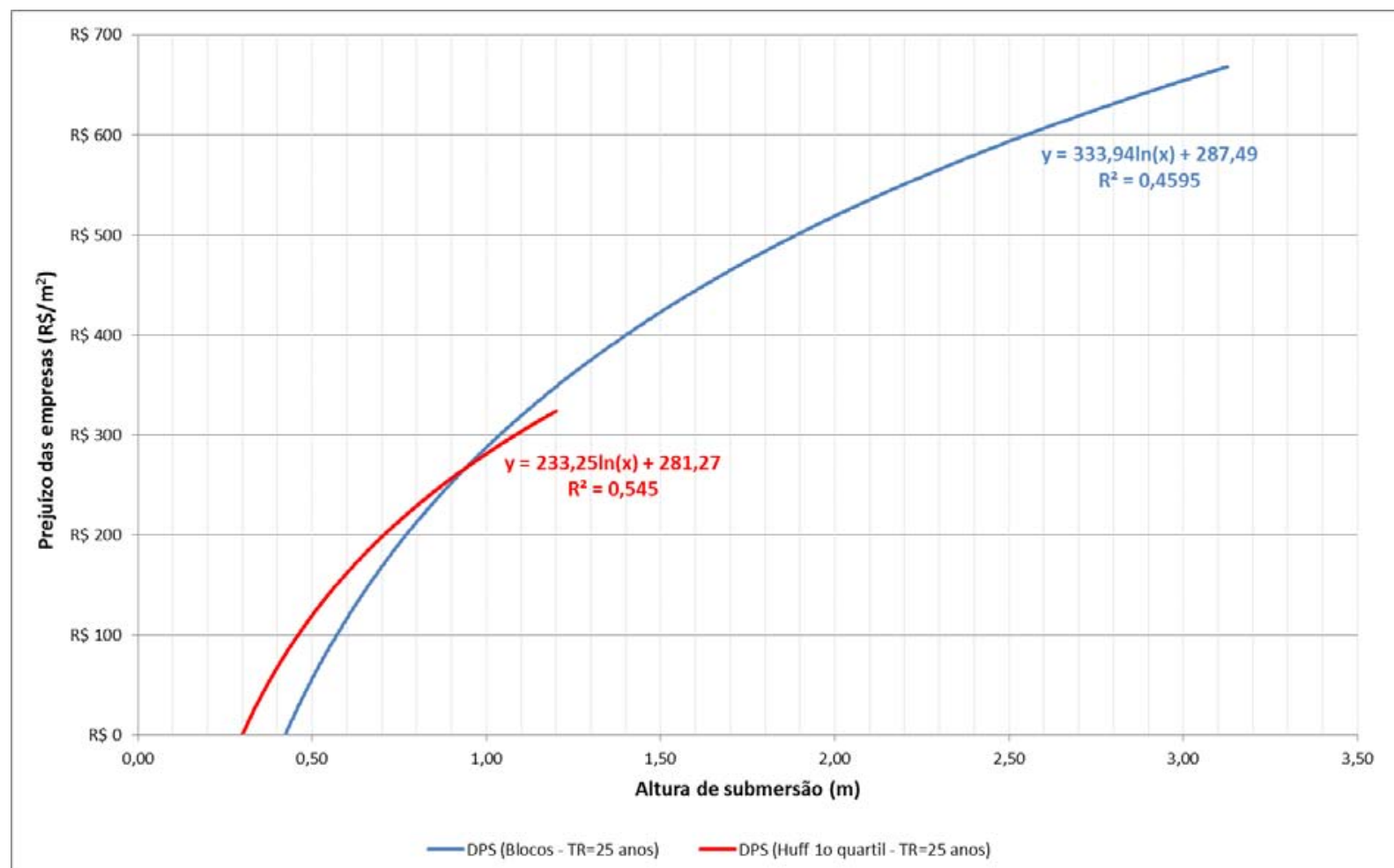

Figura 77 - Comparação entre as curvas DPS para Huff $1^{0}$ quartil e blocos alternados para o tempo de retorno de 25 anos

Para o tempo de retorno de 25 anos, a curva DPS no método de Huff $1^{\circ}$ quartil apresentou melhor coeficiente de correlação $\left(\mathrm{R}^{2}\right)$ com relação a curva para o mesmo tempo de retorno pelo método dos blocos alternados. Para método de Huff $1^{\circ}$ quartil, as alturas de submersão atingiram o máximo de $1,2 \mathrm{~m}$ e $\mathrm{R} \$ \mathrm{~m}^{2} 320,00$, enquanto que para blocos alternados a altura máxima foi de $3,1 \mathrm{~m}$ e $\mathrm{R} \$ / \mathrm{m}^{2} 680,00$.

Outra característica é que as curvas se cruzam e as empresas atingem o mesmo prejuízo por metro quadrado $\left(\mathrm{R} \$ / \mathrm{m}^{2}\right)$ na altura de submersão de $0,95 \mathrm{~m}$, as quais apresentam prejuízo da ordem de $\mathrm{R} \$ / \mathrm{m}^{2} 270,00$ por empresa. 


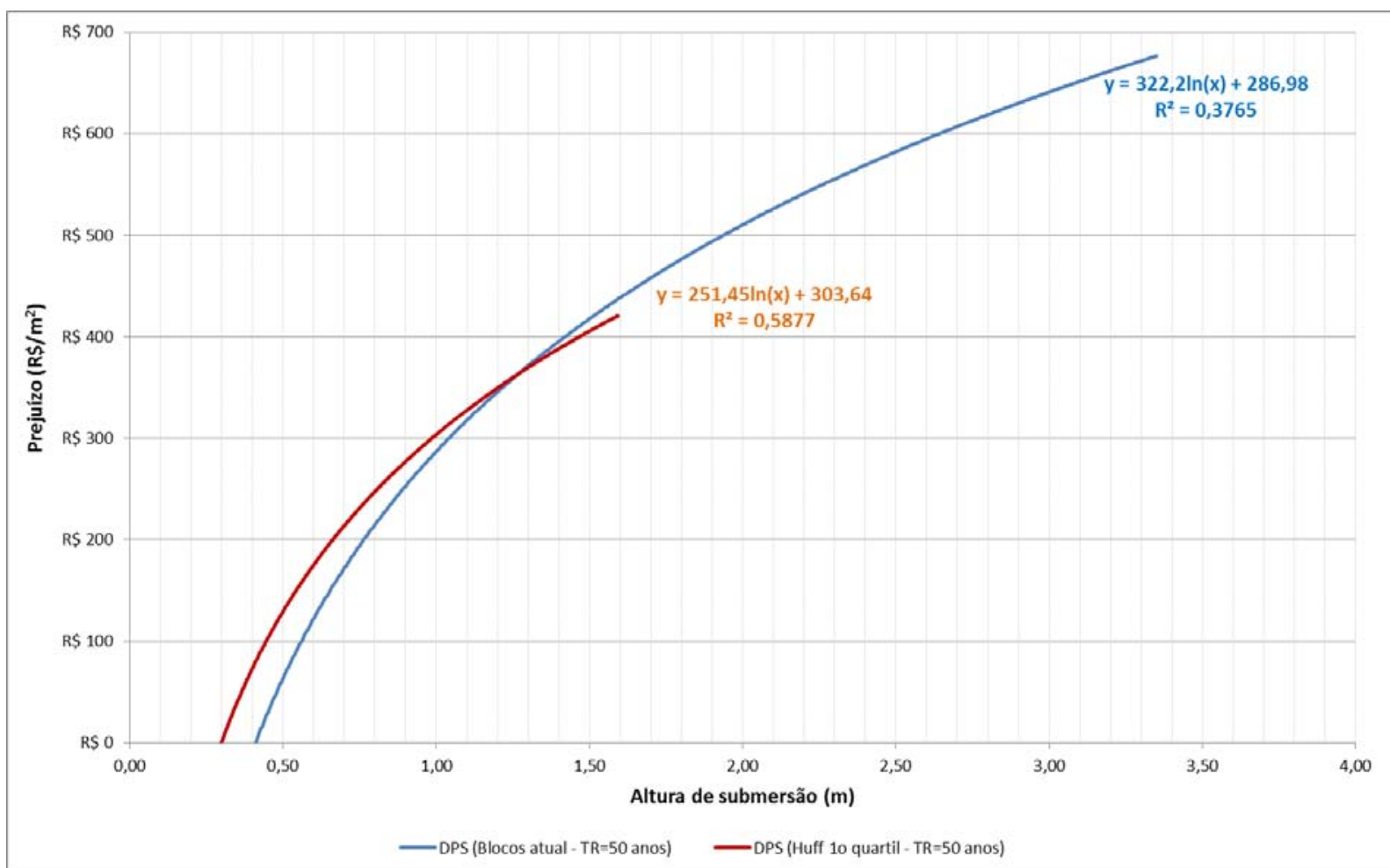

Figura 78 - Comparação entre as curvas DPS para Huff $1^{\circ}$ quartil e blocos alternados para o tempo de retorno de 50 anos

Para o tempo de retorno de 50 anos, a altura máxima de submersão para o método de Huff $1^{\circ}$ quartil foi de $1,6 \mathrm{~m}$, atingindo prejuízo de $\mathrm{R} \$ / \mathrm{m}^{2} 415,00$, enquanto que para o método blocos alternados esta altura foi de $3,35 \mathrm{~m}$ e $\mathrm{R} \$ / \mathrm{m}^{2}$ 680,00. A curva obteve melhor coeficiente de correlação para o método de Huff $1^{\circ}$ quartil. As curvas de prejuízos e encontraram na altura de submersão de $1,3 \mathrm{~m}$, que representa um prejuízo de $\mathrm{R} \$ / \mathrm{m}^{2} 360,00$. 


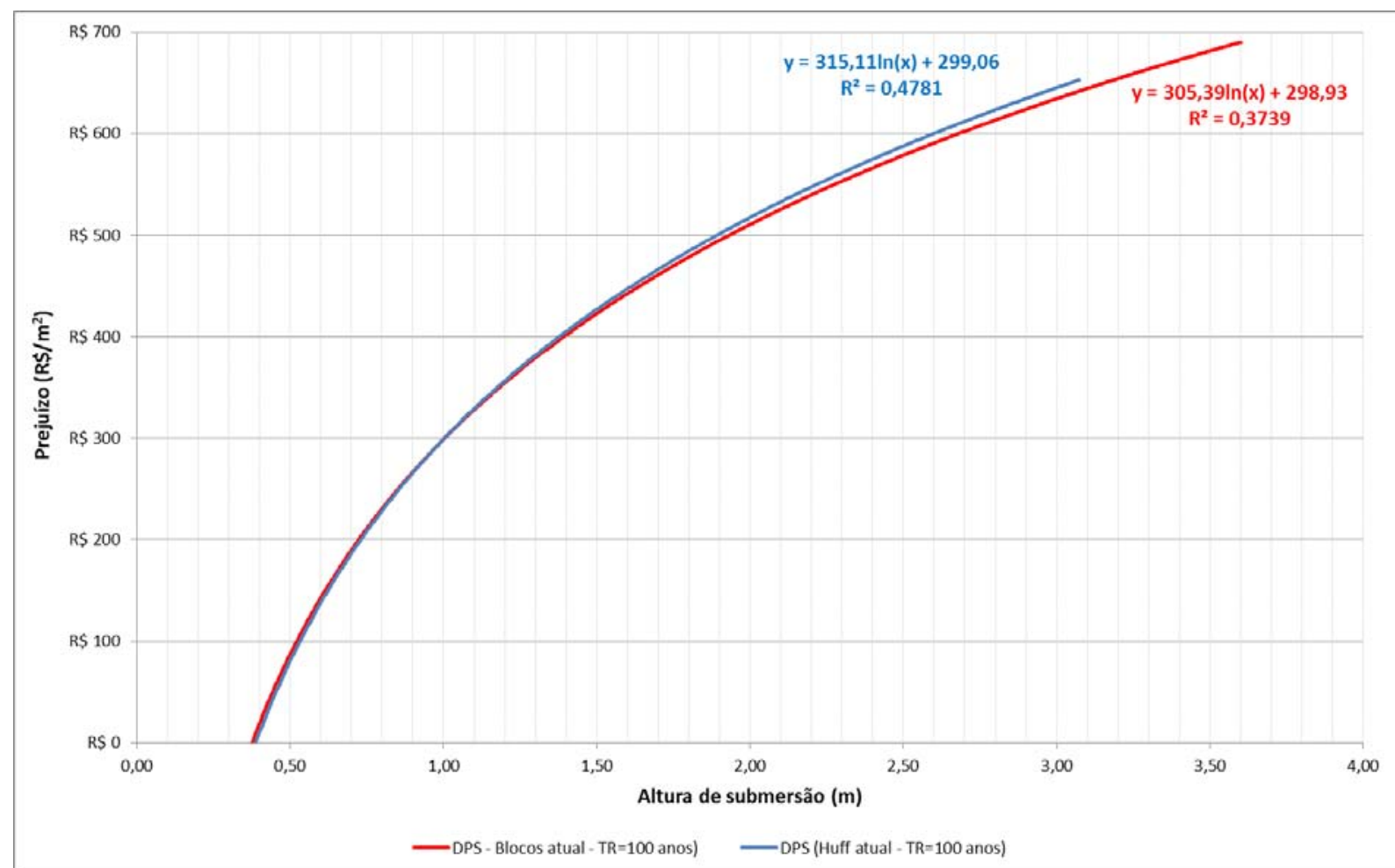

Figura 79 - Comparação entre as curvas DPS para Huff $1^{0}$ quartil e blocos alternados para o tempo de retorno de 100 anos

As curvas com tempo de retorno de 100 anos não apresentaram diferenças significativas em sua composição. Pelo método de Huff $1^{\circ}$ quartil, a altura limite foi 3,1 m e prejuízo de $\mathrm{R} \$ / \mathrm{m}^{2} 650,00$, enquanto que pelo método blocos alternados a altura foi de 3,6 m e $\mathrm{R} \$ / \mathrm{m}^{2} \mathrm{R} \$ 695,00$. A curva de Huff $1^{\circ}$ quartil obteve melhor coeficiente de correlação.

\subsection{Curva de prejuízo acumulado por altura de submersão}

Para representar o prejuízo acumulado das empresas pelos métodos de distribuição temporal das chuvas nos respectivos tempos de retorno, são propostas curvas de danos acumulados por profundidade de submersão. Dessa forma, é possível calcular os prejuízos das empresas contidas na mancha de inundação de acordo sua altura de inundação. Assim, é possível prever o prejuízo decorrente de uma dada inundação de acordo o total precipitado.

Assim, são apresentadas nas Figuras 80 e 81 as curvas de danos para a totalidade das empresas contidas na mancha de inundação pelos dois métodos de distribuição temporal das chuvas. O eixo y mostra o prejuízo acumulado das empresas contidas na mancha de inundação decorrente da altura de inundação, mostrada no eixo x. 


\subsubsection{Blocos alternados}

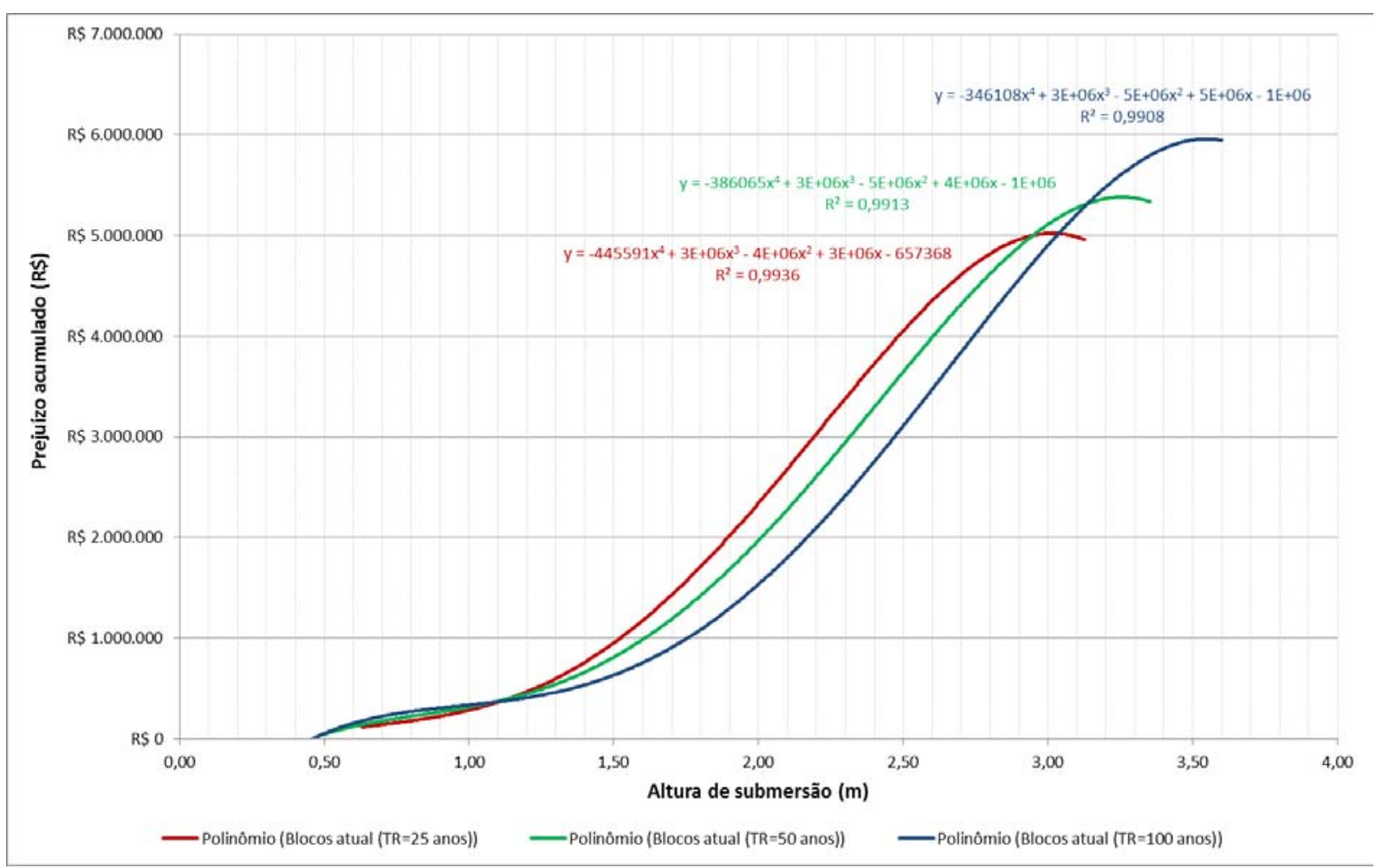

Figura 80 - Curva de prejuízo acumulado das empresas presentes na mancha de inundação por profundidade de submersão pelo método dos blocos alternados

As curvas de inundação mostram que para os tempos de retorno entre 25 e 100 anos, ocorrem prejuízos da ordem de $\mathrm{R} \$$ 5.000.000,00 a R \$ 6.000.000,00, com altura de submersão máxima entre 3,1 m a 3,6 m. As curvas possuem o mesmo valor de prejuízo quando atingem altura de submersão de 1,15 m.

Uma consideração importante a ser observada neste tipo de curva é sua concavidade. Através da visualização, é possível perceber que, para os menores tempo de retorno, são previstos maiores prejuízos acumulados na mesma altura de inundação. Como exemplo, para a altura de 2,5 m, o prejuízo acumulado é de R\$3.000,000,00 (TR de 100 anos); para o TR de 50 anos este valor é de R\$3.500.000,00, e para o TR de 25 anos é de R \$.000.000,00.

Essa proporcionalidade indireta (o aumento de um ocasiona a diminuição de outro) está relacionada, no exemplo acima, a quantidade de empresas contidas na mancha de inundação para um dado tempo de retorno em uma dada altura, ou seja, existem mais empresas contidas na mancha de inundação até a altura de 2,5 m para um tempo de retorno de 25 anos do que para tempo de retorno de 100 anos na mesma altura, já que neste ultimo as empresas já se encontram contidas em alturas de submersão mais elevadas. Assim, as curvas 
devem ser aplicadas apenas a chuva que a representa, não sendo factível a análise comparativa entre ambas.

Para melhor elucidar o exemplo, existem 86 empresas até a altura de submersão de 2,5 m para o tempo de retorno de 25 anos, enquanto que para TR de 50 anos esse número é de 79 e para TR 100 anos é de 68 empresas.

\subsubsection{Huff $1^{\circ}$ quartil}

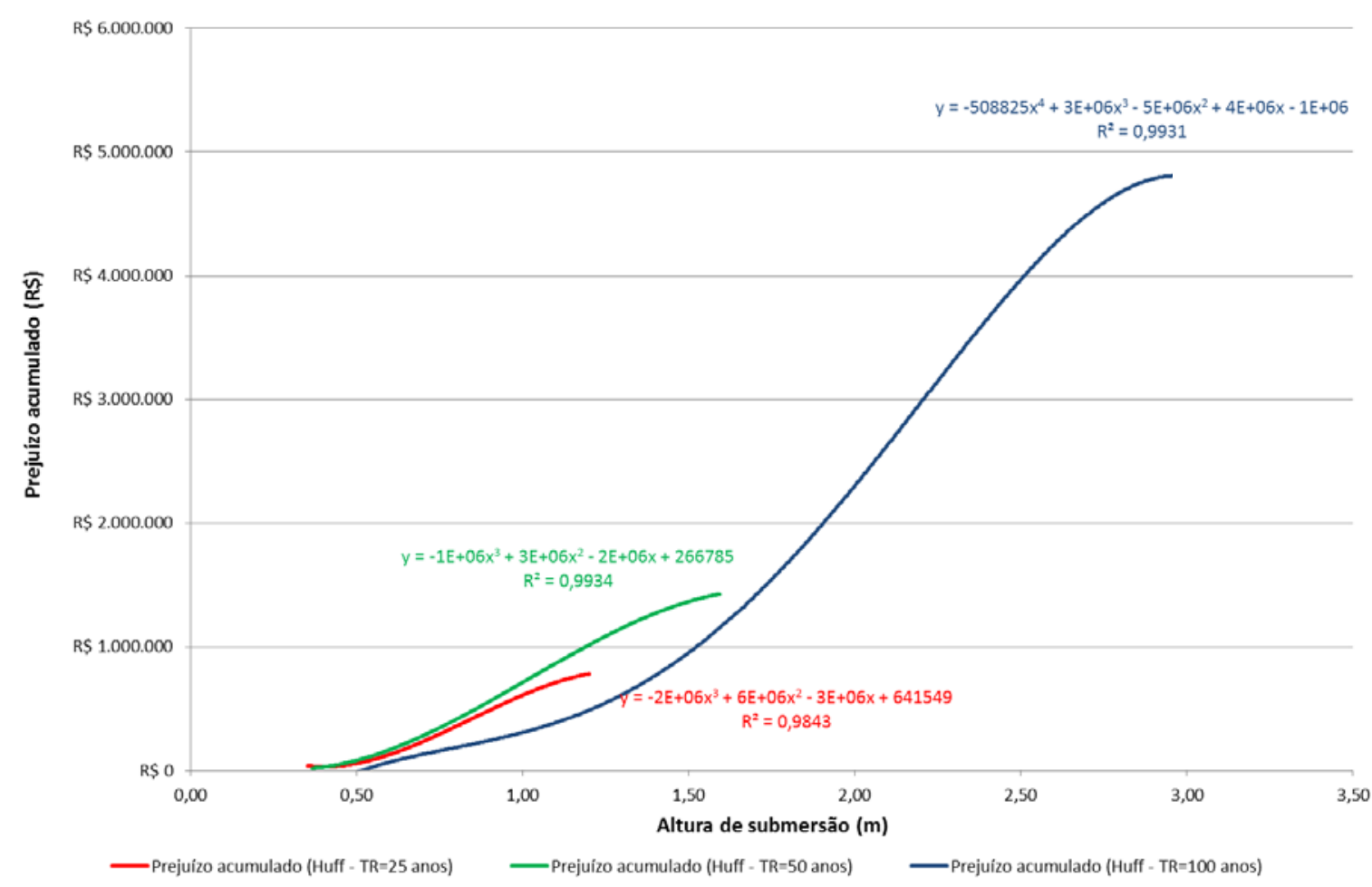

Figura 81 - Curva de prejuízo acumulado das empresas presentes na mancha de inundação por profundidade de submersão pelo método de Huff $1^{\circ}$ quartil

As curvas de prejuízo acumulado por tempo de retorno para Huff $1^{\circ}$ quartil possuem formas bastante discrepantes, em decorrência da altura de submersão que atingem as empresas. Novamente, as curvas com menor tempo de retorno apresentam maior prejuízo quando comparadas com a altura de submersão a que a mancha de inundação foi atingida.

\subsubsection{Comparação entre os métodos blocos alternados e Huff $1^{\circ}$ quartil}

Devido a grande sensibilidade que a distribuição temporal das chuvas representa aos prejuízos das empresas decorrentes das inundações, foram elaborados gráficos que 
compararam os prejuízos acumulados pelos dois métodos. Os gráficos são apresentados nas Figuras 82 a 84.

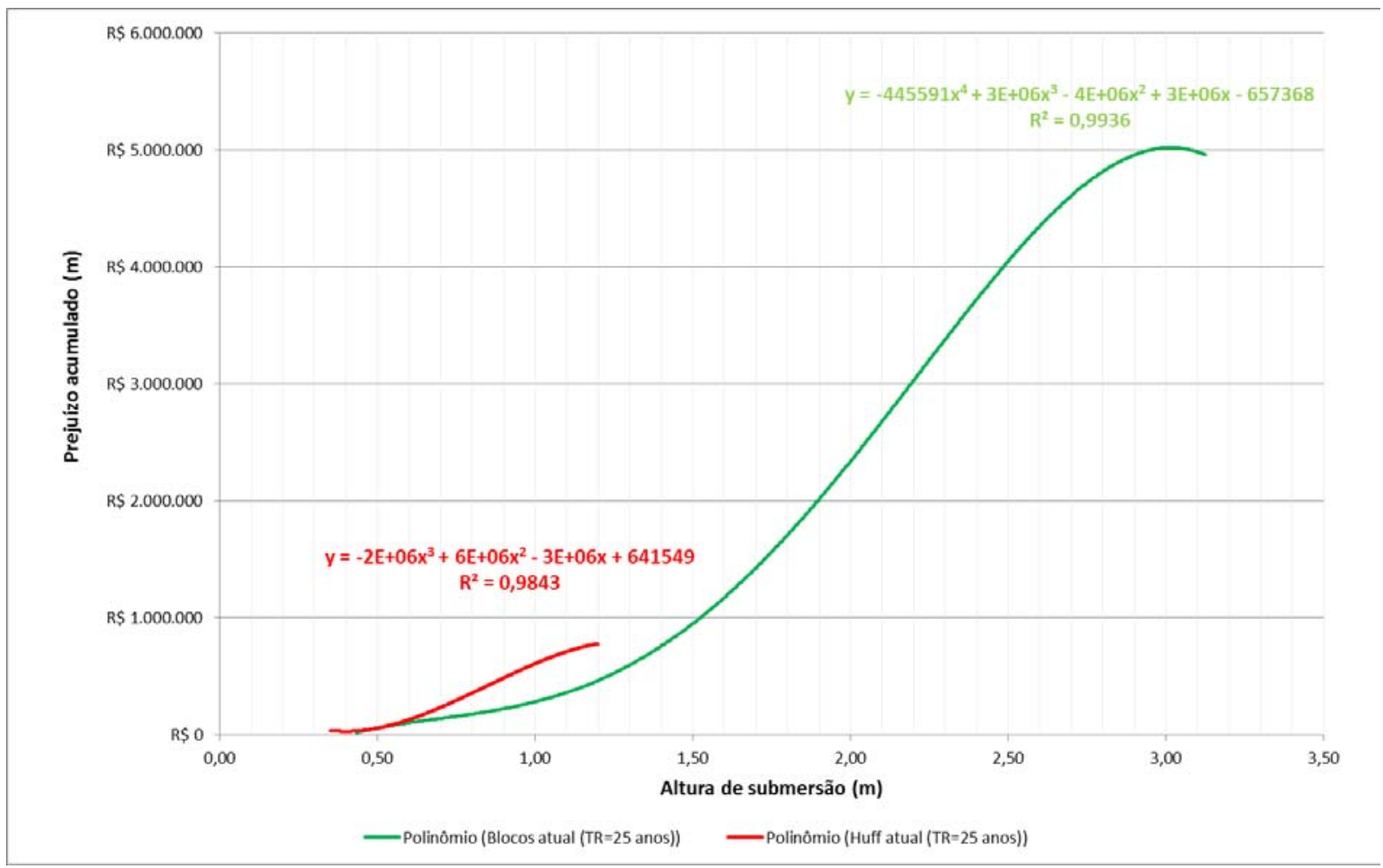

Figura 82 - Comparação entre as curvas de prejuízo acumulado por altura de submersão para o tempo de retorno de 25 anos 


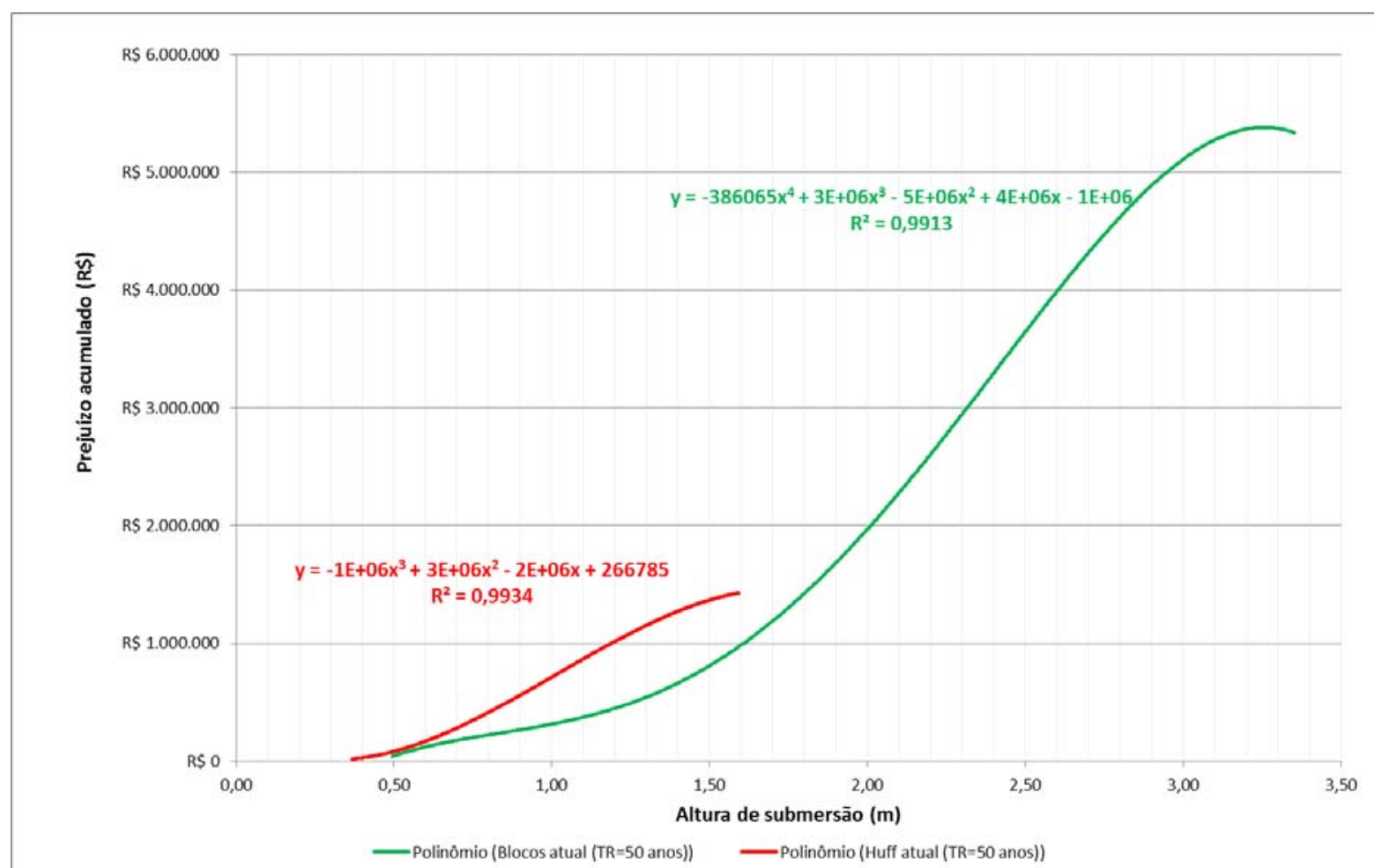

Figura 83 - Comparação entre as curvas de prejuízo acumulado por altura de submersão para o tempo de retorno de 50 anos

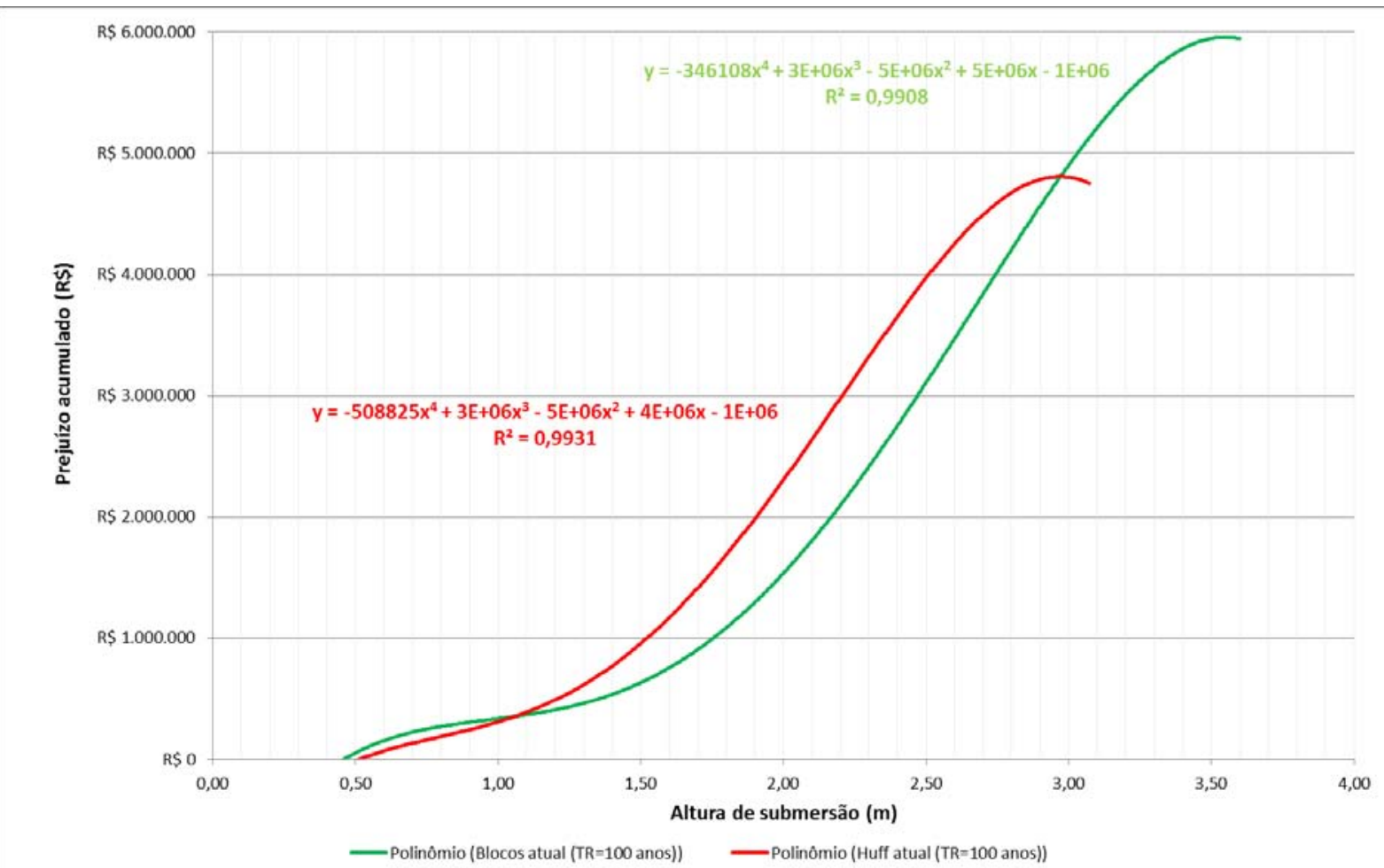

Figura 84 - Comparação entre as curvas de prejuízo acumulado por altura de submersão para o tempo de retorno de 100 anos

As curvas apresentaram grandes diferenças para o mesmo tempo de retorno diante das diferentes distribuições temporais, principalmente para os tempos de retorno de 25 e 50 
anos (cenário de menor impacto). Para o tempo de retorno de 100 anos as curvas se aproximaram para os métodos analisados.

Outra variável analisada foi o número de empresas susceptíveis a danos por tempo de retorno, considerando que os imóveis susceptíveis são aqueles encontrados acima de 0,35 m de altura de submersão. As empresas contidas na mancha de inundação são apresentadas na Figura 85.

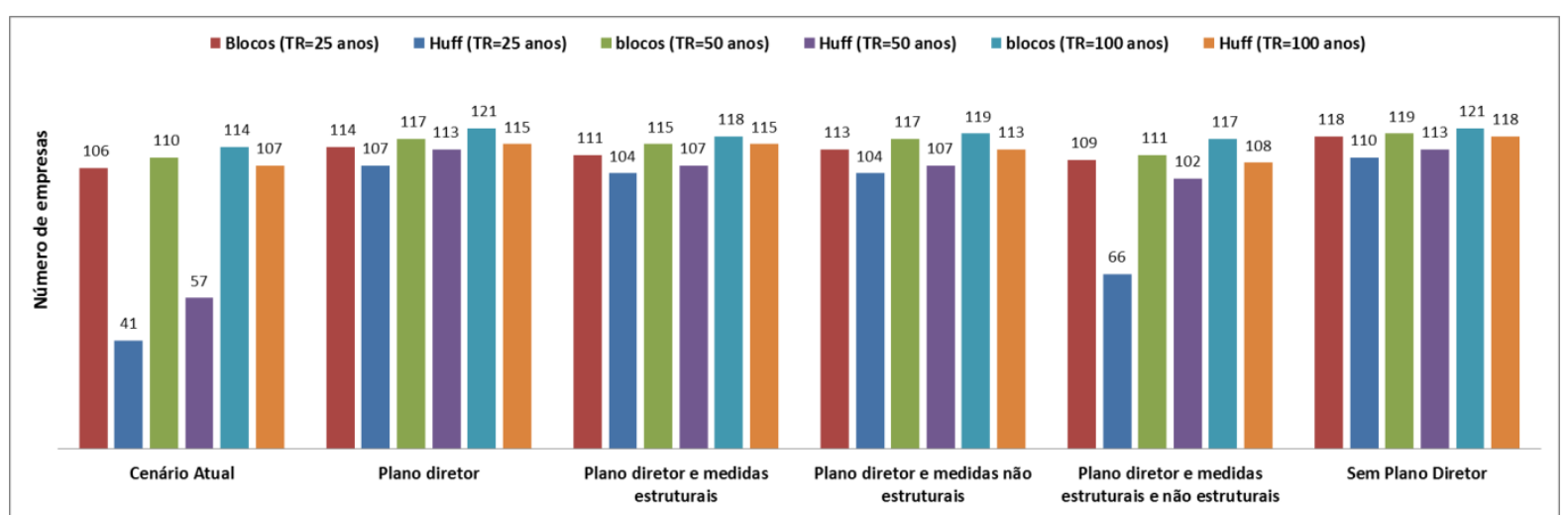

Figura 85 - Número de empresas contidas na mancha de inundação utilizando o método de distribuição temporal das chuvas pelos métodos de Huff $1^{\circ}$ quartil e blocos alternados

É possível verificar pelo gráfico que para eventos com tempo de retorno de 100 anos, as medidas compensatórias de controle e planejamento perdem a eficácia e o número de empresas susceptíveis a danos no cenário atual é próximo ao número de empresas contidas no cenário 6, de maior magnitude.

Ressalta-se também que as medidas estruturais e as medidas não estruturais obtiveram praticamente a mesma eficácia quanto ao número de empresas susceptíveis a inundação em cada cenário, que mostram que obras hidráulicas e medidas de controle de uso e ocupação do solo podem ter o mesmo efeito quanto à contenção de enchentes.

Além disso, o número de empresas contidas no TR 25 anos pelos blocos alternados e para o TR 100 anos para Huff $1^{\circ}$ quartil foi praticamente o mesmo em todos os cenários, fato também verificado com relação a vazão máxima (Tabela 14), que demonstra correlação entre a vazão obtida e o número de empresas contidas na mancha de inundação.

São apresentadas na Figura 86 as diferenças entre as variáveis estatísticas para os dois métodos de distribuição temporal das precipitações. 


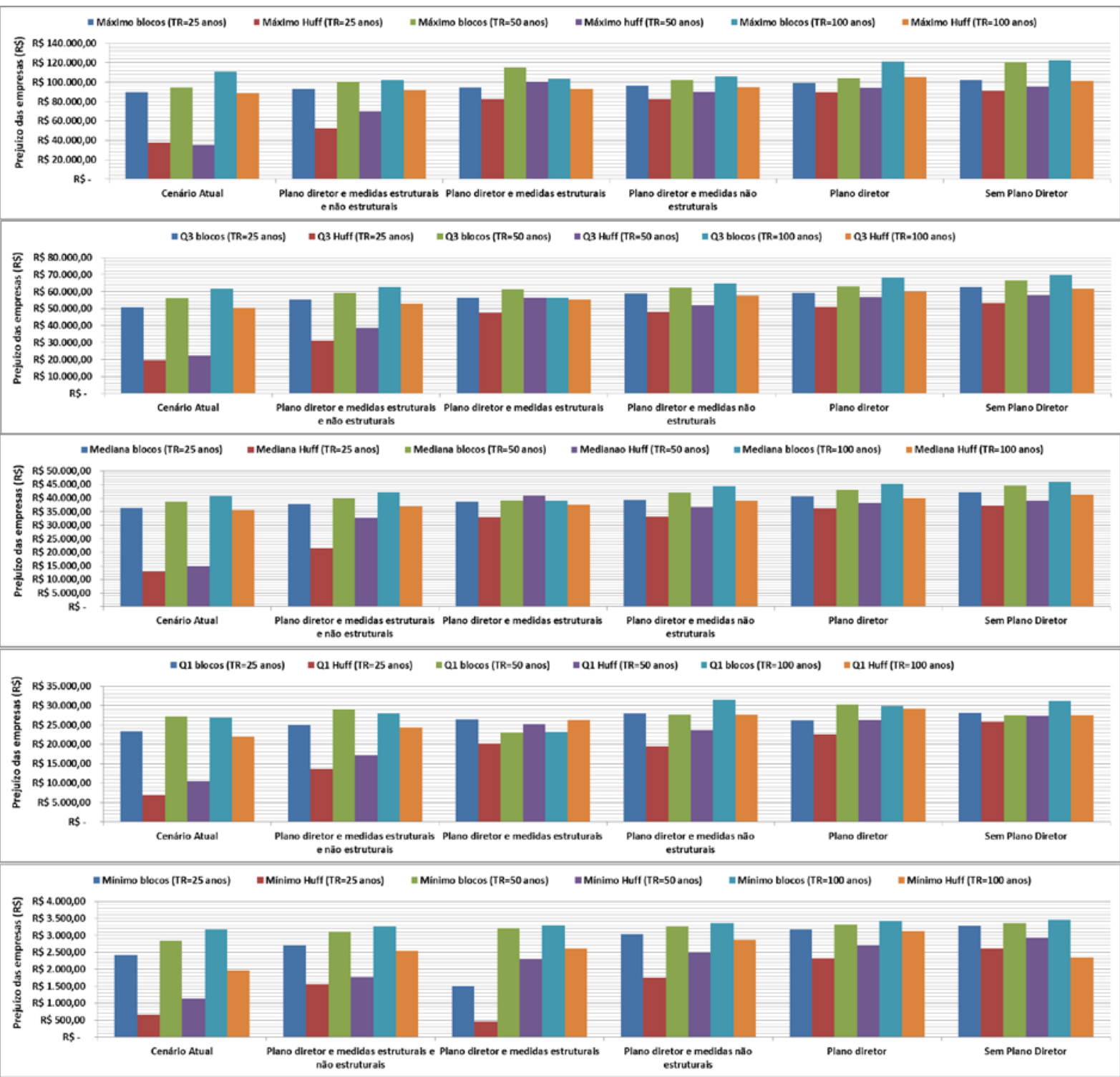

Figura 86 - Comparação entre os prejuízos das empresas pelo método de distribuição temporal blocos alternados e Huff $1^{\circ}$ quartil

Através da comparação entre os prejuízos das empresas pelos métodos de distribuição, é possível perceber grandes discrepâncias entre os valores atingidos principalmente para o cenário 1 (atual) e para o cenário 5 (Plano Diretor e medidas estruturais e não estruturais).

A variável "mínimo” não segue as mesmas correlações das outras variáveis, e mostra valores maiores para cenários de menor impacto. Essas constatações também foram observadas na análise das profundidades de submersão (item 5.3). A comparação entre os valores acumulados de acordo com os métodos de distribuição da chuva é apresentada na Figura 87. 

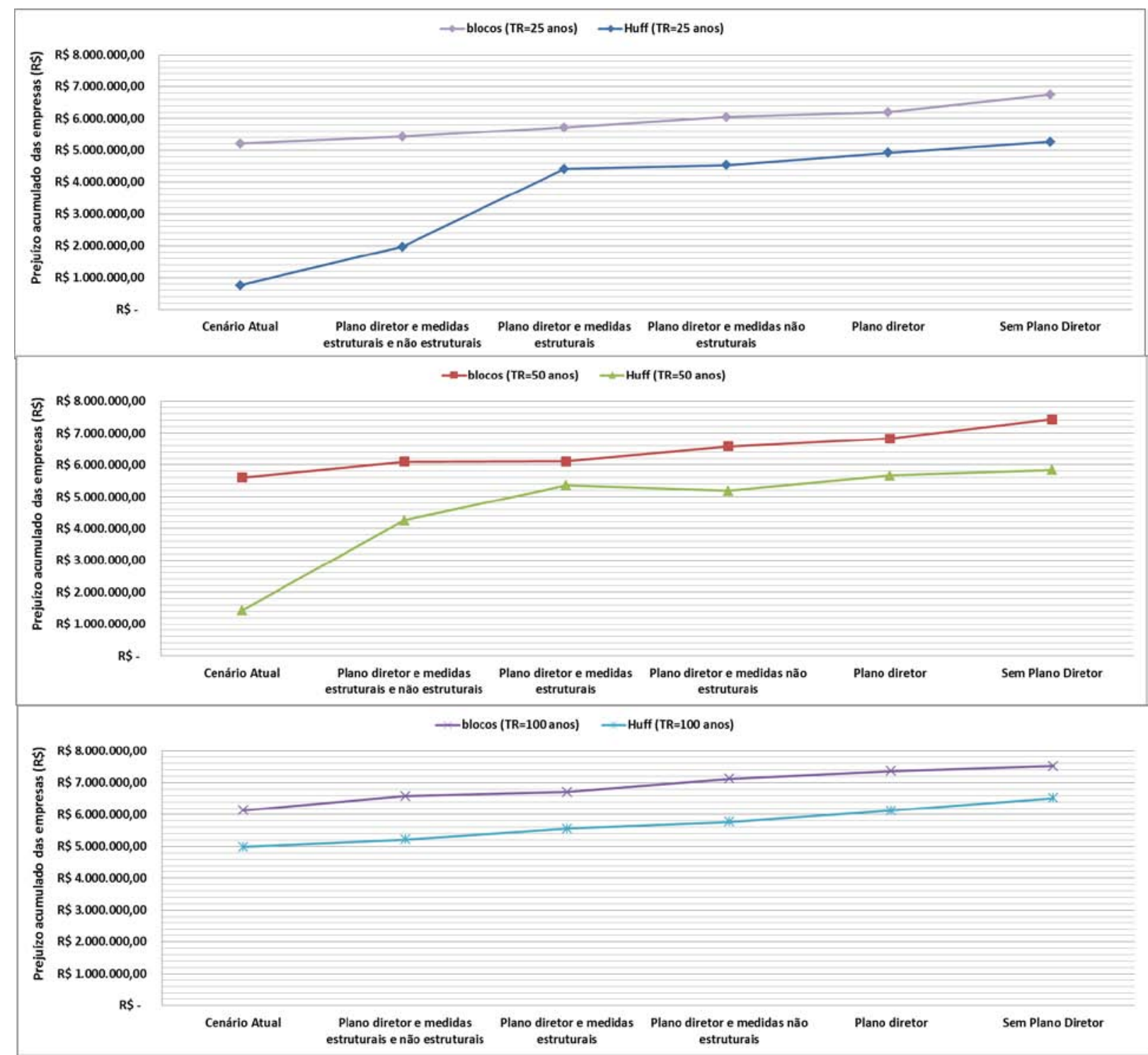

Figura 87 - Comparação entre os prejuízos acumulados das empresas pelos métodos de distribuição temporal das chuvas blocos alternados e Huff $1^{\circ}$ quartil

Partindo da hipótese de que 76\% das precipitações na bacia do Gregório encontramse situadas entre o $1^{\circ}$ e o $2^{\circ}$ quartil (Vasconcelos, 2007) assim como as chuvas de projeto neste estudo, foram apresentadas curvas com os intervalos de prejuízos passíveis de ocorrer entre esses quartis para os TR de 25, 50 e 100 anos (Figura 88).

Assim, é possível concluir que, os prejuízos acumulados no cenário atual para TR de 25 anos situam-se entre R 750.000,00 e R\$ 5.200.000,00, os prejuízos para TR de 50 anos entre 1.400.000,00 e R \$ 5.600.000,00 os para TR de 100 anos entre e R \$ 5.000.000,00 e R \$ 6.100.000,00, os quais englobam o conjunto possível de configurações de distribuição temporal das chuvas para cada TR em 76\% dos eventos de precipitação. Ressalta-se a grande variação existente entre os cenários de menor tempo de retorno (TR 25 e 50 anos) para o cenário atual. 
Para os cenário 5 (Plano diretos e medidas estruturais e não estruturais), os prejuízos acumulados para TR de 25 anos situam-se entre R\$ 1.900.000,00 e R\$ 5.400.000,00, os prejuízos para TR de 50 anos entre R\$ 4.200.000,00 e R\$ 6.100.000,00 e para TR de 100 anos entre R\$5.200.000,00 e R \$ 6.600.000,00.

Para os demais cenários futuros, os prejuízos situaram-se entre R \$ 4.400.000,00 e R\$ 7.500.000,00 entre os eventos. 


\section{CONCLUSÕES E RECOMENDAÇÕES}

\subsection{Aplicação dos métodos de distribuição temporal para analise dos hidrogramas de cheia}

A análise dos hidrogramas de cheia pelo método dos blocos alternados e Huff $1^{\circ}$ quartil mostraram significativas diferenças nas análises da vazão máxima obtida em cada evento. Através da modelagem hidráulico-hidrológica, foi possível realizar comparações entre os métodos.

Nesta análise foi possível constatar aumentos entre 32\% e 46\% na vazão máxima para o método dos blocos alternados em relação ao método de Huff $1^{\circ}$ quartil, o que gerou entre $16 \%$ e $56 \%$ de aumento de área da mancha de inundação e entre 15\% a 62\%nos incrementos porcentuais da profundidade de submersão em que se encontram os imóveis contidos na mancha de inundação.

Foi possível verificar pelos hidrogramas gerados pelo software HEC-HMS (Figura 35 e 36) que tais discrepâncias são geradas pela maior perda (precipitation loss) decorrentes de infiltração e de perdas inicias pelo método dos blocos alternados. Dessa forma, uma análise profunda sobre as características da distribuição temporal das precipitações deve ser avaliada antes de gerar manchas de inundação, tendo em vista a alta sensibilidade que a distribuição temporal das precipitações gerou nos resultados.

Observou-se que vazões de pico com tempo de retorno de 25 anos para os blocos alternados são semelhantes aos obtidos para o mesmo cenário com tempo de retorno de 100 anos pelo método de Huff em todos os cenários, fato que evidencia a grande sensibilidade do modelo chuva-vazão quanto ao método de distribuição de chuva.

\subsection{Obtenção das manchas de inundação pelos métodos de distribuição temporais de chuvas aplicados por meio de SIG}

As manchas de inundação foram obtidas com a utilização do HecGeoRas, suplemento do ArcGIS, e demonstraram a grande variação existente entre as áreas de abrangência com a utilização de distribuição temporais de chuva distintas. As manchas foram importantes para delimitar espacialmente as empresas contidas na mancha de inundação. 
As diferenças nos métodos de distribuição das chuvas influenciam diretamente nas áreas da mancha de inundação Essa diferença mostra a grande sensibilidade do método com relação ao $\mathrm{CN}$, tendo em vista que o valor de CN pode influenciar nessa diferença.

Percebeu-se que os cenários de maior impacto hidrológico, ou seja, com maiores vazões de cheia, tendem a produzir menores variações de áreas de inundação em função dos métodos de distribuição temporal da tormenta estudados. Esse tipo de efeito tende a ser menor quanto maior for a área impermeável da bacia, uma vez que para esses casos a precipitação efetiva é praticamente igual ao total precipitado.

\subsection{Cadastramento dos imóveis residenciais e comerciais presentes na mancha de inundação e banco de dados em plataforma SIG}

O cadastramento dos imóveis foi uma ferramenta importante na análise das variáveis econômicas dos imóveis contidos na mancha de inundação. Através da incorporação dos imóveis em um Sistema de Informações Geográfica (SIG) com dados de altura de submersão, foi possível exportar os valores gerados na mancha de inundação e atrelar as informações a Identificadores (ID) vinculados a cada imóvel de forma automática através da ferramenta Spacial analyst.

Devido à automatização e da análise por esse suplemento, foi possível realizar a análise de um grande número de identificadores, gerando um banco de dados extenso contido em 72 planilhas, relacionadas a cada evento de inundação pelos métodos de Huff $1^{\circ}$ quartil e blocos alternados para os imóveis residenciais e comerciais. As informações utilizadas para o banco de dados gerado estão contidas nos Apêndices B e C.

\subsection{Obtenção das profundidades de submersão dos imóveis cadastrados sob as duas formas de distribuição temporal das chuvas em diferentes cenários e tempo de retorno}

As profundidades de submersão de cada imóvel foram dados importantes para a quantificação dos prejuízos de decorrentes das inundações. Assim, foi possível correlacionar a altura de inundação em que o imóvel está inserido com o prejuízo ocasionado, para formar a curva de danos por profundidade de submersão (DPS) através de curvas por tipo de atividade propostas por Milograna (2009). 


\subsection{Quantificação dos prejuízos nos imóveis decorrentes das profundidades de submersão para diferentes cenários e métodos de distribuição de chuvas}

Os resultados econômicos para a chuva sob o padrão de rearranjo dos blocos alternados resultaram em um considerável montante de prejuízo já para o TR de 25 para os imóveis comerciais, os quais se aproximaram dos resultados produzidos pelo Huff para períodos de retorno de 100 anos. Essa relação sugere que, para a valoração econômica, a mensuração dos prejuízos decorrentes de inundações na bacia em estudo é próximo ao máximo já em períodos de retorno de 25 anos pelo método dos blocos alternados.

Ao aplicar o estudo econômico para uma chuva de 25 anos de tempo de retorno no cenário atual, verificou-se que 112 das 122 empresas que compõem o prejuízo máximo já se encontravam a mercê de danos provocados por inundações, de modo que 88 dessas encontravam-se em altura de submersão maior do que 1,2 m que, de acordo com o $I A_{M 2}$, alcança prejuízos superiores a 94\% de perdas do conteúdo.

A análise econômica através do uso de curvas de prejuízo por profundidade de submersão é sensível a alterações de profundidade. Dessa forma, a aferição do modelo hidrológico com dados observados é de suma importância face às discrepâncias que podem ocorrer entre as simulações geradas. Assim, é ainda bastante prematura a assertiva quanto aos valores obtidos pelas simulações, geradas pelo grande número de incertezas a que está submetido o modelo hidráulico-hidrológico, já que a análise hidrológica demonstrou a grande variabilidade dos resultados econômicos quanto a distribuição temporal, demonstrando que tais valores podem ser extremamente discrepantes, principalmente em razão do grau de impermeabilização da superfície do solo.

A distribuição temporal das chuvas demonstrou grande variabilidade entre os métodos quanto ao prejuízo total, alcançando valores 7 vezes maior para o TR de 25 anos no cenários atual entre os dois métodos ( $\mathrm{R}$ \$750.000,00 para Huff $1^{\circ}$ quartil e R \$ 5.200.000,00 para blocos alternados).

Com relação aos cenários, as medidas não estruturais (inseridas no cenário 4) se equipararam ao das medidas de intervenção com a construção de obras de detenção de águas pluviais (cenário 3), ou seja, a construção de barragens de acumulação de água pluvial se equipara ao adequado disciplinamento do uso do solo.

Além disso, as simulações sugerem que as medidas propostas pelo plano diretor de São Carlos não serão suficientes para conter o aumento das vazões nas regiões não urbanizadas e em processo de urbanização na contenção de enchentes, já que os prejuízos 
obtidos para esse cenário modelado (cenário 2 - plano diretor) aproximaram-se daqueles obtidos para o cenário em que não houve qualquer intervenção do município, cenário em que foi aplicado o padrão da zona urbanizada atual da bacia do Gregório para as áreas em processo de urbanização (cenário 6).

Por fim, o estudo mostrou que a diferenças obtidas pelos métodos de distribuição temporal trouxeram variações mais significativas do que aquelas obtidas pelos cenários simulados, demonstrando a maior sensibilidade da distribuição temporal frente aos cenários futuros.

Ou seja, é importante ressaltar que a questão da distribuição temporal da tormenta de projeto é fundamental para se obtiver resultados confiáveis sobre os efeitos das inundações em bacias urbanas, principalmente naquelas que apresentam parcelas significativas de áreas permeáveis.

\subsection{Analisar as diferenças nos resultados obtidos em função dos três fatores influentes: distribuição temporal das tormentas de projetos, cenários de ocupação e períodos de retorno}

A comparação entre os porcentuais de aumento de vazão para os dois métodos relacionados com o valor de $\mathrm{CN}$ mostraram que, quanto menor o valor de $\mathrm{CN}$, maiores são as diferenças no incremento de vazão de um método para o outro.

Assim, conclui-se que a alteração do método de distribuição temporal das chuvas pode trazer incertezas quanto à transformação da chuva em vazão e, dessa forma, introduzir diferenças significativas nos resultados. Porém, é possível perceber que essas diferenças possuem correlação direta com o valor de CN obtido para a bacia, de modo a estabelecer tendências quanto a essa variável, tendo em vista que um menor valor de CN gerou maiores discrepâncias entre os métodos em comparação aos cenários para o mesmo TR. 


\section{Recomendações}

Desta forma, são sugeridas as seguintes recomendações para trabalhos futuros:

$\checkmark \quad$ Realizar levantamento por entrevistas nos imóveis residenciais e comerciais afim de avaliar os danos sofridos pelas inundações em decorrência das alturas de submersão a que os imóveis podem estar expostos para a elaboração de curva de danos por profundidade de submersão na mesma área de estudo desta pesquisa;

Ampliar a quantificação dos danos causados pelas inundações, incluindo prejuízos econômicos indiretos, problemas de saúde pública e qualidade de vida, danos ambientais, etc. $\checkmark \quad$ Elaborar simulações pelo método de Huff para o $1^{\circ}, 2^{\circ}$ e $3^{\circ}$ quartis com $10 \%$, $50 \%$ e 90\% de probabilidade de ocorrência para análise das variações estatisticamente mais prováveis da área, vazão e profundidade de submersão da mancha de inundação.

Realizar estudo da distribuição temporal das chuvas intensas na bacia do Córrego do Gregório próximo ao mercado municipal para categorizar as precipitações de acordo com o método proposto por Huff, para a criação de diretrizes quanto à distribuição temporal das precipitações a serem utilizadas em chuvas de projeto utilizadas nesta região.

$\checkmark \quad$ Avaliar a influência de outros parâmetros e fatores na geração de hidrogramas, manchas de inundação e prejuízos, tais como: diferentes tipos de modelos chuva-vazão, tempos de concentração, duração da chuva crítica, distribuição espacial da chuva crítica, uso de imagens de satélite com resoluções espaciais distintas, critérios alternativos de valoração econômica, etc. 


\section{REFERÊNCIAS}

ABEP - Associação Brasileira de Empresas de Pesquisa. Critério de Classificação Econômica Brasil, 2009. Disponível em <www.abep.org $>$.

ALMEIDA, V. A., NASCIMENTO, N., BAPTISTA, M. Avaliação da eficiência de sistemas alternativos de drenagem urbana de águas pluviais. In: VI Encontro Nacional de Águas Urbanas CREA-MG - Belo Horizonte, 18 a 20 de maio de 2005.

ANGELINI SOBRINHA, L. Monitoramento e modelagem de um poço de infiltração de águas pluviais em escala real e com filtro na tampa. 148 p. (Dissertação de Mestrado em Engenharia Urbana). Universidade Federal de São Carlos. São Carlos - SP, 2012.

ARANTES, J. T. Prejuízo ao país com enchentes em São Paulo ultrapassa R\$ 762 milhões por ano. AGÊNCIA FAPESP. Disponível em: <http://agencia.fapesp.br/16968> Acesso em 05/08/2013

ARNELL, V. Rainfall data for design sewer detention basins. Chamels University of Technology, Urban Geohydrology Reserch Group, Göteborg, 1984.

BAPTISTA, M. B.; NASCIMENTO, N.O. ; BARRAUD, S.. Técnicas compensatórias em Drenagem Urbana, Porto Alegre: ABRH, $1^{\circ}$ ed. 266p. 2005.

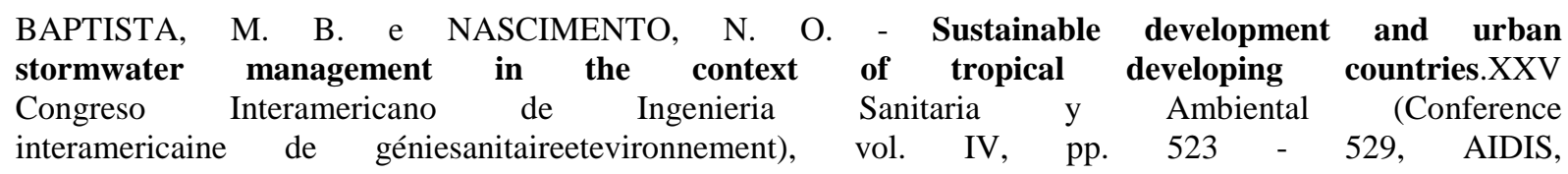
México - 1996

BARBASSA, A. P. Simulação do efeito da urbanização sobre a drenagem pluvial na cidade de São Carlos/SP. 1991. 327 f. Tese (Doutorado em Hidráulica e Saneamento) - Escola de Engenharia de São Carlos, Universidade de São Paulo, São Carlos, 1991.

BARRAUD, S.; AZZOUT, A.; CRES, F. N.; CHOCAT, B. Selection aid of alternative techniques in urban storm drainage - Proposition of an expert system. Water Science and Technology, v. 39, n.4, 1999.

BARRoS, R. M. Previsão de Enchentes para o Plano Diretor de Drenagem Urbana de São Carlos (PDDUSC) na Bacia Escola do Córrego do Gregório. 2005. 279 f. Tese (Doutorado em Hidráulica e Saneamento) - Escola de Engenharia de São Carlos, Universidade de São Paulo, São Carlos, 2005.

BENJAMIN, A. H. V. Responsabilidade civil pelo dano ambiental. Revista de Direito Ambiental. RDA 9/5, março de 1998.

BRAGA, R. Plano Diretor Municipal: Três Questões para Discussão. In: Caderno do Departamento de Planejamento. Faculdade de Ciências e Tecnologia - UNESP - Presidente Prudente, vol. 1, n. 1, 1995.

BRANDÃO, C.; RODRIGUES, R.; COSTA, J. P. - Análise de fenómenos extremos precipitações intensas em Portugal continental - Direç̧ão dos Serviços de Recursos Hídricos - Lisboa - 2001

BRASIL. Medida Provisória no 2.166-67, de 24 de agosto de 2001. Altera os arts. $1^{\circ}, 4^{\circ}, 14,16$ e 44, e acresce dispositivos à Lei no 4.771, de 15 de setembro de 1965, que institui o Código Florestal, bem como altera o art. 10 da Lei no 9.393, de 19 de dezembro de 1996, que dispõe sobre o Imposto sobre a Propriedade Territorial Rural - ITR, e dá outras providências. Diário Oficial da União, Brasília, DF, 24 Ago. 2001.

BRASIL. Constituição Federal - 1988

BRASIL. Estatuto da Cidade. Lei 10.257 de 2001 
BENINI, R. M. Cenários de ocupação urbana e seus impactos no ciclo hidrológico na bacia do Córrego do Mineirinho. 2005. 122 f. Dissertação de Mestrado (Ciências da Engenharia Ambiental) - Programa de PósGraduação em Ciências da Engenharia Ambiental. Escola de Engenharia de São Carlos da Universidade de São Paulo, São Carlos, 2005.

BUTLER, D.; DAVIES, J. W. Urban Drainage. Londres: St Edmundsbury Press., 489 p., 2000.

CANÇADO, V. Consequências Econômicas das Inundações e Vulnerabilidade- Desenvolvimento de Metodologia para avaliação do Impacto nos Domicílios e na Cidade. MG. 2009. 1 v. Tese - (Área de concentração: recursos hídricos) - Escola de Engenharia, Universidade Federal de Minas Gerais, Belo Horizonte. 2009

CANÇADO, V. et. al. Consequências Econômicas das Inundações: Modelando o Impacto em Áreas Urbanas - XIX Simpósio Brasileiro de Recursos Hídricos - Maceió/AL - 2011.

CANHOLI, A. P. Drenagem Urbana e Controle de Enchentes. São Paulo: Oficina de textos, 302 p. 2005.

CARVALHO, E. T. L. Avaliação de elementos de infiltração de águas pluviais na zona norte da cidade de Goiânia. (Dissertação de Mestrado em Geotecnia). Universidade Federal de Goiás, Goiânia, 2008.

CHOW, V. T.. Applied Hydrology. Mc-Graw-Hill Book. 1988.

COLLODEL, M. G. Aplicação do modelo hidrológico SWMM na avaliação de diferentes níveis de detalhamento da bacia hidrográfica submetida ao processo de transformação chuva-vazão. 2009. 219 f. Dissertação (Mestrado em Hidráulica e Saneamento) - Escola de Engenharia de São Carlos, Universidade de São Paulo, São Carlos, 2009.

CRUZ, M. A. S.; TUCCI, C. E. M.; SILVEIRA, A. L. L. Controle do escoamento com detenção em lotes urbanos. In: Revista Brasileira de Recursos Hídricos - RBRH, v. 3, n. 4, 1998.

DAYWATER. Report 5.1. Review of the use of stormwater BMPs in Europe. Disponível em: $<$ www.daywater.org> 98p. 2003.

DECHESNE, M. Connaissance et modélisation du fonctionnement des bassins d'infiltration d'eaux de ruissellement urbain pour l'évaluation des performances technique et environnement alesur le long terme. Thése. INSA de Lyon. Lyon, França. 275p. 2002.

DECINA, T. G. T. - Avaliação de medidas de controle de inundações na bacia hidrográfica do Córrego do Gregório, São Carlos, SP - Dissertação - Escola de Engenharia de São Carlos - EESC/USP - Maio 2012.

DERANI, Cristiane. Direito Ambiental Econômico. São Paulo: Max Limonad. p. 120. 1997

EPA, 2011.EPA Announces Guidance on State Revolving Funds for Sewage Treatment. Disponível em: <http://www.epa.gov/aboutepa/history/topics/cwa/02.html>. Acesso em 23 set. 2011.

FARIA, R.C., Nogueira, J.M. Método de valoração contingente: aspectos teóricos e empíricos. Brasília, 1998.

GAROTTI, L. M.; IMOTO, T. S.; BARBASSA, A. P. Uso da área impermeabilizada diretamente conectada como base para estimação do coeficiente de escoamento superficial e comparação com outras estimativas. In: XVII SIMPÓSIO BRASILEIRO DE RECURSOS HÍDRICOS. Anais. São Paulo, 2007.

GOERL, R.F.; KOBIYAMA, M. (2005). Considerações sobre as inundações no Brasil. XVI Simpósio Brasileiro de Recursos Hídricos - Associação Brasileira de Recursos Hídricos. João Pessoa - PB.

GRACIOSA, M.C.P. Modelo de seguro para riscos hidrológicos com base em simulação hidráulicohidrológica como ferramenta de gestão do risco de inundações. 2010. 163 f. Tese (Doutorado em Engenharia Civil, Área de concentração: Hidráulica e Saneamento) - Escola de Engenharia de São Carlos, Universidade de São Paulo, São Carlos, 2010. 
HANLEY, N.; SPASH, C. L. Cost-benefit analysis and the environment. Hants, Inglaterra: Edward Elgar. 278p.1993

HEC-HMS. (2002). River Analysis System - User's Manual(version 3.1.3).(2002). U.S. Army Corps of Engineers, Hydrologic Engineering Center.482 p. Maio 2003

HEC-RAS. (2003). Hydrologic Modeling System - User's Manual (version 2.1.2).(2003). U.S. Army Corps of Engineers, Hydrologic Engineering Center, Davis. 482 p.Maio2003

HUFF, F. A., Time distribution of rainfall in heavy storms. Water Resources Research, v.3, n.4, p. 10071019. 1967.

INSTITUTO BRASILEIRO DE GEOGRAFIA E ESTATÍSTICA - IBGE - Base de informações do Censo Demográfico 2010: Resultados do Universo por setor censitário - Documentação do Arquivo - Rio de Janeiro $-2011$.

INSTITUTO BRASILEIRO DE GEOGRAFIA E ESTATÍSTICA - IBGE - Pesquisa anual do comércio - Rio de Janeiro, v. 21, p.153, 2009.

INSTITUTO BRASILEIRO DE GEOGRAFIA E ESTATÍSTICA - IBGE Notas Técnicas do Cadastro Central de Empresas - CEMPRE. Disponível em: www.ibge.gov.br.- 2005.

INSTITUTO BRASILEIRO DE GEOGRAFIA E ESTATÍSTICA - IBGE. Estudos e Pesquisas Informação Demográfica e Socioeconômica.In: Tendências demográficas: Uma análise dos resultados da sinopse preliminar do censo demográfico 2000. Rio de Janeiro, 2001.

LEZCANO, L. M., Análise do Efeito do Risco de Cheia no Valor de Imóveis pelo Método dos Preços Hedônicos. Dissertação de M.Sc., Curso de Pós-Graduação em Engenharia de Recursos Hídricos e Ambiental Universidade Federal do Paraná, Curitiba, PR, Brasil - 2004

MACHADO, M. L. Curvas de Inundação versus profundidade de submersão: Desenvolvimento de Metodologia - Estudo de caso da Bacia do Rio Sapucaí, Itajubá - MG - Tese - Universidade Federal de Minas Gerais - Belo Horizonte/MG- 2005

MARTINS, L. G. B. Determinação de parâmetros hidrológicos por técnicas de sensoriamento remoto em macrodrenagem urbana. Dissertação (Mestrado) - Escola de Engenharia de São Carlos, Universidade de São Paulo. 107p. 2012

MARTINE, G. A redistribuição especial da população brasileira durante a década de 80. Instituto de Pesquisa Econômica Aplicada.Ed. BNDES, 1994.

MATOS, M. R. S. Gestão integrada de águas pluviais em meio urbano: visão estratégica e soluções para o futuro. Teses e Programas de Investigação LNEC. Laboratório Nacional de Engenharia Civil - LNEC. Lisboa, Portugal, 2000.

MENDES, H. C.; MENDIONDO, E. M. Histórico da Expansão Urbana e Incidência de Inundações: o caso da Bacia do Gregório, São Carlos - SP. RBRH — Revista Brasileira de Recursos Hídricos. Volume 12 n.1, 1727.Jan/Mar 2007

MILOGRANA, J. Sistemática de Auxílio à decisão para a seleção de alternativas de Controle de inundação urbanas. Tese de doutorado em tecnologia ambiental e recursos hídricos, Publicação PTARH. TD - 05/09, Departamento de engenharia civil e ambiental, Universidade de Brasília, DF, 316p. 2009. 
MINISTÉRIO DAS CIDADES - Manual para apresentação de Propostas para sistemas de Drenagem urbana sustentável e de Manejo de águas pluviais - Secretaria nacional de saneamento ambiental - Brasília 2012.

MOTTA, R. S. Manual para valoração econômica de recursos ambientais. Brasília: Ministério do Meio Ambiente, dos Recursos Hídricos e da Amazônia Legal, 1997.

PMSC - Prefeitura Municipal de São Carlos. Conferência da cidade: Diagnóstico para elaboração do Plano Diretor de São Carlos, 2003. CD-ROM.

PMSC - Prefeitura Municipal de São Carlos. Lei $\mathbf{n}^{\mathbf{0}}$ 13.691, de 25 de novembro de 2005. Disponível em: http://www.saocarlos.sp.gov.br/images/stories/pdf/Lei_13691_05_Plano_Diretor.pdf

PMSC - Prefeitura Municipal de São Carlos. Secretaria Municipal de Obras. SHS Consultoria e Projetos de Engenharia S/S Ltda. Plano Diretor de Drenagem Urbana Ambientalmente Sustentável. São Carlos: 2011. 213 p. Relatório Síntese. Volume II -Medidas Estruturais,Medidas Não Estruturais e Custos. Contrato nº 87/09 Processo $n^{\circ}$ 6.965/07. 2011

PORTO, R. L. L. Escoamento superficial direto. In: BARROS, M. T.; PORTO, R.L; TUCCI, C. E. M (Organizadores). Drenagem urbana. Cap. 4, p.107-165.Porto Alegre: ABRH, 1995

PRINCE GEORGE'S. Low Impact development design strategies: an integrated design approach. Prince George’s: Department of Environmental Resource. Programs and Planning Division, 150 p. 1999.

REIS, R. P. A; OLIVEIRA, L. H.; SALES, M. M. Sistemas de drenagem na fonte por poços de infiltração de água pluvial. In: Ambiente Construído, Porto Alegre, v. 8, n. 2, p. 99-117, abr./jun. 2008.

RIBEIRO, G. Acerca do cálculo da vazão de obras d'arte: tempo de concentração. Revista do Clube de Engenharia. Rio de Janeiro, n.291, p.16-19, 1961

RIGHETTO, J. M.; MENDIONDO, E. M. Avaliação de riscos hidrológicos: principais danos e causas e proposta de seguro contra enchentes. In: III SIMPÓSIO DE RECURSOS HÍDRICOS CENTRO-OESTE, 2004, Goiânia. Anais. Goiânia, 2004.

ROMEIRO, A R. Economia ou economia política da sustentabilidade? -Texto para Discussão. IE/UNICAMP, Campinas, n. 102, set. 2001.

SÃO PAULO. Secretaria Municipal de Desenvolvimento Urbano. Manual de Drenagem e Manejo de Águas Pluviais: Aspectos tecnológicos; diretrizes para projetos. 130p.São Paulo: SMDU, 2012

SCHMIDT, B.; FARRET, R.A questão urbana. Ed. Jorge Zahar: Rio de Janeiro, 1986.

SHUELER, T. R. Controlling urban runoff: A practical manual for planning and designing urban BMPs. Department of Environmental Programs. Washington Metropolitan Water Resources Planning Board. 1987.

SIGA - SC. Sistemas de Informações Geográficas de São Carlos. Disponível em: <http://geo.saocarlos.sp.gov.br>. Acesso em janeiro de 2013.

SILVA, E. R. Um percurso na história através da água: passado, presente, futuro. In: XXVII Congresso Interamericano De Engenharia Sanitária E Ambiental.v. 1. Rio de Janeiro: ABES, 2000.

SILVEIRA, A. L. L. Hidrologia Urbana no Brasil. In: Braga, B.; Tucci, C. E. M.; Tozzi, M., 1998, Drenagem Urbana, Gerenciamento, Simulação, Controle. ABRH, Publicações no 3, Editora da Universidade, Porto Alegre. 1998. 
SOUZA, R. F. P. - Economia do meio ambiente: Aspectos teóricos da economia ambiental e da economia ecológica - XLVI Congresso da Sociedade Brasileira de economia e administração e Sociologia Rural - Rio Branco - 2008.

SOUZA, V. C. B. Estudo experimental de trincheiras de infiltração no controle da geração do escoamento superficial. (Tese de Doutorado em Engenharia de Recursos Hídricos e Saneamento Ambiental). Universidade Federal do Rio Grande do Sul. Porto Alegre, 127p. + anexos, 2002.

STU ET AGENCES DE L'EAU. Guide Technique des Bassins de Retenue d'Eaux Pluviales. Technique et Documentation. Ed. Lavoisier. Paris, França. 276 p. 1994.

STU. Réconcilier l’Eau et la Ville para la Maîtrise des Eaux Pluviales. Les Editions Du STU. Paris, França. 64 p. 1991.

TESSLER, M. I. B. Valoração do dano ambiental. In: Curso de Especialização em Direito Ambiental Nacional e Internacional: Texto-base para a palestra no Curso de Direito Ambiental e do Consumidor, UFRGS/Instituto por um Planeta Verde, out. 2004.

TIETENBERG, T. Environmental and Natural Resource Economics.15ª ed. Addison-Wesley, 2000.

TUCCI, C. E. M., HESPANHOL, I. e CORDEIRO NETTO, O. M. Cenários da gestão da água no Brasil: Uma Contribuição Para a "Visão Mundial da Água". Bahia Análise e Dados, vol. 13 n. especial, 357-370 - 2003.

TUCCI, C. E. M. Inundações urbanas. In: TUCCI, C. E. M.; PORTO, R. L. L.; BARROS, M. T. Drenagem urbana. $1^{\text {a }}$ edição.cap. 1, p. 15-36.Porto Alegre: ABRH / Editora da Universidade / UFRGS, 1995

TUCCI, C. E. M. Gerenciamento da drenagem urbana. In: RBRH: Revista Brasileira de Recursos Hídricos. Porto Alegre, RS Vol. 7, n. 1(2002 jan./mar). 2002.

UNITED STATES ENVIRONMENTAL PROTECTION AGENCY (USEPA). Overview of performance by BMP category and common polluant type, In: International Stormwater Best Management Practices (BMP) Database (1999-2008), Washington, D.C. June, 2008.

URBONAS, B; STAHRE, D. Stormwater: Best management practices and detention for water quality, drainage and CSO management. Englewood Cliffs: Prentice Hall, 1993.

USACE.Basin-level digital elevation models availability and applications- The Red River of the North basin case study. IWR Report 04-R-1

USDA (U.S. DEPARTMENT OF AGRICULTURE). Urban Hydrology for Small Watersheds. Natural Resouces Conservation Service. Technical Release 55. Washington: USDA, 1986.

VASCONCELOS, A. F.; ANDRADE, J. P. M.; MENDIONDO, E. M. - Análise qualitativa de eventos de precipitação intensa na Bacia do Gregório, São Carlos - SP - Jornadas Internacionales sobre Gestión del Riesgo de Inundaciones y Deslizamientos de Laderas - Brasil - 2007

VIESSMAN JUNIOR, W.; LEWIS, G. L.; KNAPP, J. K. Infiltration. In: Introduction to Hydrology. $3^{\circ}$ ed. New York: Harper e Row, p. 55-83. 1989.

VILELla, S. M; MATTOS, A. Hidrologia Aplicada. McGraw-Hill do Brasil, 245 p. São Paulo, 1975. 


\section{APÊNDICE A}

\section{MANCHAS DE INUNDAÇÃO}

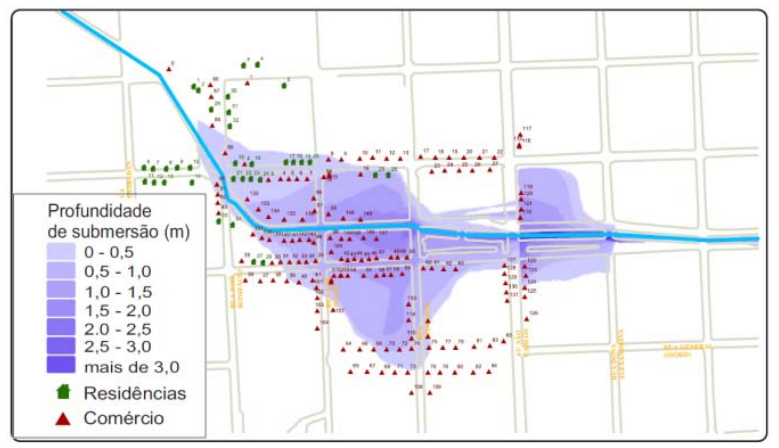

Plano Diretor com medidas estruturais e não estruturais TR $=25$ anos - Huff $1^{\circ}$ quartil

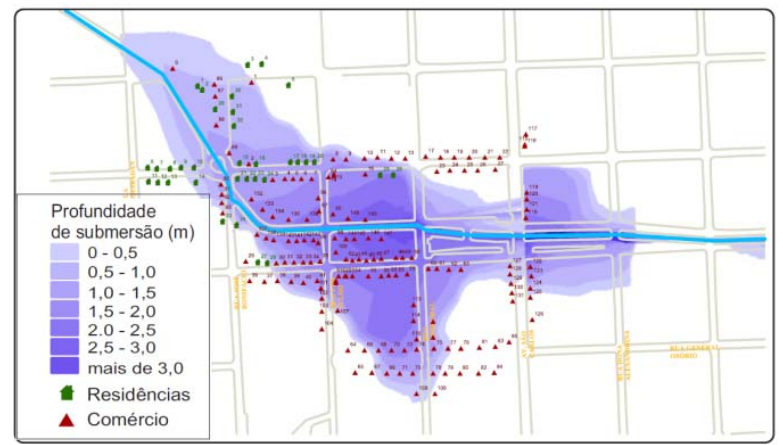

Plano Diretor com medidas estruturais e não estruturais TR $=50$ anos - Huff $1^{\circ}$ quartil

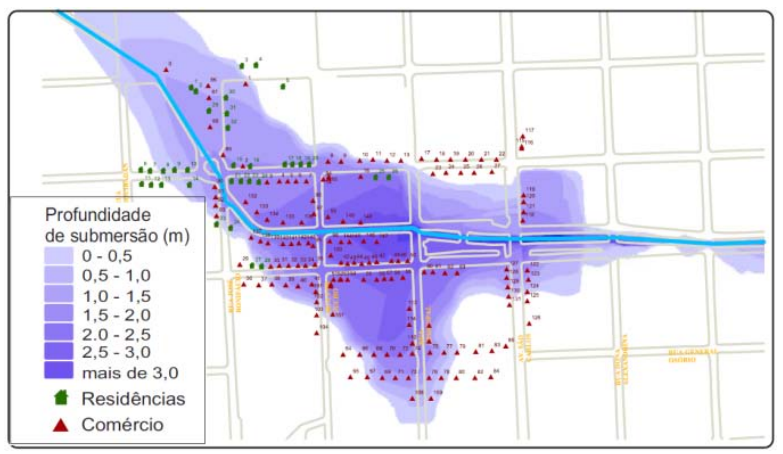

Plano Diretor com medidas estruturais e não estruturais - TR $=100$ anos - Huff $1^{\circ}$ quartil

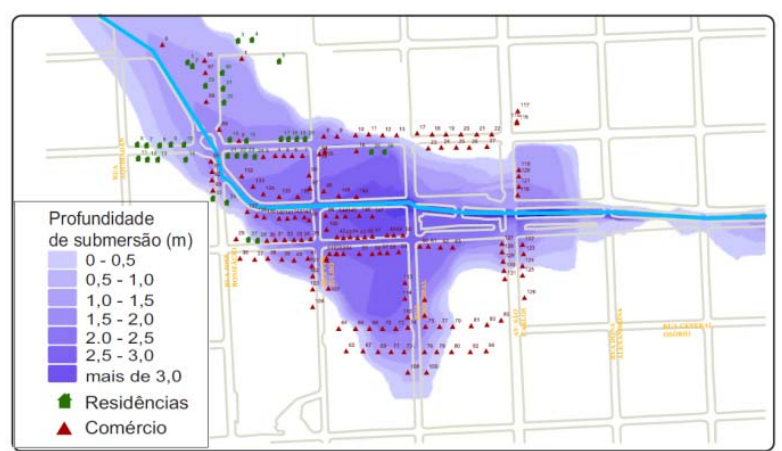

Plano Diretor com medidas estruturais e não estruturais TR $=25$ anos - Blocos alternados

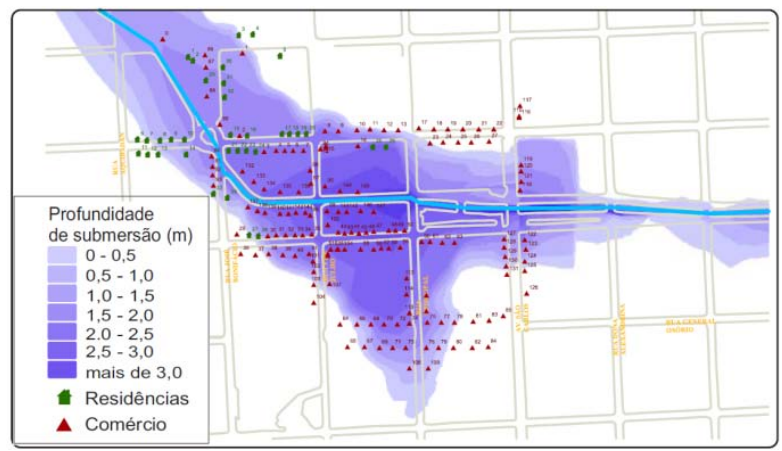

Plano Diretor com medidas estruturais e não estruturais TR $=50$ anos - Blocos alternados

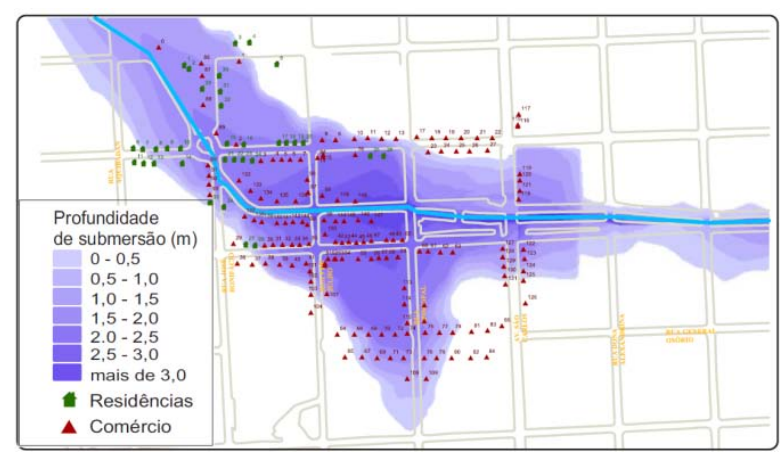

Plano Diretor com medidas estruturais e não estruturais TR $=100$ anos - Blocos alternados 


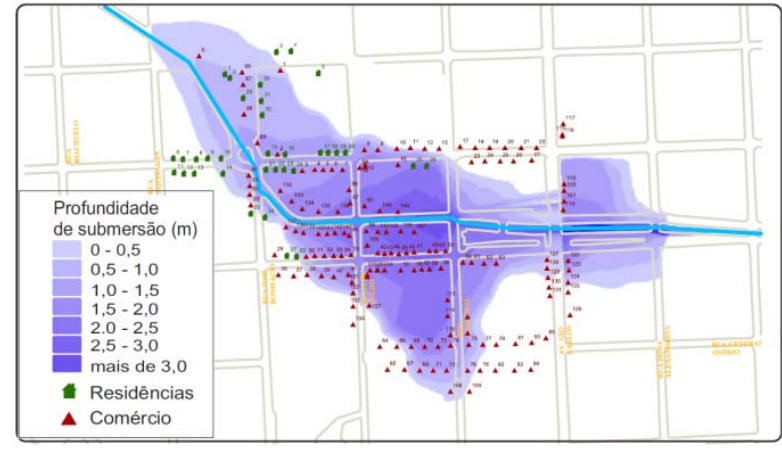

Plano Diretor com medidas estruturais TR $=25$ anos Huff $1^{\circ}$ quartil

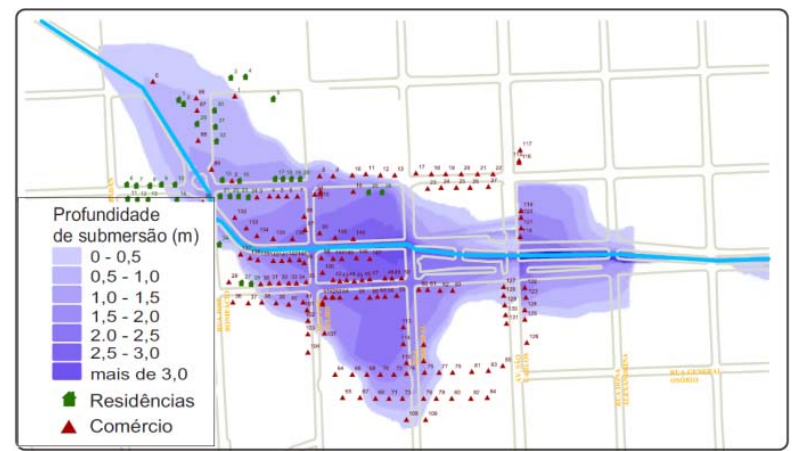

Plano Diretor com medidas estruturais $\mathrm{TR}=50$ anos Huff $1^{\circ}$ quartil

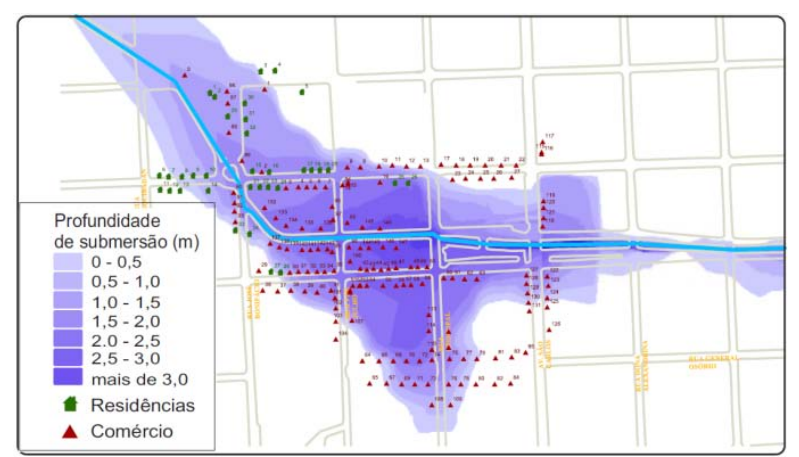

Plano Diretor com medidas estruturais $\mathrm{TR}=100$ anos Huff $1^{\circ}$ quartil

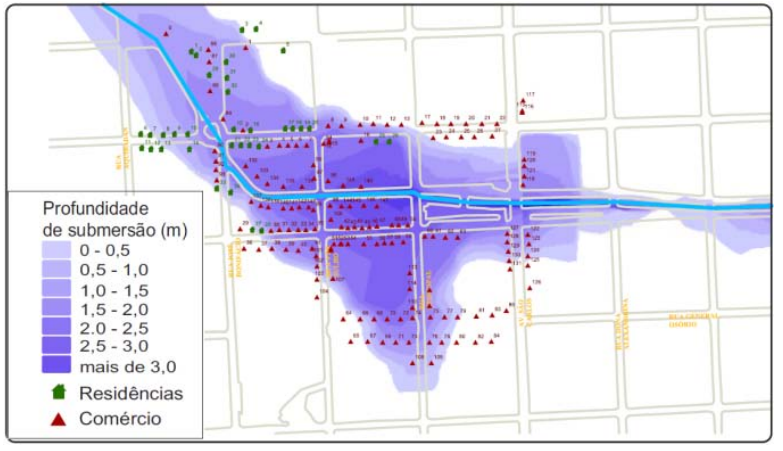

Plano Diretor com medidas estruturais $\mathrm{TR}=25$ anos Blocos alternados

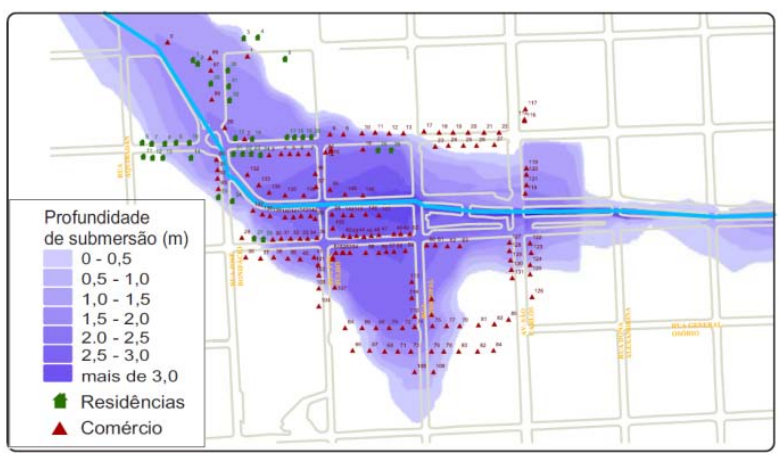

Plano Diretor com medidas estruturais TR $=50$ anos Blocos alternados

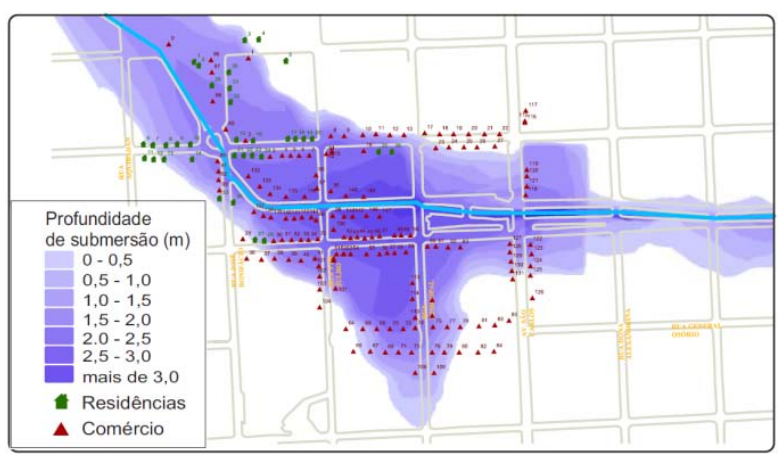

Plano Diretor com medidas estruturais TR $=100$ anos Blocos alternados 


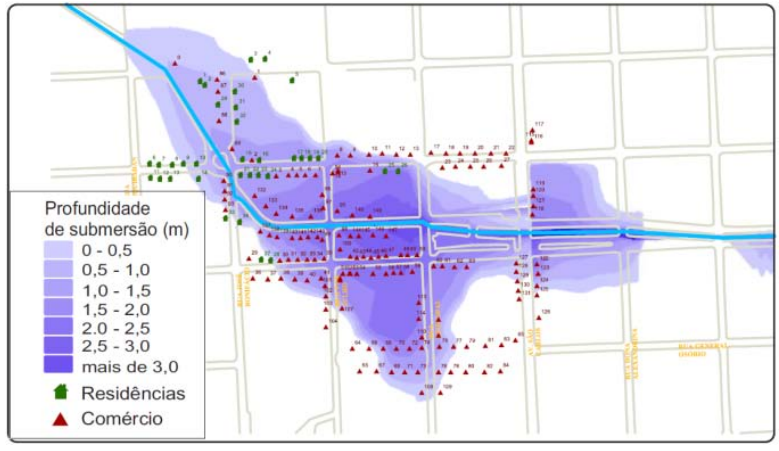

Plano Diretor com medidas não estruturais $\mathrm{TR}=25$ anos - Huff $1^{\circ}$ quartil

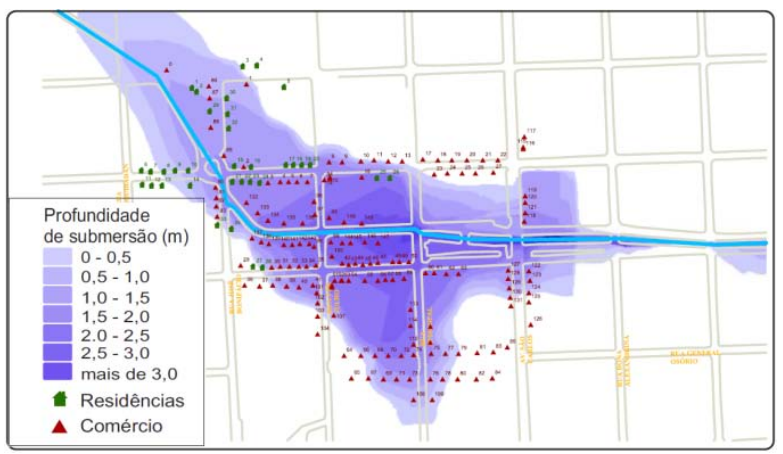

Plano Diretor com medidas não estruturais TR $=50$ anos - Huff $1^{\circ}$ quartil

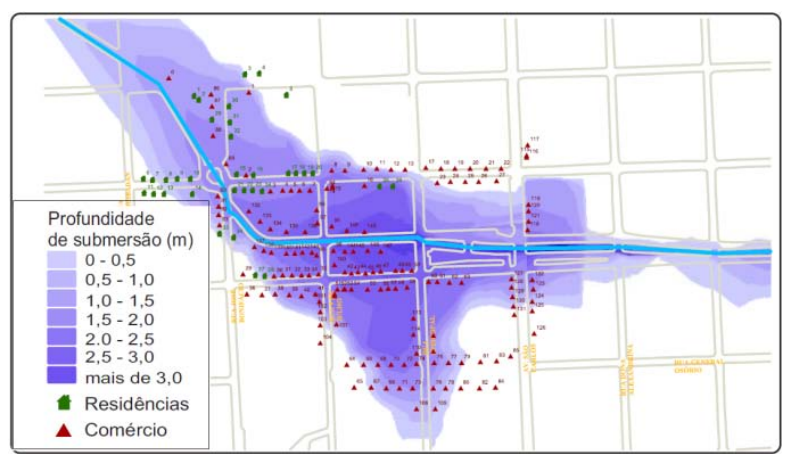

Plano Diretor com medidas não estruturais $\mathrm{TR}=100$ anos - Huff $1^{\circ}$ quartil

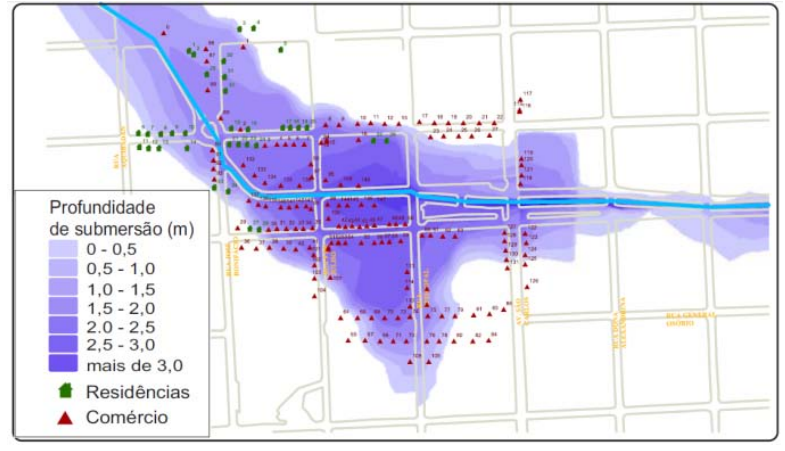

Plano Diretor com medidas não estruturais $\mathrm{TR}=25$ anos - Blocos alternados

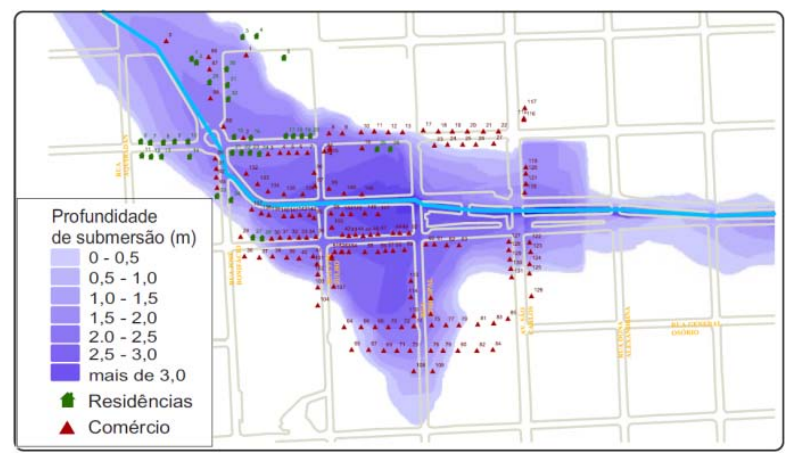

Plano Diretor com medidas não estruturais $\mathrm{TR}=50$ anos - Blocos alternados

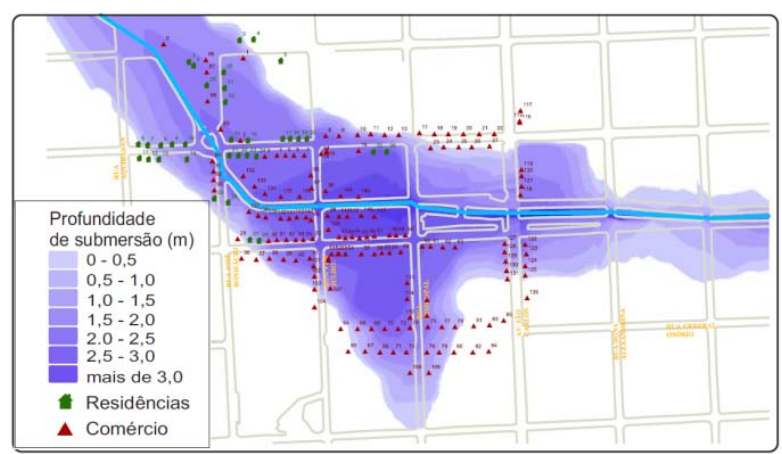

Plano Diretor com medidas não estruturais TR $=100$ anos - Blocos alternados 


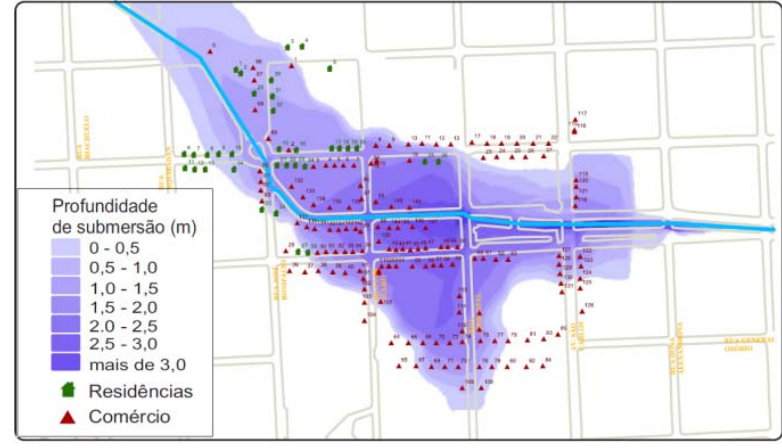

Plano Diretor - TR $=25$ anos - Huff $1^{\circ}$ quartil

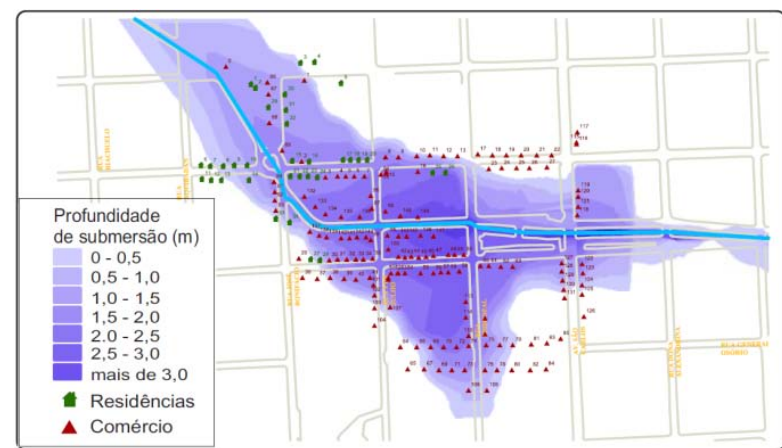

Plano Diretor $-\mathrm{TR}=50$ anos - Huff $1^{\circ}$ quartil

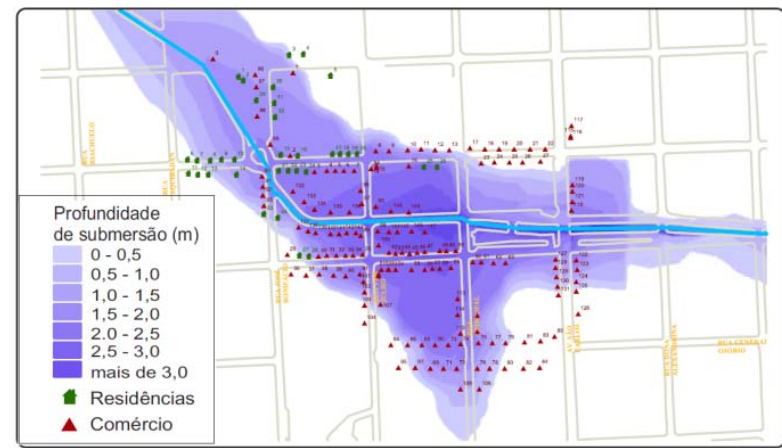

Plano Diretor TR $=100$ anos - Huff $1^{\circ}$ quartil

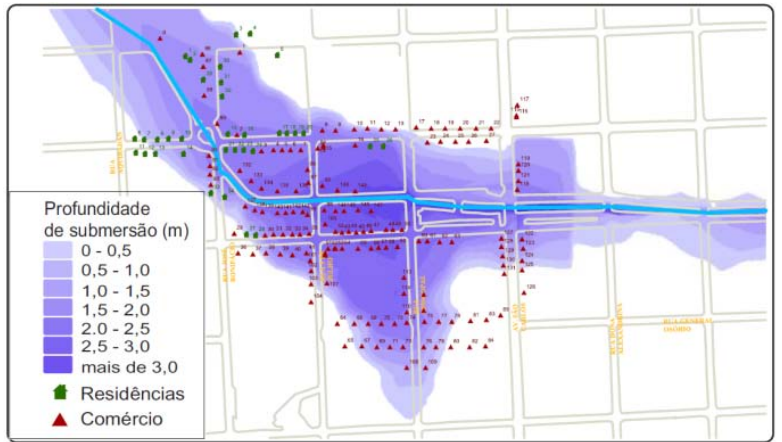

Plano Diretor - TR = 25 anos - Blocos alternados

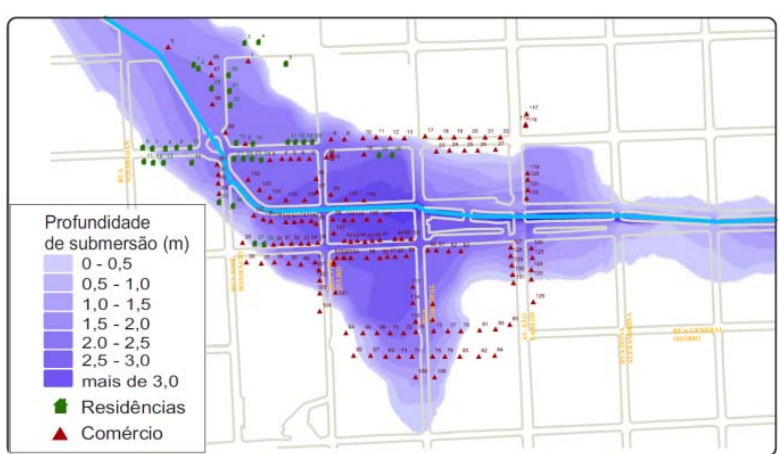

Plano Diretor $-\mathrm{TR}=50$ anos - Blocos alternados

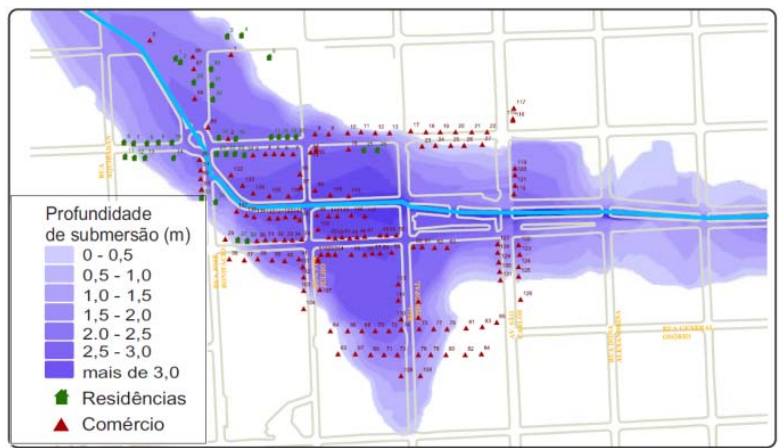

Plano Diretor $-\mathrm{TR}=100$ anos - Blocos alternados 


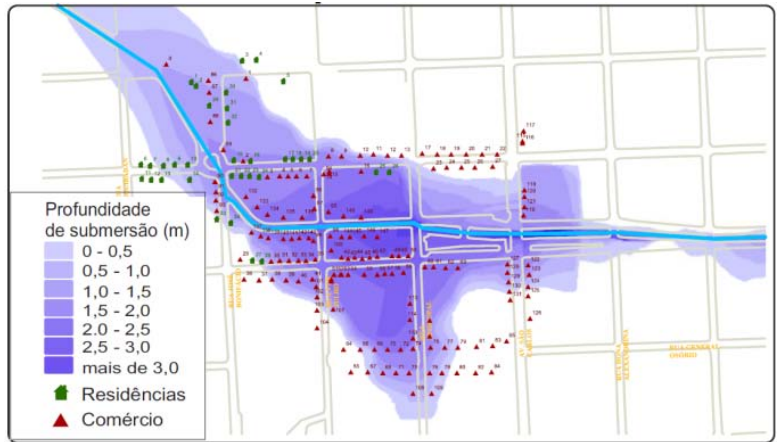

Sem Plano Diretor TR $=25$ anos - Huff $1^{\circ}$ quartil

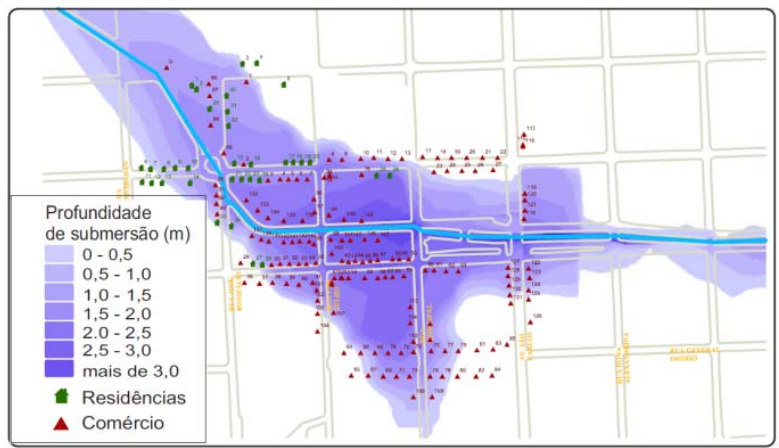

Sem Plano Diretor TR $=50$ anos - Huff $1^{\circ}$ quartil

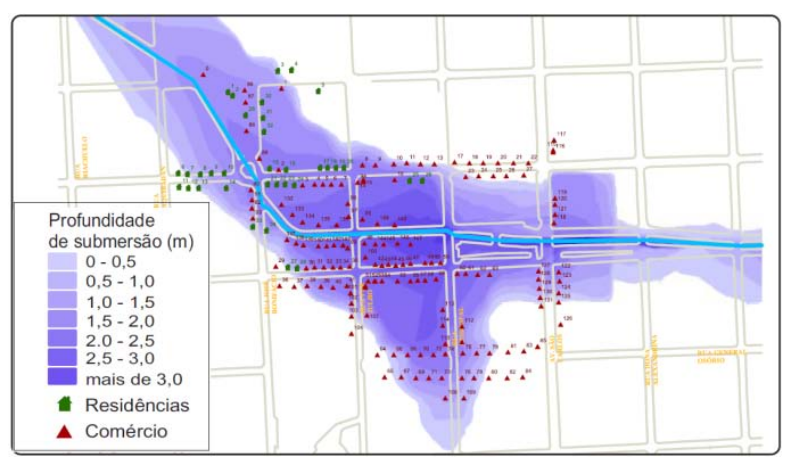

Sem Plano Diretor TR $=100$ anos - Huff $1^{\circ}$ quartil

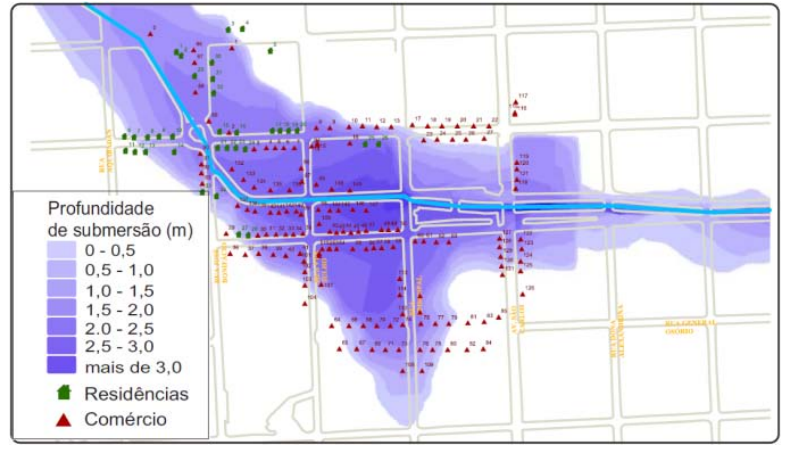

Sem Plano Diretor TR $=25$ anos - Blocos alternados

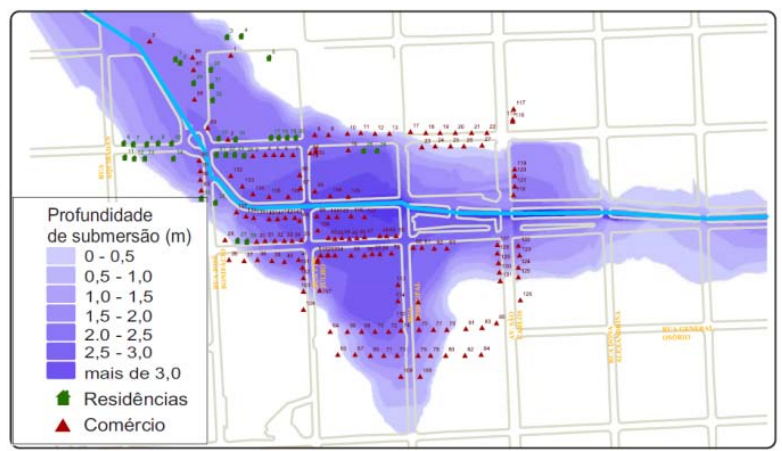

Sem Plano Diretor TR = 50 anos - Blocos alternados

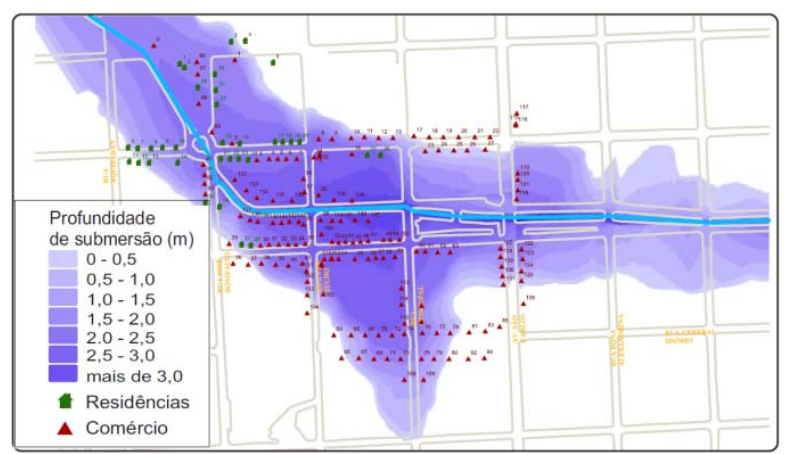

Sem Plano Diretor TR $=100$ anos - Blocos alternados 
APÊNDICE B

BANCO DE DADOS CADASTRAIS DAS RESIDÊNCIAS

\begin{tabular}{|c|c|c|c|c|}
\hline \multicolumn{2}{|c|}{$\begin{array}{c}\text { Coordenadas UTM } \\
\left(23^{\circ} \mathrm{S}\right)\end{array}$} & \multirow{2}{*}{ ID } & \multirow{2}{*}{$\begin{array}{l}\text { Tamanho } \\
\text { aparente }\end{array}$} & \multirow{2}{*}{$\begin{array}{c}\text { Classe } \\
\text { econômica }\end{array}$} \\
\hline $\mathrm{X}$ & $\mathbf{Y}$ & & & \\
\hline 201.276 & 7.562.294 & 1 & Médio & B \\
\hline 201.281 & 7.562 .290 & 2 & Médio & B \\
\hline 201.330 & 7.562.317 & 3 & Pequeno & $\mathrm{C}$ \\
\hline 201.345 & 7.562 .318 & 4 & Pequeno & C \\
\hline 201.374 & 7.562.295 & 5 & Grande & A \\
\hline 201.222 & 7.562 .206 & 6 & Médio & B \\
\hline 201.232 & 7.562.205 & 7 & Pequeno & $\mathrm{C}$ \\
\hline 201.246 & 7.562 .205 & 8 & Pequeno & C \\
\hline 201.258 & 7.562 .206 & 9 & Pequeno & $\mathrm{C}$ \\
\hline 201.272 & 7.562 .206 & 10 & Pequeno & C \\
\hline 201.223 & 7.562 .191 & 11 & Grande & A \\
\hline 201.233 & 7.562 .190 & 12 & Grande & A \\
\hline 201.244 & 7.562 .190 & 13 & Pequeno & $\mathrm{C}$ \\
\hline 201.274 & 7.562 .190 & 14 & Médio & B \\
\hline 201.321 & 7.562.211 & 15 & Médio & B \\
\hline 201.339 & 7.562 .210 & 16 & Médio & B \\
\hline 201.376 & 7.562.212 & 17 & Pequeno & C \\
\hline 201.384 & 7.562 .212 & 18 & Pequeno & C \\
\hline 201.393 & 7.562.212 & 19 & Pequeno & C \\
\hline 201.402 & 7.562 .212 & 20 & Médio & B \\
\hline 201.319 & 7.562 .194 & 21 & Pequeno & C \\
\hline 201.329 & 7.562 .194 & 22 & Grande & A \\
\hline 201.338 & 7.562 .194 & 23 & Pequeno & C \\
\hline 201.348 & 7.562 .193 & 24 & Médio & B \\
\hline 201.473 & 7.562 .198 & 25 & Médio & B \\
\hline 201.487 & 7.562.198 & 26 & Pequeno & C \\
\hline 201.341 & 7.562 .104 & 27 & Pequeno & $\mathrm{C}$ \\
\hline 201.351 & 7.562 .103 & 28 & Médio & B \\
\hline 201.295 & 7.562.269 & 29 & Grande & A \\
\hline 201.313 & 7.562 .283 & 30 & Médio & B \\
\hline 201.314 & 7.562.266 & 31 & Pequeno & $\mathrm{C}$ \\
\hline 201.315 & 7.562 .251 & 32 & Médio & B \\
\hline 201.303 & 7.562 .148 & 33 & Grande & A \\
\hline 201.318 & 7.562 .144 & 34 & Médio & B \\
\hline
\end{tabular}


APÊNDICE C

\section{BANCO DE DADOS CADASTRAIS DOS IMÓVEIS COMERCIAIS}

\begin{tabular}{|c|c|c|c|c|}
\hline \multicolumn{2}{|c|}{ Coordenadas UTM $\left(23^{\circ} \mathrm{S}\right)$} & \multirow[b]{2}{*}{ ID } & \multirow{2}{*}{$\begin{array}{l}\text { Área } \\
\left(\mathrm{m}^{2}\right)\end{array}$} & \multirow{2}{*}{ Atividade comercial } \\
\hline $\mathbf{X}$ & $\mathbf{Y}$ & & & \\
\hline 201249 & 7562313 & 1 & 70 & Outros segmentos \\
\hline 201334 & 7562298 & 2 & 70 & móveis, eletrodomésticos, equipamentos de informática \\
\hline 201.331 & 7.562 .210 & 3 & 183 & $\begin{array}{l}\text { consultórios médicos, empresas de engenharia, escritórios de arquitetos, advogados, contadores, } \\
\text { bancos, imobiliárias, financeiras }\end{array}$ \\
\hline 201.357 & 7.562 .193 & 4 & 58 & lojas de departamento, artigos de armarinho, vestuário e tecidos, sapatarias e produtos de couro \\
\hline 201.370 & 7.562.194 & 5 & 58 & restaurantes, lanchonetes, bares e cafés \\
\hline 201.379 & 7.562 .194 & 6 & 150 & Outros segmentos \\
\hline 201.388 & 7.562.194 & 7 & 126 & Outros segmentos \\
\hline 201.399 & 7.562 .194 & 8 & 95 & Outros segmentos \\
\hline 201.422 & 7.562 .215 & 9 & 107 & supermercados, mercearias e armazéns \\
\hline 201.436 & 7.562 .215 & 10 & 75 & restaurantes, lanchonetes, bares e cafés \\
\hline 201.456 & 7.562 .216 & 11 & 135 & Outros segmentos \\
\hline 201.470 & 7.562 .217 & 12 & 155 & lojas de departamento, artigos de armarinho, vestuário e tecidos, sapatarias e produtos de couro \\
\hline 201.485 & 7.562 .216 & 13 & 163 & lojas de departamento, artigos de armarinho, vestuário e tecidos, sapatarias e produtos de couro \\
\hline 201.500 & 7.562 .216 & 14 & 145 & lojas de departamento, artigos de armarinho, vestuário e tecidos, sapatarias e produtos de couro \\
\hline 201.423 & 7.562.199 & 15 & 246 & supermercados, mercearias e armazéns \\
\hline 201.423 & 7.562 .197 & 16 & 167 & supermercados, mercearias e armazéns \\
\hline 201.457 & 7.562.199 & 17 & 375 & lojas de departamento, artigos de armarinho, vestuário e tecidos, sapatarias e produtos de couro \\
\hline 201.522 & 7.562 .218 & 18 & 65 & lojas de departamento, artigos de armarinho, vestuário e tecidos, sapatarias e produtos de couro \\
\hline 201.538 & 7.562.217 & 19 & 135 & supermercados, mercearias e armazéns \\
\hline 201.553 & 7.562 .217 & 20 & 118 & lojas de departamento, artigos de armarinho, vestuário e tecidos, sapatarias e produtos de couro \\
\hline 201.569 & 7.562 .217 & 21 & 75 & joalherias, relojoarias e óticas \\
\hline 201.586 & 7.562 .217 & 22 & 125 & lojas de departamento, artigos de armarinho, vestuário e tecidos, sapatarias e produtos de couro \\
\hline 201.602 & 7.562.217 & 23 & 137 & Outros segmentos \\
\hline 201.534 & 7.562 .202 & 24 & 85 & produtos farmacêuticos, perfumaria e cosméticos \\
\hline 201.548 & 7.562 .203 & 25 & 87 & Outros segmentos \\
\hline 201.564 & 7.562 .203 & 26 & 54 & padarias, confeitarias, açougues, peixarias, comércio de frutas, verduras e legumes \\
\hline 201.578 & 7.562 .203 & 27 & 115 & $\begin{array}{l}\text { consultórios médicos, empresas de engenharia, escritórios de arquitetos, advogados, } \\
\text { contadores, bancos, imobiliárias, financeiras }\end{array}$ \\
\hline 201.597 & 7.562 .204 & 28 & 96 & Outros segmentos \\
\hline 201.227 & 7.562 .097 & 29 & 125 & móveis, eletrodomésticos, equipamentos de informática \\
\hline 201.328 & 7.562 .105 & 30 & 57 & Outros segmentos \\
\hline 201.361 & 7.562 .103 & 31 & 125 & $\begin{array}{l}\text { consultórios médicos, empresas de engenharia, escritórios de arquitetos, advogados, } \\
\text { contadores, bancos, imobiliárias, financeiras }\end{array}$ \\
\hline 201.370 & 7.562 .104 & 32 & 73 & $\begin{array}{l}\text { consultórios médicos, empresas de engenharia, escritórios de arquitetos, advogados, } \\
\text { contadores, bancos, imobiliárias, financeiras }\end{array}$ \\
\hline 201.380 & 7.562.104 & 33 & 72 & lojas de departamento, artigos de armarinho, vestuário e tecidos, sapatarias e produtos de couro \\
\hline 201.390 & 7.562 .104 & 34 & 69 & lojas de departamento, artigos de armarinho, vestuário e tecidos, sapatarias e produtos de couro \\
\hline 201.398 & 7.562 .104 & 35 & 65 & lojas de departamento, artigos de armarinho, vestuário e tecidos, sapatarias e produtos de couro \\
\hline 201.408 & 7.562 .105 & 36 & 96 & lojas de departamento, artigos de armarinho, vestuário e tecidos, sapatarias e produtos de couro \\
\hline 201.332 & 7.562 .084 & 37 & 89 & lojas de departamento, artigos de armarinho, vestuário e tecidos, sapatarias e produtos de couro \\
\hline 201.348 & 7.562 .083 & 38 & 127 & supermercados, mercearias e armazéns \\
\hline 201.362 & 7.562 .084 & 39 & 355 & supermercados, mercearias e armazéns \\
\hline 201.377 & 7.562 .083 & 40 & 59 & móveis, eletrodomésticos, equipamentos de informática \\
\hline 201.390 & 7.562 .082 & 41 & 57 & produtos farmacêuticos, perfumaria e cosméticos \\
\hline 201.405 & 7.562 .084 & 42 & 56 & Outros segmentos \\
\hline 201.436 & 7.562 .107 & 43 & 23 & restaurantes, lanchonetes, bares e cafés \\
\hline 201.443 & 7.562 .106 & 44 & 39 & lojas de departamento, artigos de armarinho, vestuário e tecidos, sapatarias e produtos de couro \\
\hline 201.450 & 7.562 .107 & 45 & 48 & lojas de departamento, artigos de armarinho, vestuário e tecidos, sapatarias e produtos de couro \\
\hline 201.458 & 7.562 .106 & 46 & 45 & joalherias, relojoarias e óticas \\
\hline 201.466 & 7.562.107 & 47 & 71 & produtos farmacêuticos, perfumaria e cosméticos \\
\hline 201.474 & 7.562 .108 & 48 & 78 & lojas de departamento, artigos de armarinho, vestuário e tecidos, sapatarias e produtos de couro \\
\hline 201.490 & 7.562 .109 & 49 & 87 & lojas de departamento, artigos de armarinho, vestuário e tecidos, sapatarias e produtos de couro \\
\hline 201.497 & 7.562 .109 & 50 & 62 & lojas de departamento, artigos de armarinho, vestuário e tecidos, sapatarias e produtos de couro \\
\hline 201.507 & 7.562 .109 & 51 & 87 & lojas de departamento, artigos de armarinho, vestuário e tecidos, sapatarias e produtos de couro \\
\hline 201.428 & 7.562 .089 & 52 & 157 & lojas de departamento, artigos de armarinho, vestuário e tecidos, sapatarias e produtos de couro \\
\hline 201.435 & 7.562 .089 & 53 & 73 & lojas de departamento, artigos de armarinho, vestuário e tecidos, sapatarias e produtos de couro \\
\hline 201.436 & 7.562 .089 & 54 & 74 & móveis, eletrodomésticos, equipamentos de informática \\
\hline 201.443 & 7.562 .089 & 55 & 64 & lojas de departamento, artigos de armarinho, vestuário e tecidos, sapatarias e produtos de couro \\
\hline 201.460 & 7.562 .089 & 56 & 66 & lojas de departamento, artigos de armarinho, vestuário e tecidos, sapatarias e produtos de couro \\
\hline 201.474 & 7.562 .089 & 57 & 186 & lojas de departamento, artigos de armarinho, vestuário e tecidos, sapatarias e produtos de couro \\
\hline 201.482 & 7.562 .090 & 58 & 62 & lojas de departamento, artigos de armarinho, vestuário e tecidos, sapatarias e produtos de couro \\
\hline 201.490 & 7.562 .090 & 59 & 65 & Outros segmentos \\
\hline 201.502 & 7.562 .091 & 60 & 58 & produtos farmacêuticos, perfumaria e cosméticos \\
\hline 201.525 & 7.562 .097 & 61 & 54 & lojas de departamento, artigos de armarinho, vestuário e tecidos, sapatarias e produtos de couro \\
\hline 201.534 & 7.562 .097 & 62 & 118 & Outros segmentos \\
\hline 201.547 & 7.562 .096 & 63 & 220 & lojas de departamento, artigos de armarinho, vestuário e tecidos, sapatarias e produtos de couro \\
\hline 201.560 & 7.562 .096 & 64 & 48 & lojas de departamento, artigos de armarinho, vestuário e tecidos, sapatarias e produtos de couro \\
\hline 201.438 & 7.562 .009 & 65 & 72 & Outros segmentos \\
\hline 201.446 & 7.561 .985 & 66 & 75 & lojas de departamento, artigos de armarinho, vestuário e tecidos, sapatarias e produtos de couro \\
\hline 201.456 & 7.562 .009 & 67 & 64 & joalherias, relojoarias e óticas \\
\hline 201.464 & 7.561 .985 & 68 & 75 & produtos farmacêuticos, perfumaria e cosméticos \\
\hline 201.471 & 7.562 .009 & 69 & 82 & produtos farmacêuticos, perfumaria e cosméticos \\
\hline 201.480 & 7.561 .984 & 70 & 75 & lojas de departamento, artigos de armarinho, vestuário e tecidos, sapatarias e produtos de couro \\
\hline 201.485 & 7.562 .009 & 71 & 74 & lojas de departamento, artigos de armarinho, vestuário e tecidos, sapatarias e produtos de couro \\
\hline 201.494 & 7.561 .984 & 72 & 73 & produtos farmacêuticos, perfumaria e cosméticos \\
\hline
\end{tabular}




\begin{tabular}{|c|c|c|c|c|}
\hline \multicolumn{2}{|c|}{ Coordenadas UTM $\left(23^{\circ} \mathrm{S}\right)$} & \multirow[b]{2}{*}{ ID } & \multirow{2}{*}{$\begin{array}{l}\text { Área } \\
\left(m^{2}\right)\end{array}$} & \multirow{2}{*}{ Atividade comercial } \\
\hline & & & & \\
\hline 201.499 & 7.562.009 & 73 & 77 & lojas de departamento, artigos de armarinho, vestuário e tecidos, sapatarias e produtos de couro \\
\hline 201.508 & 7.561 .984 & 74 & 65 & lojas de departamento, artigos de armarinho, vestuário e tecidos, sapatarias e produtos de couro \\
\hline 201.512 & 7.562 .010 & 75 & 58 & lojas de departamento, artigos de armarinho, vestuário e tecidos, sapatarias e produtos de couro \\
\hline 201.531 & 7.562 .011 & 76 & 59 & $\begin{array}{l}\text { consultórios médicos, empresas de engenharia, escritórios de arquitetos, advogados, } \\
\text { contadores, bancos, imobiliárias, financeiras }\end{array}$ \\
\hline 201.530 & 7.561 .984 & 77 & 64 & lojas de departamento, artigos de armarinho, vestuário e tecidos, sapatarias e produtos de couro \\
\hline 201.546 & 7.562 .011 & 78 & 87 & lojas de departamento, artigos de armarinho, vestuário e tecidos, sapatarias e produtos de couro \\
\hline 201.543 & 7.561 .984 & 79 & 120 & Outros segmentos \\
\hline 201.560 & 7.562 .011 & 80 & 75 & Outros segmentos \\
\hline 201.559 & 7.561 .984 & 81 & 85 & lojas de departamento, artigos de armarinho, vestuário e tecidos, sapatarias e produtos de couro \\
\hline 201.580 & 7.562 .012 & 82 & 88 & Outros segmentos \\
\hline 201.579 & 7.561 .984 & 83 & 89 & lojas de departamento, artigos de armarinho, vestuário e tecidos, sapatarias e produtos de couro \\
\hline 201.597 & 7.562 .013 & 84 & 63 & lojas de departamento, artigos de armarinho, vestuário e tecidos, sapatarias e produtos de couro \\
\hline 201.596 & 7.561 .985 & 85 & 62 & lojas de departamento, artigos de armarinho, vestuário e tecidos, sapatarias e produtos de couro \\
\hline 201.612 & 7.562.018 & 86 & 53 & $\begin{array}{l}\text { consultórios médicos, empresas de engenharia, escritórios de arquitetos, advogados, } \\
\text { contadores, bancos, imobiliárias, financeiras }\end{array}$ \\
\hline 201.294 & 7.562.296 & 87 & 193 & padarias, confeitarias, açougues , peixarias, comércio de frutas, verduras e legumes \\
\hline 201.295 & 7.562.283 & 88 & 126 & Outros segmentos \\
\hline 201.296 & 7.562.252 & 89 & 76 & produtos farmacêuticos, perfumaria e cosméticos \\
\hline 201.310 & 7.562 .222 & 90 & 56 & $\begin{array}{l}\text { consultórios médicos, empresas de engenharia, escritórios de arquitetos, advogados, } \\
\text { contadores, bancos, imobiliárias, financeiras }\end{array}$ \\
\hline 201.301 & 7.562 .188 & 91 & 30 & Outros segmentos \\
\hline 201.302 & 7.562.177 & 92 & 31 & restaurantes, lanchonetes, bares e cafés \\
\hline 201.302 & 7.562 .168 & 93 & 32 & $\begin{array}{l}\text { consultórios médicos, empresas de engenharia, escritórios de arquitetos, advogados, } \\
\text { contadores, bancos, imobiliárias, financeiras }\end{array}$ \\
\hline 201.303 & 7.562 .157 & 94 & 33 & $\begin{array}{l}\text { consultórios médicos, empresas de engenharia, escritórios de arquitetos, advogados, } \\
\text { contadores, bancos, imobiliárias, financeiras }\end{array}$ \\
\hline 201.417 & 7.562 .196 & 95 & 64 & lojas de departamento, artigos de armarinho, vestuário e tecidos, sapatarias e produtos de couro \\
\hline 201.422 & 7.562 .156 & 96 & 63 & restaurantes, lanchonetes, bares e cafés \\
\hline 201.406 & 7.562.173 & 97 & 103 & joalherias, relojoarias e óticas \\
\hline 201.407 & 7.562 .159 & 98 & 35 & joalherias, relojoarias e óticas \\
\hline 201.424 & 7.562 .130 & 99 & 210 & joalherias, relojoarias e óticas \\
\hline 201.406 & 7.562 .125 & 100 & 102 & lojas de departamento, artigos de armarinho, vestuário e tecidos, sapatarias e produtos de couro \\
\hline 201.425 & 7.562 .115 & 101 & 73 & lojas de departamento, artigos de armarinho, vestuário e tecidos, sapatarias e produtos de couro \\
\hline 201.409 & 7.562 .076 & 102 & 85 & Outros segmentos \\
\hline 201.410 & 7.562 .065 & 103 & 95 & lojas de departamento, artigos de armarinho, vestuário e tecidos, sapatarias e produtos de couro \\
\hline 201.410 & 7.562 .051 & 104 & 78 & Outros segmentos \\
\hline 201.410 & 7.562 .032 & 105 & 98 & lojas de departamento, artigos de armarinho, vestuário e tecidos, sapatarias e produtos de couro \\
\hline 201.425 & 7.562 .084 & 106 & 79 & lojas de departamento, artigos de armarinho, vestuário e tecidos, sapatarias e produtos de couro \\
\hline 201.425 & 7.562 .082 & 107 & 105 & lojas de departamento, artigos de armarinho, vestuário e tecidos, sapatarias e produtos de couro \\
\hline 201.427 & 7.562 .052 & 108 & 88 & lojas de departamento, artigos de armarinho, vestuário e tecidos, sapatarias e produtos de couro \\
\hline 201.512 & 7.561.962 & 109 & 221 & produtos farmacêuticos, perfumaria e cosméticos \\
\hline 201.532 & 7.561 .962 & 110 & 317 & lojas de departamento, artigos de armarinho, vestuário e tecidos, sapatarias e produtos de couro \\
\hline 201.512 & 7.562 .021 & 111 & 450 & móveis, eletrodomésticos, equipamentos de informática \\
\hline 201.530 & 7.562 .023 & 112 & 88 & lojas de departamento, artigos de armarinho, vestuário e tecidos, sapatarias e produtos de couro \\
\hline 201.530 & 7.562 .040 & 113 & 160 & lojas de departamento, artigos de armarinho, vestuário e tecidos, sapatarias e produtos de couro \\
\hline 201.509 & 7.562 .058 & 114 & 152 & lojas de departamento, artigos de armarinho, vestuário e tecidos, sapatarias e produtos de couro \\
\hline 201.509 & 7.562 .041 & 115 & 394 & lojas de departamento, artigos de armarinho, vestuário e tecidos, sapatarias e produtos de couro \\
\hline 201.629 & 7.562.231 & 116 & 84 & Outros segmentos \\
\hline 201.629 & 7.562.229 & 117 & 55 & Outros segmentos \\
\hline 201.630 & 7.562.242 & 118 & 120 & $\begin{array}{l}\text { consultórios médicos, empresas de engenharia, escritórios de arquitetos, advogados, } \\
\text { contadores, bancos, imobiliárias, financeiras }\end{array}$ \\
\hline 201.630 & 7.562.152 & 119 & 125 & restaurantes, lanchonetes, bares e cafés \\
\hline 201.631 & 7.562 .179 & 120 & 125 & móveis, eletrodomésticos, equipamentos de informática \\
\hline 201.631 & 7.562 .172 & 121 & 125 & Outros segmentos \\
\hline 201.631 & 7.562 .161 & 122 & 125 & lojas de departamento, artigos de armarinho, vestuário e tecidos, sapatarias e produtos de couro \\
\hline 201.635 & 7.562.099 & 123 & 175 & móveis, eletrodomésticos, equipamentos de informática \\
\hline 201.636 & 7.562.089 & 124 & 83 & produtos farmacêuticos, perfumaria e cosméticos \\
\hline 201.635 & 7.562.076 & 125 & 111 & móveis, eletrodomésticos, equipamentos de informática \\
\hline 201.635 & 7.562 .066 & 126 & 174 & lojas de departamento, artigos de armarinho, vestuário e tecidos, sapatarias e produtos de couro \\
\hline 201.637 & 7.562 .042 & 127 & 145 & lojas de departamento, artigos de armarinho, vestuário e tecidos, sapatarias e produtos de couro \\
\hline 201.613 & 7.562 .100 & 128 & 49 & lojas de departamento, artigos de armarinho, vestuário e tecidos, sapatarias e produtos de couro \\
\hline 201.613 & 7.562 .091 & 129 & 137 & joalherias, relojoarias e óticas \\
\hline 201.614 & 7.562 .081 & 130 & 50 & Outros segmentos \\
\hline 201.615 & 7.562 .071 & 131 & 65 & lojas de departamento, artigos de armarinho, vestuário e tecidos, sapatarias e produtos de couro \\
\hline 201.616 & 7.562 .062 & 132 & 72 & produtos farmacêuticos, perfumaria e cosméticos \\
\hline 201.334 & 7.562 .172 & 133 & 172 & padarias, confeitarias, açougues, peixarias, comércio de frutas, verduras e legumes \\
\hline 201.346 & 7.562 .161 & 134 & 75 & Outros segmentos \\
\hline 201.357 & 7.562.153 & 135 & 62 & consultórios médicos, empresas de engenharia, escritórios de arquitetos, advogados \\
\hline 201.374 & 7.562 .150 & 136 & 75 & joalherias, relojoarias e óticas \\
\hline 201.394 & 7.562 .150 & 137 & 79 & Outros segmentos \\
\hline 201.340 & 7.562 .134 & 138 & 75 & lojas de departamento, artigos de armarinho, vestuário e tecidos, sapatarias e produtos de couro \\
\hline 201.350 & 7.562 .130 & 139 & 77 & joalherias, relojoarias e óticas \\
\hline 201.358 & 7.562.128 & 140 & 89 & produtos farmacêuticos, perfumaria e cosméticos \\
\hline 201.374 & 7.562.127 & 141 & 95 & lojas de departamento, artigos de armarinho, vestuário e tecidos, sapatarias e produtos de couro \\
\hline 201.383 & 7.562.127 & 142 & 47 & produtos farmacêuticos, perfumaria e cosméticos \\
\hline 201.391 & 7.562.128 & 143 & 94 & lojas de departamento, artigos de armarinho, vestuário e tecidos, sapatarias e produtos de couro \\
\hline 201.401 & 7.562 .128 & 144 & 116 & lojas de departamento, artigos de armarinho, vestuário e tecidos, sapatarias e produtos de couro \\
\hline 201.436 & 7.562.129 & 145 & 85 & lojas de departamento, artigos de armarinho, vestuário e tecidos, sapatarias e produtos de couro \\
\hline 201.445 & 7.562.129 & 146 & 65 & lojas de departamento, artigos de armarinho, vestuário e tecidos, sapatarias e produtos de couro \\
\hline 201.460 & 7.562.130 & 147 & 120 & lojas de departamento, artigos de armarinho, vestuário e tecidos, sapatarias e produtos de couro \\
\hline 201.474 & 7.562 .129 & 148 & 136 & lojas de departamento, artigos de armarinho, vestuário e tecidos, sapatarias e produtos de couro \\
\hline 201.438 & 7.562 .151 & 149 & 270 & supermercados, mercearias e armazéns \\
\hline 201.457 & 7.562 .150 & 150 & 180 & lojas de departamento, artigos de armarinho, vestuário e tecidos, sapatarias e produtos de couro \\
\hline
\end{tabular}




\section{ANEXO A}

Localização dos barramentos propostos pelo Plano Diretor de Drenagem de São Carlos - SP e utilizados no cenário "Plano Diretor com Medidas Estruturais"

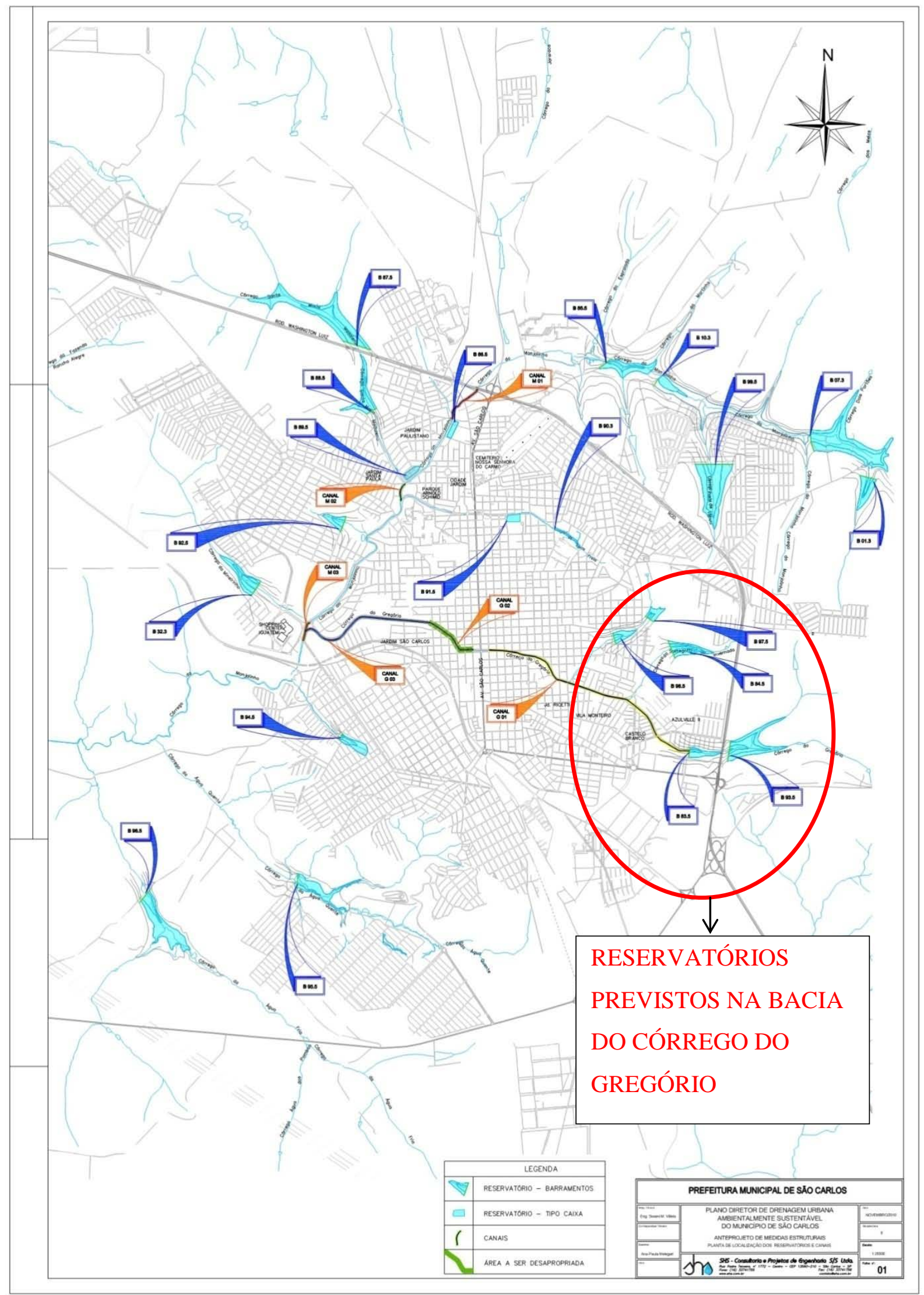




\section{ANEXO B}

Curva cota-área e cota-volume dos reservatórios previstos na bacia do Córrego do Gregório (anexo A)

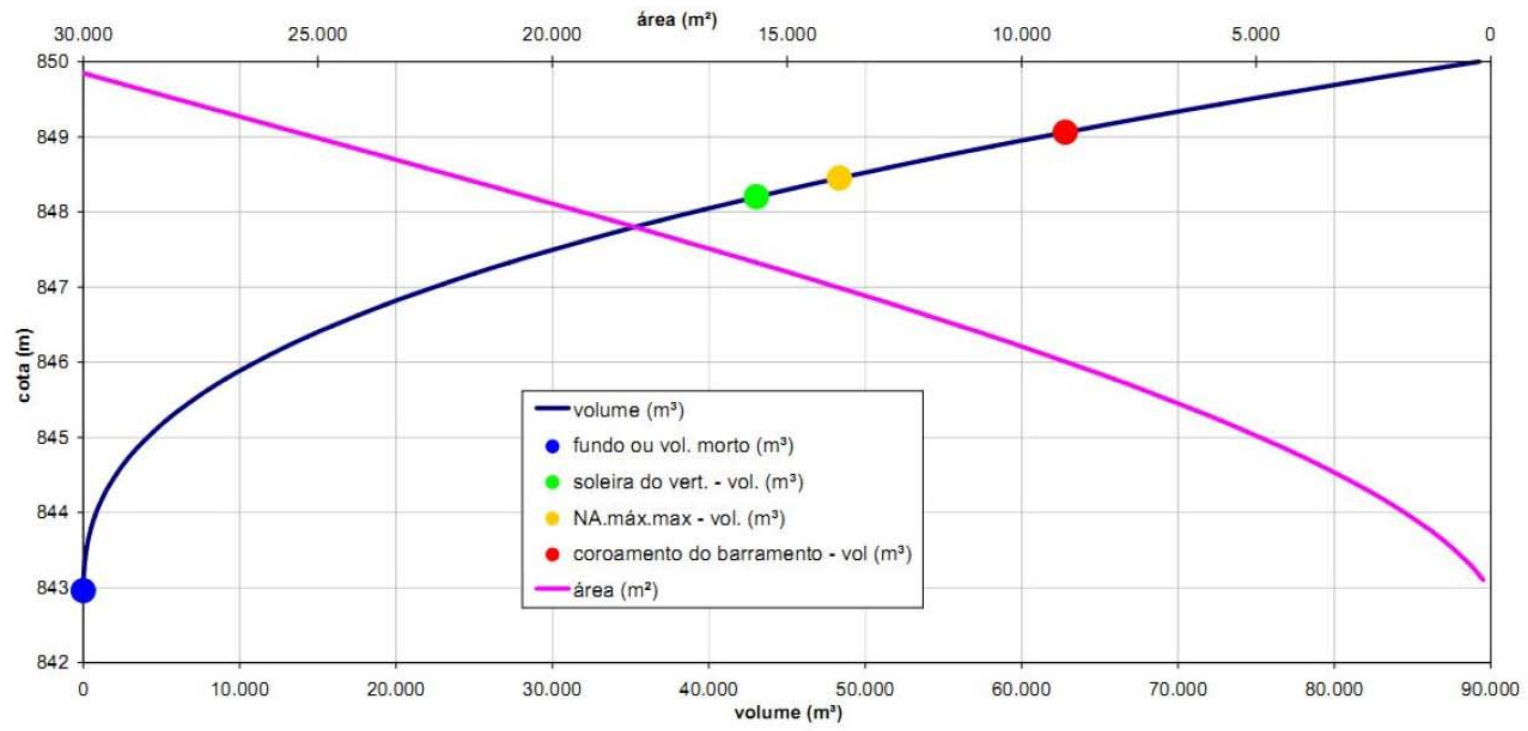

Curva cota-área e cota-volume do reservatório G2 B 83.5

Fonte: PMSC (2011)

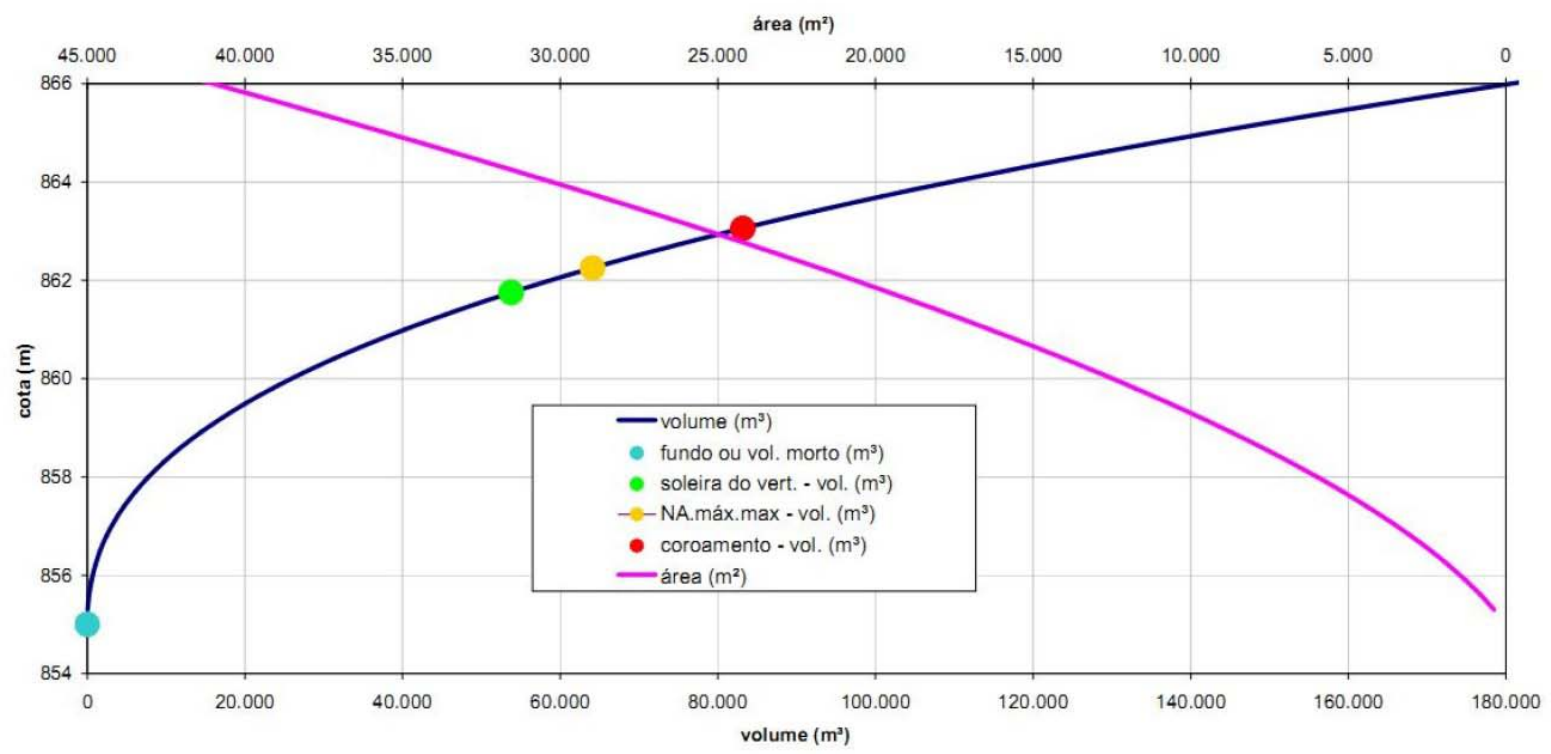

Curva cota-área e cota-volume do reservatório S1 B 84.5

Fonte: PMSC (2011) 


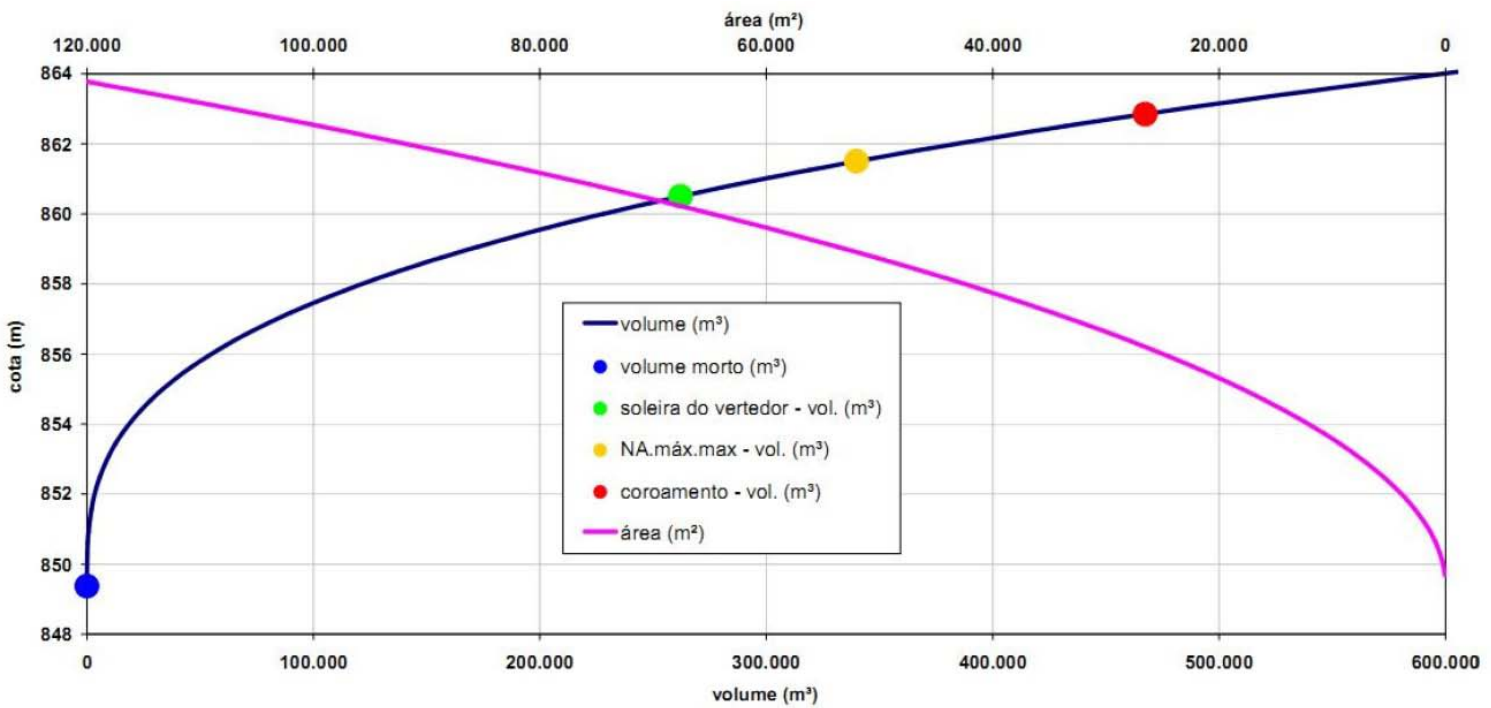

Curva cota-área e cota-volume do reservatório G1 B 93.5

Fonte: PMSC (2011)

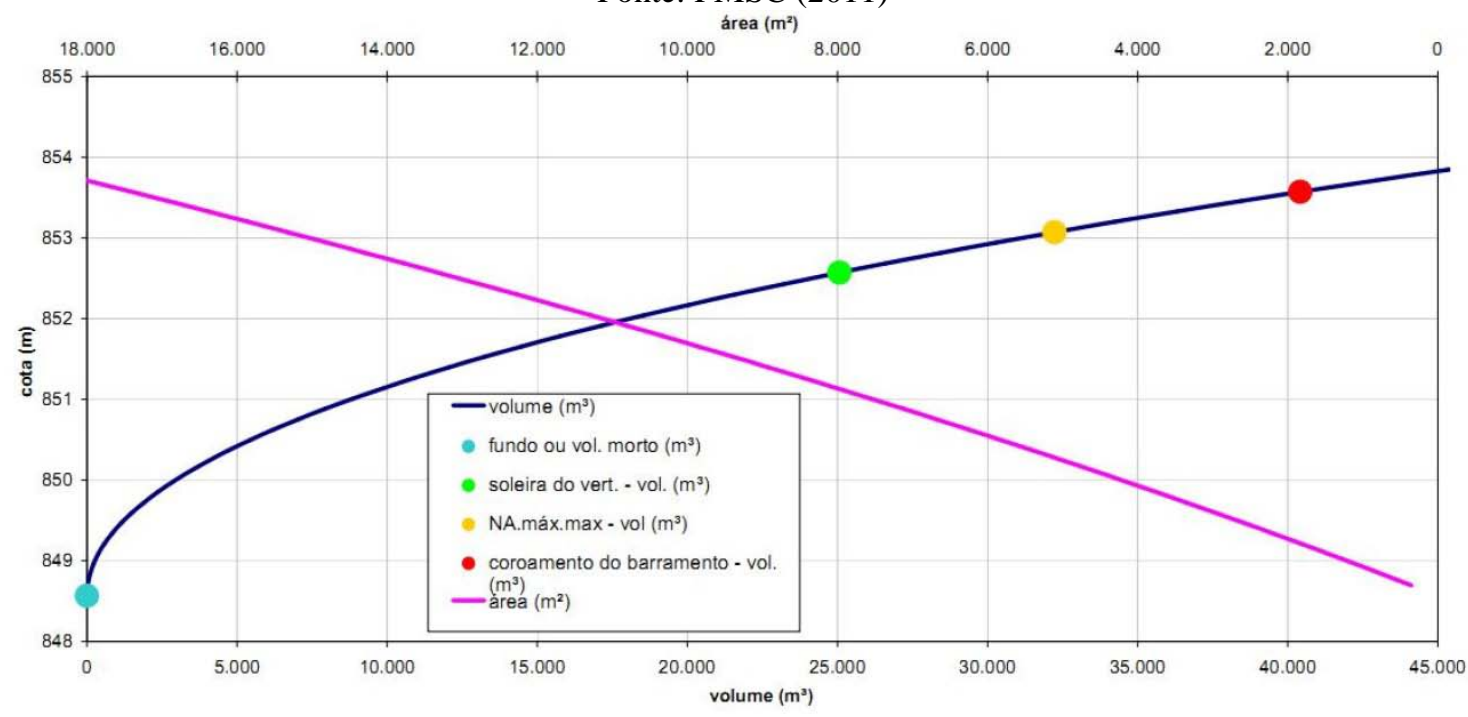

Curva cota-área e cota-volume do reservatório La1 B 97.5

Fonte: PMSC (2011)

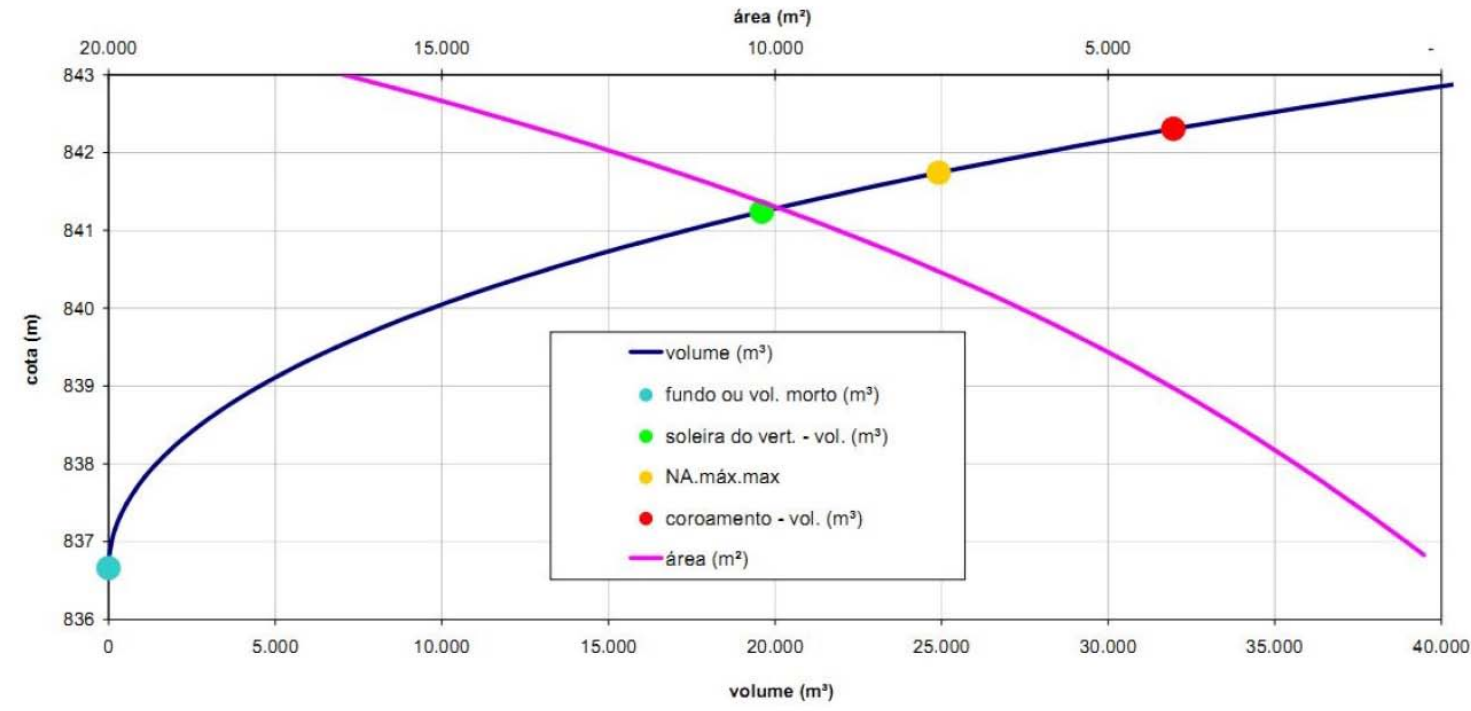

Curva cota-área e cota-volume do reservatório La2 B 98.5

Fonte: PMSC (2011) 


\section{ANEXO C}

Curva Profundidade-Dano do setor de comércio e serviços do município de Itajubá - MG

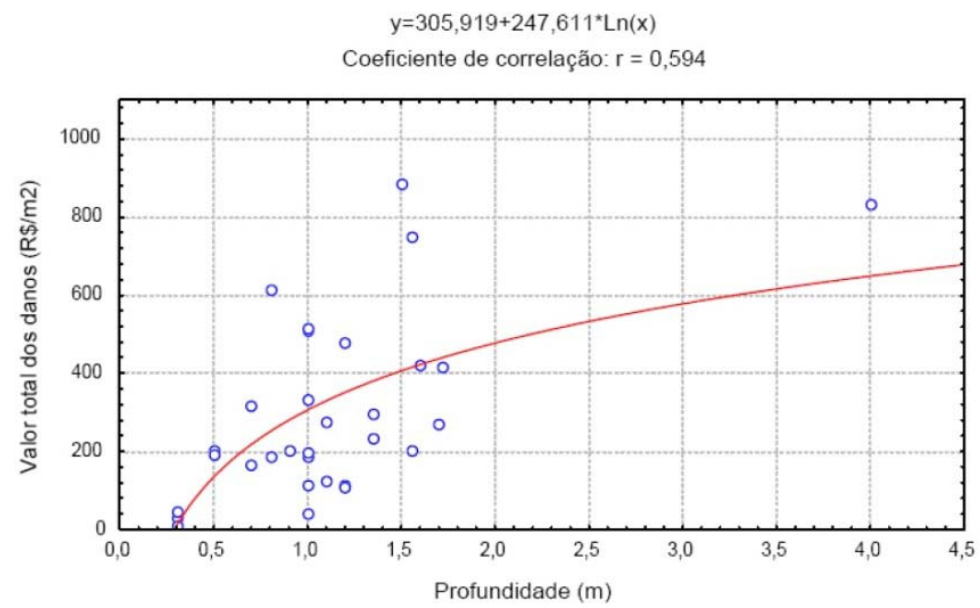

Curva Profundidade-Dano do setor de comércio de lojas de departamento, artigos de armarinho, vestuário e tecidos, sapatarias e produtos de couro Fonte: Milograna (2009)

$y=238,37+167,267^{*} \operatorname{Ln}(x)$

Coeficiente de Correlação: $r=0,658$

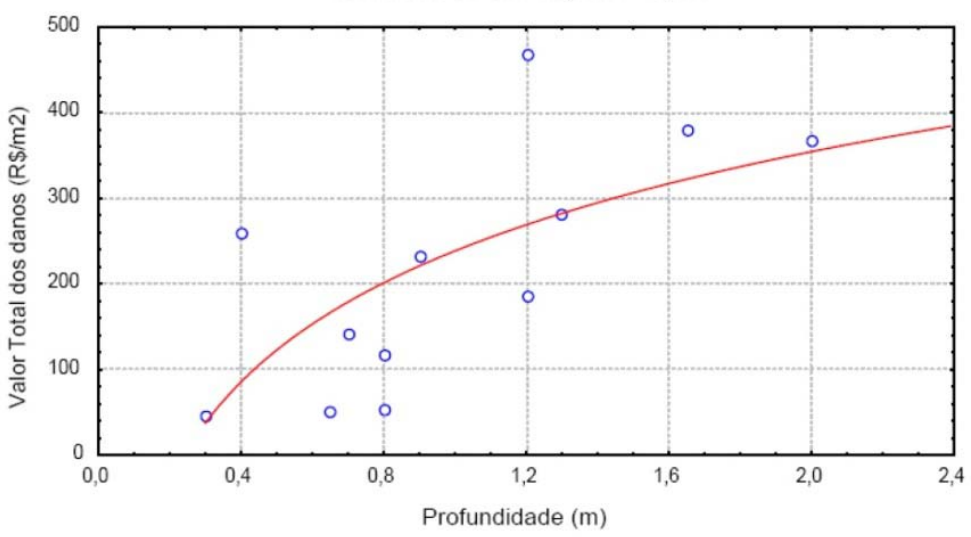

Curva Profundidade-Dano do setor de comércio de mercados e lojas de departamento Fonte: Milograna (2009)

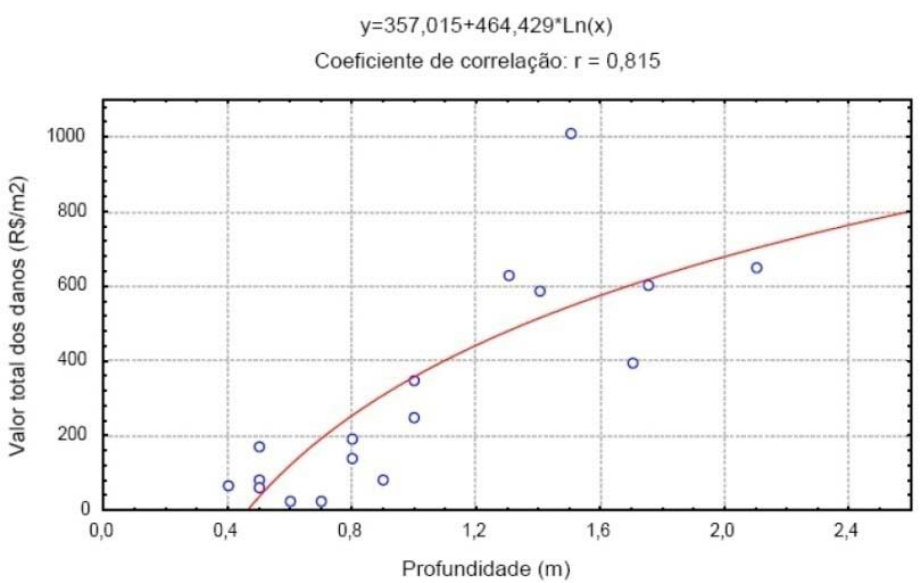

Curva Profundidade-Dano do setor de comércio de móveis, eletrodomésticos, equipamentos de informática 
Fonte: Milograna (2009)

$y=319,796+286,196^{*} \operatorname{Ln}(x)$

Coeficiente de correlação: $r=0,803$

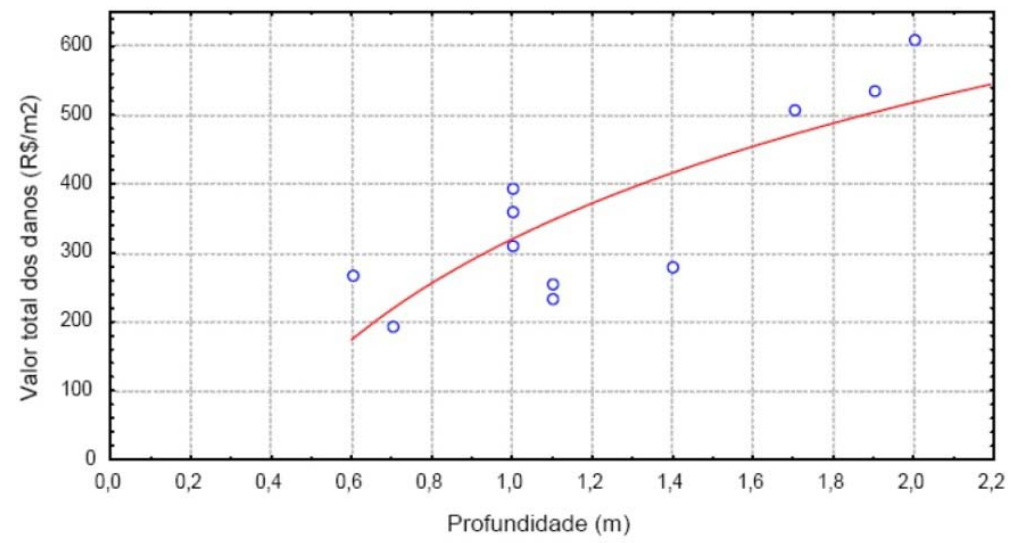

Curva Profundidade-Dano do setor de comércio de produtos farmacêuticos, perfumaria e cosméticos Fonte: Milograna (2009)

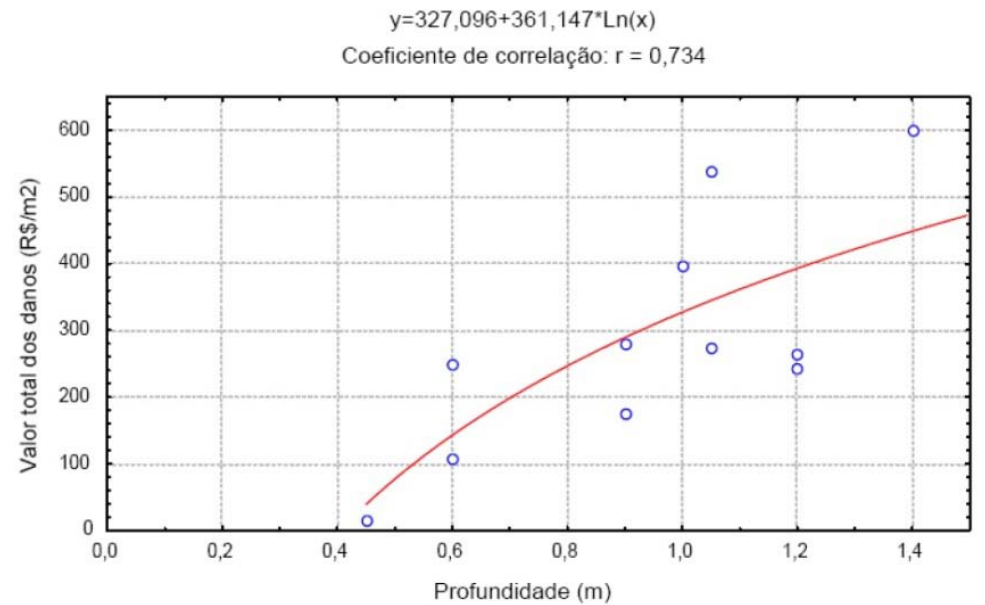

Curva Profundidade-Dano do setor de comércio de joalherias, relojoarias e óticas Fonte: Milograna (2009)

$y=62,979+66,845^{\circ} \operatorname{Ln}(x)$

Coeficiente de correlação: $r=0,543$

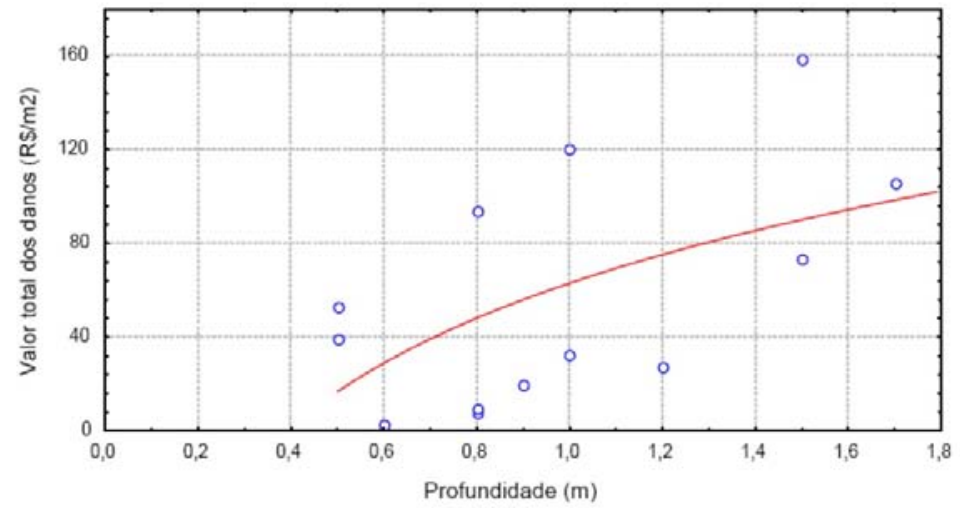

Curva Profundidade-Dano do setor de comércio Restaurantes, lanchonetes, bares e cafés Fonte: Milograna (2009) 
$y=96,339+21,618^{*} \operatorname{Ln}(x)$

Coeficiente de correlação: $r=0,40$

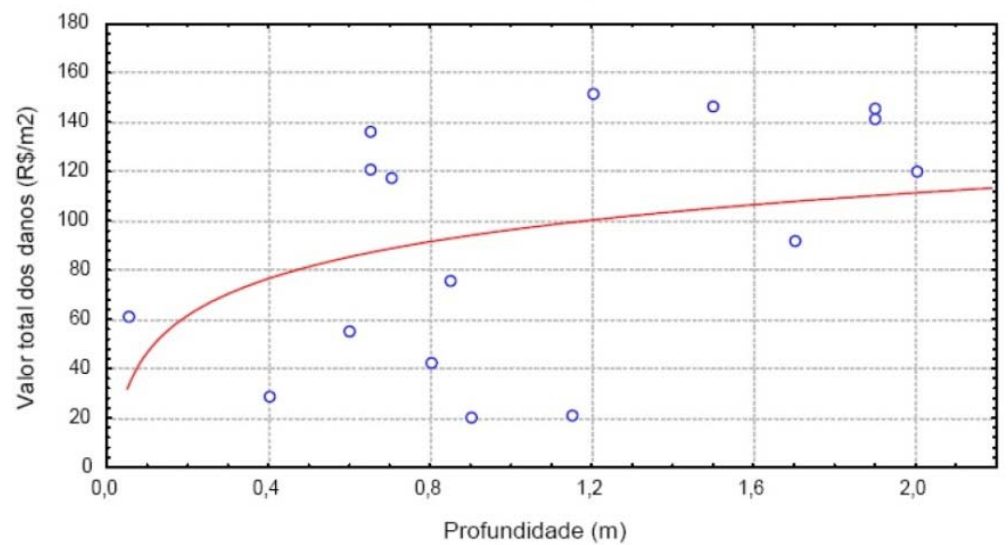

Curva Profundidade-Dano do setor de serviços de Escritórios e consultoria Fonte: Milograna (2009) 
ANEXO D

DELIMITAÇÃO DAS ZONAS DO PLANO DE DIRETOR DE SÃO CARLOS (PMSC, 2005) 


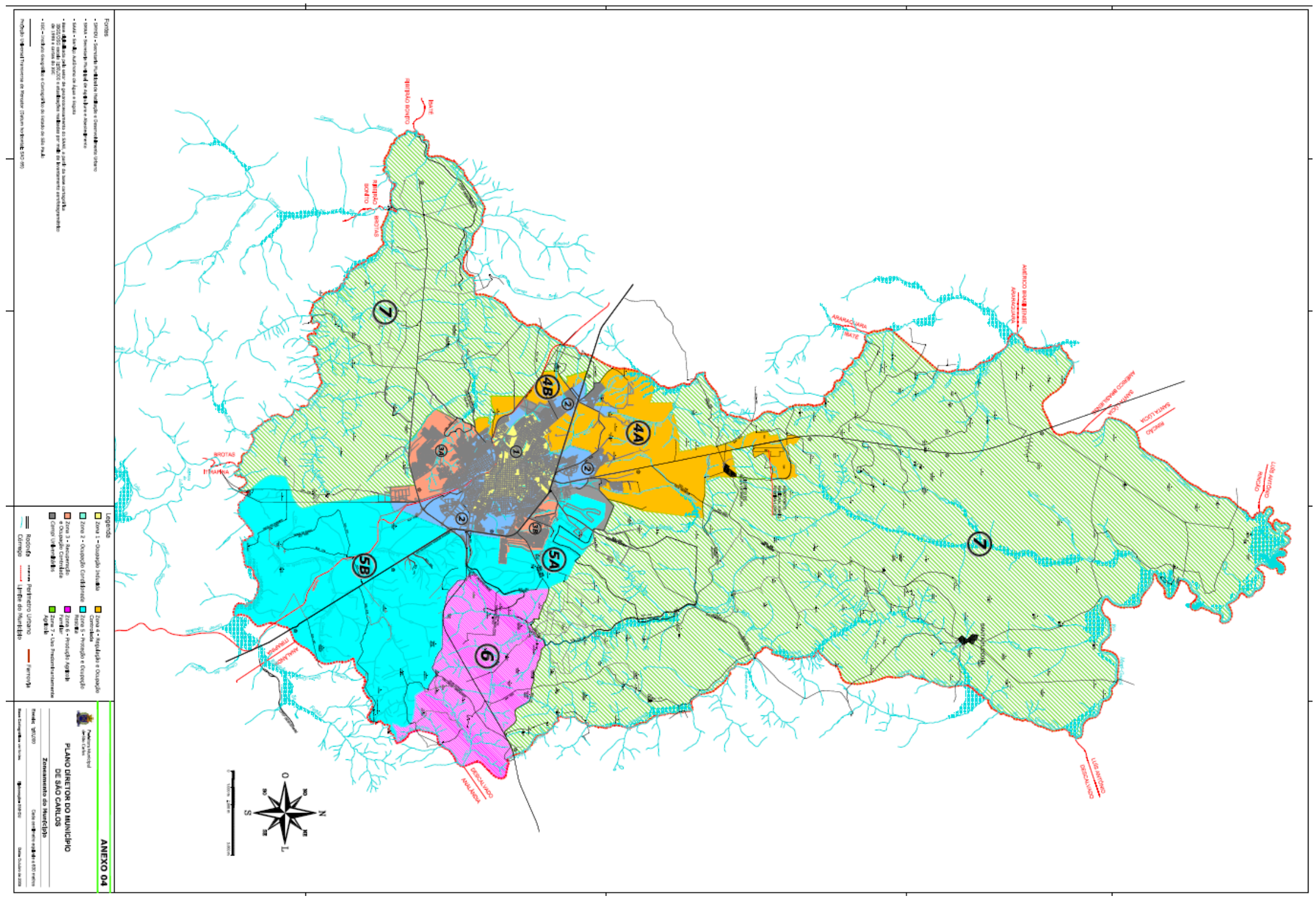

